Nevada

Environmental

Restoration

Project

\title{
Double Tracks Test Site Characterization Report
}

RECEIVED AUG 051997

OSTI

May 1996

\section{MASTER}

\section{Environmental Restoration}

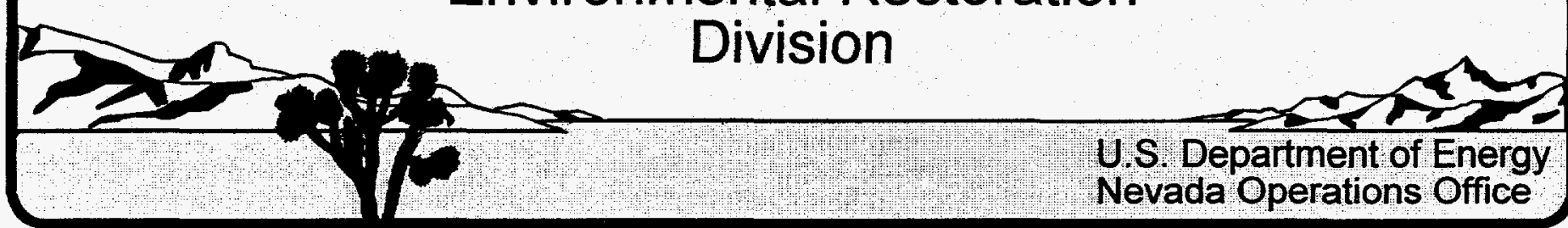





\section{DOUBLE TRACKS TEST SITE CHARACTERIZATION REPORT}

DOE Nevada Operations Office

Las Vegas, Nevada

May 1996 



\section{DISCLAMMER}

Portions of this document may be illegible in electronic image products. Images are produced from the best available original document. 

DOUBLE TRACKS TEST SITE CHARACTERIZATION REPORT

Submitted by:

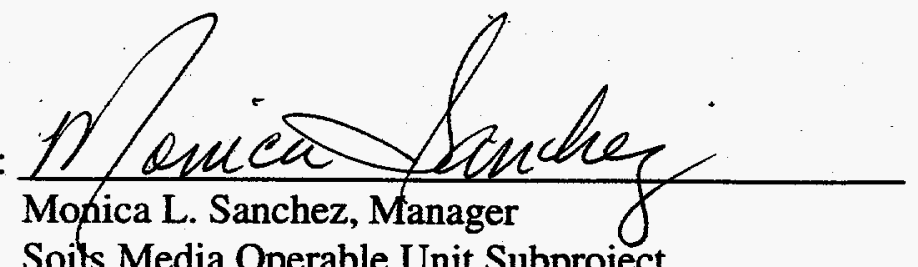

Soils Media Operable Unit Subproject

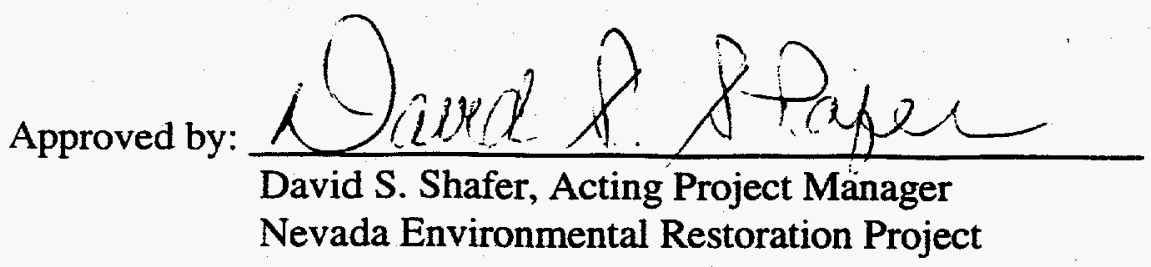

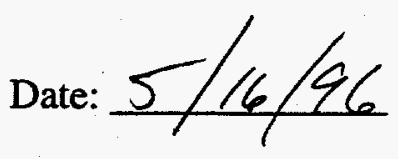

Date: $5 / 16 / \%$ 



\section{Table of Contents}

List of Figures $\ldots \ldots \ldots \ldots \ldots \ldots \ldots \ldots \ldots \ldots \ldots \ldots \ldots \ldots \ldots \ldots \ldots \ldots \ldots$

List of Tables $\ldots \ldots \ldots \ldots \ldots \ldots \ldots \ldots \ldots \ldots \ldots \ldots \ldots \ldots \ldots \ldots \ldots$ iv

List of Acronyms and Abbreviations $\ldots \ldots \ldots \ldots \ldots \ldots \ldots \ldots \ldots \ldots \ldots \ldots \ldots \ldots$

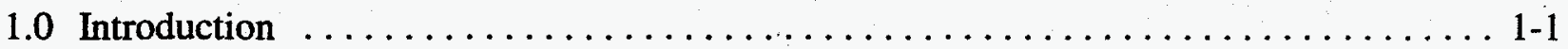

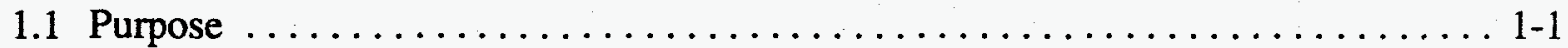

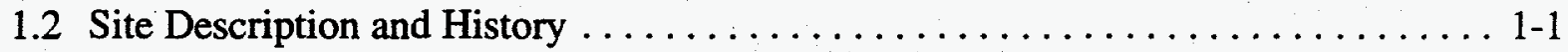

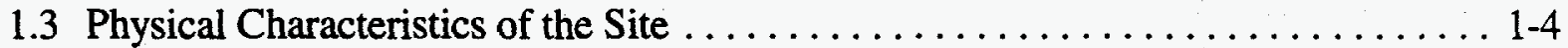

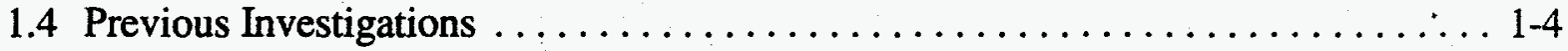

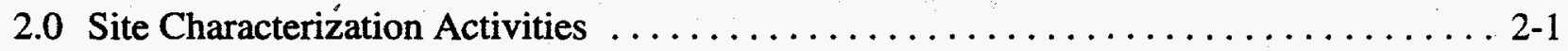

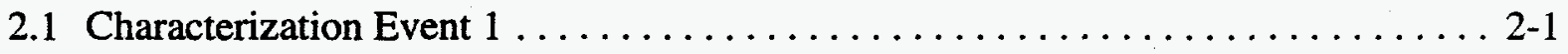

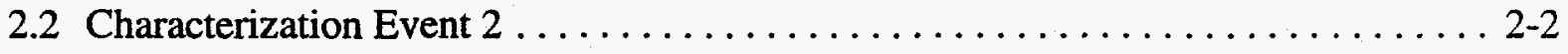

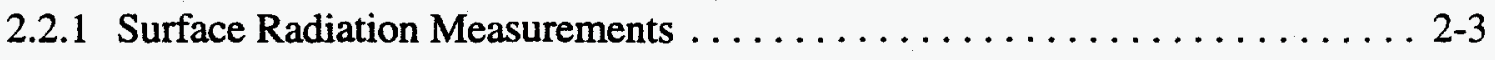

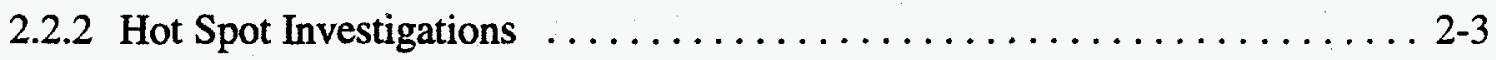

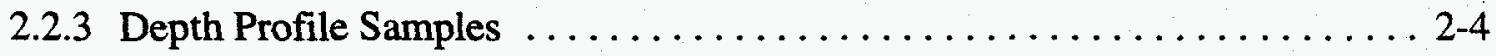

2.2.4 Passive Alpha Detector Measurements $\ldots \ldots \ldots \ldots \ldots \ldots \ldots \ldots \ldots \ldots \ldots$

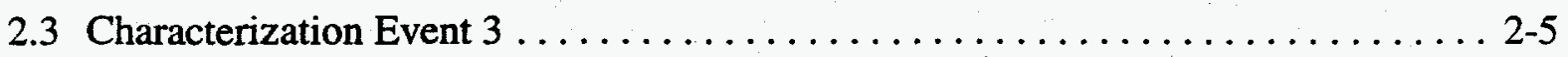

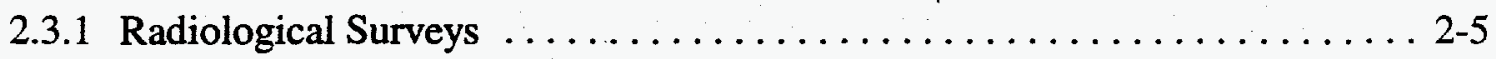

2.3.1.1 All-Terrain Vehicle-Mounted FIDLER Survey $\ldots \ldots \ldots \ldots \ldots 2-5$

2.3.1.2 Suburban-mounted Sodium-Iodide Detector Survey ........ . 2-5

2.3.1.3 Suburban Mast-Mounted HPGe Detector Survey . . . . . . . . . 2-6

2.3.1.4 Jeep-mounted Scintillation Detector Survey . . . . . . . . . . 2-6

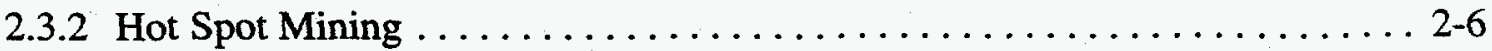

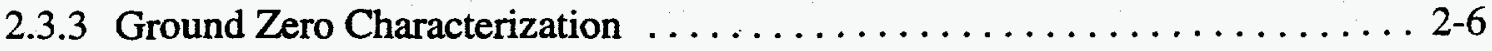

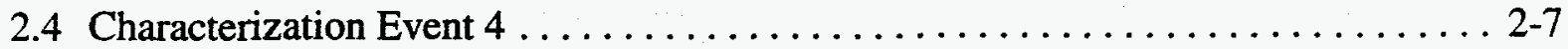

3.0 Nature and Extent of Soil Contamination $\ldots \ldots \ldots \ldots \ldots \ldots \ldots \ldots \ldots \ldots \ldots \ldots \ldots \ldots$

3.1 Radiological Constituents . . . . . . . . . . . . . . . . . . . 3-1

3.1.1 Identification of Radiological Constituents of Concern . . . . . . . . . 3-1

3.1.2 Plutonium/Americium Isotopic Ratio $\ldots \ldots \ldots \ldots \ldots \ldots \ldots \ldots \ldots \ldots \ldots$ 
3.1.3 Radiological Hot Spots . . . . . . . . . . . . . . . . . . . .

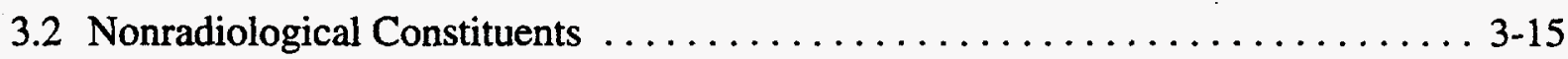

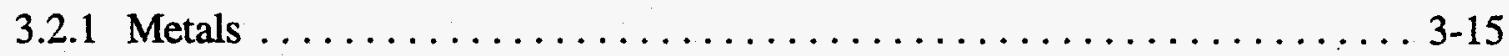

3.2.2 Toxicity Characteristic Leaching Procedure Results $\ldots \ldots \ldots \ldots \ldots \ldots$ 3-17

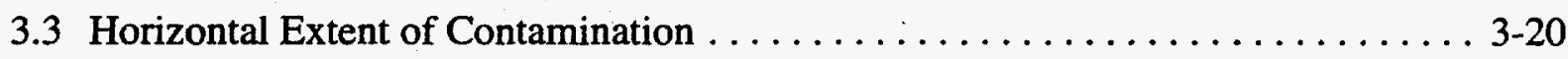

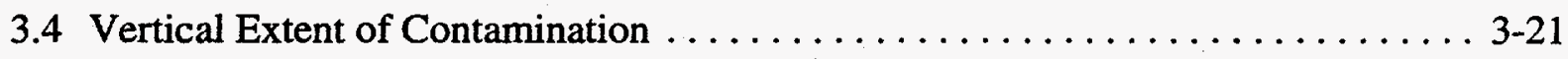

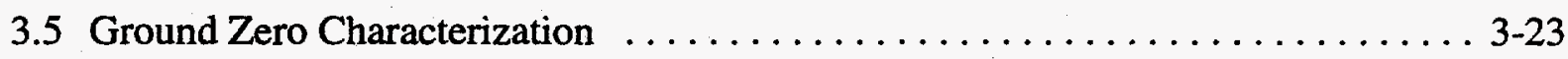

3.6 Soil Particle-size and Volume Reduction Testing $\ldots \ldots \ldots \ldots \ldots \ldots \ldots \ldots \ldots \ldots \ldots \ldots \ldots$

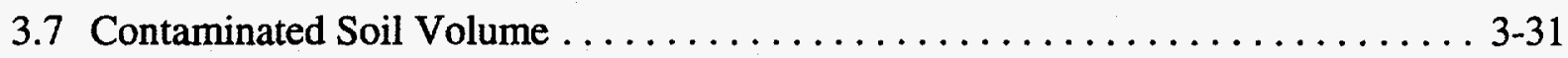

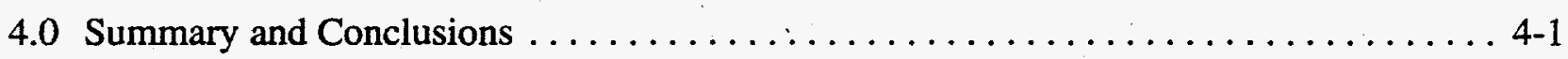

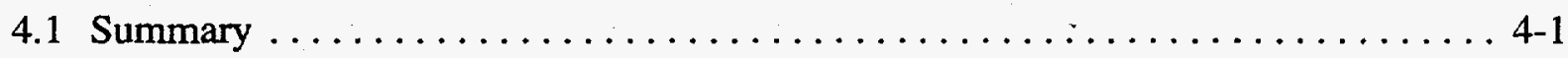

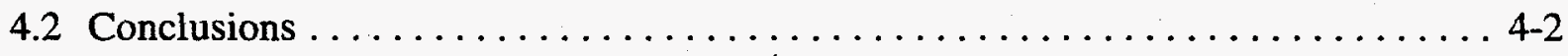

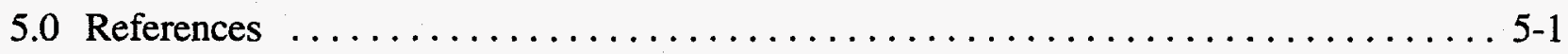

Appendix A - IT Field Sampling Instructions $\ldots \ldots \ldots \ldots \ldots \ldots \ldots \ldots \ldots \ldots \ldots \ldots \ldots \ldots \ldots \ldots$

Appendix B - EG\&G Remote-Sensing Mission Plans $\ldots \ldots \ldots \ldots \ldots \ldots \ldots \ldots \ldots$ B-1

Appendix C - Soil Sample Analytical Data $\ldots \ldots \ldots \ldots \ldots \ldots \ldots \ldots \ldots \ldots \ldots \ldots \ldots \ldots \ldots \ldots \ldots$

Appendix D - Bechtel Nevada, Remote Sensing Laboratory Report on the Second and Third Characterization Events $\ldots \ldots \ldots \ldots \ldots \ldots \ldots$ D-1

Appendix E - Vertical Profile Plots for Americium and Plutonium in Soil . ........... E-1

Appendix F - Soil Particle-Size and Volume Reduction Data . . . . . . . . . . . . F-1

Appendix G - Passive Alpha Detector Data Summaries and Result Discussions ........ G-1 


\section{List of Figures}

Number

Page

1-1 Location of Double Tracks Test Site

1-2 Nevada Applied Ecology Group Soil Sampling Locations and Results . . . . . 1-6

1-3 EG\&G 1977 Aerial Radiological Survey of the Double Tracks Test Site . . . . . . 1-8

1-4 EG\&G 1993 Aerial Radiological Survey of the Double Tracks Test Site ..... . 1-10

3-1 Location of Soil Samples Collected During the First Characterization Event . . . . 3-2

3-2 Location of Hot Spot Soil Profile Samples Collected During the Second

Characterization Event ............................. 3-5

3-3 Uranium Isotope Versus Plutonium-239/240 Activity in Double Tracks

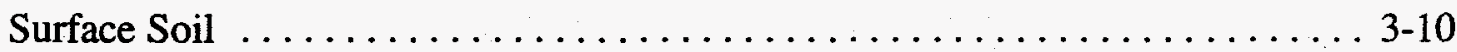

3-4 Activity Ratio of Plutonium-239/240 to Americium-241 in Double Tracks

Surface Soil (Assuming Negligible Initial Americium-241 Ingrowth) . . . . . . 3-12

3-5 Americium-241 Versus Plutonium-239/240 Activity in Double Tracks

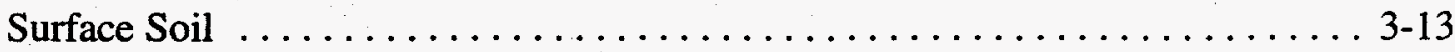

3-6 Total Transuranic Isotope Activity of Double Tracks Soil, Based on the 1995

EG\&G Ground Survey ......................... 3-22

3-7 Location of Soil Borings in Ground Zero Area of the Double Tracks Test Site . 3-25

3-8 Location of Soil Samples Collected During the Fourth Characterization

Event 


\section{List of Tables}

Number

1-1 Isotopic Composition of Plutonium and Uranium Used in the Double Tracks Test Device

1-2 Estimated Size of Areas Exceeding Specified Concentrations of Plutonium at the Double Tracks Test Site

3-1 Radionuclide Activity in Surface Soil at the Double Tracks Test Site

3-2 Radionuclide Activities in Surface Soil Samples Collected from Hot Spot Locations

3-3 Background Radioactivity in Surface Soil 3-8

3-4 Source of Radionuclides in Double Tracks Surface Soil

3-5 Field Collimated HPGe Detector Measurements of Metal Fragments and Hot Spot Soil

3-6 Metal Concentrations in Surface Soil at the Double Tracks Test Site

3-7 Toxicity Characteristic Leaching Procedure Results for Surface Soil Samples from the Double Tracks Test Site

3-8 In Situ Radiological Measurements of Depth Profiles at the Double Tracks Test Site 3-24

3-9 In Situ Radiological Measurements in Ground Zero Soil Borings $3-27$

3-10 Grain-Size Analysis of Treatability Study Samples 3-29 


\section{List of Tables (Continued)}

3-11 Summary of Gamma Spectroscopy and Isotopic Analysis of Treatability Study

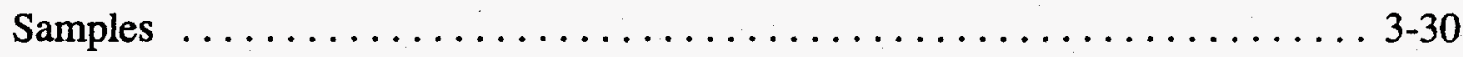

3-12 Estimates of Area and Volume of Soil Exceeding 200 Picocuries per Gram of Total Transuranic Isotope Activity at the Double Tracks Test Site . . . . . 3-32 


\section{List of Acronyms and Abbreviations}

ATD

ATV

ASTM

CFR

cm

cpm

DOE

DRI

EIC

EPA

FIDLER

$\mathrm{ft}$

GPS

HPGe

in.

IT

ITPDL

$\mathrm{kg}$

$\mathrm{km}$

lb

$\mathrm{m}$

$\mathrm{m}^{3}$

MAL

$\mathrm{mg} / \mathrm{kg}$

$\mathrm{mg} / \mathrm{L}$

mi

NAEG

NAFR

$\mathrm{NaI}$

NAS

NTS

$\mathrm{pCi} / \mathrm{g}$

ppm
Alpha Track Detector(s)

All-terrain vehicle

American Society for Testing and Materials

Code of Federal Regulations

Centimeter(s)

Count(s) per minute

U.S. Department of Energy

Desert Research Institute

Electrode Ionization Chamber(s)

U.S. Environmental Protection Agency

Field Instrument for the Detection of Low-Energy Radiation

Foot (feet)

Global positioning system

High-purity germanium

Inch(es)

IT Corporation

IT Process Development Laboratory

Kilogram(s)

Kilometer(s)

Pound(s)

Meter(s)

Cubic meter(s)

Minimum activity level

Milligram(s) per kilogram

Milligram(s) per liter

Mile(s)

Nevada Applied Ecology Group

Nellis Air Force Range

Sodium iodide

National Academy of Sciences

Nevada Test Site

Picocurie(s) per gram

Part(s) per million 
RCRA Resource Conservation and Recovery Act

SAFER Streamlined Approach for Environmental Restoration

TAL Target analyte list

TCLP Toxicity characteristic leaching procedure

TNT Trinitrotoluene

TTR Tonopah Test Range

TRU Transuranic

$\mathrm{yd}^{3} \quad$ Cubic yard(s)

$\mu \mathrm{Ci} \quad$ Microcurie(s)

$\mu \mathrm{Ci} / \mathrm{g} \quad$ Microcurie(s) per gram

$\mu \mathrm{g} / \mathrm{g} \quad$ Microgram(s) per gram 



\subsection{Introduction}

This report presents the results of site characterization activities performed at the Double Tracks Test Site, located on Range 71 North, of the Nellis Air Force Range (NAFR) in southern Nevada. Site characterization activities included reviewing historical data from the Double Tracks experiment, previous site investigation efforts, and recent site characterization data. The most recent site characterization activities were conducted in support of an interim corrective action to remediate the Double Tracks Test Site to an acceptable risk to human health and the environment. Site characterization was performed using a phased approach. First, previously collected data and historical records were compiled and reviewed. Generalized scopes of work were then prepared to fill known data gaps. Field activities were conducted and the collected data were then reviewed to determine whether data gaps were filled and whether other areas needed to be investigated. Additional field efforts were then conducted, as required, to adequately characterize the site. Characterization of the Double Tracks Test Site was conducted in accordance with the U.S. Department of Energy's (DOE) Streamlined Approach for Environmental Restoration (SAFER).

\subsection{Purpose}

This report presents the data and conclusions derived from the characterization activities that were conducted at the Double Tracks Test Site. Because characterization was conducted in support of an interim corrective action, field activities focused on adequately characterizing the site to a level so that interim corrective action could be determined. The characterization included determining the nature and extent of contamination, estimating the volume of contaminated soil and debris, and adequately characterizing the soil to meet disposal criteria.

\subsection{Site Description and History}

The Double Tracks test site is located in Stonewall Flat on Range 71 North, of the NAFR, northwest of the Nevada Test Site (NTS) (Figure 1-1). The nearest town is Goldfield, Nevada, located approximately 22 kilometers $(\mathrm{km})$ (14 miles [mi]) west of the site. By existing road (through the Tonopah Test Range [TTR] and U.S. Highways 6 and 95), Goldfield is approximately $132 \mathrm{~km}$ (82 mi), and Mercury, Nevada, is approximately $362 \mathrm{~km}$ (224 mi) from the Double Tracks Test Site.

Double Tracks was the first of four experiments that constituted Operation Roller Coaster. On May 15, 1963, plutonium, depleted uranium, and trace amounts of other isotopes were placed on 


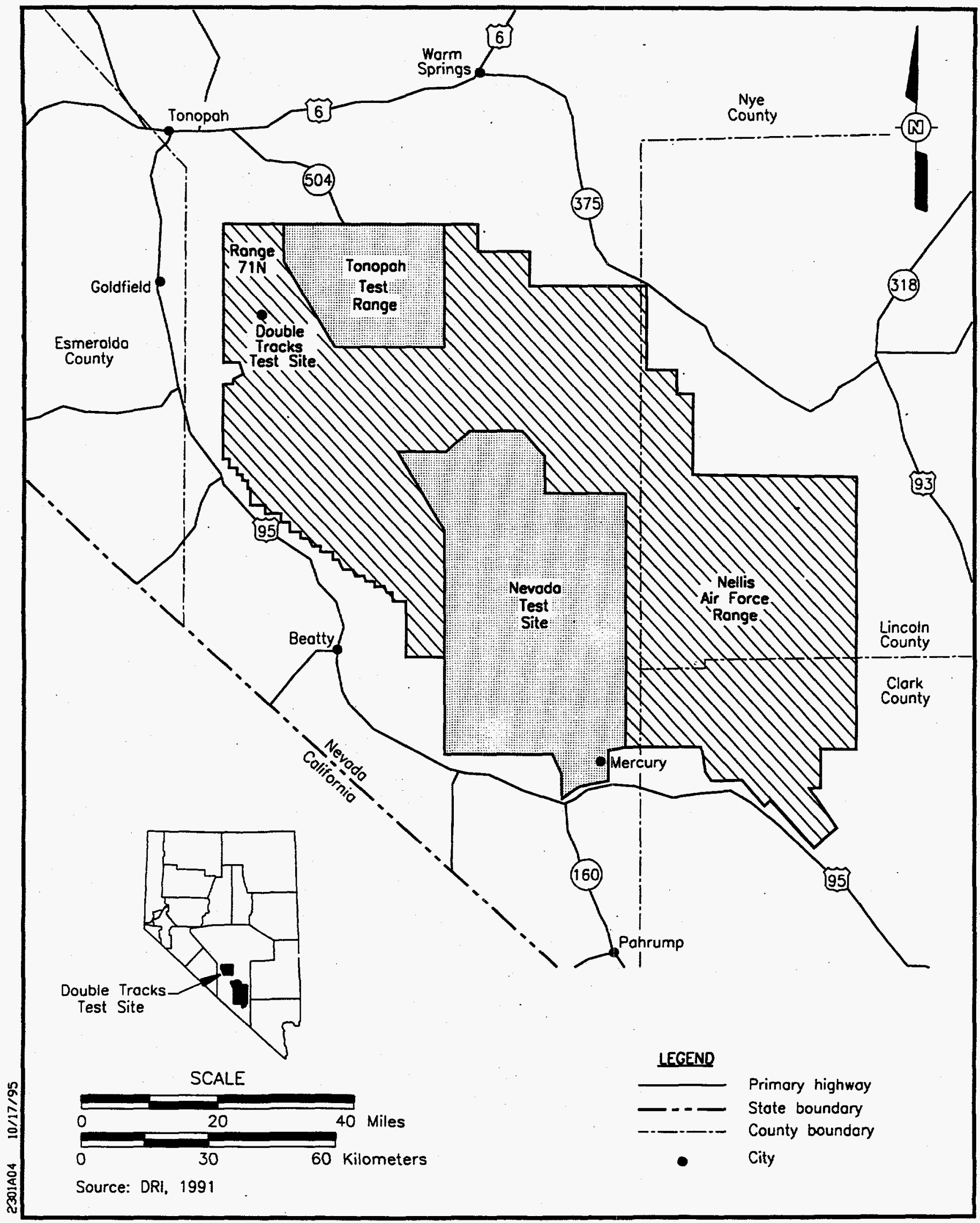

Figure 1-1

Location of Double Tracks Test Site 
a 2.4- by 2.4-meter (m) (8- by 8-foot [ft]) steel plate that was supported by a 6.1- by 6.1-m (20- by $20-\mathrm{ft}$ ), $0.3-\mathrm{m}$ ( $1-\mathrm{ft}$ )-thick reinforced concrete pad. The radioactive material was dispersed using 54 kilograms $(\mathrm{kg})$ (118 pounds [lbs]) of trinitrotoluene (TNT) explosive (Church, 1969; Shreve, 1965). The explosion occurred in the open, $0.3 \mathrm{~m}(1 \mathrm{ft})$ above the steel plate (Menker et al., 1966). No fission yield was detected from the test, and the total amount of plutonium deposited on the steel plate, concrete slab, and ground surface was estimated to be between 980 and 1,600 grams (Shreve, 1965). Table 1-1 lists the isotopic composition of plutonium and uranium used in the device (Menker et al., 1966). The test device was composed primarily of uranium-238 (U-238) and plutonium-239 (Pu-239). Menker et al. (1966) reported that the weight ratio of uranium to plutonium in the device was 4.35 .

Table 1-1

\section{Isotopic Composition of Plutonium and Uranium Used in the Double Tracks Test Device ${ }^{a}$}

\begin{tabular}{||c|c|c|}
\hline Isotope & Weight Percent & Activity Percent $^{\mathrm{b}}$ \\
\hline Plutonium-238 & 0.00387 & 0.30 \\
\hline Plutonium-239 & 97.314 & 27.53 \\
\hline Plutonium-240 & 2.530 & 2.62 \\
\hline Plutonium-241 & 0.1487 & 69.55 \\
\hline Plutonium-242 & 0.00310 & 0.0000554 \\
\hline Total Plutonium & 100 & 100 \\
\hline Uranium-234 & 0.00074 & 12.00 \\
\hline Uranium-235 & 0.165 & 0.93 \\
\hline Uranium-238 & 99.834 & 87.08 \\
\hline Total Uranium & 100 & 100 \\
\hline
\end{tabular}

${ }^{a}$ Menker et al. (1966)

${ }^{b}$ Converted from weight percent, using specific activity

The objectives of the Double Tracks experiment were to evaluate the dispersal of radionuclides in the environment and the uptake and fate of plutonium in several animal species. The experiment scattered radioactive material, earth, and other material (concrete and metal) into the air. The debris and most of the dirt fell to earth at relatively short distances from the GZ area. 
However, some of the finer grained material was spread over a larger area downwind, to the south of ground zero. The debris in the vicinity of ground zero and identified fragments to distances of 90 to $120 \mathrm{~m} \mathrm{(300} \mathrm{to} 800 \mathrm{ft}$ ) were collected and buried near ground zero.

Contaminated surface soil in the vicinity of ground zero reportedly was scraped to a depth of several inches and mounded, covered with clean dirt, and compacted. The steel plate was buried in the clean slates radiation disposal pit, but was later exhumed and transported to the NTS for analysis and disposal. Except for these postevent activities, no decontamination of the site was reported. Postevent sampling and surveying were conducted to determine contamination levels and distribution and are summarized in Section 1.4.

\subsection{Physical Characteristics of the Site}

The Double Tracks Test Site is located on Stonewall Flat, an alluvial basin that is bordered by the Cactus Range to the east, the Goldfield Hills to the north, and Stonewall Mountain to the south (Ekren et al., 1972). The depth of the alluvial material beneath the site is not accurately known but is suspected to be deeper than $250 \mathrm{~m}$ ( $800 \mathrm{ft}$ ). Groundwater in the vicinity of the Double Tracks Test Site is at an elevation of approximately $1,400 \mathrm{~m}(4,500 \mathrm{ft})$, or approximately $150 \mathrm{~m}(500 \mathrm{ft})$ below ground surface (Thomas et al., 1986). This first occurrence of groundwater is in the alluvial material.

The Double Tracks Test Site is relatively flat, with surface runoff toward the southwest. The elevation of the site is approximately $1,524 \mathrm{~m}(5,000 \mathrm{ft})$ above mean sea level. Average annual precipitation at Goldfield for the years 1948 to 1989 was 11.8 centimeters (cm) (4.6 inches [in.]) (unpublished, Office of the Nevada State Climatologist). Major plant species found on the site are shadscale (Atriplex confertifolia), budsage (Artemisia spinescens), winterfat (Ceratoides lanata), greasewood (Sarcobatus vermiculatus), burrobush (Hymenoclea salsola), and Indian ricegrass (Oryzopsis hymenoides). Soils are predominantly gravelly, sandy loams and gravelly loams (Leavitt, 1974), and blow-sand mounds are common beneath shrubbery.

\subsection{Previous Investigations}

Periodic alpha radiation surveys of the Double Tracks test site were conducted for several years following the event (Glora and Brown, 1964; Glora and Aoki, 1966). Leavitt (1974) conducted a soil classification survey of the Double Tracks Test Site and characterized the soil as gravelly, sandy loam and gravelly loam. Leavitt also reported that plant density is 5 to 15 percent.

In the 1970s, the Nevada Applied Ecology Group (NAEG) performed a systematic survey of suspected surface-contaminated sites on the NTS, TTR, and NAFR. The following activities 
were conducted at the Double Tracks Test Site as part of the NAEG investigation (Gilbert et al., 1975):

- An in situ radiological survey using a Field Instrument for the Detection of Low-Energy Radiation (FIDLER)

- Collection of surface soil samples (0- to 5-cm [0- to 2-in.] depth) using a stratified random sampling scheme based on FIDLER survey results. Laboratory analyses were performed on 53 samples for Pu-239/240 and 33 samples for americium-241 (Am-241)

- Collection of vegetation samples and laboratory analysis of 48 samples for Pu-239/240 and 40 samples for Am-241

- Collection of five vertical soil profile samples consisting of ten 2.5-cm (1.0-in.) incremental samples collected to a depth of $25 \mathrm{~cm}$ (10 in.) and analysis of samples for Pu-239/240 and Am-241.

Figure 1-2 shows the locations and $\mathrm{Pu}-239 / 240$ concentrations of the surface soil samples collected by the NAEG. Most of the samples were collected near ground zero and may not represent undisturbed fallout from the experiment because much of the soil was reworked during postevent activities. The soil data indicate that the concentration of plutonium in surface soil is highly variable over relatively small distances. From the NAEG surface soil data, Gilbert (1977) estimated the inventory of $\mathrm{Pu}-239 / 240$ in the upper $5 \mathrm{~cm}$ ( 2 in.) of Double Tracks soil to be 3.6 curies, with a 95 percent confidence interval of 1.7 to 5.5 curies. Kinnison and Gilbert (1982) calculated that using a 160-picocurie per gram (pCi/g) cleanup level and removing the top $15 \mathrm{~cm}$ ( 6 in.) of soil at Double Tracks would yield a soil volume of 9,200 cubic meters $\left(\mathrm{m}^{3}\right)\left(12,030\right.$ cubic yards $\left.\left[\mathrm{yd}^{3}\right]\right)$. With an average density of 1,100 kilograms per cubic meter for Double Tracks soil (Martin and Bloom, 1977), the mass of soil removed would be $1.0 \times 10^{7} \mathrm{~kg}$ $\left(2.2 \times 10^{7} \mathrm{lbs}\right)$.

Using the 1974 NAEG surface soil data, the average $\mathrm{Pu}-239 / 240$ to Am-241 activity ratio was estimated to be 24, with a standard error of 0.64 (Gilbert et al., 1975). Kinnison and Gilbert (1982) reported that the average ratio for Double Tracks soil is 20, with a standard deviation of 4, based on more recent (1977) data from the NAEG. Kinnison and Gilbert also reported an average $\mathrm{Pu}-239 / 240$ to $\mathrm{Pu}-238$ activity ratio of 100 , with a standard deviation of 26 . This ratio is consistent with the ratio of these isotopes reported for the Double Tracks device (Table 1-1). 


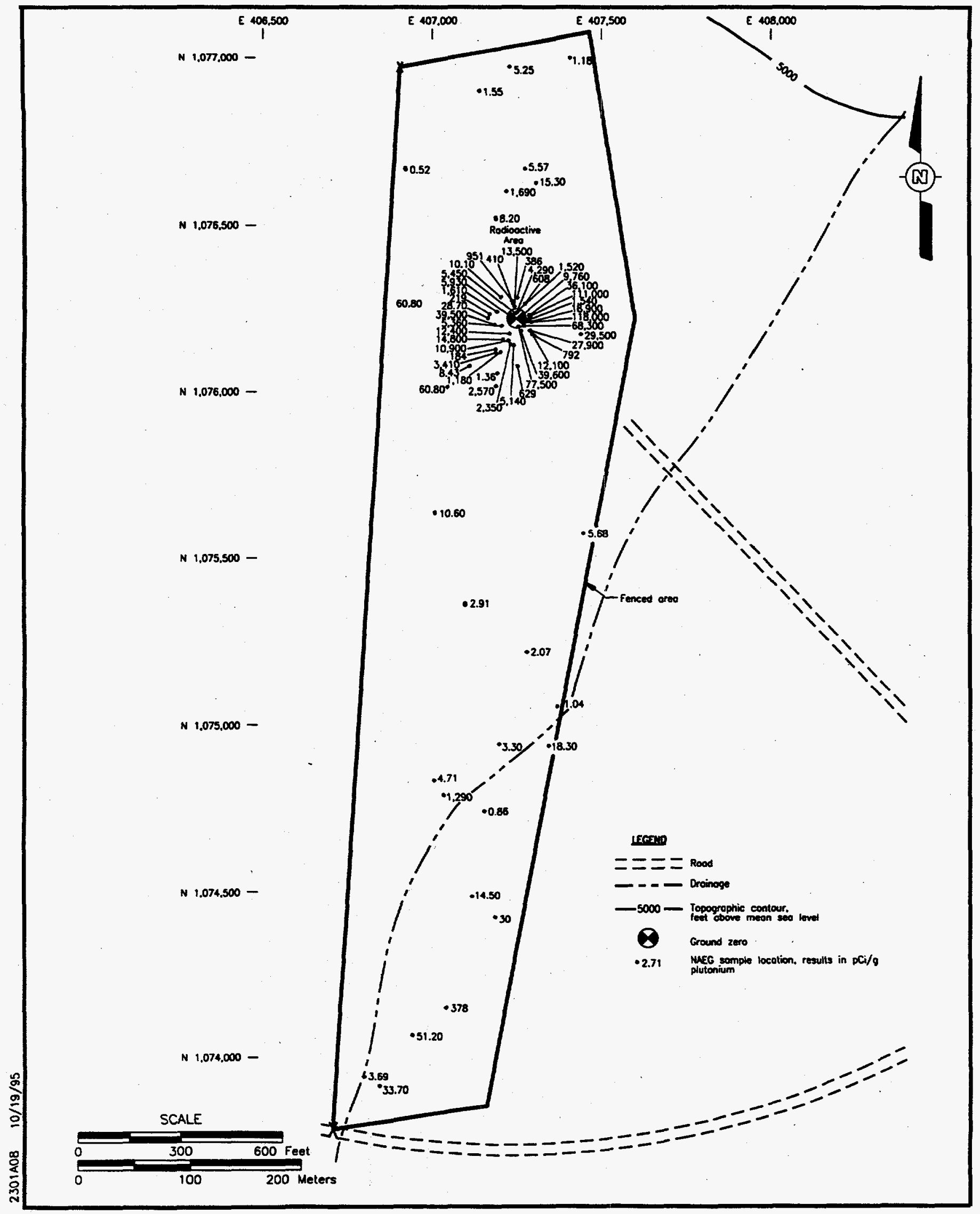

Figure 1-2

Nevada Applied Ecology Group Soil Sampling Locations and Results 
Essington et al. (1975) presented the results of NAEG vertical soil profile sampling at Double Tracks. When the Pu-239/240 activity of the top 5-cm (2-in.) soil sample was compared with the activity of the 5 - to $25-\mathrm{cm}$ (2- to 10 -in.) interval, they found that the proportion ranged from 48 to 99 percent. These results may indicate that the soil has either been disturbed by site activities or the plutonium has moved downward at some locations. Essington et al., suggested that plutonium may move down the soil profile to caliche layers or layers where lime lenses are in the process of forming. The plutonium may be accumulating in these layers by cation exchange. Essington et al. (1975) also indicated that Am-241 moved more readily into the soil profile, based on changes in the Pu-239/240 to Am-241 ratio with depth. NAEG studies also have shown that plant uptake of americium is greater than that of plutonium (Friesen, 1992).

A study by the DOE (1995a) used the 1974 NAEG surface soil data to estimate the Double Tracks Test Site surface areas that exceed specified plutonium concentrations. These estimates are shown in Table 1-2.

Table 1-2

Estimated Size of Areas Exceeding Specified Concentrations of Plutonium at the Double Tracks Test Site ${ }^{a}$

\begin{tabular}{|c|c|c|c|c|c|c|c|}
\hline & \multicolumn{6}{|c|}{ Area, A (hectares) exceeding X picocuries per gram of plutonium } \\
\hline $\mathrm{X}=$ & 1,000 & 400 & 200 & 150 & 100 & 40 & 10 \\
\hline $\mathrm{A}=$ & 1 & 1 & 3 & 4 & 7 & 8 & 11 \\
\hline
\end{tabular}

${ }^{a}$ DOE, 1995a

These volume estimates have been revised using site characterization data collected in preparation of the interim corrective action. The new volume estimates are presented in Section 3.7 .

An aerial radiological survey of the Double Tracks Test Site was conducted in 1977 by EG\&G for the NAEG (Jobst, 1979). The survey was conducted from a helicopter at an altitude of $30 \mathrm{~m}$ $(100 \mathrm{ft}$ ). A gamma ray from Am-241 was measured with sodium iodide ( $\mathrm{NaI}$ ) detectors, and the $\mathrm{Pu}-239 / 240$ to Am-241 ratio determined by Gilbert et al. (1975) was used to estimate the $\mathrm{Pu}-239 / 240$ activity of the surface soil. Figure 1-3 shows the isopleth map of americium and plutonium activity determined by the EG\&G aerial survey. There appears to be an error on the conversion of count rates to activity for this survey. The activity should be about a factor of 



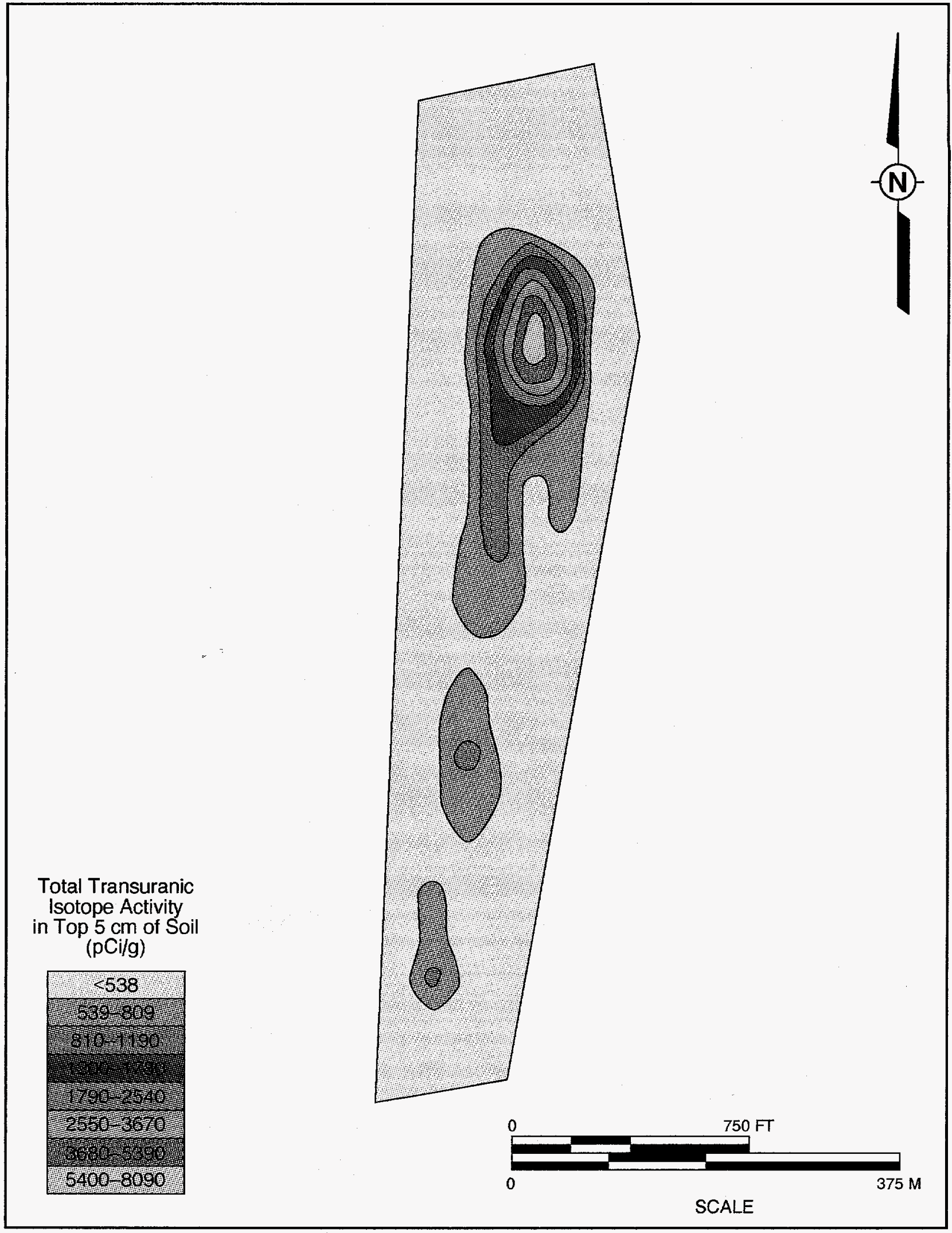

Figure 1-3

EG\&G 1977 Aerial Radiological Survey of the Double Tracks Site 

10 less than reported. The Double Tracks Test Site was resurveyed in 1993 by EG\&G, again from an altitude of $30 \mathrm{~m}$ (100 ft), with NaI detectors mounted on a helicopter (Hendricks, 1995). The results of this survey are shown in Figure 1-4. Please note that the results presented in Figure 1-4 are large-area averaged, which at the time this investigation was conducted appeared to best represent the extent of contamination. 


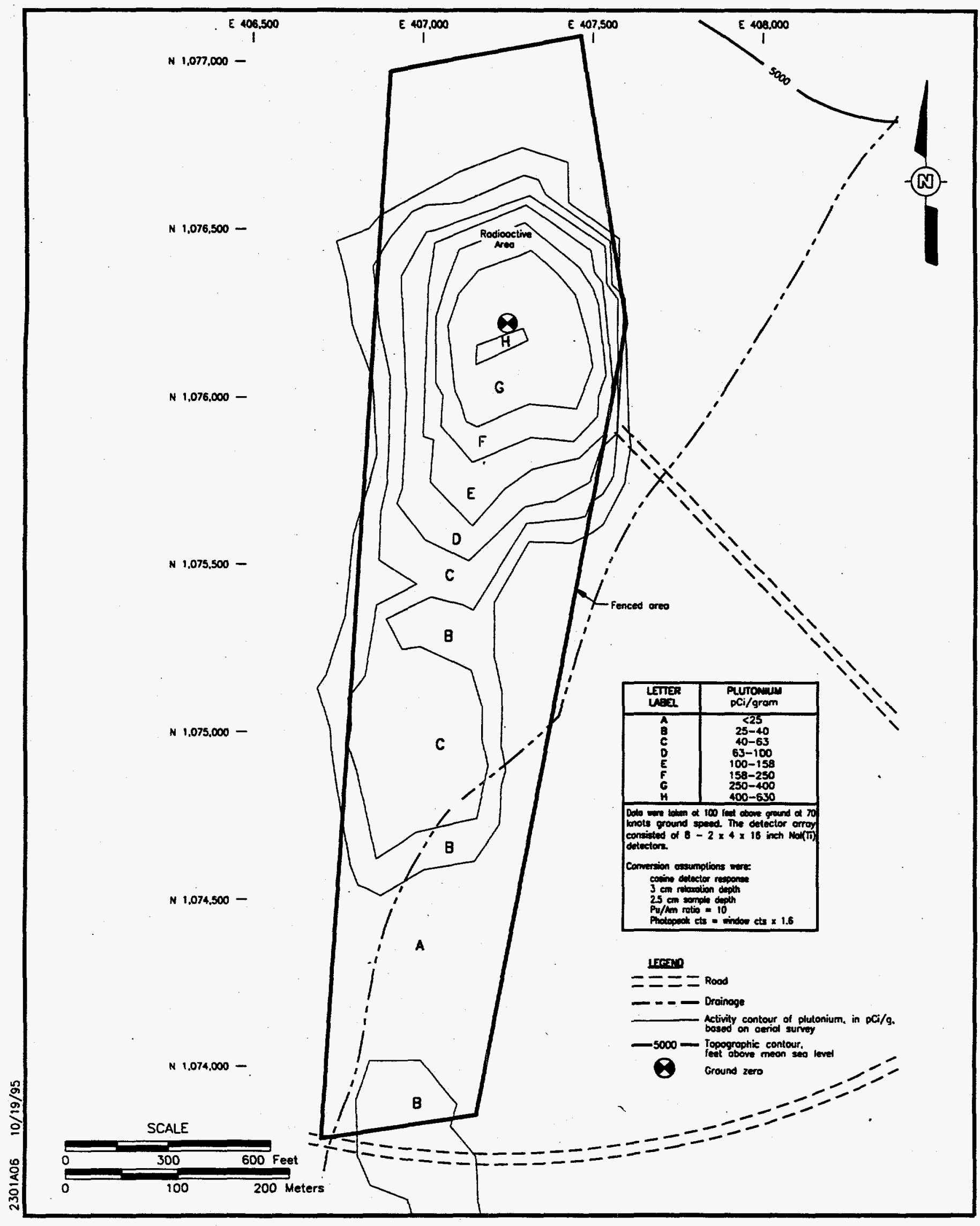

Figure 1-4

EG\&G 1993 Aerial Radiological Survey of the Double Tracks Test Site 


\subsection{Site Characterization Activities}

To fill identified data gaps, additional site characterization activities were conducted at Double Tracks Test Site on four separate occasions from October 1994 to August 1995. The characterization phases are referred to as events in this report because the term "phase" has regulatory connotations that do not apply.

The four characterization events consisted of the following:

- During the first characterization event, discrete vertical soil profile samples were collected for analysis of radionuclides and metals.

- During the second characterization event, various radiological surveying systems and techniques were evaluated, hot spots (areas of anomalously elevated radioactivity) were identified and sampled, and additional depth profiles were sampled.

- During the third characterization event, systematic radiological surveys of the Double Tracks Test Site were performed, along with some additional characterization of the ground zero area.

- During the fourth characterization event, soil samples were collected from previously identified contaminated areas for treatability testing.

These characterization events were conducted in accordance with the Soils Media Operable Unit Quality Assurance Project Plan (DOE, 1995b). The characterization activities for each event are discussed in more detail in the following sections.

\subsection{Characterization Event 1}

The first characterization event at the Double Tracks Test Site was conducted in October 1994. The goal of this characterization field effort was to collect discrete soil samples to confirm the NAEG sample and EG\&G aerial survey results. In addition, samples were collected for toxicity characteristic leaching procedure (TCLP) testing to evaluate disposal requirements and determine whether mixed waste was present. The laboratory analytical results were expected to be used in the accurate determination the $\mathrm{Pu}-239 / 240$ to $\mathrm{Am}-241$ ratio.

Discrete soil samples were collected from 12 locations within the exclusion zone. The sampling locations were selected based on the 1977 and 1993 aerial surveys and NAEG sample results. At 
each sample location, vertical profile soil samples were collected from the following depth intervals:

- 0 to $5 \mathrm{~cm}(0$ to 2 in.)

- 5 to $10 \mathrm{~cm}(2$ to $4 \mathrm{in}$.)

- 10 to $15 \mathrm{~cm}(4$ to $6 \mathrm{in}$.)

- 22.5 to $30 \mathrm{~cm}(9$ to $12 \mathrm{in}$.)

Samples from the three upper intervals were submitted to a laboratory for analysis of isotopic americium, plutonium, and uranium. The uppermost sample intervals were also analyzed for gamma-emitting radionuclides and total target analyte list (TAL) metals. The TAL is a list of analytes specified in Resource Conservation and Recovery Act (RCRA) to characterize waste and waste streams. Because previous investigations indicated that most of the contaminants were in the top several centimeters, the lowest interval sample from each location was archived and not analyzed. If contaminants were detected in the sample immediately above the archived sample, then the archived sample was to be analyzed. This sample analysis strategy follows the SAFER approach of collecting and analyzing the minimum number of samples required for the adequate characterization of a site.

In addition to the analyses described, soil from the uppermost interval ( 0 to $5 \mathrm{~cm}$ [0 to 2 in.]) at three sample locations was submitted for TCLP testing and the extract was analyzed for RCRA metals to provide information on soil waste disposal requirements. Appendix A presents additional details on the sampling and analysis performed during the first site characterization event.

\subsection{Characterization Event 2}

Results of the first characterization event indicated that the spatial distribution of radiological contamination in surface soil was highly variable and that the extent of soil contamination at the Double Tracks Test Site was not as uniform as previously assumed. As a result, it is difficult to accurately delineate the extent of soil contamination based only on soil sample results. Because of this, the second characterization event focused on evaluating the use of in situ radiological survey equipment and methods to delineate the extent of contamination and characterize the Double Tracks Test Site. In addition, because hot spots were thought to be biasing the aerial survey measurements, experiments were conducted to determine the size and depth of the hot spots and whether they could be removed. Several hot spot removal methods were tried to determine the most cost- effective approach. Finally, additional soil samples were collected from areas with elevated activities to determine the $\mathrm{Pu}-239 / 240$ to Am-241 ratio more accurately. 
The second characterization event was conducted in April 1995. Additional details on the field activities performed are presented in Appendices A, B, and D. Specific activities conducted during the second characterization event are discussed in the following sections.

\subsubsection{Surface Radiation Measurements}

A small-scale radiation survey was conducted over a limited area at the Double Tracks Test Site. The area selected for this survey was known to have elevated radioactivity, as determined from aerial radiological surveys conducted by EG\&G (Section 1.4). The objective of the survey was to obtain data from several surface in situ detector systems and compare them with laboratory results. The following detector systems were used:

- A Suburban-mounted collimated high-purity germanium (HPGe) detector

- A tripod-mounted collimated HPGe detector

- A hand-held FIDLER

A tripod-mounted collimated system was placed near ground zero for approximately 1 to 2 hours to measure radioactivity with suitable accuracy to determine the Pu-238/239 to Am-241 ratio. In addition, the Suburban-mounted HPGe system was used outside the immediate ground zero area to evaluate the uniformity of the radiation field by taking measurements from different heights at the same location.

\subsubsection{Hot Spot Investigations}

Hot spots identified during the small-scale radiological survey (Section 2.2.1) were investigated further to determine the nature of the elevated radioactivity and to evaluate the feasibility of removing the hot spots. Once located by in situ surveying, hot spots were physically removed using a combination of methods, and the area was resurveyed. This process was continued until approximately 80 to 90 percent of the radioactivity, determined by field instrument count rates, had been removed.

To assist in determining the nature and size of the hot spot material, several hot spot soil samples were split in the field by passing the soil through a Jones splitter device. After a single sample was split into two equal-sized subsamples, the FIDLER instrument was used to survey the subsamples. This activity was designed to provide information on the distribution of radioactive particles in the hot spot soil. For each split sample, the subsample with the highest measured radioactivity was retained for laboratory analysis. If relatively large metallic fragments were found in a hot spot soil sample, the fragments were removed from the sample and stored at the 
Double Tracks Test Site within the exclusion zone. Six hot spot soil samples (some of which were also depth profile samples; Section 2.2.3) were submitted to a laboratory for analysis of americium, isotopic plutonium and total uranium. Four hot spot samples were submitted for TCLP testing of RCRA metals to provide information on soil waste disposal requirements. In addition, a particle-size analysis/separation was performed on one hot spot soil sample, and the separated fractions were analyzed for gross alpha and beta activity, to support the evaluation of a volume reduction alternative.

\subsubsection{Depth Profile Samples}

To assess the vertical distribution of contamination, depth profile sampling experiments were performed at four locations of elevated radioactivity. A tripod-mounted collimated HPGe detector or hand-held FIDLER detector was used to measure the radioactivity of the undisturbed sample location. After this measurement, a layer of soil (approximately 1 to $2 \mathrm{~cm}$ ) was physically removed from the location starting at ground surface, and the radioactivity was remeasured. This process was continued until approximately 80 to 90 percent of the radioactivity had been removed. The first (uppermost) layer of soil from three of the four hot spot locations was submitted to a laboratory for analysis of americium, isotopic plutonium, and total uranium.

\subsubsection{Passive Alpha Detector Measurements}

Two types of passive alpha detectors were field tested to evaluate their effectiveness for screening alpha-emitting contaminated soil at the Double Tracks Test Site. Electrete Ionization Chambers (EICs) measure air ionization due to alpha emission from the soil surface. Alpha Track Detectors (ATDs) measure alpha particles as microscopic emission from the soil surface. Each of the detectors tested was deployed in several types of arrays in areas of known contamination. The deployment times ranged from 5 minutes to 5 days. Surface deployment consisted of laying the detectors directly on the contaminated soil and covering them to protect the detectors from airborne (dust) contamination and adverse weather. Depth profiles were also conducted by driving a small diameter stake $20 \mathrm{~cm}$ into the ground, removing the stake, and then inserting the detectors into the open hole. To correlate these detectors with other in situ measurements, several experiment locations were also surveyed with the tripod- and boom-mounted HPGe detector.

Results from the EIC and ATD detector experiments indicated that these types of detectors cannot cost effectively be used to characterize the Double Tracks Test Site. The disadvantage of these detectors is that they were very susceptible to airborne (dust) contamination and they could not systematically identify hot spots over a relatively large area. The advantages of these detectors is that they were relatively inexpensive, responded well to contamination levels 
encountered at the Double Tracks Test Site, and can provide immediate on-site readout. During this experiment the detection limits ranged from $100 \mathrm{nCi} / \mathrm{g}(\mathrm{Pu}+\mathrm{Am})$ to $22 \mathrm{pCi} / \mathrm{g}$ (total alpha).

The depth profile experiment did not yield usable results and therefore will not be discussed any further in this document. A more in-depth discussion of results from these detector experiments is presented in Appendix $\mathrm{G}$.

\subsection{Characterization Event 3}

The third characterization event at the Double Tracks Test Site was conducted in June 1995. The goal of this field effort was to remove all hot spots from the areas to be surveyed and then survey the site to determine the extent of radiological contamination with accuracy. In addition, several pieces of metal from the hot spots were weighed and counted using a sensitive collimated detector to determine whether transuranic (TRU) material was present. Several in situ radiation field instruments were used to cross-correlate the results in the field to determine whether the site was being accurately characterized. Appendices A and B present additional details on the field activities performed during this stage of characterization.

\subsubsection{Radiological Surveys}

Several radiological surveys were conducted concurrently to cross-correlate results. These surveys are discussed individually in the sections that follow.

\subsubsection{All-Terrain Vehicle-Mounted FIDLER Survey}

This measurement system consisted of three FIDLERs mounted on the front of an all-terrain vehicle (ATV). The FIDLERS were mounted approximately $1 \mathrm{~m}(3 \mathrm{ft})$ above ground surface. The combined field of view of the three detectors was approximately $1.5 \mathrm{~m}(5 \mathrm{ft})$. The ATV was used to conduct a systematic survey of the contaminated area for hot spots. Traverses were made on approximately $1.5-\mathrm{m}(5-\mathrm{ft})$ centers. The ATV operator dropped a flag at locations where hot spots were detected. The intent of this survey was to remove fragments and hot spots prior to conducting additional instrument surveys.

\subsubsection{Suburban-Mounted Sodium-lodide Detector Survey}

This measurement system consisted of three pods of NaI detectors mounted on the rear bumper of a specially designed Suburban vehicle (named the Kiwi). The system was combined with a differential global positioning system (GPS) to provide both an in situ radioactivity measurement and an accurate location. Sets of $\mathrm{NaI}$ detectors were previously used in the aerial (helicopter) system. Because the detectors are closer to the ground, spatial resolution and sensitivity were 
increased relative to the previous aerial surveys. At an aboveground distance of $0.8 \mathrm{~m}(2.5 \mathrm{ft})$, the array of $\mathrm{NaI}$ detectors produced a field of view of approximately $3 \mathrm{~m}(10 \mathrm{ft})$. The positional

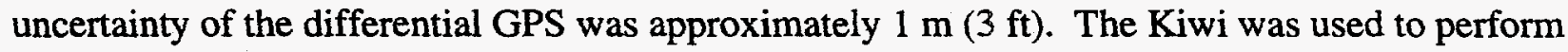
a systematic survey of the Double Tracks Test Site to establish with accuracy the extent of contamination. This survey was performed after most known hot spots had been removed, but the Kiwi surveyed part of the area before the ATV could locate and remove all of the metallic material or hot spots.

\subsubsection{Suburban Mast-Mounted HPGe Detector Survey}

This measurement system consisted of a collimated HPGe detector mounted on an extendable mast attached to a Suburban vehicle. When the mast was fully extended, the field of view covered an approximately $13-\mathrm{m}$ (43-ft)-diameter area. The system was used to make in situ radioactivity measurements in and around Double Tracks contaminated areas. Outside these areas, measurements were made to determine background. Inside the exclusion zone, the HPGe detector system was used to confirm the measurements made by the Kiwi system. Although the boom mounted collimated HPGe detector was shown to provide the most reliable in situ measurements, the measurements require relatively long count times ( 5 to 10 minutes).

\subsubsection{Jeep-Mounted Scintillation Detector Survey}

To cross-check the other in situ radiological survey results, a scintillation detector system mounted on the bumper of a Jeep Cherokee was used to survey the contaminated areas at the Double Tracks Test Site. This survey was also used to assist in the location of hot spots. Results indicated that this system was not as sensitive as the other instrument systems used. The scintillation detector system will not be discussed again in this document.

\subsubsection{Hot Spot Mining}

As previously stated, relatively large, highly radioactive metallic fragments were discovered at hot spot locations during the second characterization event. During the third characterization event, hot spot materials were identified and the fragments were removed and taken to a central location. Several of the fragments were then characterized by measuring radioactivity using a collimated HPGe detector, weighing the samples, and photographing them.

\subsubsection{Ground Zero Characterization}

Historical records indicate that debris and contaminated soil in the immediate vicinity of ground zero were removed, scraped, and mounded up at ground zero (Section 1.2). In situ radiological surveys could not be performed at ground zero because of elevated activities, at times exceeding 
$5,000 \mathrm{pCi} / \mathrm{g}$. Therefore, all of the ground zero mound was assumed to be contaminated even though clean fill was documented as having been placed on top of the mound.

To provide for a better understanding of the nature and extent of contamination in the ground zero area, several field activities were conducted to measure the volume of the mound and characterize its contents. To determine the vertical extent of contamination, 17 shallow boreholes were advanced in the ground zero area using manual and power augers. The depths of

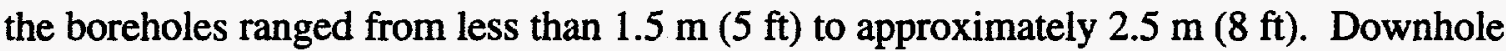
radiation measurements were recorded using a $\mathrm{NaI}$ detector to determine the bottom of the mound. Several of the boreholes intercepted a hard layer that was assumed to be the concrete pad used in the Double Tracks test.

\subsection{Characterization Event 4}

The fourth characterization event was conducted on July 25,1995 . The objective of this field effort was to collect contaminated soil samples for treatability testing. The goal of the treatability analysis was to determine if a physical separation process (grain-size separation) is a costeffective option to reduce the volume of soil requiring disposal during site remediation.

Soil sample locations were chosen so that a representative suite of samples could be collected from contaminated areas at the Double Tracks Test Site, excluding ground zero, that adequately represent soil that will require remediation. The sampling locations were selected based on previous ground survey results. The first sample location was approximately $61 \mathrm{~m}(200 \mathrm{ft})$ south of ground zero, in the approximate center of the contaminant plume. Samples were then collected every $30 \mathrm{~m}$ ( $100 \mathrm{ft}$ ) south along the axis of the contaminant plume. To reduce the potential of cross contamination, samples were collected from least to most contaminated locations (south to north).

Based on previous soil sampling experience, as well as previous analytical results, it was known that the contaminants at the Double Tracks Test Site are not homogeneous. Therefore, the sampling procedures included mechanically splitting the soil sample several times with a Jones splitter to achieve a more representative sample at each location. The soil splitting consisted of the following:

- Two soil samples were collected from the upper 2 to $4 \mathrm{~cm}$ at each sample location. Each soil sample was approximately 2 liters. 
- Each of these samples was mechanically split with half of each sample discarded and the second half from each sample combined. The combined sample was then mechanically split a second time.

- Each of the second sample splits was retained. One split sample was sent to Desert Research Institute (DRI) for analysis at the NTS and the other was sent to the IT Corporation (IT) Process Development Laboratory (ITPDL) in Knoxville, Tennessee.

The IT laboratory analysis consisted of wet screening approximately 1,000 to 1,500 grams of soil from each sample to develop a bulk soil characterization profile. The course fraction, i.e., soil plus 100 mesh (149 microns), was then dried and submitted for gamma spectroscopy analysis. This coarse fraction was then subjected to attrition scrubbing for 15 minutes at approximately 70 to 75 percent solids. The attrition scrubbing consisted of violent agitation of the coarse fraction, forcing finer material to separate from more coarse material. The attrition scrubbed soil was then wet sieved again. The coarse fraction was dried and submitted for gamma spectroscopy analysis. The final coarse fraction as well as the combined fine fractions, initial wet sieving and wet sieving after attrition scrubbing, were sent to another laboratory for americium and isotopic plutonium analysis. For a more complete discussion of this sampling effort, see the fourth Sampling Instruction Characterization Event presented in Appendix A.

The DRI laboratory program consisted of grain-size analysis (wet sieving) of each sample, followed by gamma spectroscopy analysis. The intent of the DRI laboratory program was to confirm the ITPDL results. This confirmation was required because of the variability of the results previously experienced during site characterization. Note that the DRI soils were not attrition scrubbed prior to wet sieving, and gamma spectroscopy analysis was the only analysis conducted. The DRI wet sieving was conducted with a vibrating type of sieving system, which agitates the sample more than the ITPDL sieving system. This additional agitation may liberate more of the fine fraction than the ITPDL sieving system and less than the attrition scrubbing process. Smaller volumes of soil were wet sieved and analyzed at DRI than at the ITPDL, so the variability of the results may be slightly greater. 


\subsection{Nature and Extent of Soil Contamination}

Historical records indicate that during the Double Tracks experiment the only materials known to have been released were radioactive materials. There are no historical records indicating that significant amounts of RCRA constituents were either present or released at the Double Tracks Test Site. Therefore, this section focuses primarily on the nature and extent of radiological soil contamination at the Double Tracks Test Site. This section also describes the contaminant plume as it currently exists and demonstrates that the plume has not changed significantly since the experiment was conducted. In addition, identified contaminants of concern, estimates of the volume of contaminated soil, and a summary of isotopic ratios calculated are presented.

This section is organized as follows:

- Contaminants of concern are identified.

- Horizontal extent and vertical extent of contamination are delineated.

- Nature and extent of contamination at the ground zero area are defined.

- Results of soil volume reduction studies are presented.

- Volume of contaminated soil at the Double Tracks Test Site is estimated.

\subsection{Radiological Constituents}

This section discusses radiological constituents of concern, the Pu/Am ratio, and hot spots.

\subsubsection{Identification of Radiological Constituents of Concern}

Figure 3-1 shows the location of soil samples collected and analyzed for radionuclides during the first Double Tracks Test Site characterization event, and Table 3-1 summarizes the activities of detected radioisotopes. Surface soil samples were collected from the uppermost $5 \mathrm{~cm}$ ( $2 \mathrm{in}$.) of the soil profile (Section 2.1) and were analyzed by gamma spectroscopy using Method HASL 300 (DOE, 1992), with the exception of Am-241, isotopic plutonium, and isotopic uranium, which were analyzed by Methods NAS-NS-3006, NAS-NS-3058, and NAS-NS-3050, respectively (National Academy of Sciences [NAS], 1960, 1965, and 1962, respectively).

Figure 3-2 shows the location of hot spot sampling experiments conducted during the second characterization event, and Table 3-2 lists the radiological results for the hot spot soil samples. 


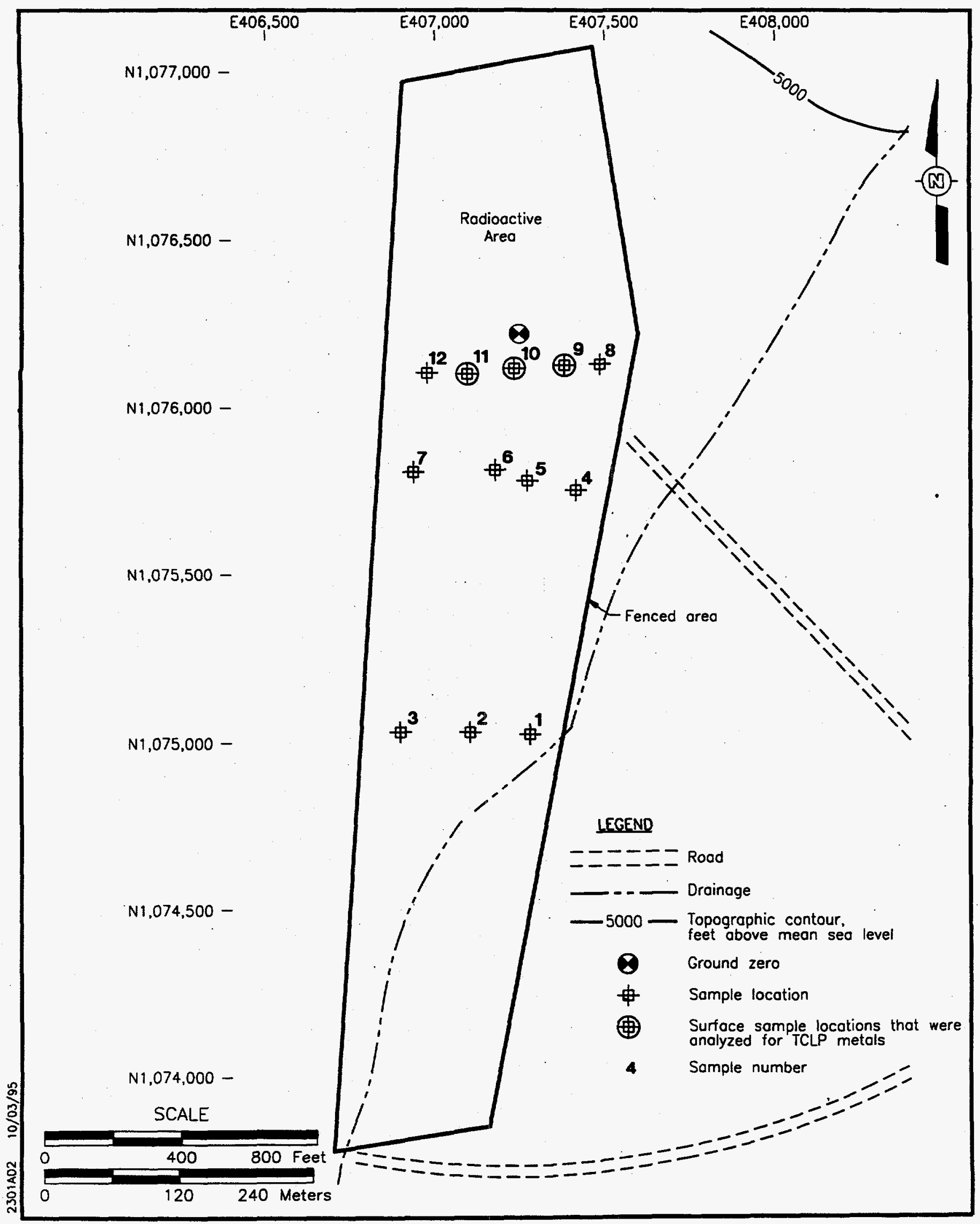

Figure 3-1

Location of Soil Samples Collected During the First Characterization Event 
Table 3-1

Radionuclide Activity in Surface Soil at the Double Tracks Test Site

(Page 1 of 2)

\begin{tabular}{|c|c|c|c|c|c|c|c|c|c|c|c|c|c|c|c|c|c|c|}
\hline Radionuclide & Ac-227 & Am-241 & $\mathrm{Bi}-214$ & Cs-137 & Co-60 & Eu-155 & $\mathrm{Pb}-210$ & $\mathrm{~Pb}-212$ & Pu-238 & $\begin{array}{c}\text { Pu-239 and } \\
\text { Pu-240 }\end{array}$ & $K-40$ & Pa-234 & Aa-226 & TI-20B & Th-232 & U-234 & $\begin{array}{c}\mathrm{U}-235 \text { and } \\
\mathrm{U}-236\end{array}$ & U-238 \\
\hline $\begin{array}{l}\text { Location } 1 \\
\text { Soil Sample } \\
\text { DT00002 }\end{array}$ & $<0.24$ & $\begin{array}{c}0.056 \pm \\
0.021\end{array}$ & $\begin{array}{c}1.40 \pm \\
0.14\end{array}$ & $\begin{array}{c}0.54 \pm \\
0.08\end{array}$ & $<0.059$ & $\begin{array}{c}0.12 \pm \\
0.07\end{array}$ & $\begin{array}{c}1.60 \pm \\
0.55\end{array}$ & $\begin{array}{c}1.97 \pm \\
0.23\end{array}$ & $\begin{array}{c}0.008 \pm \\
0.011\end{array}$ & $0.12 \pm 0.04$ & $\begin{array}{c}33.6 \pm \\
3.6\end{array}$ & $<0.10$ & $\begin{array}{c}1.32 \pm \\
0.09\end{array}$ & $\begin{array}{c}0.59 \pm \\
0.07\end{array}$ & $\begin{array}{l}1.93 \pm \\
0.020\end{array}$ & $\begin{array}{c}0.92 \pm \\
0.20\end{array}$ & $\begin{array}{c}0.073 \pm \\
0.046\end{array}$ & $\begin{array}{c}0.80 \pm \\
0.18\end{array}$ \\
\hline $\begin{array}{l}\text { Location } 1 \\
\text { Soil Sample } \\
\text { DT00002 } \\
\text { Lab Duplicale }\end{array}$ & $\begin{array}{c}1.41 \pm \\
0.34\end{array}$ & $\begin{array}{c}0.020 \pm \\
0.012\end{array}$ & $\begin{array}{c}1.28 \pm \\
0.14\end{array}$ & $\begin{array}{c}0.53 \pm \\
0.08\end{array}$ & $<0.070$ & $<0.26$ & $<113$ & $\begin{array}{c}2.03 \pm \\
0.22\end{array}$ & $\begin{array}{c}-0.004 \pm \\
0.010\end{array}$ & $0.063 \pm 0.035$ & $\begin{array}{c}35.2 \pm \\
3.8\end{array}$ & $<0.21$ & $\begin{array}{c}1.27 \pm \\
0.10\end{array}$ & $\begin{array}{c}0.64 \pm \\
0.08\end{array}$ & $\begin{array}{c}1.80 \pm \\
0.23\end{array}$ & $\begin{array}{c}0.82 \pm \\
0.18\end{array}$ & $\begin{array}{c}0.043 \pm \\
0.034\end{array}$ & $\begin{array}{c}0.51 \pm \\
0.13\end{array}$ \\
\hline $\begin{array}{l}\text { Location } 2 \\
\text { Soil Sample } \\
\text { DT00006 } \\
\end{array}$ & $<0.23$ & $\begin{array}{c}0.28 \pm \\
0.15\end{array}$ & $\begin{array}{c}1.16 \pm \\
0.13\end{array}$ & $\begin{array}{c}1.06 \pm \\
0.13\end{array}$ & $<0.052$ & $\begin{array}{c}0.13 \pm \\
0.07\end{array}$ & $\begin{array}{c}1.77 \pm \\
0.58\end{array}$ & $\begin{array}{c}1.77 \pm \\
0.15\end{array}$ & $\begin{array}{c}0.15 \pm \\
0.06\end{array}$ & $6.92 \pm 1.16$ & $\begin{array}{c}29.6 \pm \\
3.1\end{array}$ & $<0.11$ & $\begin{array}{c}1.24 \pm \\
0.09\end{array}$ & $\begin{array}{c}0.58 \pm \\
0.07\end{array}$ & $\begin{array}{c}1.68 \pm \\
0.20\end{array}$ & $\begin{array}{c}1.11 \pm \\
0.26\end{array}$ & $\begin{array}{c}0.049 \pm \\
0.044\end{array}$ & $\begin{array}{c}0.92 \pm \\
0.23\end{array}$ \\
\hline $\begin{array}{l}\text { Location } 3 \\
\text { Soil Sample } \\
\text { DT00010 }\end{array}$ & $\begin{array}{c}2.31 \pm \\
0.44\end{array}$ & $\begin{array}{c}0.089 \pm \\
0.036\end{array}$ & $\begin{array}{c}1.22 \pm \\
0.16\end{array}$ & $\begin{array}{c}1.09 \pm \\
0.16\end{array}$ & $<0.078$ & $<0.23$ & $<10.9$ & $\begin{array}{c}1.86 \pm \\
0.20\end{array}$ & $\begin{array}{c}0.012 \pm \\
0.010\end{array}$ & $0.68 \pm 0.13$ & $\begin{array}{c}29.3 \pm \\
3.4\end{array}$ & $<0.21$ & $\begin{array}{c}1.23 \pm \\
0.11\end{array}$ & $\begin{array}{c}0.68 \pm \\
0.09\end{array}$ & $\begin{array}{c}1.48 \pm \\
0.22\end{array}$ & $\begin{array}{c}1.20 \pm \\
0.27\end{array}$ & $\begin{array}{c}0.089 \pm \\
0.059\end{array}$ & $\begin{array}{c}1.16 \pm \\
0.26\end{array}$ \\
\hline $\begin{array}{l}\text { Location } 4 \\
\text { Soil Sample } \\
\text { DT00014 }\end{array}$ & $<0.20$ & $\begin{array}{c}0.009 \pm \\
0.011\end{array}$ & $\begin{array}{c}1.24 \pm \\
0.12\end{array}$ & $\begin{array}{l}1.34 \pm \\
0.15\end{array}$ & $\begin{array}{c}0.061 \pm \\
0.031\end{array}$ & $<0.11$ & $\begin{array}{c}1.66 \pm \\
0.48\end{array}$ & $\begin{array}{c}1.77 \pm \\
0.20\end{array}$ & $\begin{array}{c}-0.004 \pm \\
0.004\end{array}$ & $0.066 \pm 0.19$ & $\begin{array}{c}31.9 \pm \\
3.3\end{array}$ & $<0.093$ & $\begin{array}{c}1.19 \pm \\
0.08\end{array}$ & $\begin{array}{c}0.60 \pm \\
0.06\end{array}$ & $\begin{array}{c}1.63 \pm \\
0.17\end{array}$ & $\begin{array}{c}0.94 \pm \\
0.29\end{array}$ & $0.11 \pm 0.09$ & $\begin{array}{c}1.28 \pm \\
0.36\end{array}$ \\
\hline $\begin{array}{l}\text { Location } 4 \\
\text { Field Blank } \\
\text { DT00018 }\end{array}$ & $<0.079$ & $\begin{array}{c}0.009 \pm \\
0.018\end{array}$ & $\begin{array}{c}0.060 \pm \\
0.027\end{array}$ & $<0.015$ & $<0.016$ & $<0.034$ & $<0.26$ & $<0.028$ & $\begin{array}{c}-0.001 \pm \\
0.001\end{array}$ & $0.012 \pm 0.019$ & $<0.18$ & $<0.033$ & $\begin{array}{c}0.060 \pm \\
0.027\end{array}$ & $<0.018$ & $<0.078$ & $\begin{array}{c}0.28 \pm \\
0.19\end{array}$ & $0.07 \pm 0.10$ & $\begin{array}{c}0.23 \pm \\
0.17\end{array}$ \\
\hline $\begin{array}{l}\text { Location } 5 \\
\text { Soil Sample } \\
\text { DT00019 }\end{array}$ & $<0.23$ & $\begin{array}{c}0.21 \pm \\
0.07\end{array}$ & $\begin{array}{c}1.31 \pm \\
0.14\end{array}$ & $\begin{array}{c}0.38 \pm \\
0.06\end{array}$ & $<0.052$ & $\begin{array}{c}0.14 \pm \\
0.07\end{array}$ & $\begin{array}{c}1.43 \pm \\
0.51\end{array}$ & $\begin{array}{c}1.92 \pm \\
0.15\end{array}$ & $\begin{array}{c}0.021 \pm \\
0.032\end{array}$ & $1.42 \pm 0.33$ & $\begin{array}{c}31.3 \pm \\
3.3\end{array}$ & $<0.11$ & $\begin{array}{c}1.29 \pm \\
0.09\end{array}$ & $\begin{array}{c}0.59 \pm \\
0.07\end{array}$ & $\begin{array}{c}1.72 \pm \\
0.20\end{array}$ & $\begin{array}{c}1.12 \pm \\
0.33\end{array}$ & $\begin{array}{c}0.074 \pm \\
0.077\end{array}$ & $\begin{array}{c}0.92 \pm \\
0.29\end{array}$ \\
\hline $\begin{array}{l}\text { Location } 6 \\
\text { Soil Sample } \\
\text { DT00024 }\end{array}$ & $\begin{array}{c}1.35 \pm \\
0.29\end{array}$ & $\begin{array}{c}8.96 \pm \\
1.56\end{array}$ & $\begin{array}{c}1.26 \pm \\
0.13\end{array}$ & $\begin{array}{c}0.26 \pm \\
0.05\end{array}$ & $<0.048$ & $<0.22$ & $<110$ & $\begin{array}{c}1.86 \pm \\
0.19\end{array}$ & $\begin{array}{c}0.47 \pm \\
0.61\end{array}$ & $80.0 \pm 15.3$ & $\begin{array}{c}32.5 \pm \\
3.5\end{array}$ & $\begin{array}{c}0.20 \pm \\
0.11\end{array}$ & $\begin{array}{c}1.28 \pm \\
0.09\end{array}$ & $\begin{array}{c}0.59 \pm \\
0.07\end{array}$ & $\begin{array}{c}1.69 \pm \\
0.20\end{array}$ & $\begin{array}{c}0.90 \pm \\
0.28\end{array}$ & $0.10 \pm 0.09$ & $\begin{array}{c}0.84 \pm \\
0.26\end{array}$ \\
\hline $\begin{array}{l}\text { Location } 7 \\
\text { Soil Sample } \\
\text { DT00028 } \\
\end{array}$ & $\begin{array}{c}2.34 \pm \\
0.45\end{array}$ & $\begin{array}{c}0.007 \pm \\
0.017\end{array}$ & $\begin{array}{c}1.34 \pm \\
0.17\end{array}$ & $\begin{array}{c}0.31 \pm \\
0.07\end{array}$ & $<0.077$ & $<0.23$ & $<10.8$ & $\begin{array}{c}1.90 \pm \\
0.21\end{array}$ & $\begin{array}{c}0.004 \pm \\
0.018\end{array}$ & $0.077 \pm 0.053$ & $\begin{array}{c}31.9 \pm \\
3.6\end{array}$ & $<0.21$ & $\begin{array}{c}1.38 \pm \\
0.11\end{array}$ & $\begin{array}{c}0.64 \pm \\
0.09\end{array}$ & $\begin{array}{c}1.73 \pm \\
0.23\end{array}$ & $\begin{array}{c}0.72 \pm \\
0.24\end{array}$ & $\begin{array}{c}0.000 \pm \\
0.000\end{array}$ & $\begin{array}{c}0.68 \pm \\
0.23\end{array}$ \\
\hline $\begin{array}{l}\text { Location } 8 \\
\text { Soil Sample } \\
\text { DT00032 }\end{array}$ & $\begin{array}{c}4.46 \pm \\
0.68\end{array}$ & $\begin{array}{c}0.076 \pm \\
0.059\end{array}$ & $\begin{array}{c}1.09 \pm \\
0.16\end{array}$ & $\begin{array}{c}0.29 \pm \\
0.05\end{array}$ & $<0.053$ & $<0.17$ & $<2.34$ & $\begin{array}{c}1.88 \pm \\
0.19\end{array}$ & $\begin{array}{c}-0.012 \pm \\
0.007\end{array}$ & $0.66 \pm 0.19$ & $\begin{array}{c}30.8 \pm \\
3.5\end{array}$ & $<0.17$ & $\begin{array}{c}1.12 \pm \\
0.10\end{array}$ & $\begin{array}{c}0.61 \pm \\
0.07\end{array}$ & $\begin{array}{c}1.72 \pm \\
0.28\end{array}$ & $\begin{array}{c}1.13 \pm \\
0.31\end{array}$ & $\begin{array}{c}0.077 \pm \\
0.070\end{array}$ & $\begin{array}{c}1.07 \pm \\
0.30\end{array}$ \\
\hline
\end{tabular}


Table 3-1

Radionuclide Activity in Surface Soil at the Double Tracks Test Site

(Page 2 of 2)

\begin{tabular}{|c|c|c|c|c|c|c|c|c|c|c|c|c|c|c|c|c|c|c|}
\hline Radionuclide & Ac-227 & $A m-241$ & Bi-214 & Cs-137 & Co-60 & Eu-155 & $\mathrm{Pb}-210$ & $\mathrm{~Pb}-212$ & $P u-238$ & $\begin{array}{l}\text { Pu-239 and } \\
\text { Pu-240 }\end{array}$ & $K-40$ & $\mathrm{~Pa}-234$ & Ra-226 & $\mathrm{TI}-208$ & Th-232 & $U-234$ & $\begin{array}{c}\mathrm{U}-235 \text { and } \\
\mathrm{U}-236\end{array}$ & U-238 \\
\hline $\begin{array}{l}\text { Location } 9 \\
\text { Soil Sample } \\
\text { DT00036 }\end{array}$ & $\begin{array}{c}1.52 \pm \\
0.31\end{array}$ & $\begin{array}{c}2.27 \pm \\
0.45\end{array}$ & $\begin{array}{l}1.29 \pm \\
0.13\end{array}$ & $\begin{array}{c}0.41 \pm \\
0.06\end{array}$ & $<0.049$ & $<0.21$ & $<104$ & $\begin{array}{c}1.88 \pm \\
0.19\end{array}$ & $\begin{array}{c}0.18 \pm \\
0.06\end{array}$ & $29.3 \pm 4.6$ & $\begin{array}{c}32.6 \pm \\
3.5\end{array}$ & $<0.18$ & $\begin{array}{c}1.36 \pm \\
0.09\end{array}$ & $\begin{array}{c}0.62 \pm \\
0.07\end{array}$ & $\begin{array}{c}1.74 \pm \\
0.21\end{array}$ & $\begin{array}{c}0.81 \pm \\
0.19\end{array}$ & $\begin{array}{c}0.046 \pm \\
0.039\end{array}$ & $\begin{array}{c}0.82 \pm \\
0.19\end{array}$ \\
\hline $\begin{array}{l}\text { Location } 10 \\
\text { Soil Sample } \\
\text { DTO0040 }\end{array}$ & $\begin{array}{c}4.34 \pm \\
0.67\end{array}$ & $17.1 \pm 3.1$ & $\begin{array}{c}1.15 \pm \\
0.17\end{array}$ & $\begin{array}{c}0.33 \pm \\
0.06\end{array}$ & $<0.060$ & $<0.19$ & $17.4 \pm 6.1$ & $\begin{array}{c}1.98 \pm \\
0.20\end{array}$ & $\begin{array}{c}2.40 \pm \\
1.38\end{array}$ & $341 \pm 58$ & $\begin{array}{c}32.1 \pm \\
3.7\end{array}$ & $\begin{array}{c}0.33 \pm \\
0.13\end{array}$ & $\begin{array}{c}1.18 \pm \\
0.11\end{array}$ & $\begin{array}{c}0.69 \pm \\
0.08\end{array}$ & $\begin{array}{c}1.95 \pm \\
0.31\end{array}$ & $\begin{array}{c}1.11 \pm \\
0.25\end{array}$ & $\begin{array}{c}0.080 \pm \\
0.050\end{array}$ & $\begin{array}{c}0.86 \pm \\
0.20\end{array}$ \\
\hline $\begin{array}{l}\text { Location } 11 \\
\text { Soil Sample } \\
\text { DT00045 }\end{array}$ & $<0.24$ & $\begin{array}{c}0.081 \pm \\
0.052\end{array}$ & $\begin{array}{c}1.24 \pm \\
0.16\end{array}$ & $\begin{array}{c}0.29 \pm \\
0.05\end{array}$ & $<0.057$ & $<0.11$ & $\begin{array}{c}1.66 \pm \\
0.55\end{array}$ & $\begin{array}{c}1.69 \pm \\
0.17\end{array}$ & $\begin{array}{c}0.007 \pm \\
0.016\end{array}$ & $2.33 \pm 0.47$ & $\begin{array}{c}32.0 \pm \\
3.3\end{array}$ & $<0.11$ & $\begin{array}{c}1.28 \pm \\
0.09\end{array}$ & $\begin{array}{c}0.67 \pm \\
0.08\end{array}$ & $\begin{array}{c}1.84 \pm \\
0.20\end{array}$ & $\begin{array}{c}1.15 \pm \\
0.39\end{array}$ & $0.57 \pm 0.28$ & $\begin{array}{c}1.11 \pm \\
0.38\end{array}$ \\
\hline $\begin{array}{l}\text { Location } 12 \\
\text { Soil Sample } \\
\text { DTO0049 }\end{array}$ & $<0.25$ & $\begin{array}{c}0.053 \pm \\
0.052\end{array}$ & $\begin{array}{c}1.38 \pm \\
0.14\end{array}$ & $\begin{array}{c}0.46 \pm \\
0.07\end{array}$ & $<0.046$ & $<0.12$ & $\begin{array}{c}1.39 \pm \\
0.49\end{array}$ & $\begin{array}{c}1.94 \pm \\
0.15\end{array}$ & $\begin{array}{c}0.034 \pm \\
0.026\end{array}$ & $2.23 \pm 0.39$ & $\begin{array}{c}33.5 \pm \\
3.3\end{array}$ & $\begin{array}{c}0.17 \pm \\
0.09\end{array}$ & $\begin{array}{c}1.34 \pm \\
0.09\end{array}$ & $\begin{array}{c}0.61 \pm \\
0.07\end{array}$ & $\begin{array}{c}1.75 \pm \\
0.19\end{array}$ & $\begin{array}{c}1.11 \pm \\
0.24\end{array}$ & $0.11 \pm 0.06$ & $\begin{array}{c}0.94 \pm \\
0.21\end{array}$ \\
\hline
\end{tabular}

$\stackrel{\omega}{a}{ }^{a}$ Field blank is sea sand.

Notes:

All soil samples collected from a depth interval of 0 to $5 \mathrm{~cm}(0$ to $2 \mathrm{in}$.)

See Figure 3-1 for soil sample locations.

All activities are in $\mathrm{pCi} / \mathrm{g}$ (picocuries per gram) followed by the uncertainty reported as the 2 sigma error.

All activjties were determined by gamma spectroscopy (Method HSL300), except the following:

AM-241 by Method NAS-NS-3006
Pu238, Pu239, Pu240 by Method NAS-NS-3058
U-238 by Method NAS-NS-3050

$<=$ A less than symbol " $<$ " indicates that the analyte was present above the instrument detection limit at an activity levels less than the value shown. 


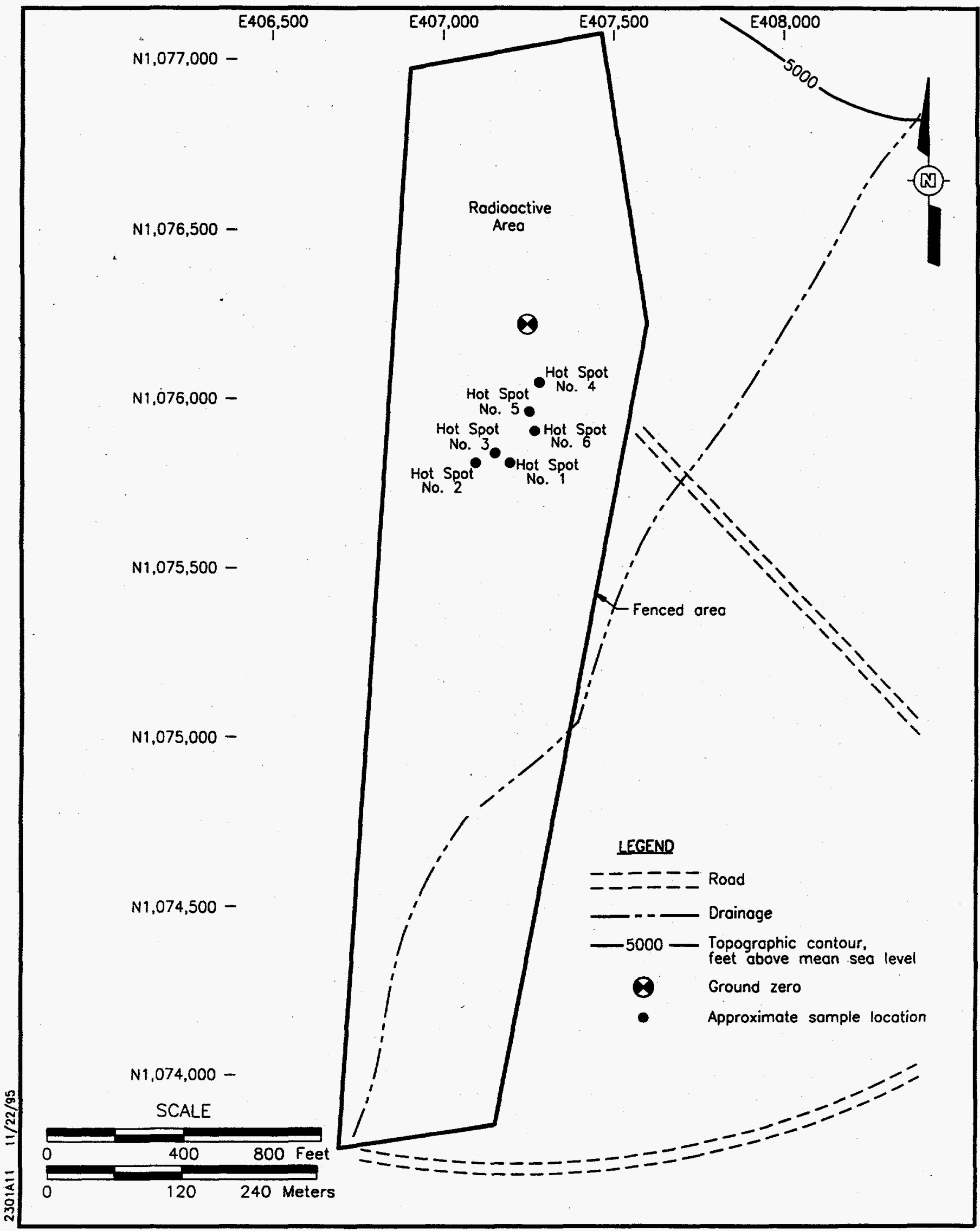

Figure 3-2

Location of Hot Spot Soil Profile Samples Collected During the Second Characterization Event 


\section{Table 3-2}

Radionuclide Activities in Surface Soil Samples Collected from Hot Spot Locations

\begin{tabular}{|c|c|c|c|c|c|c|c|}
\hline Radionuclide & $\begin{array}{c}\text { Hot Spot } 1 \\
\text { Soil Sample } \\
\text { DT00100 }\end{array}$ & $\begin{array}{l}\text { Hot Spot } 1 \\
\text { Soil Sample } \\
\text { Lab. Dup. } \\
\text { DT00100 }\end{array}$ & $\begin{array}{c}\text { Hot Spot } 2 \\
\text { Soil Sample } \\
\text { DT00101 }\end{array}$ & $\begin{array}{c}\text { Hot Spot } 3 \\
\text { Soil Sample } \\
\text { DT00102 }\end{array}$ & $\begin{array}{c}\text { Hot Spot } 4 \\
\text { Soil Sample } \\
\text { DT00103 }\end{array}$ & $\begin{array}{l}\text { Hot Spot } 5 \\
\text { Soil Sample } \\
\text { DT00104 }\end{array}$ & $\begin{array}{c}\text { Hot Spot } 6 \\
\text { Soil Sample } \\
\text { DT00105 }\end{array}$ \\
\hline $\begin{array}{l}\text { Americium-241 } \\
\text { (pCi/g) }\end{array}$ & $734 \pm 163$ & $656 \pm 154$ & $567 \pm 133$ & $64.6 \pm 25.0$ & $783 \pm 172$ & $29.6 \pm 12.1$ & $10.1 \pm 7.3$ \\
\hline $\begin{array}{l}\text { Plutonium-238 } \\
\text { (pCi/g) }\end{array}$ & $90.0 \pm 22.5$ & $101 \pm 27$ & $95.0 \pm 28.5$ & $9.45 \pm 7.51$ & $91.0 \pm 23.8$ & $10.9 \pm 8.2$ & $6.1 \pm 6.7$ \\
\hline $\begin{array}{l}\text { Plutonium-239/240 } \\
\text { (pCi/g) }\end{array}$ & $12,000 \pm 2,030$ & $\begin{array}{c}10,600 \pm \\
1,870\end{array}$ & $10,800 \pm 2,010$ & $998 \pm 200$ & $11,900 \pm 2,060$ & $775 \pm 158$ & $183 \pm 48$ \\
\hline $\begin{array}{l}\text { Total Uranium } \\
(\mu \mathrm{g} / \mathrm{g})\end{array}$ & $3.50 \pm 0.37$ & $3.59 \pm 0.38$ & $2.63 \pm 0.27$ & $3.92 \pm 0.41$ & $3.41 \pm 0.36$ & $2.55 \pm 0.27$ & $2.12 \pm 0.22$ \\
\hline $\begin{array}{l}\text { Plutonium-238/240 } \\
\text { to Americium-241 } \\
\text { Ratio }\end{array}$ & 16.3 & 16.2 & 19.0 & 15.4 & 15.2 & 26.2 & 18.1 \\
\hline
\end{tabular}

Notes:

See Figure 3-2 for hot spot locations.

All activities are reported in picocuries per gram except total uranium which is reported in micrograms per gram $(\mu \mathrm{g} / \mathrm{g}$ ) or parts per million (ppm).

All values followed by the uncertainty reported as a 2 sigma error 
The uppermost $2.5 \mathrm{~cm}$ ( $1 \mathrm{in}$.) of soil was collected at each location for analysis of Am-241, isotopic plutonium, and total uranium. Any metallic fragments found in the soil were removed before the soil was placed into sample containers. The analytical methods for americium and plutonium were as specified above, and American Society for Testing and Materials (ASTM) Method 5174-91 (ASTM, 1991) was used for the total uranium analysis.

The following are potential sources of radionuclides in the soil at the Double Tracks Test Site:

- The Double Tracks experiment

- Fallout from nuclear weapons atmospheric testing

- Natural terrestrial sources

Naturally occurring radionuclides in soil include potassium-40 (K-40), uranium isotopes (e.g., U-234, U-235, and U-238); thorium isotopes (e.g., Th-232), and decay products of uranium and thorium (e.g., radium-226 [Ra-226]). These radionuclides generally have very long half-lives and have been present since the formation of the earth. Man-made radionuclides are ubiquitous in surface soil because of fallout from atmospheric testing of nuclear weapons that began in the 1940s and continued into the 1960s. Examples of these radionuclides are cesium-137 (Cs-137), cobalt-60 (Co-60), and europium-155 (Eu-155). Although the Double Tracks Test Site is not directly downwind of most of the NTS atmospheric testing, it was downwind of a few and did receive a minor component of fallout from the NTS, as well as global fallout.

Table 3-3 lists background levels of radionuclides in surface soil derived from two studies. The first study evaluated background activities of several radionuclides in the uppermost $5 \mathrm{~cm}$ ( 2 in.) of surface soil at selected undisturbed sample locations in south-central Nevada and southeastern California (McArthur and Miller, 1989). Most of the sample locations were within $160 \mathrm{~km}$ (100 mi) of the Double Tracks Test Site. The activity range, mean activity, upper 95 percent confidence limit for the mean, and the standard deviation are given for each radionuclide. Lognormal-distributions are assumed. The second study was a statistical evaluation of historical background data for samples collected at Sandia National Laboratories/New Mexico in Albuquerque, New Mexico (IT, 1994). The activity range and geometric mean soil activity are listed for each radionuclide. Mean activities are given as arithmetic means of lognormal distributions for the first background study and as geometric means of lognormal distributions for 
Table 3-3

Background Radioactivity in Surface Soil

\begin{tabular}{|c|c|c|c|c|c|c|}
\hline \multirow[b]{2}{*}{ Radionuclide } & \multicolumn{4}{|c|}{ South-Central Nevada and Southeastern California ${ }^{a}$} & \multicolumn{2}{|c|}{$\begin{array}{c}\text { Sandia National } \\
\text { Laboratories; Albuquerque, } \\
\text { New Mexico }\end{array}$} \\
\hline & $\begin{array}{l}\text { Range } \\
\text { (pCi/g) }\end{array}$ & $\begin{array}{l}\text { Mean } \\
(\mathrm{pCi} / g)\end{array}$ & $\begin{array}{c}\text { Standard } \\
\text { Deviation } \\
\text { (pCi/g) }\end{array}$ & $\begin{array}{c}\text { Upper } 95 \\
\text { percent } \\
\text { Confidence } \\
\text { Limit for } \\
\text { the Mean } \\
\text { (pCi/g) }\end{array}$ & $\begin{array}{l}\text { Range } \\
\text { (pCi/g) }\end{array}$ & $\begin{array}{c}\text { Geometric } \\
\text { Mean } \\
\text { (pCi/g) }\end{array}$ \\
\hline Bismuth-214 & ND & ND & ND & ND & 0.43 to 1.3 & 0.62 \\
\hline Cesium-137 & 0.203 to 0.605 & 0.369 & 0.114 & 0.448 & 0.004 to 1.8 & 0.191 \\
\hline Lead-210 & ND & ND & ND & ND & 0.5 to 12 & 3.5 \\
\hline Lead-212 & ND & ND & ND & ND & 0.5 to 1.4 & 0.69 \\
\hline $\begin{array}{l}\text { Plutonium- } \\
239 / 240\end{array}$ & 0.013 to 0.092 & 0.034 & 0.026 & 0.090 & ND & ND \\
\hline Potassium-40 & 10.6 to 29.3 & 19.3 & 5.0 & 22.6 & 0.19 to 31 & 17.6 \\
\hline Radium-226 & ND & ND & ND & ND & 0.51 to 2.46 & 1.13 \\
\hline Thorium-232 & 0.61 to 1.51 & 1.24 & 0.37 & 1.49 & 0.23 to 1.16 & 0.79 \\
\hline Uranium-234 & ND & ND & ND & ND & 0.8 to 1.0 & 0.9 \\
\hline Uranium-235 & ND & ND & ND & ND & 0.108 to 0.156 & 0.125 \\
\hline Uranium-238 & 0.94 to 2.08 & 1.40 & 0.34 & 1.62 & 0.7 to 1.1 & 0.9 \\
\hline Total Uranium & ND & ND & ND & ND & 0.005 to 4.66 & 0.992 \\
\hline
\end{tabular}

a Background from six locations in south-central Nevada and southeastem California (McArthur and Miller, 1989)

Background from samples collected at Sandia National Laboratories/New Mexico, Albuquerque, New Mexico (IT, 1994)

Notes:

All values are in picocuries per gram except total uranium which is in $\mu \mathrm{g} / \mathrm{g} \mathrm{ppm}$.

ND = No data available

All statistical results assume a lognormal distribution.

the second study. Although these are different statistical measures, they are comparable for background data. For some of the naturally occurring radioisotopes listed in Table 3-3 (e.g., bismuth-214 [Bi-214] and lead-210 [Pb-210]), the wide activity range is indicative of the wide variety of geologic parent materials. 
Double Tracks surface soil radionuclide sample results (Tables 3-1 and 3-2) were compared with background (Table 3-3). With the exception of americium and plutonium, the radionuclides detected in Double Tracks surface soil are similar to background and are either naturally occurring or due to fallout.

The observed activity of $\mathrm{K}-40$, Th-232, and $\mathrm{Pb}-212$ in Double Tracks surface soil slightly exceeds background. These isotopes occur naturally and the elevated activity is likely due to differences in the composition of the soil parent material. Rocks that are silica-rich, such as those present at Double Tracks, are enriched in potassium, thorium, and uranium relative to other rock types (Faure, 1986; Krauskopf, 1979).

The ratio of intermediate daughter radioisotopes to their parent isotopes strongly suggests that some radionuclides detected in soil from Double Tracks are naturally occurring. Assuming no other source of isotopes, the activity ratios for the previously identified radionuclides detected in Double Tracks soil should be as follows:

- The activity of daughters $\mathrm{U}-234, \mathrm{Ra}-226, \mathrm{Bi}-214$, and $\mathrm{Pb}-210$ should be approximately equal to the activity of parent isotope U-238.

- The activity of U-235 and actinium-227 (Ac-227) should be approximately equal.

- The activity of daughter $\mathrm{Pb}-212$ should be approximately equal to that of parent isotope Th-232, and the activity of daughter thallium-208 (Tl-208) should be approximately 36 percent of Th-232.

Evaluation of the data listed in Table 3-1 shows that, in general, considering the 2-standarddeviation counting errors, the isotopic activity relationships discussed above are approximated in Double Tracks soil samples and, thus, daughter radioisotopes are generally in equilibrium with naturally occurring parent isotopes. Although uranium reportedly was present in the test device (Section 1.2), a comparison with background and evaluation of isotopic ratios (e.g., uranium versus Pu-239/240, Figure 3-3) indicates that uranium contamination either is not present or is not distinguishable from background levels (Figure 3-3).

The data in Tables 3-1 and 3-2 indicate that surface soil at some sample locations at the Double Tracks Test Site is contaminated with $\mathrm{Pu}-238, \mathrm{Pu}-239 / 240$, and Am-241. This is consistent with the results of previous investigations discussed in Section 1.4. Also consistent with the results of previous investigations, the contamination was found to be highly variable over relatively small distances based on an analysis of discrete soil samples. In general, the sample locations south of 


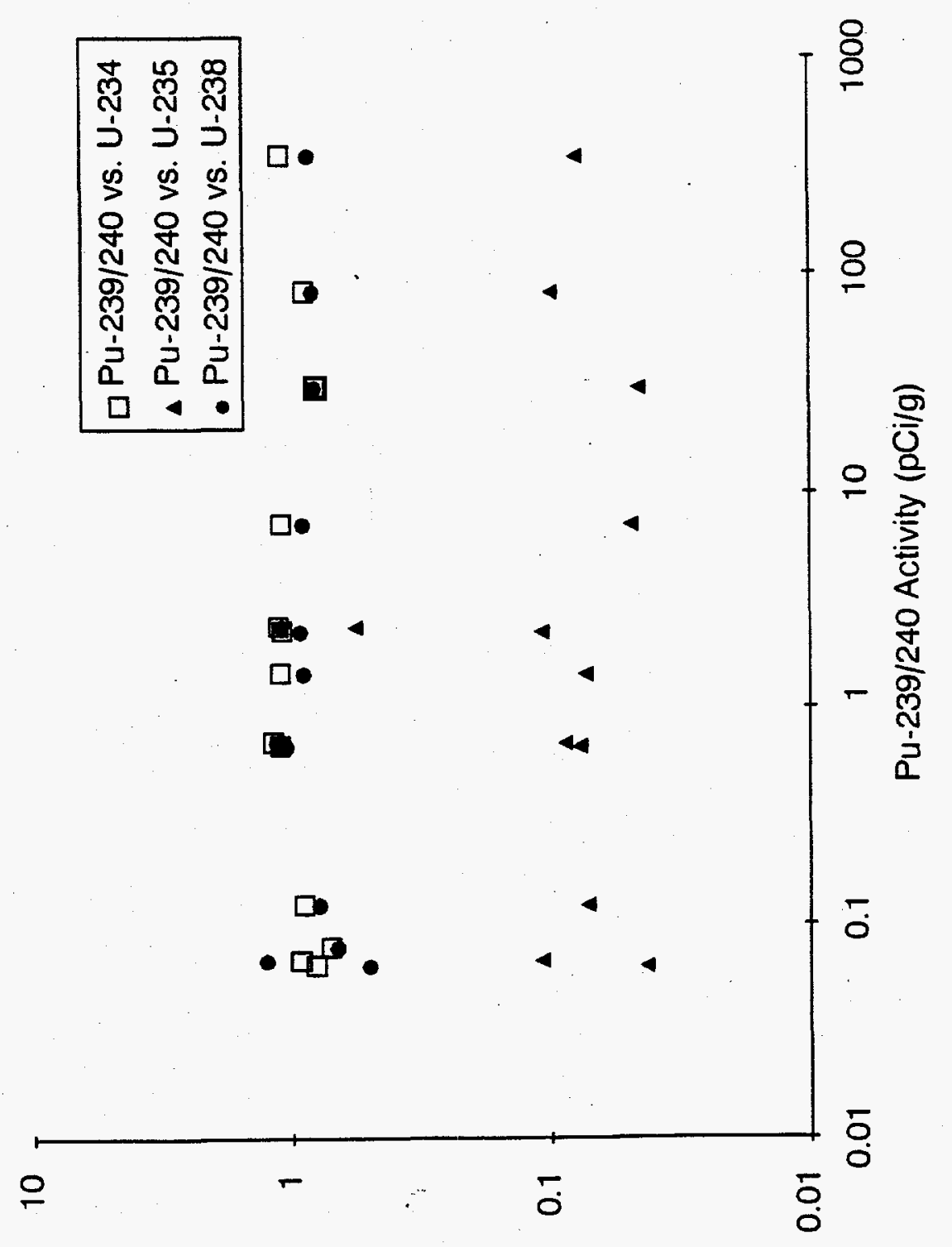

(6/!Od) R!!n!ฺจ әdolos| un!ueın

Figure 3-3

Uranium Isotope Versus Plutonium-239/240 Activity in Double Tracks Surface Soil 
ground zero and the sample locations closest to ground zero should be the most contaminated. For the first characterization event, samples from Locations 6,9 , and 10 exhibited the highest plutonium and americium levels (Table 3-1 and Figure 3-1).

Table 3-4 summarizes the information presented above and shows the most probable source of each radioisotope detected in Double Tracks soil samples. Laboratory analytical data for soil samples from characterization events 1 and 2 are presented in Appendix C.

Table 3-4

Source of Radionuclides in Double Tracks Surface Soil

\begin{tabular}{||l|l||}
\hline \multicolumn{1}{|c|}{ Source } & \multicolumn{1}{|c|}{ Radionuclides } \\
\hline \hline Double Tracks test event & americium-241, plutonium-238, plutonium-239/240 \\
\hline Fallout from atmospheric nuclear testing & cesium-137, cobalt-60, europium-155 \\
\hline Natural terrestrial radioactivity & potassium-40 \\
\cline { 2 - 3 } & thorium-232 and decay products: lead-212, thallium-208 \\
\cline { 2 - 3 } & uranium-235 and decay product: actinium-227 \\
\cline { 2 - 3 } & $\begin{array}{l}\text { uranium-238 and decay products: uranium-234, } \\
\text { protactinium-234, radium-226, bismuth-214, } \\
\text { lead-210 }\end{array}$ \\
\hline
\end{tabular}

\subsubsection{Plutonium/Americium Isotopic Ratio}

Figure 3-4 shows the calculated Pu-239/240 to Am-241 activity ratio, using known decay rates of plutonium and americium, starting with the known initial experiment isotopic ratios (Table 1-1). Based on these calculations, the theoretical isotopic ratio of $\mathrm{Pu}-239 / 240$ to Am-241 should be between 17 and 18 in 1995 . Based on laboratory results from soil samples collected during the first characterization event, the $\mathrm{Pu}-239 / 240$ to $\mathrm{Am}-241$ activity ratio was calculated to be 17.8 . The Am-241 versus $\mathrm{Pu}-239 / 240$ activities for these samples are shown in Table 3-5. This ratio is suspect because many of the isotopic results were at or near the laboratory detection limit. The linear regression standard deviation was calculated to be 12.4 which also indicated that the activity ratio is variable between sampling locations. 


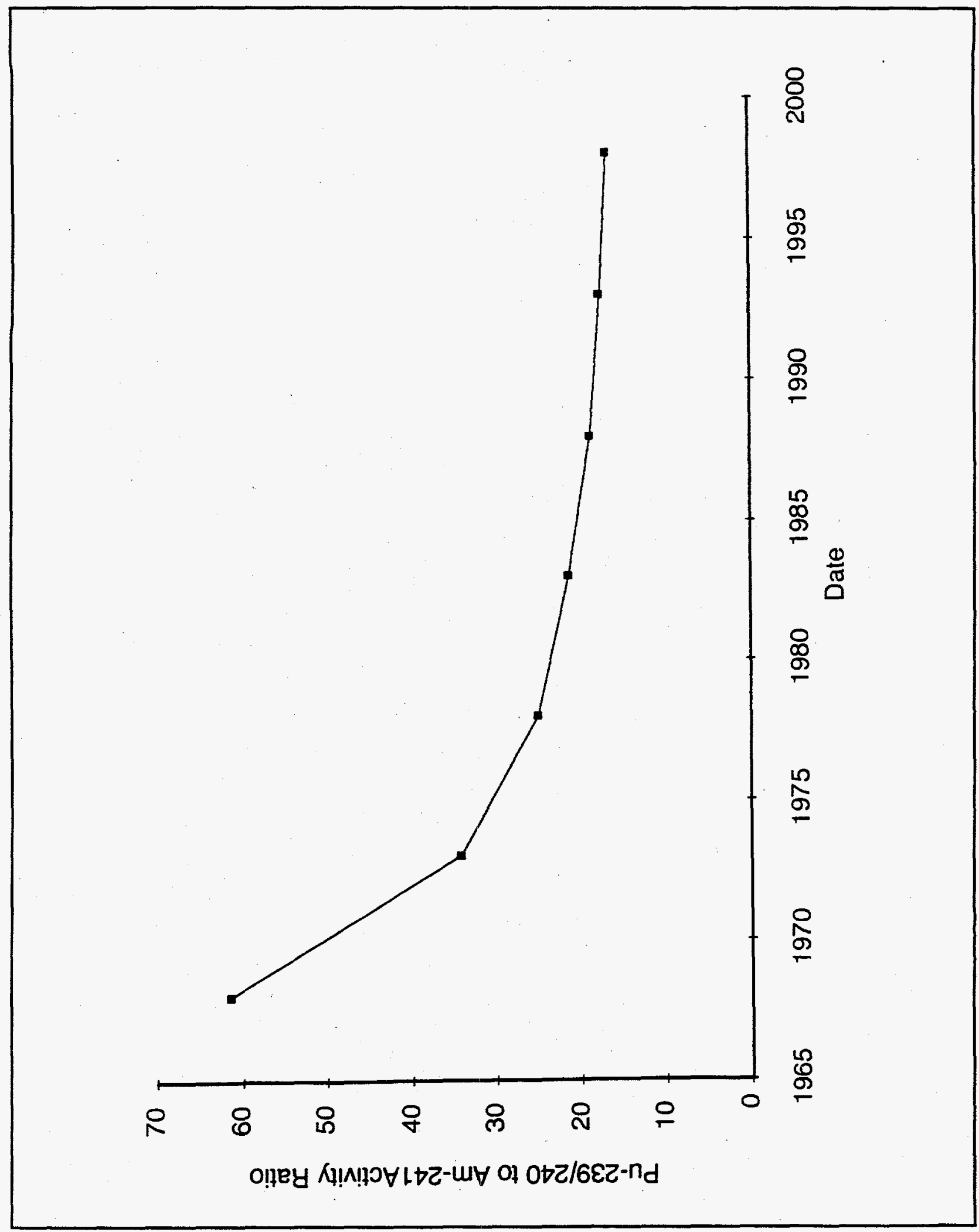

Figure 3-4

Activity Ratio of Plutonium-239/240 to Americium-241 in

Double Tracks Surface Soil (Assuming Negligible Initial Americium-241 Ingrowth) 


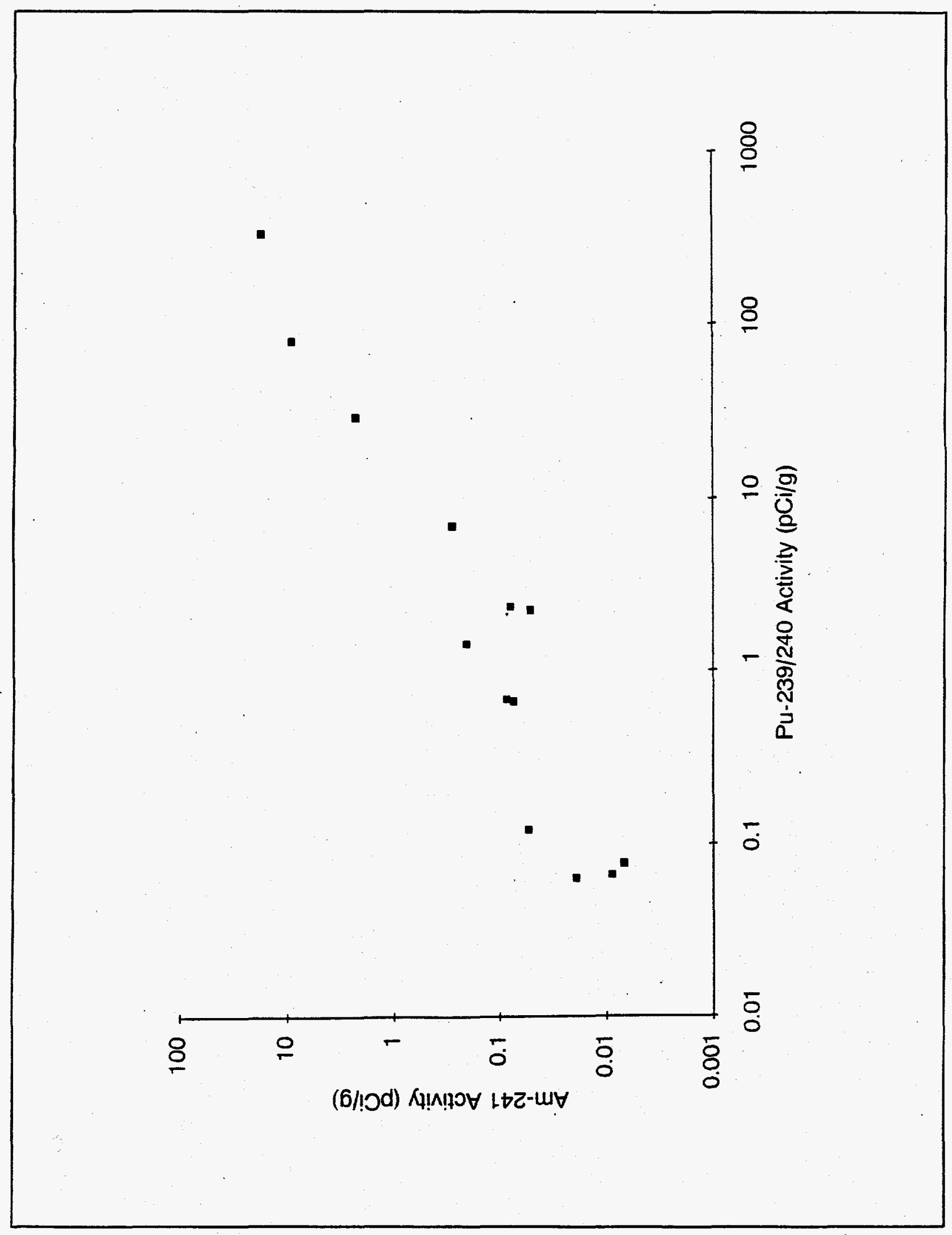

Figure 3-5

Americium-241 Versus Plutonium-239/240 Activity in Double Tracks Surface Soil 
One of the goals of the second characterization event was to more accurately determine the isotopic ratio. To accomplish this, additional soil samples were collected from areas that were known to have relatively high activities based on in situ field measurements (Section 2.2.2). The rational behind this was to have the soil samples contain enough plutonium and americium so the results would not be near the laboratory detection limit. It was assumed that these samples would yield more accurate activities and consequently more accurate isotopic ratios could be calculated. The isotopic laboratory results are presented in Table 3-2. As presented in this table, only three of the six samples indicate significant activities. The $\mathrm{Pu}-239 / 240$ to Am-241 ratios ranged from 15.2 to 26.2 and averaged 18.6, with a standard deviation of 4.0. Excluding one high activity ratio, which may be an outlier, the $\mathrm{Pu}-239 / 240$ to $\mathrm{Am}-241$ ratio is 16.7 with a standard deviation of 1.5. While the second characterization event soil sample results, and isotopic ratios, are more reasonable and closer to the theoretically calculated isotopic ratio, it was determined that the isotopic ratio was still not known to a high enough accuracy using only soil sample isotopic laboratory analysis.

After the first soil sampling event it had become apparent that soil sample laboratory analytical results were inconsistent. Therefore, in situ isotopic radiation measurements were also made during the second characterization event to assist in determining the isotopic ratios. An in depth discussion of the measuring equipment and techniques as well as the results are presented in Appendix B, in the report titled "In Situ Radiological Surveying at the Double Tracks Site," in Section 6.2 titled "Experiment \#2 - Pu: Am Ratio Measurements" (Riedhauser and Tipton, 1996). In this section the theoretical $\mathrm{Pu}-239 / 240$ to $\mathrm{Am}-241$ ratio was calculated to be 13.71 which, when adding the Am-241 yields a total transuranic (TRU) to Am-241 ratio of 14.71. In situ measurements were made at locations identified to have elevated activities, using two independent methods and two sets of instruments. The rational for the duplication was to cross check the measurements and isotopic ratio calculations. There was general agreement between the independent methods and the theoretical isotopic ratio calculated. This agreement is notable because different detectors, counting times and methods were used to reduce the data. Results of the in situ measurements yielded similar isotopic ratios with relatively low standard deviations. The in situ measurements discussion contained in Appendix B concludes by stating that the isotopic ratio of 16 is recommended to determine the activity of plutonium at the site given the Am-241 measurement. This is approximately 10 percent higher that the theoretical prediction and provides a reasonable, conservative, margin of error. An isotopic ratio of 16 was used in the contaminant analysis at the Double Tracks Test Site presented in this document. 


\subsubsection{Radiological Hot Spots}

Hot spots are discrete areas within the Double Tracks exclusion zone that exhibited elevated radioactivity relative to the surrounding area. During the second and third characterization events, in situ radiological surveys were conducted at the Double Tracks Test Site to identify hot spots. To reduce potential bias in the systematic in situ radiological survey, metallic fragments (derived from the test device or other materials) were located and removed before conducting the systematic survey. The fragments were also removed from hot spot locations prior to collection of the hot spot soil samples discussed (Section 3.1.1). When soil samples were split in the field, the activity of both sample splits was generally similar (Section 2.2.2). However, in one instance the radioactive contamination did not split equally and the difference in the activity of the splits was significant. This was probably due to the presence of a small, highly radioactive particle.

As part of the third characterization event effort, metallic fragments and hot spot soil were weighed and the metal fragments were photographed. The Am-241 activity was measured in the field using a collimated HPGe detector. Table 3-5 presents the resulting data for the fragments and hot spot soil. Following characterization, the metallic fragments and soil were placed in a secure container inside the Double Tracks exclusion zone. Using the definition set forth in Title 40, Code of Federal Regulations (CFR), Part 191.02 (U.S. Environmental Protection Agency [EPA], 1993), the fragments were classified as TRU material because the activity exceeds 100 nanocuries ( 0.100 microcuries) per gram.

\subsection{Nonradiological Constituents}

This section addresses the nonradiological constituents detected in the Double Tracks Test Site surface soil.

\subsubsection{Metals}

Nine surface soil samples collected during the first characterization event were analyzed for TAL metals using the EPA Contract Laboratory Program statement of work for inorganics (EPA, 1990a). The samples were collected from the uppermost vertical profile interval ( 0 to $5 \mathrm{~cm}$ [0 to 2 in.]) at Locations 1 through 8 and Location 12 (Figure 3-1). Table 3-6 lists the concentrations of metals in these soil samples. 
Table 3-5

Field Collimated HPGe Detector Measurements of Metal Fragments and Hot Spot Soil

\begin{tabular}{|c|c|c|c|c|c|c|c|}
\hline $\begin{array}{l}\text { Sample } \\
\text { Number }\end{array}$ & Sample Type & $\begin{array}{c}\text { Activity } \\
\text { One Side } \\
\text { Am-2\&1 } \\
(\mu \mathrm{Ci})\end{array}$ & $\begin{array}{c}\text { Activity } \\
\text { Other Side } \\
\text { Am-241 } \\
(\mu \mathrm{Ci})\end{array}$ & $\begin{array}{c}\text { Total } \\
\text { Activity } \\
\text { Am-241 } \\
(\mu \mathrm{Ci})\end{array}$ & $\begin{array}{l}\text { Weight } \\
\text { (grams) }\end{array}$ & $\begin{array}{c}\text { Activity/ } \\
\text { mass } \\
\text { Am-241 } \\
(\mu \mathrm{Ci} / g)^{C}\end{array}$ & $\begin{array}{c}\text { TRU }^{\mathrm{a}} \\
\text { Activity/ } \\
\text { mass } \\
(\mu \mathrm{Cl} / \mathrm{g})\end{array}$ \\
\hline 1 & Metal Fragment & 143.7 & 179.5 & $323.2^{d}$ & 33.25 & 9.700 & 156.000 \\
\hline 2 & Metal Fragment & 71.4 & 89.0 & $160.4^{d}$ & 30.68 & 5.200 & 84.000 \\
\hline 3 & Metal Fragment & 357.1 & 255.5 & $612.6^{d}$ & 254.01 & 2.400 & 39.000 \\
\hline 4 & Metal Fragment & 318.3 & 366.1 & $684.4^{d}$ & 316.40 & 2.200 & 35.000 \\
\hline 5 & Metal Fragment & 167.0 & 144.5 & $311.5^{d}$ & 124.12 & 2.500 & 40.000 \\
\hline 6 & Metal Fragment & 157.8 & 211.3 & $369.1^{d}$ & 58.87 & 6.300 & 100.000 \\
\hline 7 & Metal Fragment & 54.2 & 54.2 & $108.4^{d}$ & 13.41 & 8.100 & 130.000 \\
\hline 8 & Hot Spot Soil & 2.5 & 3.8 & $6.3^{d}$ & 796.62 & 0.008 & 0.127 \\
\hline 9 & Hot Spot Soil ${ }^{e}$ & 8.2 & 6.0 & $14.2^{d}$ & 746.97 & 0.019 & 0.304 \\
\hline 10 & Metal Fragment & 106.2 & 120.4 & $226.6^{d}$ & 95.55 & 2.400 & 38.000 \\
\hline 11 & Metal Fragment & 17.7 & 17.6 & $35.3^{d}$ & 21.33 & 1.700 & 27.000 \\
\hline 12 & Metal Fragment & 49.6 & 54.8 & $104.4^{d}$ & 2.40 & 43.500 & 696.000 \\
\hline 13 & Metal Fragment & 87.7 & 74.3 & $162.0^{f}$ & 107.36 & 1.500 & 24.000 \\
\hline 14 & Metal Fragment & 123.3 & 123.3 & $246.6^{f}$ & 39.78 & 6.200 & 99.000 \\
\hline 15 & Metal Fragment & 38.5 & 47.7 & $86.2^{f}$ & 17.38 & 5.000 & 80.000 \\
\hline S1 & Hot Spot Soil ${ }^{9}$ & 2.3 & 2.4 & $4.7^{f}$ & 588.41 & 0.008 & 0.128 \\
\hline S2 & Hot Spot Soil $^{h}$ & 5.9 & 6.3 & $12.2^{f}$ & 240.87 & 0.051 & 0.816 \\
\hline S3 & Hot Spot Soil & 4.6 & 5.0 & $9.6^{f}$ & 297.77 & 0.032 & 0.512 \\
\hline S4 & Hot Spot Soil & 5.8 & 5.7 & $11.5^{f}$ & 345.86 & 0.033 & 0.528 \\
\hline
\end{tabular}

Assumed a transuranic (TRU) ratio of 16 (Pu-239 + Pu-240 + Pu-241 + Am-241/Am-241)

Microcurie

Microcurie per gram

Subtracted background equivalent to $5.4 \mu \mathrm{Ci}$ from each side of metal fragment/soil

Ground zero mound vicinity (surface soil)

Subtracted background equivalent of $1.3 \mu \mathrm{Ci}$ from each side of metal fragment/soil

${ }_{9}^{9}$ Approximately 18 meters northeast of ground zero (surface soil)

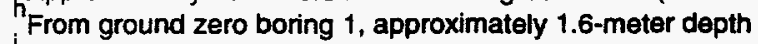

Approximately 30 meters east of ground zero (surface soil)

Approximately 46 meters east of ground zero (surface soil)

Note: For samples of hot spot soil, an actual activity will be closer to that from only one side based on sample geometry. This will be approximately half the transuranic activity/mass quoted in the table.

TRU material, as defined by DOE Order $5820.2 \mathrm{~A}$, is $0.1 \mu \mathrm{Ci} / \mathrm{g}\left(10^{5} \mathrm{pCi} / \mathrm{g}\right)$. 
Predominant metals (exceeding 1,000 milligrams per kilogram [mg/kg]) in Double Tracks surface soil are the typical rock-forming elements: calcium, aluminum, iron, magnesium, and potassium. Secondary elements (exceeding $100 \mathrm{mg} / \mathrm{kg}$ ) are barium, manganese, and sodium. Trace elements (less than $100 \mathrm{mg} / \mathrm{kg}$ ) are arsenic, beryllium, chromium, cobalt, copper, lead, nickel, vanadium, and zinc. Antimony, cadmium, selenium, silver, and thallium concentrations are all below detection limits; mercury is below the detection limit in all but one sample (Table 3-6).

The Double Tracks metal results are typical of desert soil developed from siliceous and intermediate volcanic parent material. To determine if any metal concentrations were anomalous, an outlier test was performed on the data set. The test method used is from the EPA guidance document Statistical Analysis of Ground-Water Monitoring Data at RCRA Facilities (EPA, 1989) and is based on an ASTM method (ASTM, 1975). A lognormal distribution was assumed, and the upper 5 percent significant level was used. Only two outliers were found, as follows:

- The mercury concentration $(0.065 \mathrm{mg} / \mathrm{kg})$ for Sample DT00002 from Location 1 was an outlier because all other reported concentrations were below the detection limit.

However, the mercury concentration of a laboratory duplicate of Sample DT00002 was below the detection limit of $0.051 \mathrm{mg} / \mathrm{kg}$.

- The sodium concentration $(1,110 \mathrm{mg} / \mathrm{kg}$ ) for Sample DT00024 from Location 6 was an outlier. The concentration was approximately twice that of the other soil samples. The reason for this high concentration is not known. Sodium is a component of salt, which typically occurs in a desert environment, such as at Double Tracks.

Concentrations of metals detected in subsurface soils are within the normal range of background and are not associated with the Double Tracks experiment.

\subsubsection{Toxicity Characteristic Leaching Procedure Results}

Three surface soil samples collected during the first characterization event were submitted for TCLP analysis of extractable metals. The samples were collected from the uppermost vertical profile interval ( 0 to $5 \mathrm{~cm}$ [0 to 2 in.]) at Locations 9,10 , and 11, near the ground zero area (Figure 3-1). As part of the second characterization event, surface soil samples from four hot spot locations were submitted for TCLP analysis of RCRA metals. The uppermost 2.5-cm (1-in.) soil interval from each location was collected for analysis. Concentrations of metals in the TCLP extracts are listed in Table 3-7, along with the toxicity characteristic regulatory levels. The 
Table 3-6

Metal Concentrations in Surface Soil at the Double Tracks Test Site

\begin{tabular}{|c|c|c|c|c|c|c|c|c|c|c|c|c|c|c|c|c|c|c|c|c|c|c|c|}
\hline Metal & Al & Sb & As & $8 a$ & $\overrightarrow{\mathrm{Be}}$ & cd & $\mathrm{Ca}$ & $\mathrm{Cr}$ & Co & $\mathrm{Cu}$ & $\mathrm{Fe}$ & $\mathrm{Pb}$ & $\mathrm{Mg}$ & $M n$ & $\mathrm{Hg}$ & $\mathbf{M i}$ & K & Se & $\mathrm{Ag}$ & $\mathrm{Na}$ & $T$ & $v$ & $\mathrm{Zn}$ \\
\hline $\begin{array}{l}\text { CAS } \\
\text { Number }\end{array}$ & $\begin{array}{c}7429 \cdot \\
90-5\end{array}$ & $\begin{array}{l}7440- \\
36-0\end{array}$ & $\begin{array}{l}7440- \\
38-2\end{array}$ & $\begin{array}{c}7440- \\
39-3\end{array}$ & $\begin{array}{c}7440- \\
41-7\end{array}$ & $\begin{array}{c}7440- \\
43-9\end{array}$ & $\begin{array}{c}7440- \\
70-2\end{array}$ & $\begin{array}{l}7440- \\
47-3\end{array}$ & $\begin{array}{c}7440 \\
48-4\end{array}$ & $\begin{array}{r}7440- \\
50-8\end{array}$ & $\begin{array}{c}7439- \\
89-6\end{array}$ & $\begin{array}{l}7439- \\
92-1\end{array}$ & $\begin{array}{l}7439- \\
95-4\end{array}$ & $\begin{array}{l}7439- \\
96-5\end{array}$ & $7439-97-6$ & $\begin{array}{l}7440- \\
02-0\end{array}$ & $\begin{array}{c}7440- \\
09-7\end{array}$ & $\begin{array}{c}7782- \\
49-2\end{array}$ & $\begin{array}{l}7440 \\
22-4\end{array}$ & $\begin{array}{c}7440- \\
23.5\end{array}$ & $\begin{array}{l}7440- \\
28-0\end{array}$ & $\begin{array}{l}7440- \\
62-2\end{array}$ & $\begin{array}{r}7440- \\
66-6\end{array}$ \\
\hline $\begin{array}{l}\text { Location } 1 \\
\text { DT00002 }\end{array}$ & 8,830 & $9.3 \mathrm{U}$ & 2.2 & 172 & $0.73 \mathrm{~B}$ & $0.75 \mathrm{U}$ & 11,600 & 4.1 & $4.5 \mathrm{~B}$ & 7.7 & 9,970 & 8.9 & 3,550 & 409 & $0.065 \mathrm{~B}$ & $5.7 \mathrm{~B}$ & 5,360 & $0.34 \mathrm{U}$ & $0.77 U$ & $523 \mathrm{~B}$ & $0.30 \mathrm{U}$ & 16.6 & 30.4 \\
\hline $\begin{array}{l}\text { Location } 1 \\
\text { DT00002 } \\
\text { Lab } \\
\text { Duplicate }\end{array}$ & 6,390 & $9.3 \mathrm{U}$ & 2.7 & 140 & $0.64 \mathrm{~B}$ & $0.75 \mathrm{U}$ & 11,700 & 3.3 & $4.1 \mathrm{~B}$ & 6.9 & 8,220 & 9.5 & 3,090 & 385 & $0.051 \cup$ & $4.8 \mathrm{~B}$ & 3,800 & $0.34 \mathrm{U}$ & $0.77 \mathrm{U}$ & $386 \mathrm{~B}$ & $0.30 \mathrm{U}$ & 12.4 & 25.5 \\
\hline $\begin{array}{l}\text { Location } 2 \\
\text { DT00006 }\end{array}$ & 9,050 & $9.3 \mathrm{U}$ & 2.1 & 182 & $0.73 \mathrm{~B}$ & $0.75 \mathrm{U}$ & 12,300 & 4.2 & $4.3 \mathrm{~B}$ & 6.2 & 11,000 & 11.8 & 3,520 & 447 & $0.051 \mathrm{U}$ & $5.6 \mathrm{~B}$ & 3,600 & $0.35 \mathrm{U}$ & $0.77 \mathrm{U}$ & $385 \mathrm{~B}$ & $0.30 \mathrm{U}$ & 19.2 & 33.5 \\
\hline $\begin{array}{l}\text { Location } 3 \\
\text { DT00010 }\end{array}$ & 9,460 & $9.3 \mathrm{U}$ & 3.1 & 151 & $0.73 \mathrm{~B}$ & $0.75 \mathrm{U}$ & 11,100 & 5.1 & $4.9 \mathrm{~B}$ & 7.3 & 12,200 & 10.7 & $\mathbf{3}, 880$ & 416 & $0.050 \mathrm{U}$ & $5.5 \mathrm{~B}$ & 4,090 & $0.34 \mathrm{U}$ & $0.77 \mathrm{U}$ & $446 \mathrm{~B}$ & $0.30 \mathrm{U}$ & 19.2 & 35.40 \\
\hline $\begin{array}{l}\text { Location } 4 \\
\text { DT00014 }\end{array}$ & 8,660 & $9.3 \mathrm{U}$ & 2.2 & 128 & $0.76 \mathrm{~B}$ & $0.75 \mathrm{U}$ & 19,800 & 5.0 & $5.3 \mathrm{~B}$ & 7.4 & 13,000 & 11.0 & 4,200 & 394 & $0.051 \mathrm{U}$ & $7.3 \mathrm{~B}$ & 3,960 & $0.34 \mathrm{U}$ & $0.77 \mathrm{U}$ & $476 \mathrm{~B}$ & $0.30 \mathrm{U}$ & 23.1 & 38.0 \\
\hline $\begin{array}{l}\text { Location } 4 \\
\text { Field Blank } \\
\text { DT00018 }\end{array}$ & $21.2 B$ & $9.2 \mathrm{U}$ & $0.36 \mathrm{U}$ & $0.56 \mathrm{~B}$ & $0.060 \mathrm{U}$ & $0.74 \mathrm{U}$ & $242 B$ & $1.1 \mathrm{U}$ & $0.68 \mathrm{U}$ & $1.5 \mathrm{U}$ & 36.6 & 0.72 & $39.2 \mathrm{~B}$ & $2.3 \mathrm{~B}$ & $0.050 \mathrm{U}$ & $3.1 \mathrm{U}$ & $389 \mathrm{U}$ & $0.34 \mathrm{U}$ & $0.76 \mathrm{U}$ & $70.5 \mathrm{~B}$ & $0.30 u$ & $1.9 U$ & $3.3 \mathrm{~B}$ \\
\hline $\begin{array}{l}\text { Location } 5 \\
\text { DT00019 }\end{array}$ & 7,090 & $9.3 \mathrm{U}$ & $1.7 \mathrm{~B}$ & 123 & $0.62 \mathrm{~B}$ & $0.75 \mathrm{U}$ & 12,000 & 4.4 & $4.2 \mathrm{~B}$ & 7.1 & 10,300 & 9.9 & 3,650 & 358 & $0.050 \mathrm{U}$ & $6.3 \mathrm{~B}$ & 3,290 & $0.34 \mathrm{U}$ & $0.77 \mathrm{U}$ & $524 \mathrm{~B}$ & $0.30 \mathrm{U}$ & 15.3 & 33.4 \\
\hline $\begin{array}{l}\text { Location } 6 \\
\text { DT00024 }\end{array}$ & 8,330 & $9.3 \mathrm{U}$ & 3.2 & 143 & $0.73 \mathrm{~B}$ & $0.75 \mathrm{U}$ & 16,900 & 5.2 & $5.4 \mathrm{~B}$ & 9.8 & 11,200 & 8.2 & 4,830 & 431 & $0.051 \mathrm{U}$ & $7.9 \mathrm{~B}$ & 4,790 & $0.34 \mathrm{U}$ & $0.77 \mathrm{U}$ & 1,110 & $0.30 \mathrm{U}$ & 17.70 & 41.3 \\
\hline $\begin{array}{l}\text { Location } 7 \\
\text { DT00028 }\end{array}$ & 9,360 & $9.3 \mathrm{U}$ & 3.2 & 159 & $0.76 \mathrm{~B}$ & $0.75 \mathrm{U}$ & 14,200 & 5.6 & $5.0 \mathrm{~B}$ & 8.4 & 12,100 & 10.3 & 4,720 & 453 & $0.051 \mathrm{U}$ & $8.0 \mathrm{~B}$ & 4.430. & $0.34 \mathrm{U}$ & $0.77 \mathrm{U}$ & $598 \mathrm{~B}$ & $0.30 \mathrm{U}$ & 18.7 & 35.9 \\
\hline $\begin{array}{l}\text { Location } 8 \\
\text { DTo0032 }\end{array}$ & 8,710 & $9.3 \mathrm{U}$ & 2.8 & 144 & $0.66 \mathrm{~B}$ & $0.75 \mathrm{U}$ & 15,600 & 4.7 & $3.7 \mathrm{~B}$ & 9.6 & 10,100 & 13.8 & 3,940 & 374 & $0.051 \mathrm{U}$ & $7.0 \mathrm{~B}$ & 4,040 & $0.34 \mathrm{U}$ & $0.77 \mathrm{U}$ & $479 \mathrm{~B}$ & $0.30 \mathrm{U}$ & 14.7 & 34.1 \\
\hline $\begin{array}{l}\text { Location } 12 \\
\text { DTO0049 }\end{array}$ & 10,300 & $9.3 U$ & 3.0 & 167 & $0.76 \mathrm{~B}$ & $0.75 \mathrm{U}$ & 13,300 & 6.3 & $5.2 \mathrm{~B}$ & 9.0 & 13,500 & 10.1 & 4,760 & 487 & $0.051 \mathrm{U}$ & $7.5 \mathrm{~B}$ & 4,130 & $0.34 U$ & $0.77 \mathrm{U}$ & 5238 & $0.30 \mathrm{U}$ & 20.8 & 38.6 \\
\hline
\end{tabular}

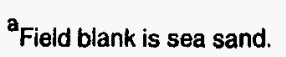

Notes:

All concentrations are in milligrams per kilogram $(\mathrm{mg} / \mathrm{kg})$ or parts per million (ppm).

Surface soil samples collected from depth interval of 0 to 5 centimeters ( 0 to 2 inches)

See Figure 3-1 for soil sample locations.

Data Qualifiers:

$B=$ Reported value is less than the contract-required detection limit but greater than or equal to the instrument detection limit.

$\mathrm{U}=$ Compound was analyzed for but not detected. The value listed is the instrument detection limit. 
Table 3-7

Toxicity Characteristic Leaching Procedure Results for Surface Soil Samples from the Double Tracks Test Site

\begin{tabular}{|c|c|c|c|c|c|c|c|c|c|}
\hline$\overbrace{\text { Metal }}$ & $\underset{\text { Number }}{\text { CAS }}$ & $\begin{array}{l}\text { Location } 9 \\
\text { Soil Sample } \\
\text { DT00036 } \\
\text { (mg/L) }\end{array}$ & $\begin{array}{c}\text { Location } 10 \\
\text { Soil Sample } \\
\text { DT00040 } \\
(\mathrm{mg} / \mathrm{L})\end{array}$ & $\begin{array}{c}\text { Location } 11 \\
\text { Soll Sample } \\
\text { DT00045 } \\
\text { (mg/L) }\end{array}$ & $\begin{array}{c}\text { Hot Spot } 1 \\
\text { Soll Sample } \\
\text { DT00100 } \\
(\mathrm{mg} / \mathrm{L})\end{array}$ & $\begin{array}{l}\text { Hot Spot } 3 \\
\text { Soll Sample } \\
\text { DT00102 } \\
(\mathrm{mg} / \mathrm{L})\end{array}$ & $\begin{array}{l}\text { Hot Spot } 4 \\
\text { Soll Sample } \\
\text { Dro0103 } \\
\text { (mg/L) }\end{array}$ & $\begin{array}{c}\text { Hot Spot } 5 \\
\text { Soil Sample } \\
\text { DT00104 } \\
\text { (mg/L) }\end{array}$ & $\begin{array}{c}\text { Regulatory } \\
\text { Level } \\
\text { (mg/L) }\end{array}$ \\
\hline Arsenic & $7440-38-2$ & 0.011 & 0.004 & 0.014 & 0.0078 & 0.0074 & 0.0092 & 0.0061 & 5.0 \\
\hline Barium & $7440-39-3$ & 0.45 & $0.200 \mathrm{U}$ & 0.42 & 0.40 & 0.43 & 0.39 & 0.44 & 100.0 \\
\hline Cadmium & $7440-43-9$ & $0.005 \mathrm{U}$ & $0.005 \mathrm{U}$ & $0.005 \mathrm{U}$ & $0.0024 \mathrm{U}$ & $0.0024 \mathrm{U}$ & $0.0024 \mathrm{U}$ & $0.0024 \mathrm{U}$ & 1.0 \\
\hline Chromium & $7440-47-3$ & $0.020 \mathrm{U}$ & $0.020 \mathrm{U}$ & $0.020 \mathrm{U}$ & $0.0047 \mathrm{U}$ & $0.0047 \mathrm{U}$ & $0.0047 \mathrm{U}$ & $0.0047 \mathrm{U}$ & 5.0 \\
\hline Lead & $7439-92-1$ & 0.008 & $0.003 \mathrm{U}$ & $0.003 \mathrm{U}$ & 0.0077 & 0.0050 & $0.0020 \mathrm{~B}$ & $0.0022 \mathrm{~B}$ & 5.0 \\
\hline Mercury & $7439-97-6$ & $0.002 U$ & $0.002 \mathrm{U}$ & $0.002 \mathrm{U}$ & $0.00010 \mathrm{U}$ & 0.00029 & $0.00012 B$ & $0.00016 \mathrm{~B}$ & 0.2 \\
\hline Selenium & $7782-49-2$ & 0.007 & 0.004 & 0.006 & 0.0096 & 0.0096 & 0.0091 & 0.0096 & 1.0 \\
\hline Silver & $7440-22-4$ & $0.010 \mathrm{U}$ & $0.010 \mathrm{U}$ & $0.01 U$ & $0.0041 \mathrm{U}$ & $0.0041 \mathrm{U}$ & $0.0041 \mathrm{U}$ & $0.0041 U$ & 5.0 \\
\hline
\end{tabular}

${ }^{a}$ Chemical Abstracts Service Number

Notes:

See Figure 3-1 for soll sample locations.

All concentrations are in milligrams per liter.

Data Quallifiers:

$B=$ Reported value is less than the contract-required detection limit but greater than or equal to the instrument detection limit.

$U=$ Compound was analyzed for but not detected. The stated activity is the instrument detection limit. 
extract was analyzed using EPA SW-846 Method 6010 and Method 7470 for mercury (EPA, 1990b).

The samples selected for TCLP analysis were collected from areas suspected of being impacted by the Double Tracks test event. As discussed in Section 3.1.1, the highest activities of plutonium identified during the first characterization event were found at Location 10 and relatively high levels were also observed at Location 9. During the second characterization event, hot spot soil samples were collected from areas of plutonium contamination (Section 3.1.1). Table 3-7 shows that concentrations of RCRA metals in TCLP extracts are orders of magnitude lower than the regulatory levels. This, combined with the knowledge that the soil samples were collected from areas impacted by the Double Tracks experiment, strongly indicates that Double Tracks soil does not exhibit toxicity characteristics as defined in Title 40 CFR 261.24 (EPA, 1994); therefore, the soil from the Double Tracks Test Site cannot be classified as mixed waste based on the toxicity characteristics.

\subsection{Horizontal Extent of Contamination}

Previous characterization activities have shown that data from the collection and analysis of soil samples cannot effectively be used to delineate the horizontal extent of contamination at the Double Tracks Test Site (Sections 1.4 and 3.1.1). This is because contamination levels are highly variable on the spatial scale represented by discrete soil samples. Thus, to evaluate the horizontal extent of contamination, in situ radiological surveys were conducted. In situ techniques allowed more coverage of the potentially contaminated area and provided data that are "averaged" over the field of view of the detector. These features of in situ techniques provide for better estimates of contaminated soil volume relative to those made using discrete soil sample data.

During the second characterization event, the performance of various in situ survey equipment and methods was evaluated (Section 2.2). Systematic in situ radiological surveys were performed during the third characterization event (Section 2.3). In general, the in situ surveys measured gamma radiation from Am-241, and information obtained from the analysis of discrete soil samples was used to convert the in situ Am-241 measurements into the total TRU isotope activity of the soil. The details of the in situ radiological survey work are presented in In Situ Radiological Surveying at the Double Tracks Test Site (Riedhauser and Tipton, 1996), which is included as Appendix D of this report. Although several different in situ radiological surveys were performed, only the results of the systematic survey conducted using the Suburban-mounted $\mathrm{NaI}$ detector (Kiwi system; Section 2.3.1.2) are discussed here. Appendix D provides 
information on the other surveys and in situ measurements performed to characterize the Double Tracks test site.

Figure 3-5 shows the total TRU isotope activity of soil at the Double Tracks Test Site, as derived from in situ measurements obtained using the Kiwi system. The radioactivity measurements were collected into 9.1-m (30-ft) averages and centered on a $9.1-\mathrm{m}(30-\mathrm{ft})$ grid. Comparing this survey to 1977 and 1993 aerial surveys (Figures 1-3 and 1-4) shows that the extent of contamination in the east-west direction (across the plume) is less than indicated by the older aerial surveys. This is anticipated because the Kiwi spatial resolution is much smaller than that of the aerial systems. The highest levels of plutonium and americium are located in and around ground zero, and a relatively narrow plume of total TRU activity exceeding $100 \mathrm{pCi} / \mathrm{g}$ extends to the south of ground zero, almost to the southern end of the exclusion zone (Figure 3-5). Small areas of high activity in the vicinity of ground zero may represent hot spots that were not removed. The small area of elevated activity at the edge of the exclusion zone, southeast of ground zero, is the container holding the radioactive fragments discussed in Section 3.1.3.

\subsection{Vertical Extent of Contamination}

Along with the surface soil samples discussed in Section 3.1.1, vertical profile soil samples were collected from the 12 locations shown in Figure 3-1. In addition to the 0 - to 5-cm (0- to 2-in.) interval, discrete soil samples were also collected from the 5- to 10-cm (2- to 4-in.) and 10- to 15-cm (4- to 6-in.) depth intervals. These samples were analyzed for Am-241, isotopic plutonium, and isotopic uranium by the methods listed in Section 3.1.1. Results from the first characterization event indicated that plutonium and americium concentrations generally were not consistent with what was anticipated. This was the case with both the horizontal and vertical soil sampling results. Only one sampling location $(\mathrm{E}-10)$ detected significant radiological contamination above $200 \mathrm{pCi} / \mathrm{g}$. The other nine depth profile locations depth profile results were inconclusive, especially when contaminants were detected at or near the laboratory detection limit. The depth profile results are presented in Appendix $\mathrm{E}$ for completeness.

Realizing that laboratory soil results were inconsistent, part of the second characterization event included the vertical distribution of contamination in situ measurements at selected hot spot locations. The rationale for this approach was to determine depth of contamination in areas where significant contamination were known to be present. A tripod-mounted collimated HPGe detector or a hand-held FIDLER was used to measure the radioactivity of the undisturbed sample location. After the measurement was taken, a $2.5-\mathrm{cm}$ (1-in.) layer of soil was removed and the 



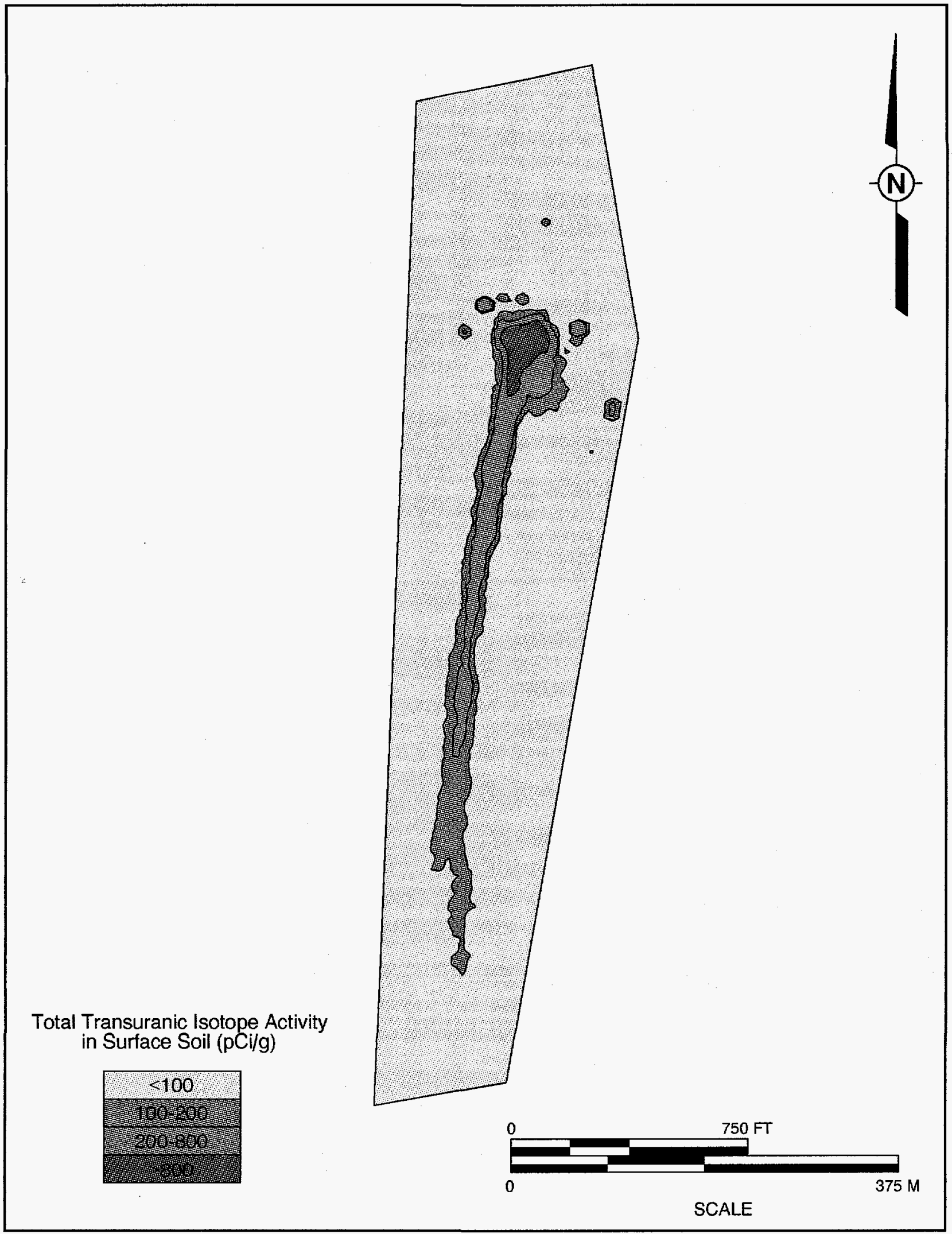

Figure 3-6

Total Transuranic Isotope Activity of Double Tracks Soil, Based on 1995 EG\&G Ground Survey

\section{3-22}



activity of the sample location was again measured. This process was repeated until approximately 80 to 90 percent of the initial radioactivity had been removed (Section 2.2.3).

Table 3-8 presents the results of the in situ radiological depth profiles. These results indicated that 80 to 90 percent of the radioactivity was generally in the top $5 \mathrm{~cm}$ ( 2 in.) of the soil at the locations measured. During the second characterization event, the vertical distribution of contamination was also investigated using adhesive-backed tiles to remove thin layers of soil (less than $1 \mathrm{~cm}$ ) from a hot spot sample location. An in situ radiological survey of the location was conducted before and after soil removal, and the results were compared. The results indicate that most of the radioactivity is contained within the uppermost 0.3 to $1.3 \mathrm{~cm}(0.1$ to 0.5 in.) of the soil profile; however, the data from this technique are considered semiquantitative.

\subsection{Ground Zero Characterization}

As part of the third characterization event, 17 shallow boreholes were drilled in the ground zero area, and in situ radiation measurements were taken using a downhole $\mathrm{NaI}$ detector (Section 2.3.3). Figure 3-6 shows the approximate location of each boring, and Table 3-9 lists the radioactivity measured at each boring. The depth of the ground zero borings ranged from 0.5 to $1.4 \mathrm{~m}$ ( 1.6 to $4.5 \mathrm{ft}$ ). Several of the borings intercepted the suspected concrete pad on which the Double Tracks test was conducted (Figure 3-6). The suspected concrete pad is covered by a soil mound that is approximately 0.5 to $0.9 \mathrm{~m}$ (1.6 to $3.0 \mathrm{ft})$ high. Levels of activity greater than $1 \times 10^{4}$ counts per minute were found at depth in the borings (Table 3-9), confirming that contaminated soil and possibly metallic material from the test are present in the ground zero mound.

\subsection{Soil Particle-Size and Volume Reduction Testing}

Several observations were made that require discussion before the grain-size and analytical results can be presented. The first observation is that the measured plutonium activity of the samples did not generally and uniformly decrease with distance from ground zero, as shown on Figure 3-7. It is not known whether this was caused by variability of the experiment fallout, varied distribution of the contaminants in the soil, or the presence of hot particles at the sample locations. The second observation is that the plutonium content of the coarse soil fraction determined by gamma spectroscopy analysis in the ITPDL and by isotopic analysis in the radiological laboratory were not always similar. It is anticipated that, while the analytical methods are different, the results should be comparable because the same soil sample was being analyzed. These analyses do not agree for 3 of the 10 sample locations, which may indicate that 
Table 3-8

In Situ Radiological Measurements of Depth Profiles at the Double Tracks Test Site

\begin{tabular}{|c|c|c|c|c|c|c|c|}
\hline \multirow{2}{*}{ Location } & \multirow{2}{*}{$\begin{array}{c}\text { Surtace } \\
\text { Measurement }\end{array}$} & \multicolumn{2}{|c|}{$\begin{array}{l}\text { Measurement after Removal of } \\
\text { Uppermost } 2.5 \mathrm{~cm} \text { of Soil }\end{array}$} & \multicolumn{2}{|c|}{$\begin{array}{l}\text { Measurement after Removal of } \\
\text { Uppermost } 5.1 \mathrm{~cm} \text { of Soil }\end{array}$} & \multirow{2}{*}{$\begin{array}{l}\text { Measurement } \\
\text { Units }\end{array}$} & \multirow{2}{*}{$\begin{array}{c}\text { In Situ } \\
\text { Measurement } \\
\text { Device }\end{array}$} \\
\hline & & Measurement & $\begin{array}{l}\text { Percent Activity } \\
\text { Removed }\end{array}$ & Measurement & $\begin{array}{l}\text { Percent Activity } \\
\text { Removed }\end{array}$ & & \\
\hline \multirow{2}{*}{ Hot Spot 2} & \multirow{2}{*}{60,000} & 9,000 & 85 & \multirow{2}{*}{8,000} & \multirow{2}{*}{87} & \multirow{2}{*}{$\begin{array}{l}\text { counts per } \\
\text { minute }\end{array}$} & \multirow{2}{*}{ FIDLER } \\
\hline & & 14,000 & 77 & & & & \\
\hline \multirow[b]{2}{*}{ Hot Spot 4} & 5,820 & 4,510 & 23 & 4,232 & 27 & $\begin{array}{c}\text { total counts, } \\
10 \text { minute count } \\
\text { time }\end{array}$ & HPGe Detector \\
\hline & 1,123 & 47 & 96 & 0 & 100 & $\begin{array}{l}\text { net americium- } \\
241 \text { counts, } \\
10 \text { minute count } \\
\text { time }\end{array}$ & HPGe Detector \\
\hline Hot Spot 5 & 30,000 & 5,400 & 82 & 5,000 & 83 & $\begin{array}{l}\text { counts per } \\
\text { minute }\end{array}$ & FIDLER \\
\hline Hot Spot 6 & 90,000 & 8,000 & 91 & 7,400 & 92 & $\begin{array}{l}\text { counts per } \\
\text { minute }\end{array}$ & FIDLER \\
\hline
\end{tabular}

\section{Notes:}

Measurement locations are shown in Figure 3-2.

Measurement made at undisturbed hot spot location, after removal of any large metallic fragments

At Hot Spot 2, duplicate values indicated count rates were measured in samples split with a Jones type soil splitter.

At Hot Spot 4, two measurements were made of the same soil. The first was total counts and the second was net americium-241 counts.

FIDLER = Field instrument for the Detection of Low Energy Radiation. Measurements were made until a consistent count rate was obtained, typically this was less than one minute.

$\mathrm{HPGE}=$ High purity germanium $(\mathrm{Ge})$ 


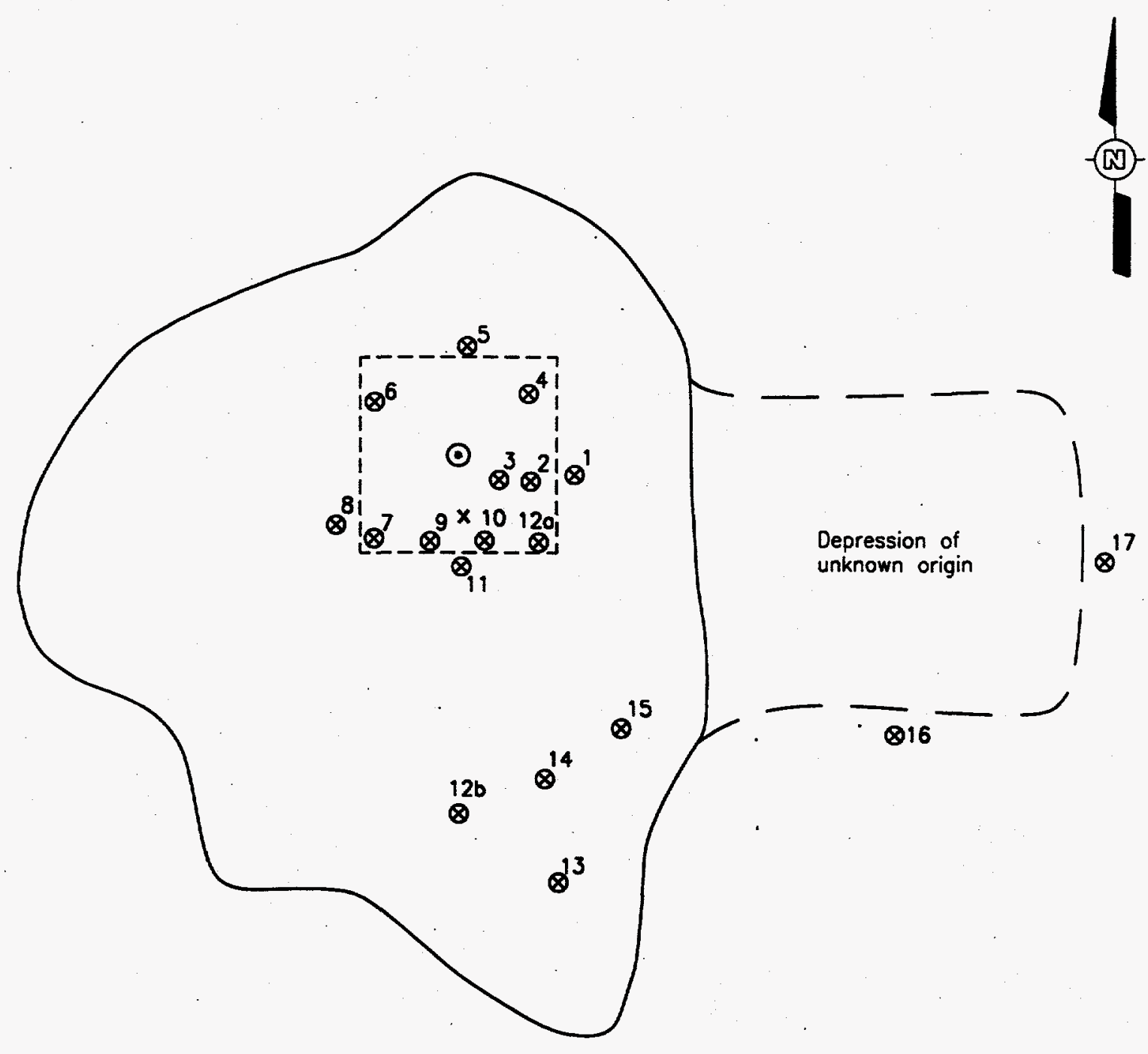

SCALE

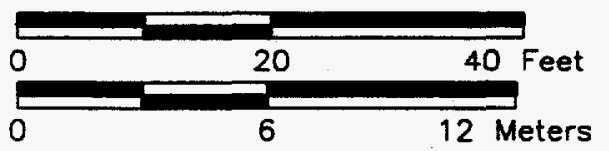

LEGEND

Approximate edge of ground zero mound

Note: 1. Historical records indicate buried concrete slab is 6.1 meters ( 20 feet) square.

2. Edge of ground zero bosed on change in surface slope.

3. Field records indicote two borings labeled 12. Boring 12 numbers have been modified to $12 a$ and $12 b$.

Figure 3-7

Location of Soil Borings in Ground Zero Area of the Double Tracks Test Site 



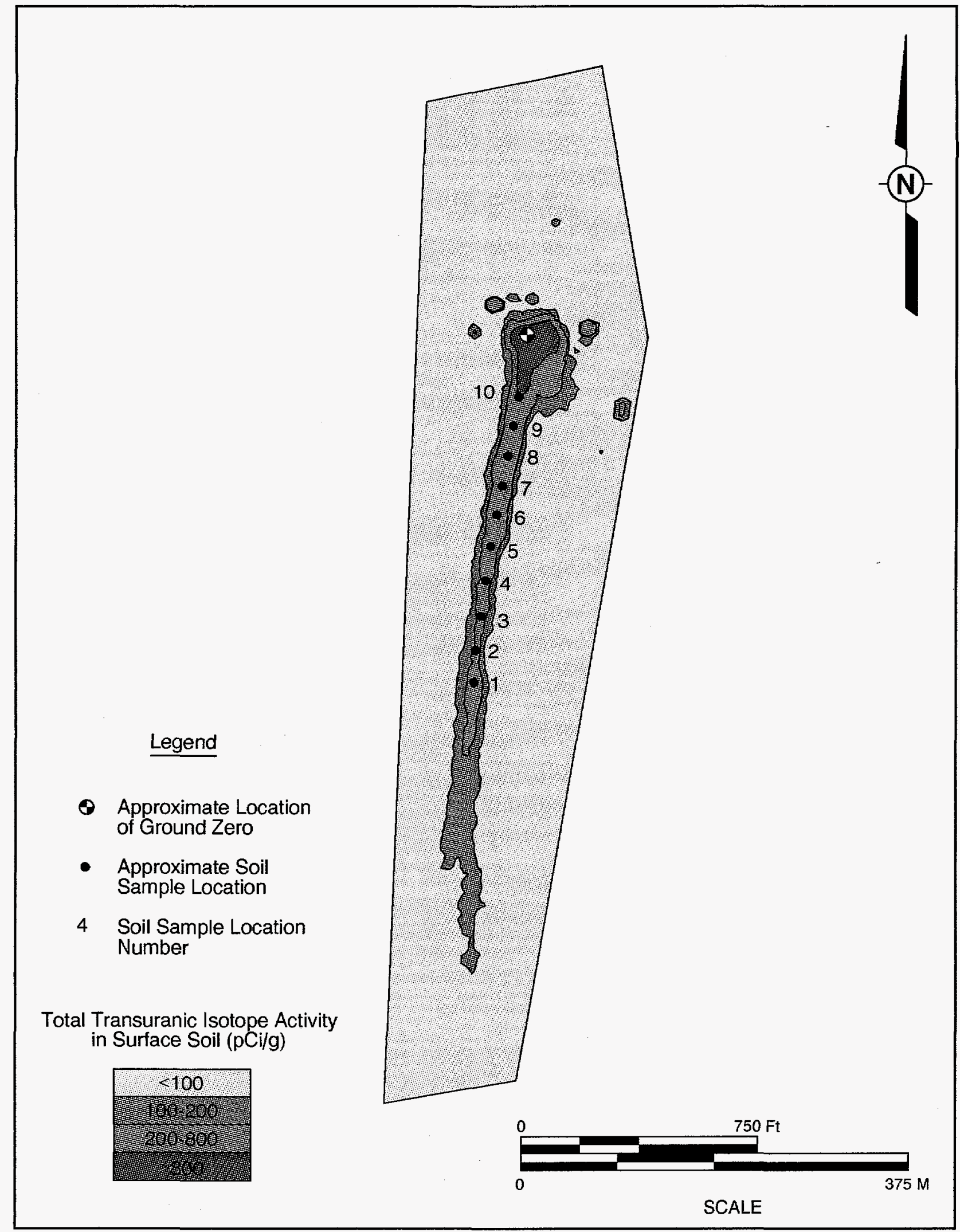

Figure 3-8

Location of Soil Samples Collected During the Fourth Characterization Event 

Table 3-9

In Situ Radiological Measurements in Ground Zero Soil Borings

\begin{tabular}{|c|c|c|c|c|c|c|c|c|c|c|c|c|c|c|}
\hline $\begin{array}{c}\text { Depth Below } \\
\text { Ground Surface } \\
\text { (meters) }\end{array}$ & $\begin{array}{c}\text { Boring } 1^{\mathrm{a}} \\
(1,000 \text { count } \\
\text { per minute })\end{array}$ & \begin{tabular}{|c|} 
Boring 2 \\
$(1,000$ count \\
per minute $)$
\end{tabular} & \begin{tabular}{|l} 
Boring 4 \\
$(1,000$ count \\
per minute)
\end{tabular} & \begin{tabular}{|c|} 
Boring 5 \\
(1,000 count \\
per minute)
\end{tabular} & $\begin{array}{l}\text { Boring } 7 \\
(1,000 \text { count } \\
\text { per minute })\end{array}$ & $\begin{array}{l}\text { Boring 8 } \\
\text { (1,000 count } \\
\text { per minute) }\end{array}$ & \begin{tabular}{|c|} 
Boring 9 \\
$(1,000$ count \\
per minute $)$
\end{tabular} & $\begin{array}{l}\text { Boring 10 } \\
\text { (1,000 count } \\
\text { per minute) }\end{array}$ & $\begin{array}{l}\text { Boring } 11 \\
(1,000 \text { count } \\
\text { per minute) }\end{array}$ & $\begin{array}{l}\text { Boring 12a } \\
(1,000 \text { count } \\
\text { per minute) }\end{array}$ & $\begin{array}{l}\text { Boring } 14 \\
(1,000 \text { count } \\
\text { per minute })\end{array}$ & \begin{tabular}{|l|} 
Boring 15 \\
$(1,000$ count \\
per minute $)$
\end{tabular} & \begin{tabular}{|l|} 
Boring 16 \\
(1,000 count \\
per minute $)$
\end{tabular} & $\begin{array}{c}\text { Borlng } 17 \\
(1,000 \text { count } \\
\text { per minute) }\end{array}$ \\
\hline 0.0 (surtace) & 9 & 8 & 5.6 & 5 & 6 & 5 & 6.1 & 6.5 & 8.5 & 14 & 20 & 50 & 35 & 180 \\
\hline$\cdot \quad 0.15$ & 20 & 16 & 6.3 & 6 & 6 & 5.6 & 12 & 15 & 13 & 7.7 & 100 & 25 & 10 & 6 \\
\hline 0.30 & 25 & 22 & 8.7 & 7 & 6.5 & 7 & 10 & 17 & 13 & 12 & 200 & 8 & 8 & 5.5 \\
\hline 0.46 & 40 & 14 & 16 & 7 & 17 & 14 & 10 & 19 & 12 & 11 & 90 & 7.5 & 6 & 10 \\
\hline 0.61 & 52 & $14^{b . c}$ & 11 & 6.6 & 17 & 7 & $8.4^{b}$ & 25 & 10 & 9.5 & 38 & 6.7 & 9 & $12^{d}$ \\
\hline 0.76 & 80 & & $16^{b, \theta}$ & 6 & 10 & 6 & & $16^{b}$ & 10 & 13 & 37 & 5.3 & $16^{f}$ & \\
\hline 0.91 & 200 & & & 6.2 & $28^{b}$ & 5.5 & . & & 9 & $8^{b}$ & $50^{9}$ & 5.4 & . & \\
\hline 1.07 & 620 & & & $5: 5^{h}$ & & 6 & & & $14^{h}$ & & & 5.7 & & \\
\hline 1.22 & 600 & & & & & 6 & & & & & & 7.3 & & \\
\hline 1.37 & 600 & & & & & & & & & & & $16^{1}$ & & \\
\hline
\end{tabular}

${ }^{a}$ See Figure 3-7 for boring locations.

Boring refusal, concrete slab

Bottom of boring is at 0.48 meters below ground surface.

Bottom of boring is at 0.51 meters below ground surface.

Bottom of boring is at 0.66 meters below ground surface.

Battom of boring is at 0.69 meters below ground surface.

Bottom of boring is at 0.84 meters below ground surface.

hottom of boring is at 1.02 meters below ground surface.

'Bottom of boring is at 1.32 meters below ground surface.

Note: Radiological measurements not collected in borings $3,6,12 \mathrm{~b}$, and 13

Average background ranged between 200 to 400 counts per minule $(0.2$ to $0.41,000$ counts per minute) 
hot particles are present. This heterogeniety within soil analysis has been reported by previous investigators.

Results of the grain-size analysis were that the attrition scrubbing effectively removed the fine material from the coarse material. Grain-size analysis results are summarized on Table 3-10 and the data presented in Appendix F. Average grain-size analysis indicated that 84 percent of the soil was coarser than 100 mesh, larger than fine sand before attrition scrubbing. Attrition scrubbing removed on the average an additional 19 percent more fine-grained material from the coarse-grained material.

Gamma spectroscopy analysis and laboratory isotopic analyses indicated that generally, the contaminants did concentrate in the fine fraction before and after attrition scrubbing (Table 3-11). Based on gamma spectroscopy analysis before attrition scrubbing, 4 of the coarse fractions had activities below $100 \mathrm{pCi} / \mathrm{g}$ total transuranics, and seven had activities below $200 \mathrm{pCi} / \mathrm{g}$. Based on gamma spectroscopy analysis after attrition scrubbing, all but Sample 7 (256 pCi/g total transuranics) had activities less than $200 \mathrm{pCi} / \mathrm{g}$. Sample 7 had an activity of $18.5 \mathrm{pCi} / \mathrm{g}$ plutonium $239 / 240$ in the fine fraction based on more precise isotopic analysis. Note that Sample 5 had an increase after attrition scrubbing of $107 \mathrm{pCi} / \mathrm{g}$.

Isotopic analysis after attrition scrubbing indicated that for most of the samples the contaminants were generally concentrated in the fine fraction (Table 3-11). Exceptions to this are the coarse fractions of Samples 3 and 5, which had unanticipated high activities. Sample 5 had 1,040 pCi/g plutonium $239 / 240$ in the coarse fraction and $1,880 \mathrm{pCi} / \mathrm{g}$ in the fine fraction. Sample $3 \mathrm{had}$ $413 \mathrm{pCi} / \mathrm{g}$ plutonium $239 / 240$ in the coarse fraction and $304 \mathrm{pCi} / \mathrm{g}$ in the fine fraction. The Sample 5 and 3 results indicate that some contaminants larger in size than fine sand are present, since high activities were detected in the coarse fraction. Sample three was reanalyzed with no significant activity changes. This demonstrates that larger than anticipated contaminated material was present in two of the soil samples.

The results of the treatability testing are that, for eight of the ten soil samples tested, the use of volume reduction will work at Double Tracks Test Site. This represents 80 percent of the samples tested. Technically, it is inconclusive if volume reduction via grain size separation will work at the Double Tracks Test Site. Because of the relative small volume of soil requiring corrective action, volume reduction is probably not economically feasible. Analysis of volume reduction options will continue during remediation of the Double Tracks Test Site and characterization of the Clean Slate Test Sites. It is anticipated that volume reduction may be 
Table 3-10

Grain-Size Analysis of Treatability Study Samples

\begin{tabular}{||c|c|c|c|c|c|c||}
\hline \multirow{2}{*}{$\begin{array}{c}\text { Sample } \\
\text { Location }\end{array}$} & \multicolumn{2}{c|}{$\begin{array}{c}\text { ITPDL' } \\
\text { Before Attrition } \\
\text { Scrubbing }\end{array}$} & \multicolumn{2}{c|}{$\begin{array}{c}\text { DRI } \\
\text { No Attrition Scrubbing }\end{array}$} & \multicolumn{2}{c||}{$\begin{array}{c}\text { ITPDL } \\
\text { After Attrition Scrubbing }\end{array}$} \\
\cline { 2 - 8 } & $\begin{array}{c}\text { Fine } \\
\text { Fraction }\end{array}$ & $\begin{array}{c}\text { Coarse } \\
\text { Fraction }\end{array}$ & $\begin{array}{c}\text { Fine } \\
\text { Fraction }\end{array}$ & $\begin{array}{c}\text { Coarse } \\
\text { Fraction }\end{array}$ & $\begin{array}{c}\text { Fine } \\
\text { Fractionc }\end{array}$ & $\begin{array}{c}\text { Coarse } \\
\text { Fraction }\end{array}$ \\
\hline 1 & 22 & 78 & 25 & 75 & 35 & 65 \\
\hline 2 & 17 & 83 & 21 & 79 & 30 & 70 \\
\hline 3 & 8 & 92 & 19 & 81 & 23 & 77 \\
\hline 4 & 12 & 88 & 30 & 70 & 38 & 62 \\
\hline 5 & 22 & 78 & 36 & 64 & 43 & 57 \\
\hline 6 & 23 & 77 & 27 & 73 & 38 & 62 \\
\hline 7 & 25 & 75 & 23 & 77 & 39 & 61 \\
\hline 8 & 9 & 91 & 14 & 86 & 24 & 76 \\
\hline 9 & 24 & 76 & 31 & 69 & 41 & 59 \\
\hline 10 & 2 & 98 & 29 & 71 & 39 & 61 \\
\hline Average & 16 & 84 & 26 & 74 & 35 & 65 \\
\hline
\end{tabular}

IT Corporation Process Development Laboratory located in Knoxville, TN

Desert Research institute Laboratory located at the Nevada Test Site

CFine fraction is smaller than \#100 Mesh, 149 microns.

Fine fraction is smaller than \#125 Mesh, 125 microns.

Notes:

All values are in weight percent.

See Figure 3-8 for soil sample location. 
Table 3-11

Summary of Gamma Spectroscopy and Isotopic Analysis of Treatability Study Samples

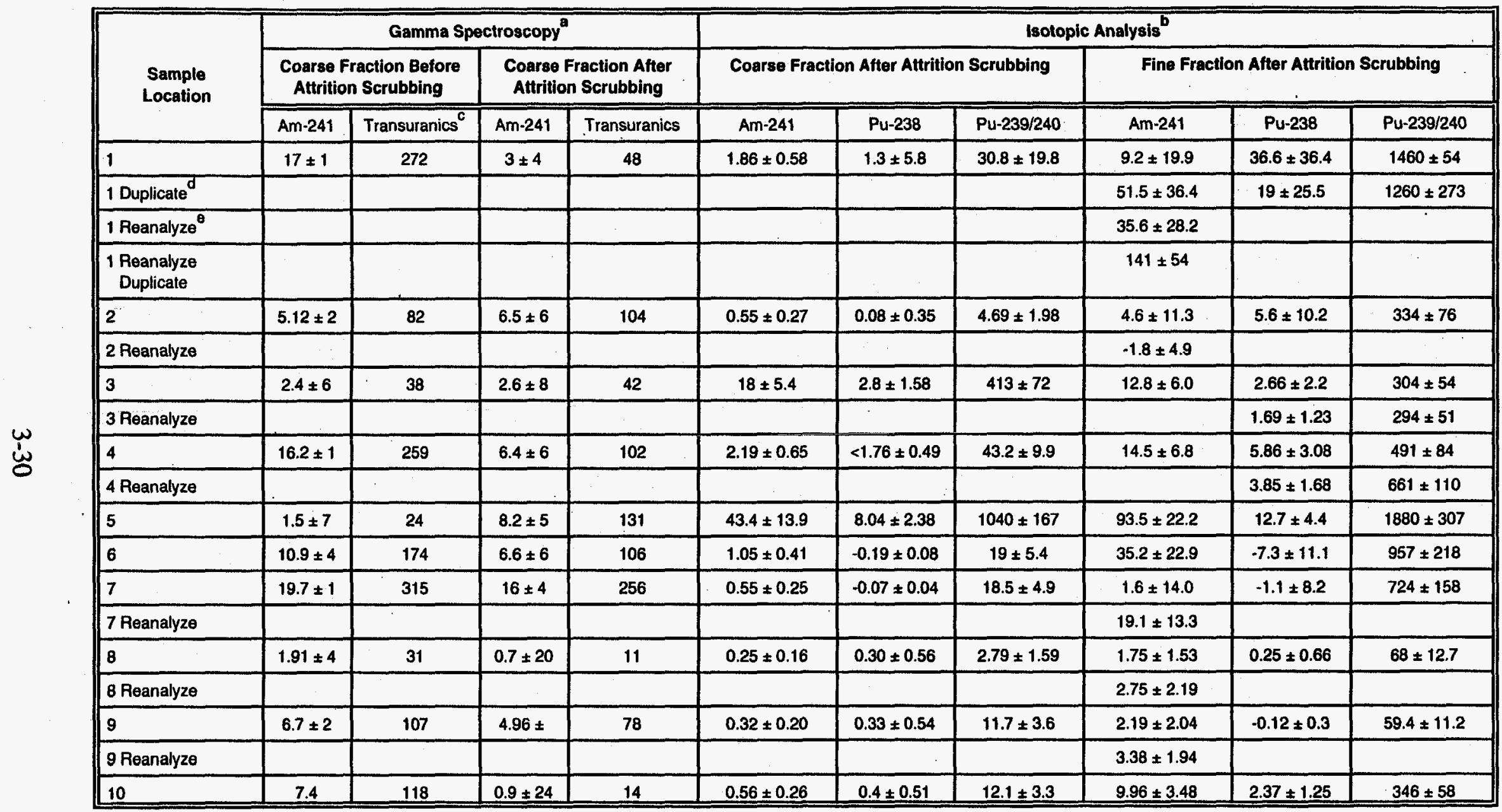

a Gamma spectroscopy performed at the IT Process Development Laboratory (Knoxville, TN)

Isotopic analysis performed at the radiologic laboratory (St. Louis, MO)

Total Transuranic Isotopes, assuming a total tranuranics to Am-241 ratio of 16

Duplicate analyses were for quality control.

${ }^{\ominus}$ Selected samples were reanalyzed because of relatively large two-sigma errors.

Note:

Negative values $(-)$ are values less than the minimum detection activity (MDA)

All values reported in $\mathrm{pCi} / \mathrm{g}$

See Figure 3-8 for sample locations. 
implemented during the remediation of the Double Tracks Test Site, if different physical conditions are encountered than are currently anticipated. After Clean Slate I Test Site characterization, more site characterization treatability testing and data will be examined to determine if volume reduction can be implemented.

\subsection{Contaminated Soil Volume}

Table 3-12 presents an estimate of the surface area and volume of contaminated soil at the Double Tracks Test Site exceeding $200 \mathrm{pCi} / \mathrm{g}$ plutonium $239 / 240$ of total activity. The surface area estimates are based on the results of the EG\&G Kiwi system radiological survey conducted during the third characterization event (Section 3.3 and Appendix D). To provide more flexibility in the estimates of the soil volume to be remediated, the area of contamination was divided into the ground zero mound and north area and south areas (Table 3-12). The ground zero mound was defined as the topographically elevated area at ground zero investigated during the third characterization event (Section 3.5). The north area was defined as the area of contaminated soil immediately around the ground zero area, and the south area was defined as the long, narrow strip of contamination extending south of ground zero (Figure 3-6). An estimated $219 \mathrm{~m}^{3}\left(286 \mathrm{yd}^{3}\right)$ of contaminated soil is present in the mound at ground zero (Table 3-12). The average height of the mound is $0.5 \mathrm{~m}(1.7 \mathrm{ft})$. This assumption is based on information obtained from the ground zero soil borings discussed in Section 3.5. The other soil volumes calculated for the ground zero mound area assume that, in addition to the mound itself, a uniform thickness of soil will be removed. Estimates are given for uniform soil thicknesses ranging from 15 to $46 \mathrm{~cm}$ ( 6 to $18 \mathrm{in}$.).

Based on in situ ground-based radiation survey data, the total surface area at Double Tracks containing activity greater than $200 \mathrm{pCi} / \mathrm{g}$ plutonium $239 / 240$ is approximately 8,780 square meters $(94,500$ square feet), approximately 1 hectare. For estimating the volume of soil requiring remediation, it was assumed a 30-cm (12-in.) layer of soil beneath the mound, a 15-cm (6-in.) layer of soil in the north area, and an 8-cm (3-in.) layer of soil in the south area will require remediation. The estimated total soil volume to be remediated is approximately $1,240 \mathrm{~m}^{3}$ $\left(1,620 \mathrm{yd}^{3}\right)$. Approximately 28 percent of this soil is from the ground zero mound area, 39 percent is from the north area, and 33 percent is from the south area. The soil volume estimates do not take into account soil expansion that occurs during excavation. Soil of the type found at the Double Tracks Test Site typically will expand 20 to 25 percent during dry excavation. However, the soil will be wetted during site remediation as part of the dust suppression activities. This may significantly reduce the soil expansion percent, possibly to less than 10 percent. 
Table 3-12

Estimates of Area and Volume of Soil Exceeding 200 Picocuries per Gram of Total Transuranic Isotope Activity at the Double Tracks Test Site

\begin{tabular}{|c|c|c|c|c|c|c|}
\hline \multirow{2}{*}{ Location } & \multicolumn{2}{|c|}{ Depth } & \multicolumn{2}{|c|}{ Surface Area $^{a}$} & \multicolumn{2}{|c|}{ Soil Volume } \\
\hline & centimeters & inches & $\begin{array}{l}\text { square } \\
\text { meters }\end{array}$ & square feet & cubic meters & cubic yards \\
\hline \multirow{5}{*}{$\begin{array}{l}\text { Ground } \\
\text { Zero } \\
\text { Mound }\end{array}$} & \multicolumn{2}{|c|}{ Soil in Mound } & 420 & 4,500 & 219 & 286 \\
\hline & 15 & 6 & & & 282 & 369 \\
\hline & 23 & 9 & & & 314 & 411 \\
\hline & 30 & $\sqrt{12}$ & & 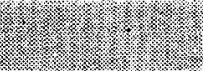 & 346 & 453 \\
\hline & 46 & 18 & & & 412 & 536 \\
\hline \multirow{4}{*}{ North Area } & 8 & 3 & 3,260 & 35,100 & 261 & 341 \\
\hline & 15 & 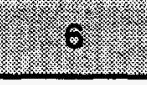 & & & 489 & 640 \\
\hline & 23 & 9 & & & 750 & 981 \\
\hline & 30 & 12 & & & 978 & 1,279 \\
\hline \multirow{4}{*}{ South Area } & 2.8 & 3 & $=5.100$ & 54,900 & 408 & $=584$ \\
\hline & 15 & 6 & & & 765 & 1,001 \\
\hline & 23 & 9 & & & 1,173 & 1,534 \\
\hline & 30 & 12 & & & 1,530 & 2,001 \\
\hline
\end{tabular}

${ }^{\text {a }}$ Surface area is based on 1995 ground survey radiation measurements (Figure 3-6).

Shaded volumes were the values used to calculate the volume of soil requiring disposal at the Double Tracks Test Site $(346+489+408=1,243$ cubic meters $)$. 


\subsection{Summary and Conclusions}

The summary and conclusions derived from the site characterization efforts at the Double Tracks Test Site are described in this section.

\subsection{Summary}

Previous investigations of the Double Tracks Test Site provided considerable information on the nature and extent of contamination. Aerial radiological surveys provided an estimate of the extent of the radiological contamination at the site, and discrete soil sample results indicated that plutonium and americium were present in surface soil. Data gaps identified before this site characterization started included the possibility of other radiological and nonradiological contamination, the depth distribution of contamination, and a more precise estimate of the area contaminated. The characterization activities discussed in this report were designed to address these data gaps using a phased approach that expedited gathering of the required information.

Four separate characterization events were conducted at the site from October 1994 to July 1995. During the first event, discrete soil samples were collected and analyzed for radionuclides and metals. The TCLP was also performed on several of the soil samples and the extracts were analyzed for RCRA metals. Discrete depth profile soil samples were also collected as part of the first characterization event, and these samples were analyzed for Am-241, isotopic plutonium, and isotopic uranium. Results of the first event were to identify the contaminants of potential concern and provided information on the depth of contamination in soil. The first characterization event laboratory results did not yield anticipated results. The sample results did indicate that the collection and analysis of discrete soil samples cannot cost-effectively characterize the contaminants at the site. RCRA constituents were not detected so mixed waste material is not present at the Double Tracks Test Site.

The performance of several in situ radiation measurement systems was evaluated as part of the second characterization event. During the in situ survey work, localized areas of elevated radiation "hot spots" were located and investigated by conducting in situ radiation measurements at several depths and by collecting discrete soil samples. Relatively-large, highly-radioactive metallic fragments were found at most hot spot locations. These fragments, which appear to be fragments from the Double Tracks experiment, were the primary source of radioactivity at the hot spots. When the fragments were removed and the area resurveyed, the hot spot activity generally decreased. At several sites, the surrounding soil still exhibited relatively-high levels of 
radioactivity possibly due to material spilling off the hot particle over time. Typically, this contamination was also removed by excavating a small amount of soil with the hot particle. Hot spot soil samples were collected and analyzed for Am-241, isotopic plutonium, and total uranium. In addition, several samples underwent the TCLP for RCRA metals analysis.

A systematic in situ radiological survey of the Double Tracks Test Site was performed during the third characterization event. The measurement system consisted of three pods of NaI detectors mounted on a Suburban vehicle. This system was combined with a GPS to provide both radiation measurements and locations. Prior to the survey, hot spots were identified and the highly-radioactive metallic fragments were removed and placed in a central storage location at the site. The radioactivity of the fragments was measured before storage. Several shallow soil boreholes were advanced near the Double Tracks ground zero to assess the extent of contamination in a soil mound at ground zero. Downhole radiation measurements were taken in several soil borings and indicated that radiological contamination was present within the soil mound.

The focus of the fourth characterization event was to collect soil known to be contaminated for treatability testing. Ten soil surface samples were collected in the approximate center of the contaminant plume south of ground zero. Treatability testing consisted of grain size analysis, bench scale attrition scrubbing, and gamma spectroscopy and isotopic analysis.

\subsection{Conclusions}

This report presents the results of characterization activities performed at the Double Tracks Test Site. Historical data combined with recent characterization data provided the information necessary to adequately characterize the nature and extent of contamination at Double Tracks. The interim corrective action currently planned for Double Tracks consists of removing contaminated soil and disposing of it at a permanent disposal site. The characterization data required for planning the interim corrective action included the horizontal and vertical extent of contamination, the volume of contaminated soil to be removed, waste classification data, and information to satisfy disposal criteria.

Specific conclusions on the nature and extent of contamination at the Double Tracks Test Site are as follows: 
- Contaminants of potential concern in soil at the Double Tracks Test Site are Am-241 and plutonium. Uranium and other non-radiologic metals are present only in background concentrations.

- In situ measurements indicate that typically most of the total transuranic activity is present within the top $2.5 \mathrm{~cm}$ ( 1 in.) of the soil profile. Where significant amounts of plutonium (greater than $1,000 \mathrm{pCi} / \mathrm{g}$ ) are present, it can be assumed that the uppermost $5 \mathrm{~cm}$ ( 2 in.) of the soil profile is contaminated. In the ground zero area, radiologicallycontaminated soil and possibly test debris are buried. The depth of contamination in the mound may be as thick as $0.9 \mathrm{~m}(3.0 \mathrm{ft})$.

- The contamination of surface soil at Double Tracks appears to have been caused by local fallout and debris from the experiment. Superimposed on this contamination pattern were relatively-large metallic fragments. These metallic fragments were the source of most of the radioactive hot spots activity identified during characterization.

- The surface area with total transuranic activity greater than $200 \mathrm{pCi} / \mathrm{g}$ is approximately 8,780 square meters $(95,400$ square feet), based on an in situ radiological survey.

- The best estimate of the volume of contaminated soil to be removed from Double Tracks is $1,243 \mathrm{~m}^{3}\left(1,611 \mathrm{yd}^{3}\right)$, based on a clean-up level of $200 \mathrm{pCi} / \mathrm{g}$. This estimate does not take into account soil expansion during excavation.

- Based on the contaminants present, soil from the Double Tracks Test Site would be classified as low-level radioactive waste and not mixed low-level waste. Soil contaminated with Am-241 and plutonium did not exhibit toxicity characteristics, based on TCLP data.

- The metallic fragments outside of ground zero are containerized inside the exclusion zone and represent a very small volume of transuranic material.

- Results of the treatability testing were that when the soil was separated via grain size, the contamination also separated, going into the finer fraction. After attrition scrubbing, 80 to 90 percent of the radioactive contamination is contained in the fine fraction. The fine fraction is 20 to 40 percent of the total soil mass. However, two of the ten samples had radioactive contamination present in the coarse fraction. This indicates that some of the radioactive contaminants present, outside of ground zero, are larger than fine sand. Based on this bench scale testing, volume reduction appears to be feasible with the current understanding of site characteristics. However, volume reduction does not appear to be cost effective for the Double Tracks Test Site because of the relatively small amount of soil requiring corrective action. If during the site corrective action it is determined that site conditions change, volume reduction via grain size separation may be reexamined. If volume reduction is implemented, the volume of soil requiring transportation to the disposal site will be reduced, as will the associated transportation risks. 



\subsection{References}

American Society for Testing and Materials. 1991. Trace Uranium in Water by Pulsed-Laser Fluorimetry, 5174-91. Philadelphia, PA.

American Society for Testing and Materials. 1975. Standard Recommended Practice for Dealing with Outlying Observations, E178-75. Philadelphia, PA.

ASTM, see American Society for Testing and Materials.

Church, H.W. Sandia National Laboratories. 1969. Cloud Rise from High-Explosives Detonations, SC-RR-68-903. Albuquerque, NM.

DOE, see U.S. Department of Energy.

Ekren, C.B., R.E. Anderson, C.L. Rogers, and D.C. Noble. 1971. U.S. Atomic Energy Commission. Geology of Northern Nellis Air Force Base Bombing and Gunnery Range, Nye County, Nevada. Geological Survey Professional Paper 651.

EPA, see U.S. Environmental Protection Agency.

Essington, E.H., R.O. Gilbert, L.L. Eberhardt, and E.B. Fowler. U.S. Energy Research and Development Administration, Nevada Operations Office. 1975. Plutonium, Americium, and Uranium Concentrations in Nevada Test Site Soil Profiles, LA-UR-75-1770, IAEA-SM-199/76.

Faure, G. 1986. Principles of Isotope Geology, 2nd ed., John Wiley and Sons. New York, NY.

Friesen, H.N. U.S. Department of Energy, Nevada Field Office. 1992. Summary of the Nevada Applied Ecology Group and Correlative Programs, DOE/NV-357. Las Vegas, NV.

Gilbert, R.O. 1987. Statistical Methods for Environmental Pollution Monitoring, Van Nostrand Reinhold Company, Inc. New York, NY.

Gilbert, R.O. U.S. Department of Energy, Nevada Operations Office. 1977. "Revised Total Amounts of ${ }^{239,240} \mathrm{Pu}$ in Surface Soil at Safety-Shot Sites," in Transuranics in Desert Ecosystems, NVO-181. M.G. White, P B. Dunaway, and D.L. Wireman, eds. Las Vegas, NV.

Gilbert, R.O., L.L. Eberhardt, E.B. Fowler, E.M. Romney, E.H. Essington, and J.E. Kinnear. U.S. Energy Research and Development Administration, Nevada Operations Office. 1975. "Statistical Analysis of ${ }^{239-240} \mathrm{Pu}$ and ${ }^{241} \mathrm{Am}$ Contamination of Soil and Vegetation on NAEG Study Sites," in The Radioecology of Plutonium and Other Transuranics in Desert Environments, NVO-153. M.G. White and P.B. Dunaway, eds. Las Vegas, NV. 
Glora, M.A. and I. Aoki. Reynolds Electrical \& Engineering Co., Inc. 1966. Radiological Conditions at Project Rollercoaster Sites - 1965, NVO-162-19. Radiological Sciences Department. Mercury, NV.

Glora, M.A. and B.L. Brown. Reynolds Electrical \& Engineering Co., Inc. 1964. Project Roller Coaster Quarterly Resurvey, June 1964, NVO-162-17. Radiological Sciences Department. Mercury, NV.

Hendricks, T.J. EG\&G Energy Measurements Group. 1995. An Aerial Radiological Survey of the Double Track Site and Surrounding Area, Central Nevada, EGG 11265-1466, Draft. Las Vegas, NV.

IT, see IT Corporation.

IT Corporation. 1994. Background Concentrations of Constituents of Concern to the Sandia National Laboratories/New Mexico Environmental Restoration Project, Phase II: Interim Report. Albuquerque, NM.

Jobst, J.E. EG\&G Energy Measurements Group. 1979. An Aerial Radiological Survey of Clean Slates 1, 2, and 3, and Double Track, Tonopah Test Range, Central Nevada, EGG-1183-1737. Las Vegas, NV.

Kinnison, R.R. and R.O. Gilbert. U.S. Department of Energy, Nevada Operations Office. 1982. "Estimates of Amounts of Soil Removal for Cleanup of Transuranics at NAEG Off-Site Safety-Shot Sites," in The Radioecology of Transuranics and Other Radionuclides in Desert Ecosystems, NVO-224. W.A. Howard, P.B. Dunaway, and R.G. Fuller, eds. Las Vegas, NV.

Krauskopf, K.B. 1979. Introduction to Geochemistry, 2nd ed., McGraw-Hill Book Company. New York, NY.

Leavitt, V.D. U.S. Environmental Protection Agency. 1974. Soil Surveys of Five Plutonium Contaminated Areas on the Test Range Complex in Nevada, NERC-LV-539-28, Monitoring Systems Research and Development Laboratory, National Environmental Research Center. Las Vegas, NV.

Martin, W.E. and S.G. Bloom. U.S. Energy Research and Development Administration, Nevada Operations Office. 1977. "Nevada Applied Ecology Group Model for Estimating Plutonium Transport and Dose to Man," in Transuranics in Natural Environments, NVO-178. M.G. White and P.B. Dunaway, Eds. Las Vegas, NV.

McArthur, R.D. and F.L. Miller, Jr. Desert Research Institute. 1989. Off-Site Radiation Exposure Review Project; Phase II Soils Program, DOE/NV/10384-23, Water Resources Center, University of Nevada System. Las Vegas, NV. 
Menker, H.E., J.C. Armstrong, E.J. Forslow, and B.H. Sorensen. Hazleton-Nuclear Science Corporation. 1966. Operation Roller Coaster, Project Officers Report - Project 5.2/5.3a, Radiochemical Analysis of Biological and Physical Samples, POR-2515. Palo Alto, CA.

NAS, see National Academy of Sciences.

National Academy of Sciences. 1965. The Radiochemistry of Plutonium, NAS-NS-3058. Washington, DC.

National Academy of Sciences. 1962. The Radiochemistry of Uranium, NAS-NS-3050. Washington, DC.

National Academy of Sciences. 1960. The Radiochemistry of Americium and Curium, NAS-NS-3006. Washington, DC.

Riedhauser, S.R. and W.J. Tipton. Bechtel Nevada, Remote Sensing Laboratory: 1996. In Situ Radiological Surveying at the Double Tracks Site, Nellis Air Force Range, Tonopah, Nevada, Draft. Las Vegas, NV.

Shreve, J.D., Jr. Sandia Corporation. 1965. Operation Roller Coaster, Scientific Director's Summary Report, DASA-1644. Albuquerque, NM.

Thomas, J.M., J.L. Mason, and J.D. Crabtree. U.S. Geological Survey. 1986. Ground-Water Levels in the Great Basin Region of Nevada, Utah, and Adjacent States [MAP].

U.S. Department of Energy, Nevada Operations Office. 1995a. Cost/Risk/Benefit Analysis of Alternative Cleanup Requirements for Plutonium-Contaminated Soils On and Near the Nevada Test Site, DOE/NV-399. Las Vegas, NV.

U.S. Department of Energy, Nevada Operations Office. 1995b. Soils Media Operable Unit Quality Assurance Project Plan, DOE/NV-376. Las Vegas, NV.

U.S. Department of Energy. 1992. Environmental Measurements Laboratory Procedures Manual, HASL-300, 27th ed. New York, NY.

U.S. Environmental Protection Agency. 1994. Title 40 - Protection of Environment, Part 261 Identification and Listing of Hazardous Waste, Subpart C - Characteristics of Hazardous Waste, Toxicity Characteristic (40 CFR 261.24). Washington, DC.

U.S. Environmental Protection Agency. 1993. Title 40 - Protection of Environment, Part 191 Environmental Radiation Protection Standards for Management and Disposal of Spent Nuclear Fuel, High-Level and Transuranic Radioactive Wastes, Subpart A - Environmental Standards for Management and Storage, Definitions (40 CFR 191.02). Washington, DC. 
U.S. Environmental Protection Agency. 1990a. USEPA Contract Laboratory Program Statement of Work for Inorganics Analysis, Multi-Media, Multi-Concentration, ILM01.0. Washington, DC.

U.S. Environmental Protection Agency. 1990b. Test Methods for Evaluating Solid Waste, Physical/Chemical Methods, SW-846, 3rd ed., Final Update 1. Washington, DC.

U.S. Environmental Protection Agency. 1989. Statistical Analysis of Ground-Water Monitoring Data at RCRA Facilities, EPA/530-SW-89-026, Interim Final Guidance, Office of Solid Waste, Waste Management Division. Washington, DC. 
Appendix A

IT Field Sampling Instructions 



\title{
FIELD SAMPLING INSTRUCTION DOUBLE TRACKS SITE SCOPING STUDY
}

\author{
Prepured for \\ DOE Nevada Operations Office \\ Las Vegas. Nevada \\ Prepured by \\ IT CORPORATION \\ 4330 South Valley. View Boulevard. Suite 114 \\ Las Vegas. Nevada \\ Work Performed Under Contract No. \\ DE-AC08-92NV 10972
}

October 1994 
This report has been reproduced from the best available copy. For availability contact:

Office of Scientific and Technical Information

P.O. Box 62

Oak Ridge, TN 37831 (615) 576-8401 


\section{DISCLAIMER}

This report was prepared as an account of work sponsored by the L'nited States Government. Veither the United States nor the United States Department of Energy, nor any of their employees. makes a warranty, express or implied. or assumes any legal liability or responsibility for the accuracy, completeness or usefulness of any information. apparatus. product or process disclosed. or represents that its use would not infringe privately owned rights. Reference herein to any specific commercial products. process, or service by trade name. mark. manufacturer. or otherwise. does not necessarily constitute or imply its endorsement. recommendation. or favoring by the United States Government or any agency thereof. The views and opinions of authors expressed herein do not necessarily state or reflect those of the United States Government or any agency thereot. 



\section{FIELD SAMPLIN(; INSTRUCTION \\ DOUBLE TRACKS SITE \\ SCOPING STUDY}
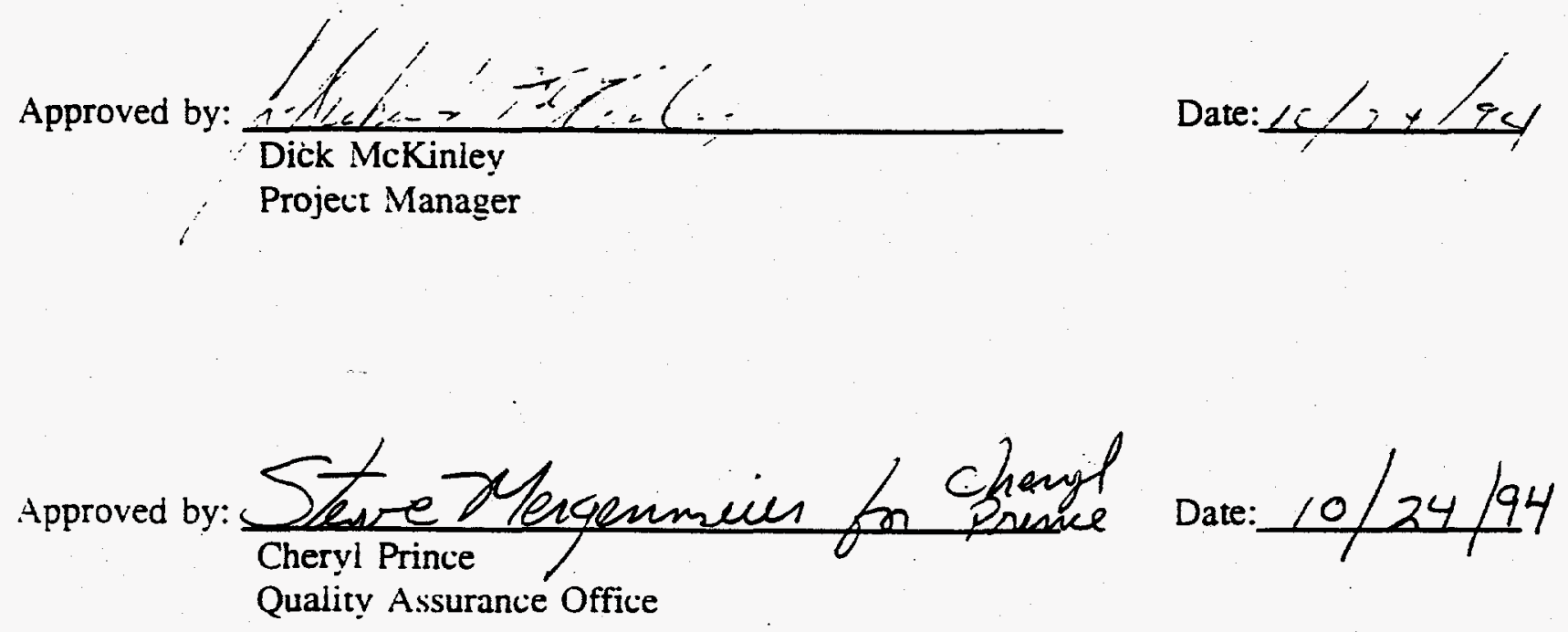



\section{Table of Contents}

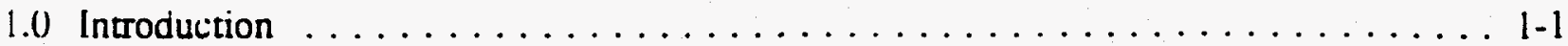

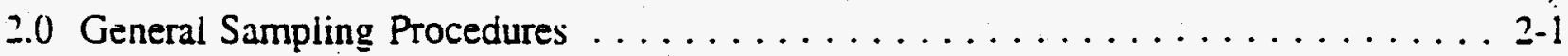

2.1 Sample Locations $\ldots \ldots \ldots \ldots \ldots \ldots \ldots \ldots \ldots \ldots \ldots \ldots \ldots \ldots \ldots \ldots \ldots \ldots \ldots \ldots .1$

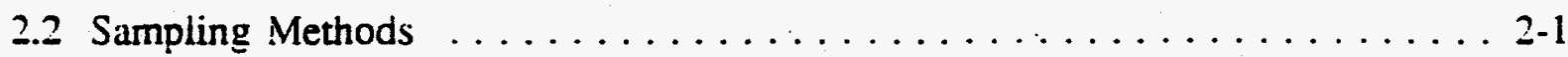

2.3 Sample Handling. Packaging. and Shipping $\ldots \ldots \ldots \ldots \ldots \ldots \ldots \ldots \ldots \ldots \ldots$

2.4 Quality Control Samples ...................... 2-4

2.4.1 Equipment Rinsate Blank Samples . . . . . . . . . . . . 2 2-5

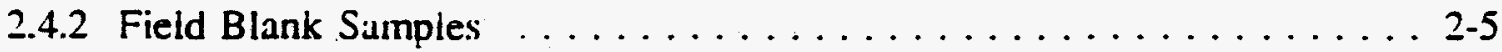

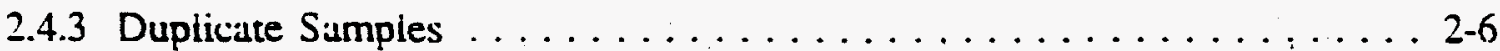

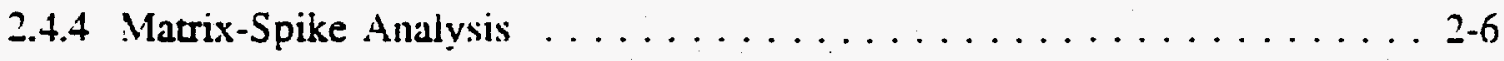

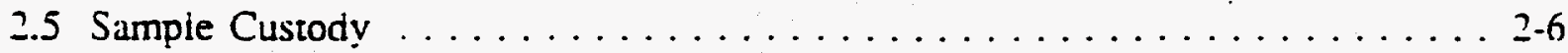

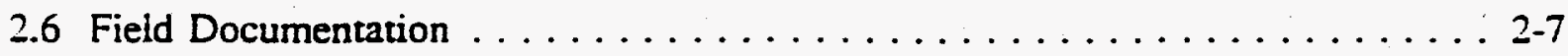

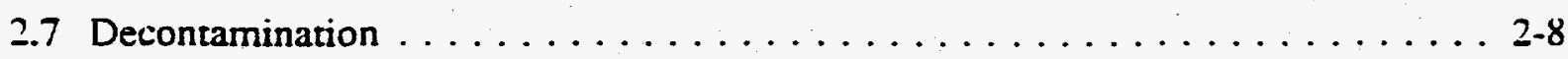

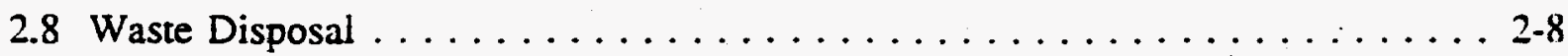

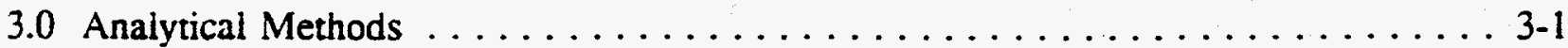

3.1 Resource Conservation Recovery Act Metals . . . . . . . . . . . . 3-1

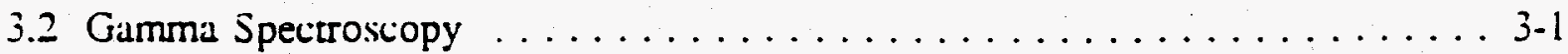

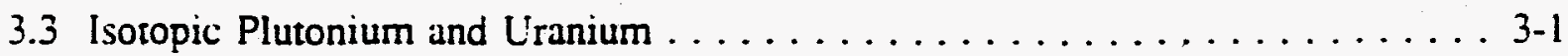

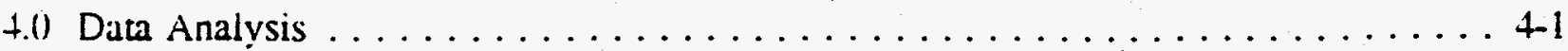

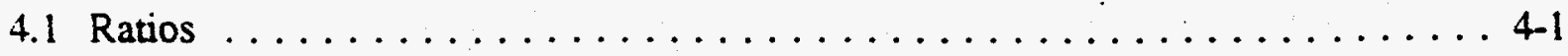

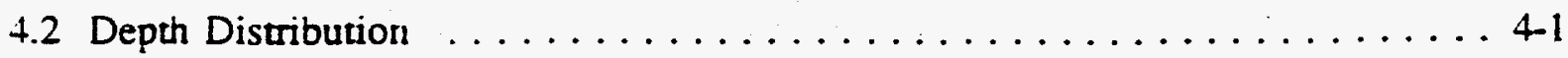

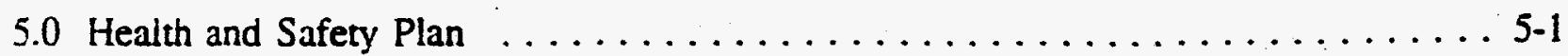

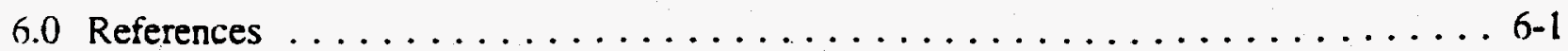

Appendix A - Site Specific Health and Safety Plan $\ldots \ldots \ldots \ldots \ldots \ldots \ldots \ldots \ldots \ldots$ 


\section{List of Figures}

Number

2-1 Approximate Sample Locations for Scoping Study

Double Tracks. Nellis Air Force Range

\section{List of Tables}

Number

2-1 Sample Container. Preservation. and Holding-Time Requirements for Soil Samples and Field Blank Sampies

2-2 Sample Container. Preservation. and Holding-Time Requirements

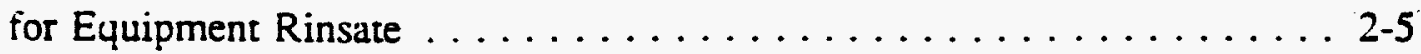

i-1 Analytical Methods and Quality Assurance Criteria $\ldots \ldots \ldots \ldots \ldots$ 3-2

3-2 Practical Quantitation Limits for the Analysis of Metals by the Toxicity Characteristic Leaching Procedure

3-3 Target Detection Limits for Radionuclides by Gamma Spectroscopy in Soil and Water Sumples 


\section{List of Acronyms and Abbreviations}

AR/COC Analysis Request and Chain of Custody Form

$\mathrm{cm}$

centimeter.

DOE

U.S. Department of Energy

FADL

Field Activity Daily Log

in.

inch

ine

milliliter

NAFR

Nellis Air Force Range

NV ERP

Nevada Environmental Restoration Project

oz

ounce

$\mathrm{pCi} / \underline{\mathrm{g}}$

picocuries per gram

PQL

practical quantitation limits

$\mathrm{Pu}$

plutonium

QC

quality control

QAPjP

Quality Assurance Project. Plan

RCRA

Resource Conservation and Recovery Act

SMOU

Soils Media Operable Unit

SQP

Standard Quality Practice

SSHASP

Site-Specific Health and Safery Plan

TAL

Target Anaiyte List

TCLP

Toxicity Characteristic Leaching Procedure

$\mathrm{U}$

uranium 



\subsection{Introduction}

The Double Tracks site located on Stonewall Flat in Subrange 71 of the Nellis Air Force Range (NAFR) was used for one of four safety-shot tests performed for the Operation Roller Coaster testing series in 1963. Plutonium $(\mathrm{Pu})$ and uranium $(U)$ were used in the four tests to study the mechanisms of dispersal. transpor. and deposition of the radioactive elements from nonnuclear detonations of plutonium-bearing devices (Shreve. 1965). No nuclear yield resulted from these tests. but large land areas were contaminated with plutonium and uranium. This contamination is primarily within the top 3 centimeters (cm) to $5 \mathrm{~cm}(1.2$ inches [in.] to 2 in.) of soil (SNL. 1982).

The Double Tracks satety test consisted of a one-point detonation of a plutonium-uranium device. The test was conducted at the land surrace on a concrete and metal pad. The detonation threw weapons material. earth. and other material into the air. The debris and most of the dirt fell to earth at relatively short distances from the detonation point: however. some of the material was spread downwind over larger areas. No decontamination or cleanup activities occurred at the test site (Martin. 1989).

This field instruction for the collection of scoping samples at the Double Tracks site is designed for collecting and analyzing an adequate number of samples to provide surficient intormution for Double Tracks characterization scoping activities. Analysis of scoping samples will facilitate designing characterization sampling activities by providing information relative to selection of sampling methodology and the vertical distribution of radiological and nonradiological parameters.

This field instruction shall be used only in conjunction with. and as a supplement to. the Soils Media Operable U'nit (SMOU) Quality Assurance Project Plan (QAPjP). Each field worker's familiarity with this plan and instructions shall be documented by the completion of a Required Reading Checklist. which shall include the QAPjP, the Site-Specific Health and Safety Plan. this field instruction, and any Standard Quality Practices (SQPs) referenced herein. 



\subsection{General Sampling Procedures}

This section outlines the sampling methods that will be used at the Double Tracks site for scoping surveys.

Sampling equipment shall be decontaminated before mobilization to the field. using procedures given in SQP ITLV-0405. Sampling Equipment Decontamination. Soil samples must be collected and packaged in accordance with the SMOU QAPjP: SQP ITLV-0605. Vertical Profile Soil Sampling: and SQP ITLV-0403. Sample Handling. Packaging and Shipping.

\subsection{Sample Locations}

Sampling locations are outlined on Figure 2-1. Three transects will be used for the sumple locations that will run west to east downwind of ground zero. Sampie lociations were chosen to bias sample results for higher radiological and metal parameter levels.

\subsection{Sampling Methods}

Radiological contamination is relatively widespread in surtace soil at the Double Tracks site. However, a limited investigation performed by the Nevada Applied Ecology Group showed that the contamination is limited to the uppermost soil protile. To determine the vertical migration of the Pu. vertical-prorile soil samples snuil be collected and andiged at all sample locations.

To collect soil samples. the sampiing team shall approximately locate and mark with a wooden stake each sample site shown in Figure 2-1. Sample locations may change if it is determined by the Field Supervisor that the location is inadequate for sampling. Sample locations shall be thoroughly documented in the Field Activity Daily Log (FADL) and will be surveyed to determine Nevada grid coordinates at a later date. Samples shall be collected in accordance with SQP ITLV-0605. Four separate intervals (subsamples) shall be collected from each soil-sample site. These vertical intervals are as follows:

- $0 \mathrm{~cm}$ to $5 \mathrm{~cm}(0)$ in. to 2 in.)

- $5 \mathrm{~cm}$ to $10 \mathrm{~cm}(2 \mathrm{in}$. to $4 \mathrm{in.})$

- $10 \mathrm{~cm}$ to $15 \mathrm{~cm}$ (4 in. to 6 in.)

- $\quad 22.5 \mathrm{~cm}$ to $30 \mathrm{~cm}(9$ in. to 12 in. $)$. 



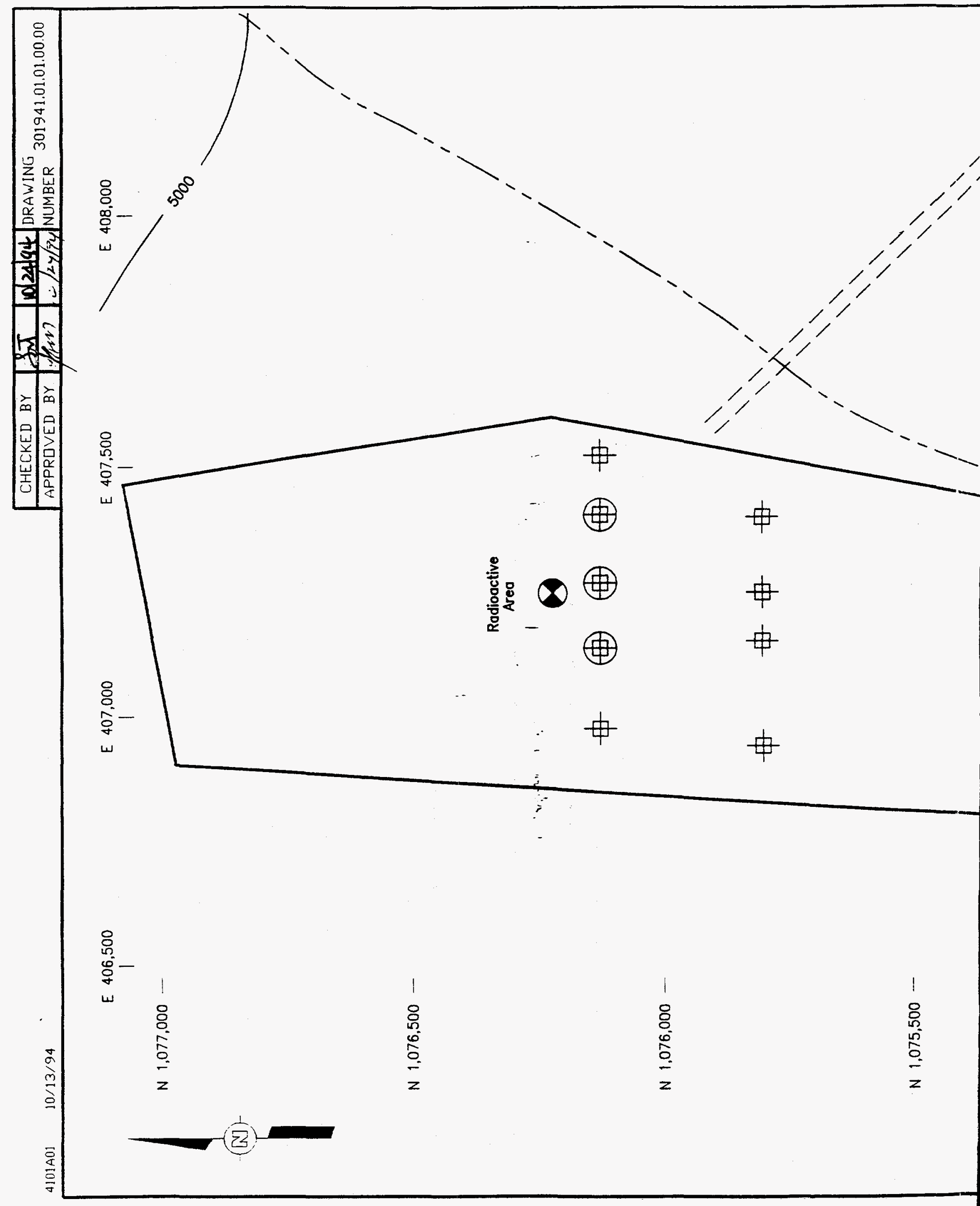


At each sample location and for each depth interval enough soil shall be collected to till two containers: one 1.000-milliliter $(\mathrm{ml})$ container and one $x$ ounce $(0 z)$ container. These sample containers shall be submitted for analysis of the parameters listed in Table $2-1$ and explained in Section 3.0. The fourth interval samples will not be sent to the lab for analysis. They will be archived until laboratory analysis results are received from the upper interval samples.

Table 2-1

Sample Container, Preservation, and

Holding-Time Requirements for Soil Samples and Field Blank Samples

\begin{tabular}{|c|c|c|c|}
\hline Parameter & $\begin{array}{c}\text { Container Type } \\
\text { Sample Volume }\end{array}$ & Preservation $^{\mathrm{a}}$ & $\begin{array}{c}\text { Maximum Holding } \\
\text { Time }^{\mathrm{b}}\end{array}$ \\
\hline $\begin{array}{c}\text { Radionuclides: } \\
\text { Gamma Spec }\end{array}$ & $\begin{array}{c}\text { 1.000-miltiliter (mel glass } \\
\text { or polyethylene. wide- } \\
\text { mouth }\end{array}$ & none required & 180 days \\
\hline $\begin{array}{c}\text { Total TALc Metals. } \\
\text { TCLPo Metals. and } \\
\text { Isotopic U. PU. and Am }\end{array}$ & 8-ounce amber giass & cool. $4^{\circ} \mathrm{C}$ & 180 days $^{\mathrm{t}}$ \\
\hline
\end{tabular}

${ }^{a}$ Temperature Note: All samples requiring temperature preservation stated at 4 Celsius (C) will be acceptable within the range of $4^{\circ} \mathrm{C} \pm 2^{\circ} \mathrm{C}$. The laboratory should note on the sample Chain-ot-custody Form that temperature reauirements were met by noting the receipt temperature. For all samples received outside the range of $4^{\circ} \mathrm{C} \pm 2^{\circ} \mathrm{C}$. the sample(s) and the temperature (in $1^{\circ} \mathrm{C}$ increments) will be noted on the Chain-ot-custody Form. and the Project Manager shall be noufied immeaiately.

THolding times are calculated trom time of sample collection.

:Target Analvie List.

:Toxicity Characteristic Leaching Proceoure.

Uranium. piutonium. and amencium.

'For TCLP. except tor mercury. hoiding ume from fieid collecton to extracton is 180 days. and holding tume from extractuon to anatysis is 180 days ( 360 days total elapsed time). For TCLP mercury. corresponoing hoiding times are 28 and 28 days 56 days total elapsed tmel.

At sample locations where the surface is armored with gravel (desert pavement). the gravel shall be removed prior to sample collection. Also. cobbles and coarse gravel (diameter $\geq 2 \mathrm{~cm}$ [0.8 in.]) shall be removed from samples. regardless of the depth at which they occur. The total sample depth. $30 \mathrm{~cm}$ (12 in.), is assumed to be sufficient because downward transport of metals and radionuclides in soil under arid and semiarid conditions has been shown by other similar studies to be minimal.

\subsection{Sample Handling, Packaging, and Shipping}

Soil samples shall be handled. packaged. and shipped in accordance with SQP ITLV-0403. The required sample containers and volumes. preservation procedures. and holding times for the analysis of soil samples are given in Table 2-1. Sample containers shall be obtained from 
un approved laboratory and certified clean as per L.S. Environmental Protection Agency protocol. The containers shall remain sealed until they are used.

Immediately after collection. the sample containers shall be labeled with black waterproof markers with. at a minimum. the following information:

- Unique identification number (assigned by program sample coordinator)

- Project name and number

- Date and time (military) of the sample collection

- Sampie location

- Sample depth interval (e.g., 0 in. to 2 in.)

- Sample medium

- Requested analyses

- Preservation

- Bottie number

- Namets) of the initial sampie custodians (collectors).

Filled sample containers shall be packaged in a shipping container as described in SQP ITLV1403. The shipping container and the outside surface of filled sample bottles shall be screened for radiological contamination either in the field or at a designated location by qualified IT or contractor personnel. Radiological screening procedures used shall be in compliance with U.S. Department of Energy (DOE) requirements and U.S. Department of Transportation regulations.

Documentation of sample handling, packaging. and shipping shall be completed daily. in ink. by the soil sampling team in accordance with SQP ITLV-(1401). Field Activities Documentarion.

\subsection{Quality Control Samples}

Fieid and laboratory investigation activities shall include the collection and analysis of quality control (QC) samples to determine whether data generated meet the data quality criteria of this scoping survey. These samples shall be introduced into the analytical process in order to assess the overall quality of the sampling and analysis program. Samples will be collected in compliance with the QAPjP and SQP ITLV-0404. Collection of Field Quality Control Samples. This section describes the QC samples that will be generated from the scoping survey field activities. 


\subsubsection{Equipment Rinsate Blank Samples}

To assess the overail cleanliness of the sumpling system and the effectiveness of samplingequipment decontamination procedures. a minimum of one equipment rinsate blank shall be submitted to the laboratory for each day of sampling activity requiring equipment decontamination. The blanks shail be prepared by pouring deionized water through or over a decontaminated sampling device prior to the use of the device for environmental sample collection. Enough rinsate must be generated to till four 1.000-m $\ell$ containers. Equipment rinsates shall be analyzed for the parameters in Table 2-2. If rinsate blank analytical results indicate possible contamination of samples. environmental sample results shall be reviewed to determine whether qualifiers should be assigned to the data or corrective action would be required.

Table 2-2

Sample Container, Preservation. and Holding-Time Requirements for Equipment Rinsate

\begin{tabular}{|c|c|c|c|}
\hline Parameter & $\begin{array}{l}\text { Container Type/ } \\
\text { Sample Volume }\end{array}$ & Preservation $^{a}$ & $\begin{array}{c}\text { Maximum Holding } \\
\text { Time }^{b}\end{array}$ \\
\hline $\begin{array}{l}\text { Radionuclides: } \\
\text { Gamma Spec }\end{array}$ & $\begin{array}{c}\text { 1.000-milliliter } \\
\text { (me) } \\
\text { polyethyiene }\end{array}$ & $\begin{array}{c}\text { cool. } 4^{\circ} \mathrm{C} \\
\mathrm{pH} \leq 2 \text { with } \mathrm{HNO}_{3}\end{array}$ & 180 days \\
\hline Total TAL ${ }^{c}$ Metals & $\begin{array}{c}1.000-m e \text { amber } \\
\text { glass }\end{array}$ & $\begin{array}{c}\text { cool. } 4^{\circ} \mathrm{C}: \\
\mathrm{pH} \leq 2 \text { with } \mathrm{HNO}_{3}\end{array}$ & 180 days \\
\hline Isotopic Uranium & $\begin{array}{c}1.000-\mathrm{me} \\
\text { polyethylene }\end{array}$ & $\begin{array}{c}\text { cool. } 4^{\circ} \mathrm{C}: \\
\mathrm{pH} \leq 2 \text { with } \mathrm{HNO}_{3}\end{array}$ & 180 days \\
\hline $\begin{array}{l}\text { Isotopic Plutonium. } \\
\text { and Americium }\end{array}$ & $\begin{array}{c}1.000-\mathrm{me} \\
\text { polyethylene }\end{array}$ & $\begin{array}{c}\text { cool. } 4^{\circ} \mathrm{C}: \\
\mathrm{pH} \leq 2 \text { with } \mathrm{HNO}_{3}\end{array}$ & 180 days \\
\hline
\end{tabular}

'Temperature Note: All samples requiring temperature preservation stated at $4^{\circ}$ Celsius $(C)$ will be acceptable within the range of $4^{\circ} \mathrm{C} \pm 2^{\circ} \mathrm{C}$. The laboratory should note on the sample Chain-of-custody form that temperature requirements were met by noting the receipt temperature. For all samples received outside the range of $4^{\circ} \mathrm{C} \pm 2^{\circ} \mathrm{C}$, the sample(s) and the temperature (in $1^{\circ} \mathrm{C}$ increments) will be noted on the Chain-ot-custody Form. and the Project Manager shall be notfied immediately.

Folding umes are calculated trom time of sampie collection.

-Target Analyte List.

\subsubsection{Field Blank Samples}

Field blanks shall be collected at a minimum of one per day. If weather conditions change ignificantly during sampling. an additional field blank shall be collected. Field blanks shall be collected and analyzed to determine if contamination in the air during sample collection and packaging may have contaminated the samples. The field blanks shall be prepared by 
pouring certified clean sand into clean sumpie containers in the field near the sampling locations. Field blanks shall be analyzed for the parameters in Tuble 2-1. If field blank analytical results indicate possible contamination of associated sampies. environmental sample resuits shall be reviewed to determine whether qualifiers should be assigned to the data or corrective action is required.

\subsubsection{Duplicate Samples}

To assess sample variability. duplicate samples shall be collected at a minimum of 1 per group of 20 samples. The duplicates shall be obtained from the same depth horizon and approximately the same horizontal position as the original sample. A unique sample number shall be assigned to the duplicate sample. The duplicate sample number shall not indicate that it is a QC sample to minimize handling. analysis. and data-evaluation bias. Duplicates shall be analyzed for the parameters in Table 2-1.

\subsubsection{Matrix-Spike Analysis}

For metal analysis. a sample shall be designated on an Analysis Request and Chain of Custody (AR/COC) Form for matrix-spike analysis for each matrix. One matrix spike will be designated per 20 samples collected. The sumple will be spiked with the analytes of interest at the laboratory and analyzed with each batch of samples. Matrix-spike sumpies shall be analyzed to determine interferences of the sample matrix on the analytical methods.

\subsection{Sample Custody}

The validity of environmental measurement data is dependent upon the ability to demonstrate that samples have been obtained from the locations stated and that they have reached the laboratory without alteration except by required preservation. The procedures for initiating. maintaining. and documenting sample chain of custody are defined by SQP ITLV-0402. Chain of Custody. An AR/COC Form shall be used to record custody transfers by field personnel responsible for transporting samples. The term "chain of custody" reters to the method by which the sample history is tracked and continuous possession of a sample by approved personnel (custodian) is documented. The AR/COC Form makes the sample a legally defensible entity. Chain of custody shall be initiated in the field by the person collecting samples. L'se of the AR/COC Form is required without exception to create a written record of sample custody from the time of collection through laboratory analysis. All iamples. inciuding fïeld QC samples. shall be recorded on the AR/COC Form. Samples will not be analyzed by the laboratory without a correctly prepared AR/COC Form. Materials that 
thall be used in the chain-of-custody process for sample tracking and field actrvities are as follows:

- Sample Identification Labei

- AR/COC Form

- Custody Seal Tupe.

Examples of these forms and instructions for their use are presented in SQPS ITLV-04()1. ITLV-0402. and ITLV-(04)3.

\subsection{Field Documentation}

Field activities and sample collection shall be documented in accordance with SQP ITLV-(1)4(1)1. At a ininimum. field documentation for the soil sampling effort shall be comprised of the following:

- FADL

- Tailgate Safety Briefing Form

- Equipment Calibration Form (for health and safety monitoring instruments)

- Sample Collection Log.

Sample collection logs shall be completed immediately after sample collection and contain the following information. at a minimum:

- Unique identification number (assigned by program sample coordinator)

- Project name and number

- Date and time (military) of the sample collection

- Sample location (e.g., BM-YF-1-1), with a drawing if appropriate

- Sample depth interval (e.g.. 0 in. to 2 in.)

- Sample type (e.g.. duplicate or rinsate)

- Physical description of sample

- Background area name

- Amount of sample collected and container type

- Signature(s) of the sample collectors.

If duplicate samples are collected. the unique identification number of the second sample shall be recorded on the sample collection log. The physical description of the sample should include the following. as applicable:

- Overall sample grain size

- Soil color

- Lithology of tloat at the sampie site 
- Removal of surface igravel or deser pavement prior to sampling

- Sedimentary environment (e.g.. active wash. channel. inactive surtace. and desert varnish)

- Presence of distinct or unusual soil lavers or horizons

- Suspected contaminarion

- Disturbed sample site.

All field documentation shall be completed daily, in ink. by the soil sampling team. Field records shall be collected and maintained by the IT Project Manager or designee until completion of the field program or until they are submitted to the project files.

\subsection{Decontamination}

Decontamination of sampling equipment shall be performed according to SQP ITLV-(0405. Sampling equipment shall be decontaminated in the fieid between collection of sampies. and waste from decontamination shall be disposed according to the procedure discussed in Section 2.8. Personner decontamination requirements are specified in the Nevada Environmental Restoration Project (NV ERP) Health and Safety Plan (DOE. 1994) and the Site-Specific Heaith and Safety Plan (SSHASP) that is included as an attactment to this field instruction.

\subsection{Waste Disposal}

This subproject will result in the generation of investigation-derived waste. The waste shall be cutegorized as sanitary, hazardous. radioactive. or mixed a combination of radioactive and hazardousı. Waste shall be categorized through process knowledge and/or sampling analysis.

Disposal of field-derived waste from the NAFR shall be in accordance with written. approved operating procedures. These procedures ensure that field-derived waste shall be managed in accordance with applicable federal and state of Nevada regulations. as well as DOE requirements. Field-derived waste shall be minimized to the greatest extent possible through process controls. control of hazardous materials. and segregation of waste.

If waste is shown to be low-level radioactive waste. solid (i.e.. nonliquid) field-derived waste (e.g., personal protective and sampling equipment and disposable wipes) shall be appropriately segregated into items which are amenable to decontamination and which are not. Items amenable to decontamination. such as cloth coveralls. shall be transported to the NTS Area 6 Decontamination Facility. Items not amenable to decontamination shall be managed in accordance with the approved Reynolds Electrical \& Engineering Co.. Inc.. low-level 
compactable trash waste stream. Liquid waste. such as decontamination rinsate. shall be containerized and left on site pending additional sampling activities and the construction of an on-site decontamination tacility.

Sunitary, nonradioactive solid waste shall be disposed in an approved sanitary landfill: liquids will be evaporated or discharged to an approved sanitary sewer.

Mixed waste. if generated. shall be ransported to the NTS Area 5 Transuranic Waste Storage Pad in accordance with the provisions of the consent order between DOE and the state of Nevada. Hazardous waste. if generated. shall be accumulated on site pending accumulation of 55 gallons. Upon aciumulation of 55 or more gallons of hazardous waste. the waste shall be held for less than 90 days pending transport to a permitted off-site treatment. storage, and disposal facility in accordance with federal and state regulations. 



\subsection{Analytical Methods}

Table 3-1 lists the anaiytical methods and equipment and the acceptance criteria for precision. accuracy. and completeness. While acceptance criteria are also presented in the QAPjP. more detailed criteria are presented in this field instruction.

\subsection{Resource Conservation Recovery Act Metals}

The soil samples shall be analyzed for total target analyte list (TAL) metals using inductively coupled-atomic emission spectroscopy and cold vapor atomic absorption spectrometry for mercury. Three surface samples. as shown in Figure 2-1, will also undergo toxicity characteristic leaching procedure (TCLP) analysis ior Resource Conservation Recovery Act (RCRA) metals (Title 4 () CFR Appendix II) to provide information relative to future soil waste disposal requirements. The list of RCRA metals and practical quantitation limits (PQL) ure shown in Tuble $:=2$. The PQLs are surficient to yuantury the concentration of RCRA metals in the TCLP extract.

\subsection{Gamma Spectroscopy}

A gamma spectroscopic method from the Environmental Measurements Laboratory Procedures Manual (HASL-300) (DOE. 1992a) shall be used to analyze the soil samples for radiological parameters. Radiological analytes and target detection limits are presented in Table 3-3. In generui. target detection limits were selected to provide enough sensitivity to ensure that soil samples were not contaminated by testing-related radionuclides. The target detection limits were selected so that global fallout levels of Cesium-137. 0.2 picocuries per gram (pCi/g) to $0.4 \mathrm{pCi} / \mathrm{g}$ (EG\&G. 1985). and naturally-occurring levels of other radionuclides. (e.g., $0.3 \mathrm{pCi} / \mathrm{g}$ to $1.3 \mathrm{pCi} / \mathrm{g}$ U-238 [EG\&G. 1985]), shall be quantified in soil sampies.

\subsection{Isotopic Plutonium, Uranium, and Americium}

Soil samples analysis for isotopic uranium and plutonium and americium-241 shall be performed in accordance with the National Academy of Science Nuclear Series procedure 3050 (1962) for uranium. 3058 for plutonium. (1965). and 3006 for americium. Soil aliquots will undergo several stages of dissolution using nitric. hydrofluoric. and hydrochloric acids and hydrogen peroxide. The solution will be introduced onto an ion exchange column. and the elements of concern will be eluted from the column with an acid solution. This solution will undergo further treatment so that the elements of concern form a precipitate that will be riltered and mounted on a stainless-steel disk for alpha counting. 
Table 3-1

Analytical Methods and Quality Assurance Criteria

\begin{tabular}{|c|c|c|c|c|c|c|}
\hline Paramelers & Medium & $\begin{array}{l}\text { Analytical } \\
\text { Methods }\end{array}$ & $\begin{array}{l}\text { Analytical } \\
\text { Equipment }\end{array}$ & $\begin{array}{l}\text { Precision } \\
\text { Criteria } \\
\text { (RPD) }\end{array}$ & $\begin{array}{c}\text { Accuracy } \\
\text { Crileria } \\
\text { (Percent Recovery) }\end{array}$ & $\begin{array}{c}\text { Completeness } \\
\text { (Percent) }\end{array}$ \\
\hline \multirow[t]{2}{*}{ Total TAL Metals ${ }^{b}$} & soil & $\begin{array}{c}\text { EPA } 60100^{c} \\
\text { EPA } 7470 \text { lor Mercury }\end{array}$ & ICP $^{\circ}$. CVAA & $\pm 35^{1}$ & 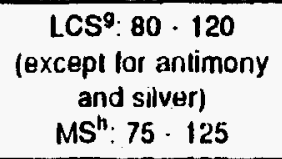 & 90 \\
\hline & water & $\begin{array}{l}\text { EPA } 6010 \text {. } \\
\text { EPA } 7470 \text { for Mercury }\end{array}$ & ICP. CVAA &. $\pm 20^{\prime}$ & $\begin{array}{c}\text { LCS: } 80 \cdot 120 \\
\text { (except for antimony } \\
\text { and silver) } \\
\text { MS. } 75 \cdot 125\end{array}$ & 90 \\
\hline \multirow[t]{2}{*}{ Radionuclides } & soil & $\begin{array}{l}\text { HASL-300' } \\
4.5 .2 .3\end{array}$ & $\begin{array}{c}\text { gamma } \\
\text { spectrometer }\end{array}$ & $\begin{array}{c} \pm 1.5 \times 2 \sigma \text { error of } \\
\text { sample }\end{array}$ & $\begin{array}{l} \pm \text { 3o mean recovery } \\
\text { from control tables }\end{array}$ & 90 \\
\hline & water & $\begin{array}{c}\text { HASL-300 } \\
4.5 .2 .3 \\
\end{array}$ & $\begin{array}{c}\text { gamma } \\
\text { spectrometer }\end{array}$ & $\begin{array}{c} \pm 15 \times 20 \text { error of } \\
\text { sample }\end{array}$ & $\begin{array}{l} \pm 3 \sigma \text { mean recovery } \\
\text { from control tables }\end{array}$ & 90 \\
\hline \multirow{2}{*}{$\begin{array}{c}\text { TCLP' } \\
\text { RCAA Metals } \\
\text { - }\end{array}$} & soil & Extraction: EPA 1311 & $\mathrm{NA}^{\mathrm{m}}$ & NA & NA & 90 \\
\hline & extracl & $\begin{array}{l}\text { EPA } 6010 \text {, } \\
\text { EPA } 7060 \text { lor arsenic, } \\
\text { EPA } 7421 \text { for lead. } \\
\text { EPA } 7470 \text { lor mercury. } \\
\text { EPA } 7740 \text { lor selenium }\end{array}$ & $\begin{array}{l}\text { ICP, CVAA } \\
\text { GFAA' }\end{array}$ & $\pm 20^{n}$ & $\begin{array}{l}\text { LCS: } 80 \cdot 120 \\
\text { MS: } 75 \cdot 125\end{array}$ & 90 \\
\hline \multirow[t]{2}{*}{ Isolopic U } & water & NAS NS 3050 & alpha spectrometer & \pm 20 & LCS: $75 \cdot 125$ & 90 \\
\hline & soil & NAS NS 3050 & alpha spectrometer & \pm 20 & LCS: $75 \cdot 125$ & 90 \\
\hline \multirow[t]{2}{*}{ Isotopic Pu } & waler & NAS NS 3058 & alpha spectrometer & 125 & LCS: $75 \cdot 125$ & 90 \\
\hline & soil & NAS NS 3058 & alpha spectrometer & \pm 35 & LCS: $75 \cdot 125$ & 90 \\
\hline \multirow[t]{2}{*}{ Am.241 } & waler & NAS NS 3006 & alpha spectrometer & \pm 50 & LCS: $75-125$ & 90 \\
\hline & soil & NAS NS 3006 & alpha spectrometer & 150 & LCS $75 \cdot 125$ & 90 \\
\hline
\end{tabular}

"Relative percent dilference.

Target Analyte LIs!.

'U.S. Environmental Prolection Agency, 1992

Inductively caupled argon plasma spectroscopy.

- Cold vapor atomic absorption spectroscopy

'RPD lor sample values greater than five times the Contract Required Detection Limit

(CRDL). For sample values less than five times the CRDL, the criterion is

\pm CRDL for water and \pm 2 times the CADL for soil.

Uaboratory control sample.
"Matrix spike sample

'Graphite furriace atomic absorption spectroscopy

U.S. Department of Energy, 1992a.

${ }^{k}$ Expressed in the same units as analylical results $(\theta \mathrm{g}$. picocuries per gram)

'Toxicity Characteristic Leaching Procedure.

"Not applicable

"Applicable only to sample values greater than 10 times the instrument detection

- National Academy of Science Nuclear Series 
Table 3-2

Practical Quantitation Limits for the Analysis of Metals

by the Toxicity Characteristic Leaching Procedure

\begin{tabular}{|c|c|c|}
\hline Element $^{\circ}$ & CAS $^{c}$ Number & $\begin{array}{c}\text { Practical Quantitation Limits } \\
(\mu g /)^{d}\end{array}$ \\
\hline Arsenic $^{\circ}$ & $7440-38-2$ & 3 \\
\hline Barium & $7440-39-3$ & 10 \\
\hline Cadmium & $7440-43-9$ & 10 \\
\hline Chromium $^{\text {Cead }}$ & $7440-47-3$ & 25 \\
\hline Mercury $^{t}$ & $7439-92-1$ & 3 \\
\hline Selenium & & 0.2 \\
\hline Silver & $7439-97-6$ & 3 \\
\hline
\end{tabular}

IT, 1993.

'Analyzed by inductively coupled argon plasma spectroscopy. untess noted.

"Chemical Abstract Service.

oMicrograms per liter.

-Analyzed by graphite tumace atomic absorpion spectroscopy

'Analyzed by cold vapor atomic absorpton spectroscopy. 
Table 3-3

Target Detection Limits for Radionuclides by Gamma Spectroscopy in Soil and Water Samples

\begin{tabular}{|c|c|c|}
\hline Radionuctide & $\begin{array}{c}\text { Target Detection Limit for Soil } \\
\text { Samples } \\
(p \text { Cig })^{2}\end{array}$ & $\begin{array}{l}\text { Target Detection Limit for Weter } \\
\text { Samples } \\
(\mathrm{pCi} /)^{\circ}\end{array}$ \\
\hline Actnium-227 & 0.6 & $N^{c}$ \\
\hline Antimony-125 & 0.2 & 25 \\
\hline Amencium-241 & 0.6 & NA \\
\hline Barium-133 & 0.1 & 10 \\
\hline Bismuth-214 & 0.2 & 25 \\
\hline Cobatt 60 & 0.1 & 10 \\
\hline Cesium-137 & 0.1 & 10 \\
\hline Eurootum-152 & 0.2 & 25 \\
\hline Europium-154- & 0.2 & 25 \\
\hline Europium-155 & 0.4 & 25 \\
\hline Lead-210 & 5 & NA \\
\hline Lead-212 & 0.1 & 25 \\
\hline Potassium-40 & 1 & NA \\
\hline Protacunium-231 & 3 & NA \\
\hline Protactunium-234 & 18 & NA \\
\hline Radium-223 & 0.6 & so \\
\hline Padium-226 & 0.2 & 25 \\
\hline Thailium-208 & 0.1 & 10 \\
\hline Thonum-232 & 0.6 & NA \\
\hline Uranium-234 & 0.6 & NA \\
\hline Uranium-235 & 0.6 & NA \\
\hline Uranium-238 & 0.6 & NA \\
\hline
\end{tabular}

${ }^{3}$ Picocunes per gram.

ipicocunes per liter.

-Not appitcabie. Detecton limits in water are relativeiy high and are not applicabie to QC sampies. 


\subsection{Data Analysis}

Analytical data will be reviewed by the project manager for completeness and accuracy prior to conducting data analysis. The following will be culculated and reported for the Double Tracks site for use in the characterization report.

\subsection{Ratios}

The average ratios of ${ }^{239.210} \mathrm{Pu}$ to ${ }^{2+1} \mathrm{Am}$ and ${ }^{239.240} \mathrm{Pu}$ to ${ }^{2: 3} \mathrm{U}$ shall be computed using:

$$
b=\sum_{i=1}^{n} y_{i} / \sum_{i=1}^{n} x_{i}
$$

where $y_{i}$ is the ${ }^{239.2+0} \mathrm{Pu}^{-}(\mathrm{pCi} / \mathrm{g})$ concentration. and $\mathrm{x}_{\mathrm{i}}$ is the ${ }^{2+1} \mathrm{Am}(\mathrm{pCi} / \mathrm{g})$ or ${ }^{233} \mathrm{U}(\mathrm{pCi} / \mathrm{g})$ concentration for the $\mathrm{i}^{\text {th }}$ soil sample collected at Double Tracks. All ratios will be determined from analysis of the same aliquot from the soil sample.

\subsection{Depth Distribution}

Sample results for the upper three depth intervals shall be analyzed for the parameters in Tuble 2-1. If results indicate radioactivity concentrations that are not decreasing with increasing depth. are inconsistant or otherwise questionable. then the archived lower depth intervals shall be analyzed for the same parameters to determine the depth distribution. 



\subsection{Health and Safety Plan}

The health and safety protocols for the field activities reiated to the implementation of this field instruction are delineated in the SSHASP presented in Appendix B. The SSHASP sets forth the specific requirements and procedures that shall be followed while pertiorming operations under the field instruction. In addition. all requirements of the NV ERP Health and Safety Plan (DOE. 1994) shall be observed.

The SSHASP includes the following information:

- Protective measures. engineering and administrative

- Monitoring for site-specific contaminants. chemical and radiological

- Personal protective equipment and its use

- Site control

- Emergency communicutions

- Emergency reporting protocol

- Decontamination

- Site characterization

- Training.

All field activities shall be performed in accordance with the SSHASP. A copy of the SSHASP shall be maintained on site by the field coordinator during all field activities. All field personnel involved in these activities shall be cognizant of the SSHASP. All visitors to the work sites shall be required to abide by these procedures.

The objective of the SSHASP is the protection of workers during NV ERP activities. This shall be accomplished through compliance with DOE Orders, Occupational Safety and Heaith Adminisration regulations. the DOE/NV NVIYMP Radiological Control Manual (1992b), the VV ERP Health and Safery Plan (DOE. 1994), and the SSHASP. 



\subsection{References}

DOE. see L.S. Department of Energy.

EG\&G. see EG\&G Energy Measurements.

EG\&G Energy Measurements. 1985. An Aerial Radiological Survey of the Feed Materiats Production Center and Surrounding Area. EGG-1(1282-1084. Fernald. OH.

EPA. see U.S. Environmental Protection Agency.

IT Corporation. 1993. Operation Specific Quality Assurance Manual Management Plan. Earth City, MO.

Martin. B.W.. 1989. "Interview with Mr. Harold L. Rarrick. Albuquerque. New Mexico. March 16. 1989." History Associated Incorporated. Rockville. MD. p. 33.

NAS, see National Aíademy of Science.

National Academy of Science. 1965, The Radiochemisny of Plutonium. NAS-NS-3058. Washington. DC.

National Academy of Science. 1962. The Radiochemistry of Uranium. NAS-NS-3050. Washington. DC.

Sandia National Luboratories. 1982. 1981 Emirommental Summary. Albuquerque. VM. and Livermore. CA.

Shreve. J.D.. Department of Defense. 1965. Operation Roller Couster-Scientific Director's Summury Report. DASA-1644. Washington DC.

SNL. See Sandia National Laboratories.

U.S. Department of Energy, Nevada Operations Office. 1994. Nevada Environmental Restoration Project Health and Safery Plan. Las Vegas, NV.

U.S. Department of Energy, 1992a. Environmental Measurements Laboratory Procedures Manual. HASL-300. New York, NY.

U.S. Department of Energy, Yuccia Mountain Project Office. 1992b, NV/YMP Radiological Control Manual. Las Vegas. NV.

U.S. Environmental Protection Agency. 1992. Tust Methods for Evaluating Solid Waste. Physical Chemical Methods. SW-846. 3rd edition. Final Update I. Washington. DC. 



\section{Double Tracks \\ Field Sampling Instructions}

Prepared By

IT CORPORATION

4330 South Valley View Boulevard, Suite 114

Las Vegas, Nevada 89103

Work Performed Under Contract No.

DE-AC08-92NV10972

April 1995 



\section{Double Tracks}

Field Sampling Instruction
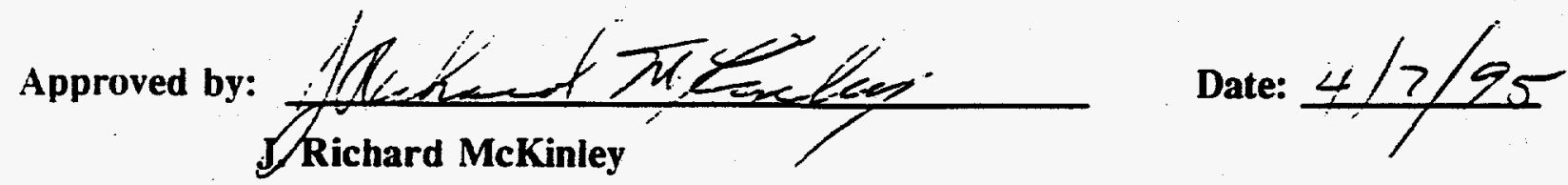

Double Tracks Project Manager

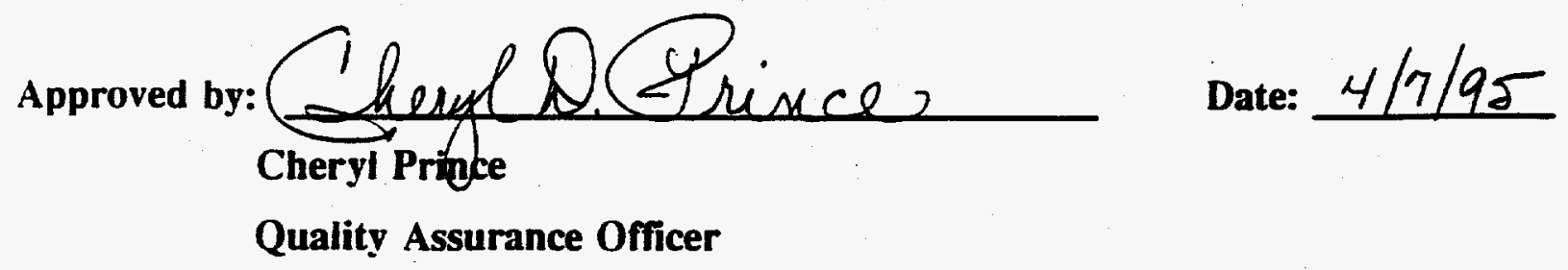





\subsection{Introduction}

This Field Sampling Instruction document is intended to fulfill the Sampling Plan requirements for the Double Tracks field effort that will be conducted the week of April 10, 1995. as well as describe the activities that will be required by the field team. The overall strategy of this field effort is not to characterize the extent of radiological contamination at the site. but rather to test radiation instrument surveying applicability, determine radiological contaminants physical properties (and how the contaminates are entrained in the soil matrix) and collection of duplicate samples for laboratory analysis. The data and results for the field activities described in this document should not be used in a risk assessment. Results from this field effort will be used to streamline and focus site characterization and possible remediation efforts. Many field activities will be conducted during this field trip, with several that are unrelated to the tasks described in this document. However. the field crews, while having different agendas and goals. will work as a team to insure that all tasks are completed in a timely manner.

\subsection{General Scope of Work}

The field effort described in this document will concentrate on surface radiological measurements and soil sampling in the upfield area. Additional field activities will be conducted by other contractors in the downfield areas and are not discussed. Field tasks to be completed include "hot spot" mining to determine the feasibility of removing identified hot spots from specific areas and depth profile measurements, to evaluate the depth that plutonium and americium have migrated. Field radiological measuring instruments that will be used during these tasks inciude the following.

- Suburban mounted sodium-iodine (NaI) detector with a approximately a 13 meter diameter field of view

- FIDLER hand held instrument 
- Tripod mounted germanium $(\mathrm{Ge})$ detector collimated to view approximately a one meter area.

- $\quad$ Tripod mounted germanium detector collimated to view approximately a 0.3 meter (one foot) area

To evaluate hot spot mining, field radiological measurements will be conducted in areas that have been previously identified by EG\&G in aerial flyovers to have an activity of between 200 to $400 \mathrm{pCi} / \mathrm{g}$. The Suburban mounted detector will be used first to measure several areas of elevated activity. Next, the walk over surveys, using a FIDLER will identify hot spots within the Suburban mounted detector's field of view and mark the hot spots with either flagging or dye. The hot spots will be physically mined (picked-up) and taken out of the detectors field of view. After the material has been removed. the area will be re-measured with the FIDLER to determine if the hot spot activity has been adequately removed. Hot spot removal will continue until approximately 80 to 90 percent of the activity from the identified hot spots has been eliminated. The suburban mounted detector will then be re-employed to measure the activity of the same area.

At other locations depth profile evaluations will be conducted after several areas of high activity have been identified. some distance from the Suburban detector areas. At selected hot spots. a tripod mounted collimated instrument will be used to collected more precise radiological measurements. After the one or 0.3 meter collimated instrument has collected a measurement, a thin layer of soil will be physically removed and additional measurements taken. with the same instrument. The removed material will be taken to an area removed from the instrument area of view. By continually removing material to greater depths, and taking field measurements it can be estimated how deep the contamination has migrated. The depth profile will also be used by EG\&G to refine their formulas for determining total activity from surface americium gamma radiation.

During this task, soil will be removed in approximately one centimeter layers. Some of the 
removed soil will be retained, placed in sample containers, with chain of custody. and transported to Las Vegas. Details of how samples are to be collected and retained. as well as field documentation are discussed in the following section.

In addition. two relatively new approaches to field measurements will be explored. The insitu measurement of alpha energy using standard radon gas detection systems has been explored at Oak Ridge National Laboratory (ORNL) Health and Science Research Division. A three person (ORNL) team will be included for part of this field effort and will have a preplanned program. There will be time. however, to work with IT to evaluate the comparative efficiency of the just acquired. newly developed. SAIC AP-2 Alpha Analyzer. This instrument will first be evaluated to determine if it can "measure" americium and plutonium using its 128 channel Multi-channel Analyzer (MCA). The first effort will be to put a thin layer of contaminated soil into the bottom of a petri dish such that the MCA can be supported by the rim of the dish and left in place for a period of time. This type of measurement can then be compared to the measurements derived from the same sample by the ORNL system.

The ORNL effort is directed toward development of a relatively inexpensive, and perhaps immediate field result, system. Obviously, if the AP-2 can approximate these results, cost and speed would both be improved. This effort will be research in nature and thus evolutionary.

Other field tasks will include surveying both previous sample locations and selected locations from this field effort. Selected soil samples will be collected at locations of elevated activity and submitted to the laboratory for isotopic analysis. These soil samples will be collected to confirm isotopic ratios of plutonium and americium. Previous laboratory results were inconclusive concerning these isotopic ratios, especially at low activity levels. By collecting a sample that is known to have elevated activity, a more precise determination of these isotopic ratio can be determined. 


\subsection{Surface Radiation Measurements}

Surface radiation measurements will be conducted by Reynolds Electrical \& Engineering Co. (REECo) and EG\&G. assisted by the IT project team. Procedures and requirement for these measurements are summarized in contractor specific procedures. ITs contribution to the field radiological measurements will consist of assisting in the selection of areas where measurements will be taken, collecting soil samples for possible laboratory analysis and assisting with the field interpretation of the data. IT will also be evaluating several soil removal techniques that will require additional surface radiation measurements to be performed by various instruments. These are discussed in greater detail in the following sections.

\subsection{Soil Sampling}

Several soil samples will be collected as part of this field effort. The sampling effort is focused primarily on field radiation measurements and method verification and not on site characterization. Because the focus of the sampling is not site characterization. some of the quality control and equipment decontamination criteria will not be as rigorous as is typically required. Variations to these procedures are discussed later in Sections 6 and 7.

The soil sampling effort can be divided into two tasks. The first task consists of an experiment to mine contaminated soils from selected areas. The second task consists of depth profile sampling that is being conducted to determine the depth plutonium and americium have been transported into the subsurface. It is anticipated that approximately 10 to 12 soil samples will be collected as part of this field effort.

\subsection{Hot Spot Mining Samples}

This phase of the field effort focuses on field instrument identified hot spots sampling. All soil samples retained as part of this effort will be contained in appropriate sample containers and sample collection and chain of custody forms properly filled out. The samples will be transported to Las Vegas where it will be determined during the following week which 
samples will be forwarded to the laboratory for analysis and which will be archived. The delay is required to allow the project teams severai days to review the field radiological measurements and other field notes and identify the appropriate samples to be submitted to the laboratory. It is anticipated that many of the samples will be archived.

During the soil mining experiment conducted in association with the Suburban and FIDLER instrument surveys, several samples (approximately five to ten) will be collected and retained. Approximately three to five samples will be passed through a Jones Splitter and three to five retained without splitting. A Jones Splitter is a device that will split the soil sample into two approximately equal volumes. After the sample has been split, it will be re-measured with the FIDLER. The activity should be approximately equal in each split sample. If this is not the case, the sample with the highest activity will be retained for possible laboratory analysis. Samples that are not split will not require re-measuring with the FIDLER.

\subsection{Depth Profile Samples}

Collection of depth profile samples will be associated with the tripod mounted collimated germanium detectors. Several methods of profile sampling will be conducted, with each requiring different sampling procedures. Approximately three to five samples will be collected during this phase of the field effort.

The general strategy of this field task is to collect field radiological measurements, remove or scrape a small layer of soil from the area of concem, and re-measure the radiological activity. This process will continue until approximately 80 to 90 percent of the activity has been removed. For soil sampling purposes, only the first layer of soil removed will be retained as a sample. It is anticipated the majority of the radiological contamination will be in this layer. If field instruments indicate that the radiological contamination is at a much greater depth, this sampling strategy will change and additional depth samples will be required.

The methods used to remove the layers of soil during this task include the following 
- Using a adhesive and a small test plate (tile). The soil will be sprayed with a adhesive and allowed to dry. The plate with exposed adhesive will than be placed on the area of concern. The soil that adheres to the plate will be set aside and another field radiological measurement taken. This process may be repeated several times to determine if the radiological contaminants are effectively removed. Field experimentation may determine that it is more feasible to remove the deeper layers with one of the following scraper techniques.

Another method to remove a small layer of soil will use a stainless steel scraper or trowel to physically scrape the layer of soil into a dust pan type device. After the layer of soil has been removed it will be set aside and another field radiological measurement taken. This process will be repeated several times to determine if the radiological contaminants are effectively removed.

- The final method that will be tested to remove the soil layer will be to use a dust broom, or "foxtail" to sweep the soil from the test area into dust pan type device. After the layer of soil has been removed it will be set aside and another field radiological measurement taken. This process will be repeated several times to determine if the radiological contaminates are effectively removed.

Several other types of scoops, shovels etc. will also be taken to the site and field tested if the first three options fail to obtain required results. This task is a "lets see what works best" type of exercise, so additional field notes should be taken to sufficiently document procedures, unanticipated problems, field instrument measurements and successes. Field notes will be prepared in accordance with SOP ITLV-0401. 


\subsection{Sample Management}

After containerizing soil samples collected as part of this field effort. each must be field screened for worker health and safety requirements in accordance with SQP ITLV-0403. A REECo Radiological Control Technician (RCT) will perform the screening. Once the RCT has issued a Green Tag and Radiological Material Clearance Sticker, the sample can be removed from the site and transported for storage. Smear samples of the sample container exterior may be performed in accordance with the REECo approved procedures. Each shipment of samples will be accompanied by a Request Analysis Request and Chain of Custody (AR/COC) form according to SQP ITLV-0402. Following receipt of the Radiological Material Clearance Sticker, samples for shipment to the off-site laboratory shall be packaged in accordance with the procedures given in SQP ITLV-(0403.

Samples submitted for laboratory analysis will be sent to the Quanterra Laboratory in St. Louis. Missouri. to the attention of Allen Field. Each shipment shall be accompanied by a AR/COC form completed according to SQP ITLV-0402.

\subsection{Laboratory Analysis}

Samples submitted to the laboratory will be analyzed for isotopic plutonium $\left({ }^{239240} \mathrm{Pu}\right.$ and $\left.{ }^{238} \mathrm{Pu}\right)$ and Americium $\left({ }^{241} \mathrm{Am}\right)$ and total uranium. Table 1 summarizes the analytical requirements.

\subsection{Quality Control Samples}

Because site characterization samples are not being collected as part of this field effort, some of the QA requirements typically followed will not be performed. In addition, only samples that are known to be contaminated will be collected so field blanks and rinsate blanks will not be required. Field duplicates will be collected at not less than 10 percent of the total number of samples collected. Soil is the only media that will be sampled during this field effort.

Special instructions will be given to the laboratory so that as a minimum, three selected 
samples will be ball milled and split into two equal volumes at the laboratory prior to analysis of both fractions. A memorandum will be prepared that will instruct the laboratory on what is required. This memorandum will be modified as required based on field observations and experience and attached to the AR/COC. This information will also be verbally communicated to laboratory prior to shipment of the samples.

\subsection{Equipment Decontamination}

Because site characterization samples are not being collected as part of this field effort some equipment decontamination requirements typically followed during an investigation of this type will not be performed. Only samples that are known to be significantly radiologically contaminated (no organic compounds), will be collected. so solvent rinses will not be required. Disposable sampling equipment will not require decontamination. Reusable sampling equipment decontamination will consist of the following:

- Scrape or brush off residual soil

- Wash with a laboratory grade detergent and potable water

- Potable water rinse

- Final deionized water rinse

- Air dry.

After decontamination, sampling equipment will be stored in a manner to prevent recontamination, such as wrapping in plastic. Only equipment that has the potential of coming in direct contact with the soil sample will require decontamination between uses. For example, equipment used to mine hot spots that are not sampled do not have to be decontaminated between hot spot locations. 
Table 1

Summary of Laboratory Analytical Requirements

\begin{tabular}{|c|c|c|c|c|}
\hline Isotope/Analyte & CAS Number & $\begin{array}{l}\text { Analytical } \\
\text { Method }\end{array}$ & Detection Limit & $\begin{array}{r}\text { Sample } \\
\text { Container }\end{array}$ \\
\hline $\mathrm{Pu}^{239 / 240}$ & $\begin{array}{l}15117-48-3 \\
14119-33-6\end{array}$ & NAS-NS-3058 & $0.04(\mathrm{pCi} / \mathrm{g})$ & $\begin{array}{l}250 \mathrm{ml} \\
\text { Glass }\end{array}$ \\
\hline $\mathrm{Pu}^{238}$ & $14111-32-5$ & NAS-NS-3058 & $0.04(\mathrm{pCi} / \mathrm{g})$ & $\begin{array}{l}250 \mathrm{ml} \\
\text { Glass }\end{array}$ \\
\hline $\mathrm{Am}^{2+1}$ & $14596-10-2$ & NAS-NS-3006 & $0.01(\mathrm{pCi} / \mathrm{g})$ & $\begin{array}{l}250 \mathrm{ml} \\
\text { Glass }\end{array}$ \\
\hline Total Uranium & $\overline{N A}$ & ASTM 5174-91 & $0.05(\mu \mathrm{g} / \mathrm{g}, \mathrm{ppm})$ & $\begin{array}{l}250 \mathrm{ml} \\
\text { Glass }\end{array}$ \\
\hline
\end{tabular}





\section{Scope of Work for Double Tracks Radiological Surveying \\ June 5 to 9, 1995}

\subsection{Introduction}

This document is intended to describe the strategy and goals for the Double Tracks field effort that is to be conducted the week of June 5, 1995. The strategy of this field effort is to determine the extent of radiological contamination to a confidence level so corrective actions can be proposed. Based on previous field survey results, the types of radiological survey instruments, detectors, proposed have proven to preform to an acceptable level to accomplish the goal. Results from this field effort will be presented in the Implementation Plan and Corrective Action Plan. The field results will be used to select appropriate remedial technologies which will in turn prescribe remediation budgets and schedule. The data and results from this field investigation are not for the purposes of a baseline risk assessment.

\subsection{General Scope of Work}

The field efforts will focus on several radiological surveys that will utilize different types of detectors. The detectors that will be used include the following.

- FIDLER detectors, Sodium Iodine (NaI) mounted on an all terrain vehicle (ATV) bumper.

A Suburban with a boom mounted Germanium (GE) detector.

$\mathrm{Nal}$ detectors (from the EG\&G helicopter) mounted on the bumper of a Suburban.

- A scintillation detector mounted on the bumper of a Jeep Cherokee.

All the above instruments are EG\&G's, except the scintillation detector mounted on a Jeep Cherokee, which is an IT instrument. 
Other field tasks to be conducted, in conjunction with the radiological surveys, include "hot spot" mining near ground zero (GZ), in the mound area, and land surveying. In addition, background will be surveyed with detectors used during this field effort. Because of the anticipated vehicle traffic inside the exclusion zone, one of the first tasks to be undertaken will be to pick up debris from inside the exclusion zone. This debris includes the many sample location stakes and markers, as well as the inner fence. All warning and safety markers will not be disturbed The debris will be staged in a remote area of the exclusion zone until disposal requirements are determined. Unexploded ordinances (UXO) will be picked-up by DOD personnel, if possible. Otherwise. the UXO debris will be avoided.

\subsection{Radiological Surveys}

\section{FIDLER detectors, mounted on an all terrain vehicle (ATV)}

To quickly locate hot spots in the exclusion zone, three FIDLER detectors have been mounted on an ATV. This ATV will be driven systematically across the site on approximately two meters (seven-feet) center traverses. When a hot spot is detected, a marker will be placed in its general vicinity. Once the dust has settled in the vicinity of the marker, the area will be surveyed with hand held FIDLER detectors to locate and identify the hot spot material. If the hot spot represents a piece or chunk, the material will be taken to a central location, inside the exclusion zone until disposal requirements are determined Based on the historical records and previous field efforts, many of the hot spots located within two to three hundred feet of GZ represented large pieces of unknown material. The unknown material may represent device encasement material, part of the steel plate or remnants of plutonium ( $\mathrm{Pu}$ ) and/or depleted uranium (DU).

To better understand and estimate the activity present in the collected pieces or chunks of material, several pieces will be weighted and counted in the field. The selected pieces will be weighted using a field balance, with the accuracy of approximately 0.01 grams, and counted with a Nal collimated detector. After taking these measurements, the piece will be labeled and containerized with the other pieces. These results will be used to estimate total activity so disposal options and requirements can be evaluated. 


\section{Suburban boom mounted Ge Detector}

The Ge detector mounted on the Suburban has been proven to be an accurate detector of radiological contamination at the Double Tracks site and will supply the most reliable measurements. The detector when fully extended on the boom will see approximately a 13-meter diameter area. The only drawback of this detector is that it is slightly time consuming. It is anticipated that 25 to 30 measurements can be completed in the one week field effort. This represents approximately 5 percent of the entire exclusion zone's area, including GZ.

Previous ground survey results have ascertained that some of the anomalies in the helicopter flyever survey represent hot spots. By removing the hot spots before surveying the exclusion zone with the Suburban $\mathrm{Ge}$ detector, many of these anomalous areas should no longer exist. The Suburban data will be compared and contrasted with the older helicopter flyover survey results. Note that the Suburban survey will be on a much finer grid with the detector much closer to the ground.

\section{Other Detector Surveys}

Data from the scintillation detector mounted on a Jeep Cherokee (IT) and NaI detectors mounted on the Suburban (EG\&G) will be used in conjunction with the Suburban Ge detector results to determine the nature and extent of contamination. During the initial scoping of this field effort, the intent was to have the $\mathrm{NaI}$ detectors, used in helicopter flyover surveys, mounted on a suburban bumper. The suburban would than systematically survey the exclusion zone at a much finer scale, and with the detectors much closer to the ground. Results from this survey will be compared with the Suburban Ge detector, previous helicopter survey results and FIDLER results. Combining these four survey results will accurately determine the extent of contamination.

The scintillation detector mounted on the Jeep Cherokee was decided upon as a cross check of the other radiological survey results. This scintillation detector was not in the original scope of work; however, it became available and was decided to be utilized as a cross-check. This scintillation was being used in southern California and will be mobilized to the Double Tracks site 
at only minor costs. This detector system has a positioning system different from the other detectors so the locations of the hot spots and anomalous areas can be independently located. It is anticipated that the scintillation detector survey will only require two days to complete.

\subsection{Ground Zero (Mound) Characterization}

To characterize the extent of contamination in the vicinity of GZ, the ATV, with FIDLERS, will identify areas that are grossly contaminated from areas that are lightly contaminated. Historical records indicate that the contaminated soil in the immediate area around GZ was scraped into a mound at approximately $\mathrm{GZ}$ shortly after detonation. Other activities in the vicinity of GZ may also have reworked some of the material. These activities resulted in there being several relatively clean areas mixed in with more contaminated areas. The scintillation and FIDLER detectors will be used to determine the relative horizontal extent of radiological contamination in this localized area.

In the mound area, the vertical extent of contamination is not accurately known. To determine the vertical extent of contamination, several boreholes (five to ten) will be advanced.

Characteristic soil samples will be collected and field screened. The intent of this sampling is to determine the relative depth of contamination, not its magnitude. The rational for only field screening the soil are that these samples will only be used to estimate the volume of contaminated material present, and generally characterize its physical property (e.g., mostly sand, silt, clay etc., or many large pieces, (i.e., chucks of concrete)).

The boreholes will be first attempted with hand bucket augers, and if this does not adequately penetrate the material, a power auger will be utilized. Also during the soil boring activities, the field crew will attempt to determine if the concrete pad, historically known to be located at $G Z$ is still present or has been removed from the site. If the concrete pad is present, an attempt will be made to determine if it has been broken-up or is still in one piece. If the concrete pad is encountered, no attempt will be made to auger or core through the concrete to determine if contaminated soil is beneath it. In addition, it is known that oil was spread on the ground in the 
vicinity of GZ, for dust suppression. An attempt will also be made to locate this horizon as marking the bottom of the contaminated zone. After completed, all the boreholes will be backfilled with the removed material.

In areas away from the mound, previous investigations have determined, with good certainty, that the contamination present is limited to the upper few centimeters (inches) of soil. 



\section{Double Tracks}

\section{Field Sampling Instructions}

Prepared By

IT CORPORATION

4330 South Valley View Boulevard, Suite 114

Las Vegas, Nevada 89103

Work Performed Under Contract No.

DE-AC08-92NV10972

July 1995 



\section{Double Tracks}

\section{Field Sampling Instruction}
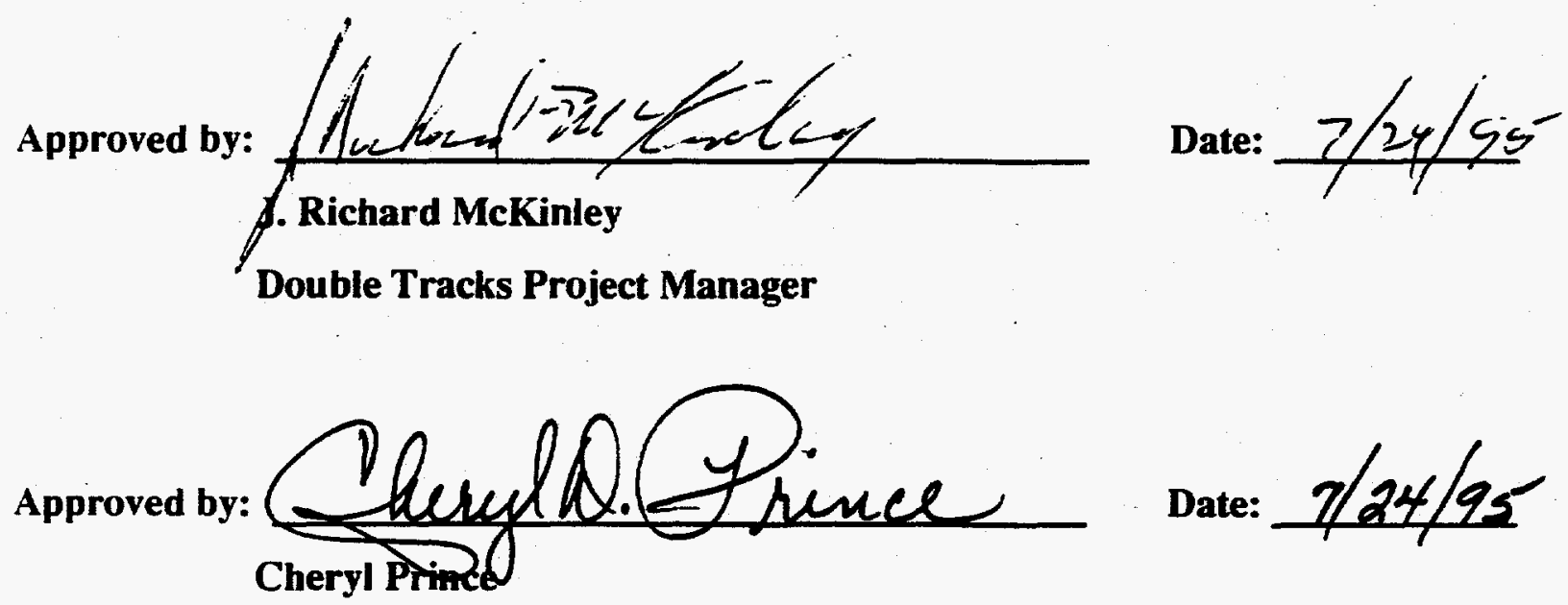

Quality Assurance Officer 



\subsection{Introduction}

This Field Sampling Instruction document is intended to fulfill the Sampling Plan requirements for the Double Tracks field effort that will be conducted on July 25, 1995 as well as describe the activities that will be required by the field team. The overall strategy of this field effort is to go inside the exclusion zone at the Double Tracks site and collect contaminated soil at previously identified locations. The soil will then be sent to the IT Treatability Laboratory in Knoxville, Tennessee. Only one task will be conducted during this field effort and it is anticipated that the field crew can complete the required activities in one day. This sampling effort has been expedited because of limited access to the site.

A separate Health and Safety Plan associated with these field activities has been approved.

\subsection{General Scope of Work}

To more accurately determine the feasibility of conducting volume reduction, through particle separation, bench scale tests are scheduled to be conducted. These laboratory tests will require that contaminated soil from the Double Tracks site be collected. The intent of this sampling instruction is to describe the procedures that will be followed during the one-day field effort. The data and results from the field activities described in this document will be included in the site characterization report.

\subsection{Soil Sampling}

The general strategy of the soil sampling effort will be collect characteristic soil from areas known to be contaminated with radiological constituents. It is anticipated that 201 -liter samples of soil will be collected from 10 sites, two samples per site, in order to adequately test the soil. The samples will be collected starting approximately 200 feet south of the Ground Zero mound, and than at 100 foot intervals at centers of the contaminant plume (See Attached Figure). Samples will be collected from south to north, least contaminated to most contaminated. Sample sites will be located using a surveying measuring wheel and measuring the distances from ground zero and the perimeter fence. 
After the sampling site has been located, approximately four liters of soil will be excavated to a depth of approximately seven centimeters (three inches). Two liters of soil will than be collected and passed through a Jones Splitter. A Jones Splitter is a device that will split the soil sample into two approximately equal volumes. After this sample has been split, one half will be discarded and the other half placed in a clean 5-gallon plastic bucket. Another two liters will than be collected and also passed through the splitter. One split of this sample will be discarded and the other split combined with the soil in the 5-gallon bucket. The soil in the 5-gallon bucket will than be passed through the splitter a final time and each split placed in labeled sample bottles (See Attached Diagram). The sample bottles will be 1-liter, wide mouth plastic.

All samples will be accompanied by a properly completed chain of custody (COC). The intent of this sample splitting is to have one sample sent to the Knoxville Treatability Laboratory and the other given to the Desert Research Institute (DRI) from each sample location. To expedite the chain of custody procedures, as the samples are being collected, a separate COC will be filled out for the IT samples and another one for the DRI samples. This will avoid preparing another $\mathrm{COC}$ when the samples are released to the respective laboratory. The Sampling Collection Logs and Field Activity Daily Logs will cross-reference the respective samples with the COCs.

During sampling activities, the soil will be periodically field screened for radiological constituents, hot particles. If hot particles are detected in any spilt sample, the sampling crew will place the soil back in the excavation, move several feet from the initial sampling location and collect another sample. The intent is not to include hot particles in the sample volume.

\subsection{Sample Management}

After the soil sample has been collected, the exterior of the sample containers will be screened by the onsite Radiological Control Technician (RCT). Once the RCT has determined that there is no external contamination, they will be packaged into a cooler for transport back to Las 
Vegas. The exterior of the cooler will also be screened before leaving the site. Each cooler will have an accompanying Chain of Custody (COC) form according to SQP ITLV-0402. In Las Vegas a sample from each location will be given to DRI for testing and the other sample repackaged in accordance with the procedures specified in SQP ITLV-0403 and shipped from the IT Las Vegas office to the Knoxville laboratory. Because only soil is being collected for treatability studies, the sample cooler will not require absorbent material or ice. All sample containers will be double bagged to insure no soil is accidentally released during transportation.

\subsection{Quality Control Samples}

Because site characterization samples are not being collected as part of this field effort, typical Quality Control/Quality Assurance (QA/QC) are not required. Soil is being collected for treatability studies so field QA/QC samples are not required.

\subsection{Equipment Decontamination}

Because site characterization samples are not being collected as part of this field effort, many equipment decontamination requirements typically followed during an investigation will not be performed. Only samples that are known to be radiologically contaminated (no organic compounds) will be collected, so solvent rinses will not be required. Disposable sampling equipment will not require decontamination. Reusable sampling equipment decontamination will consist scraping or brushing off residual soil and field screening the equipment for contamination. If contamination is not present, the equipment can be reused at the next sampling location. If gross contamination remains on the equipment the following procedure will be followed.

- Wash with a laboratory grade detergent and potable water

- $\quad$ Rinse with water

After decontamination, sampling equipment will be stored in a manner to prevent 
recontamination, such as wrapping in plastic. Only equipment that has the potential of coming in direct contact with the soil sample will require decontamination between uses.

\subsection{Laboratory Requirements}

Treatability testing instructions and requirements will be given to the laboratory via a memorandum that will accompany the samples. This memorandum may be modified as required based on field observations or as directed by the laboratory as the treatability tests proceed. All changes to the treatability testing requirements will be properly documented in the project files. 


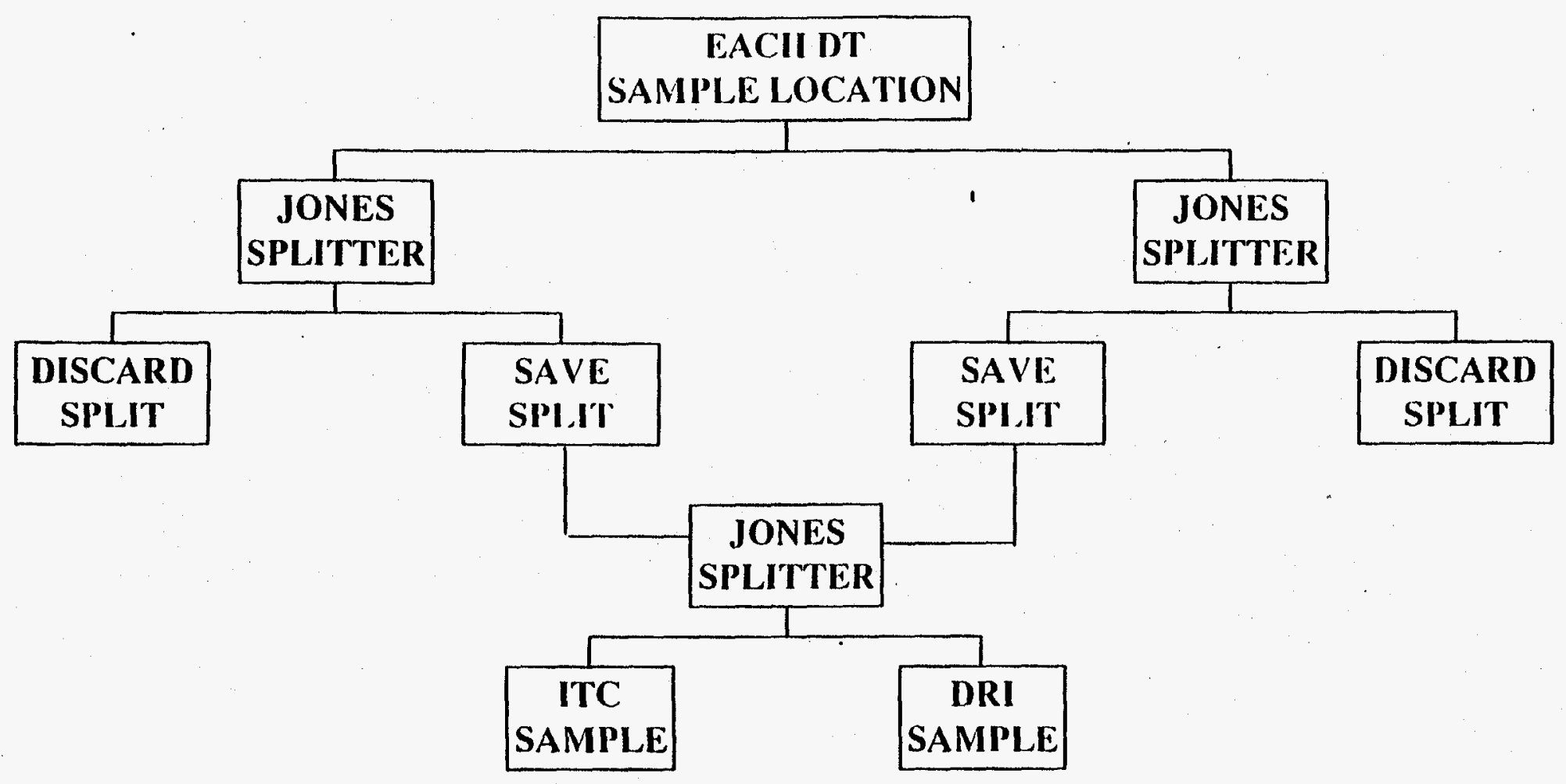





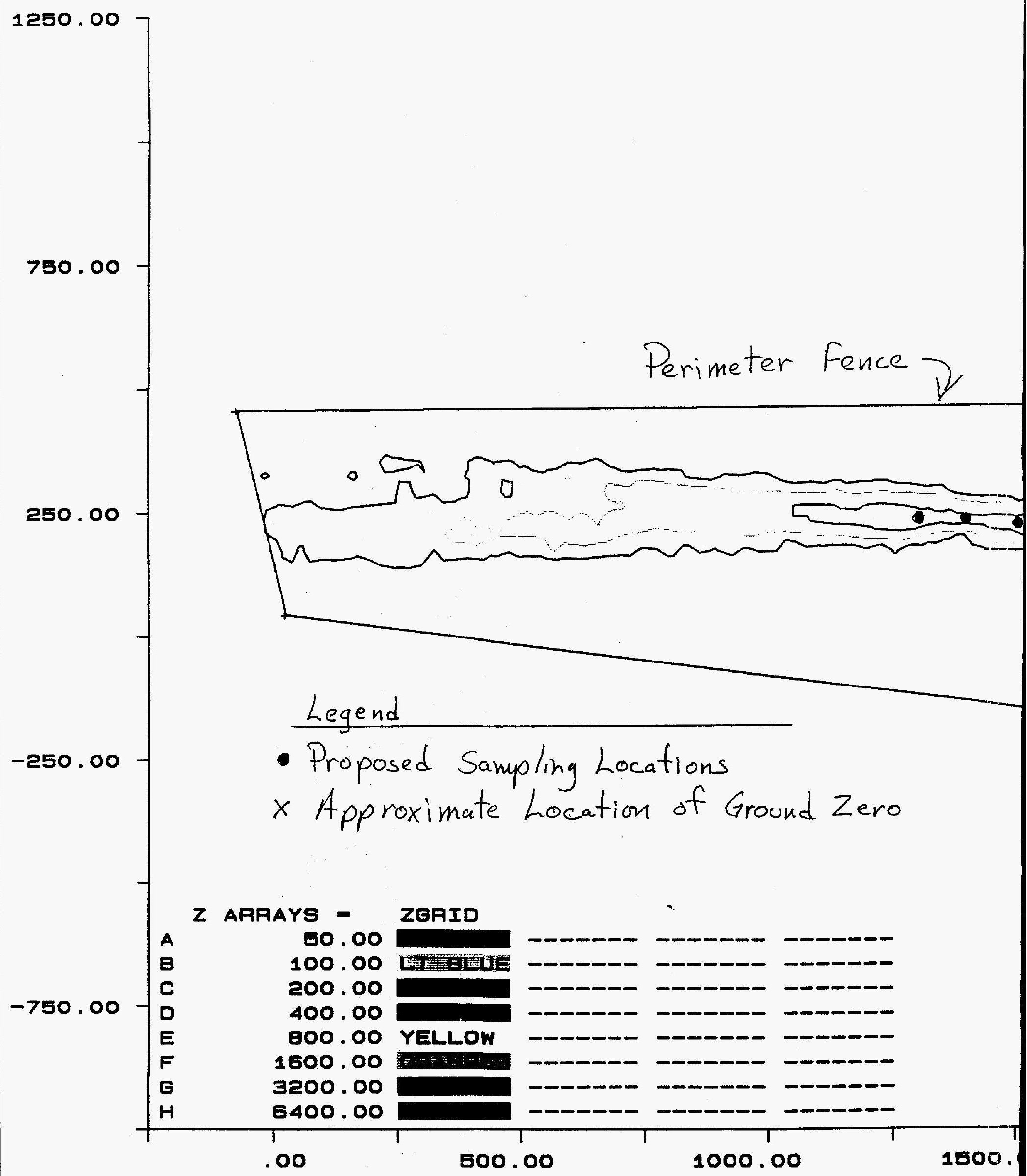

TTR, DOUBLETRACK, KIWI, 30 FOOT AVE COMPUTED AT 30 FoO Frame: oe $06 / 23 / 98$ 13: 00: 48 surveve TJHTTRIN 199E 
Appendix B

\section{EG\&G Remote-Sensing Mission Plans}




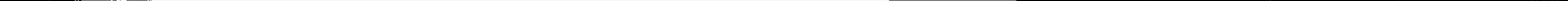




\section{REMOTE SENSING MISSION PLAN \\ IN SITU RADIATION SURVEY OF DOUBLE TRACKS TEST SITE}

Nellis AF Bombing and Gunnery Range, Nevada

MISSION PLAN APPROVAL

FUNCTION

Mission Manager

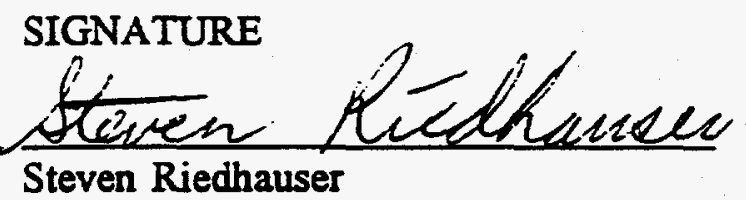

DATE

Steven Riedhauser

Work Package Manager

Safety Officer

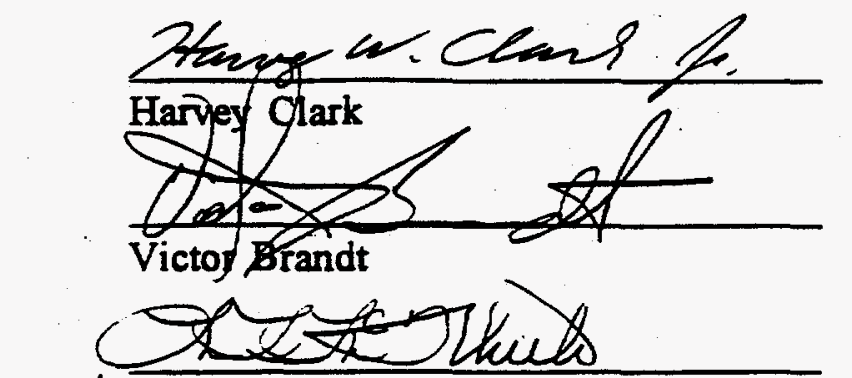

8 March 95

Director, Remote Sensing
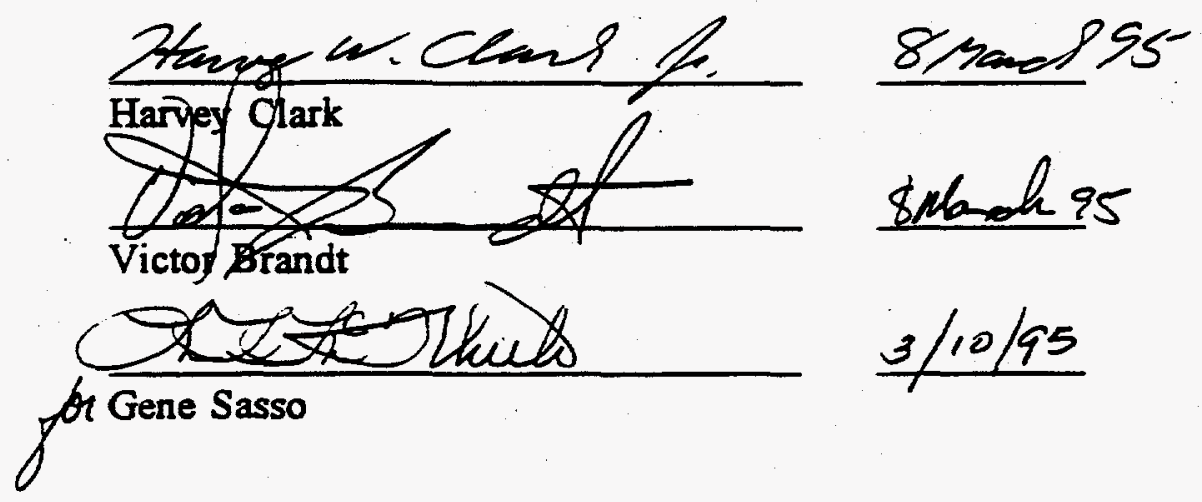



\section{Purpose/Reason for this Mission}

The Double Tracks Test Site was previously surveyed from an aerial platform in February 1977 and December 1993. The Department of Energy requested that IT Corporation conduct a series of tests to map the area which must be cleaned up prior to release of the site back to the Air Force. IT has asked REECo and us to help in a preliminary characterization by performing a series of experiments using our high-purity germanium ( $\mathrm{HPGe}$ ) detectors in concert with REECo's FIDLER system and IT's soil sampling. The survey is scheduled during the week of April 3-7, 1995 using the Suburban and two tripod HPGe detector systems of the Radiation Science Section.

\section{Mission Objectives}

The objectives of this mission are to gather in situ radiological data at a series of locations within the Double Tracks exciusion zone to compare with data collected by. systems fielded by IT and REECo. A series of four experiments are planned as described briefly below and in more detail in the letter: "Data Collection Plans for Double Tracks" (RSS-95-033).

(1) The first experiment is a mini-survey over a small region of the fenced-area at Double Tracks. This area will be approximately 90 meters by 90 meters in size and 200-300 meters south of GZ. The mini-survey will involve all of the different organizations and detection systems at one time or another and will probably last the entire week.

The coilimated Suburban system will make measurements on a 15 -meter grid to guarantee $100 \%$ coverage of the ground. For $1 \%$ statistical error, we need a counting time of 350 seconds. We should easily satisfy the statistical requirements using a 500second (8.3-minute) live time counting period. The 90 - by 90 -meter grid, sampled every 15 meters (for a total of 49 measurements) with 20 minutes per measure-andmove cycle, will require 16.3 hours (about 2 days) to complete.

The coilimated tripod HPGe detectors have a field-of-view of about 2 meters radius and will therefore need to make measurements every 2.5 meters over an area of roughly 15 meters by 15 meters. For $1 \%$ statistical error, we need a counting time of 210 seconds. We should easily satisfy the statistical requirements using a 300-second (5-minute) live time counting period. The 15 - by 15 -meter grid, sampled every 2.5 meters (for a total of 49 measurements) with 15 minutes per sample-and-move cycle, will require 12.25 hours to complete. This is a little more than one day of work for one tripod system to survey one Suburban footprint. The second tripod system should be used to survey another Suburban footprint.

Once these two systems have made their measurements on the grid, the FIDLER-based USRADS system will move through the grid, making their own measurements. Also, a set of electret ionization chambers will be arranged by personnel from ORNL. These 
detectors are piaced on the ground in a pattern of 9 locations to cover a single Suburban footprint. Three detectors would be fielded at each location for a total of 27 detectors. Finally, personnel from IT (and REECo?) will collect soil samples for analysis of the Pu/Am ratio and soil activity. It is expected that this procedure will greatly disturb the surrounding soil and therefore the digging would best be performed after all of the other measurements are completed.

(2) This experiment will use a collimated tripod system placed as near to GZ as the crew deems reasonable. The purpose is to gather data with sufficient statistics to determine an accurate $\mathrm{Pu} / \mathrm{Am}$ ratio. A 1-2 hour measurement does not seem unreasonable. Two independent measurements seem advisable (either the same tripod at two different locations, or both tripods in roughly the same location). To minimize exposure, the personnel will vacate the hot area after setting up the tripod system and not return until the measurement is completed.

(3) This experiment will use a highly-collimated tripod-mounted HPGe detector to measure repeatedly an approximately 1 -foot diameter patch of ground. After each measurement, a layer of soil will be removed from the field-of-view of the detector and another measurement made. The purpose of this experiment is to provide an alternative method of measuring the americium distribution versus depth in the soil. The thickness of the soil layers will depend on the type of material, but will probably vary between $1-2 \mathrm{~cm}$.

Assuming counting periods of 600 seconds ( 10 minutes), another 10 minutes to dig the next layer of ground out of the detector's field-of-view, and taking data at a total of twelve layers requires 4 hours. Repeating this experiment at a second location brings the total time up to about 8 hours.

(4) This experiment will use the Suburban to measure the count rate in two undisturbed locations inside the fence, one "lower" activity and one "higher" activity area. The purpose behind these measurements is to provide some data on the area's radiation uniformity. The measurements will be made at different heights above the ground (different size fields-of-view) centered above the same spot on the ground. This will duplicate to some extent the data from the first experiment, but will be looking at the different size areas using the same detector rather than different detectors.

\section{Acquisition \& Logistics Plan}

The survey crew consists of five people with two alternates available for last-minute substitution. The crew will travel to the survey site on the moming of Monday, 3 April, set up the hot line and monitoring facilities in the afternoon, collect data for the various experiments all day Tuesday through Friday moming, and then pack up and travel back to Las Vegas Friday afternoon. 
A general description of the day-to-day activities is presented in the table below. The table shows all of the activity by EG\&G personnel. Activities by other organizations are not shown in this schedule.

\begin{tabular}{|c|c|}
\hline Participant & Activity \\
\hline 13-29 March & Time window for Suburban and tripod detector calibration tests \\
\hline 30-31 March & Pack equipment into van \\
\hline Monday, 3 April & $\begin{array}{l}\text { Travel to Double Tracks in moming; } \\
\text { Get Range access and set up operations in afternoon; } \\
\text { Check operation of detectors }\end{array}$ \\
\hline \multicolumn{2}{|l|}{ Tuesday, 4 April } \\
\hline EG\&G Suburban & Lay out grid if necessary; Begin measurements experiment \#1 \\
\hline EG\&G Tripod \#1 & Lay out grid if necessary; Begin measurements experiment \#l \\
\hline EG\&G Tripod \#2 & Lay out grid if necessary; Begin measurements experiment \#1 \\
\hline \multicolumn{2}{|l|}{ Wednesday, 5 April } \\
\hline EG\&G Suburban & Complete measurements experiment \#1 \\
\hline EG\&G Tripod \#1 & Complete measurements experiment \#1 \\
\hline EG\&G Tripod \#2 & Complete measurements experiment \#1 \\
\hline \multicolumn{2}{|l|}{ Thursday, 6 April } \\
\hline EG\&G Suburban & Perform experiment \#4 \\
\hline EG\&G Tripod \#1 & Perform experiment \#3 \\
\hline EG\&G Tripod \#2 & Perform experiment \#2 \\
\hline \multicolumn{2}{|l|}{ Friday, 7 April } \\
\hline EG\&G Suburban & In morning, finish any work from previous days \\
\hline EG\&G Tripod \#1 & In morning, finish any work from previous days \\
\hline EG\&G Tripod \#2 & In moming, finish any work from previous days \\
\hline All & Return to Las Vegas in afternoon \\
\hline
\end{tabular}

\section{Site Characteristics}

The survey is not planned to cover the whole Double Tracks area. Instead, the intent is to perform a series of tests of our equipment versus REECo's and IT's equipment and techniques 
to correlate the different data sets. The Double Tracks site is situated on an arid plain on the Nellis Air Force Bombing and Gunnery Range (NAFR). Access is through the Tonopah Test Range (TTR) and the crew will be staying in the dormatories on base.

The contacts identified so far are listed in the following table.

Contacts

\begin{tabular}{lcc}
\hline \multicolumn{1}{c}{ Name } & Organization & Telephone \# \\
\hline Craig Lyons & REECo Health Physics Dept. & (702)295-0781 \\
Laura Tryboski & IT Corp. & $(702) 794-1712$ \\
J. R. McKinley & IT Corp. & $(702) 794-1703$ \\
Monica Sanchez & DOE/ER & $(702) 295-0160$ \\
\hline \hline
\end{tabular}

\section{Risk Documents}

The ground-based operations associated with this survey have been addressed in several documents. The overall Health and Safety Plan (HASP) for work by the different organizations at Double Tracks is currently being created by REECo and IT Corporation. In addition, REECo and IT will prepare a Radiological Work Permit (RWP) for the work to be performed at Double Tracks. An assessment of the risks involved with the HPGe detector in situ measurements routinely conducted by EG\&G is presented in the "Risk Assessment for Radiation Science Section" document (August 31, 1994).

All EG\&G participants in the survey have attended the 40-hour OSHA 1910.120 training for Hazardous Waste Sites and have been fitted for respirators. The use of respirators is only expected if the survey area is very dry and the activity in the area raises appreciable amounts of dust into the air. All participants have attended the Radiological Worker II class. (One alternate technician only has Rad. Worker I, but the Health Physicist in charge has said there should be no problem if he needs to replace one of the scheduled technicians since the tech will be in a group under the direct supervision of other Rad. Worker II personnel.) Explosive Ordinance (EOD) Training will be conducted by Nellis AF personnel and will be held sometime during the last two weeks of March. 


\section{Cost Estimate}

The table below summaries the costs for this survey. The preparation costs only include those charges since 12 February. (The excluded costs are principally the costs of five people attending the OSHA 1910.120 training.)

\begin{tabular}{|c|c|c|c|c|}
\hline Item & $\begin{array}{l}\text { Preparation } \\
\text { Costs }\end{array}$ & Field Costs & $\begin{array}{l}\text { Analysis and } \\
\text { Report Costs }\end{array}$ & Totals \\
\hline Labor & $\$ 20 \mathrm{~K}$ & $\$ 20 \mathrm{~K}$ & $\$ 11 \mathrm{~K}$ & $\$ 51 K$ \\
\hline Travel & SOK & $\$ 2 \mathrm{~K}$ & SOK & $\$ 2 \mathrm{~K}$ \\
\hline Aircraft & SOK & SOK & SOK & \$OK \\
\hline$M \& S$ & SOK & \$1K & SOK & $\$ 1 K$ \\
\hline Totals & $\$ 20 \mathrm{~K}$ & $\$ 23 \mathrm{~K}$ & $\$ 11 \mathrm{~K}$ & \$54K \\
\hline
\end{tabular}

The cost of each "down day" in the field (days when no useful survey work can be done due to inclement weather or other problems) is: $\$ 4 \mathrm{~K}$

The job number for the survey is: S3F4A100

\section{Deliverables/Reports and Deadlines}

The Double Tracks in situ gamma measurements will collect data on the americium concentration at the site. EG\&G will write a brief report outlining its procedures and presenting plots of its data in the gridded areas. Tables of the data from the other experiments conducted by EG\&G will also be included. The presentation of the data from the various organizations will need to be done by project organizers, either IT Corp. or DOE.

The present schedule and plan specifies that preliminary results will be given to the project organizers when we leave Double Tracks at the end of the survey. A more-polished letter report (after completing our in-house scientific review and passing through our Reports Section) will be ready for customer review five months later. The final version of the report will be ready one to two months after the customer review is complete. 


\section{Attachment 1}

\section{Operations Safety Guidelines}

1. The Mission Manager shall ensure that the mission is safely conducted and ensures that crew members are familiar with the procedures outlined in Manual 32: "Safety", pertinent to mission operations.

2. The Mission Manager shall appoint a Safety Coordinator from the survey crew if an RSL safety staff member is not available.

NOTE: Appointment of a Safety Coordinator from the RSL safety staff is an Operations Manager's decision.

3. The Mission Manager and Safety Coordinator will review the mission plan, pertinent policies and procedures, and establish general safety coordination for mission conduct in the following categories:

a. In-house preparation (in conjunction with the RSL safety officer).

(1) System characterization.

(2) Packing and loading.

(3) Deployment.

b. Field Operations in addition to the above items:

(1) Site-specific safety requirements and FBO requirements.

(2) Non-operational safety precautions.

4. The Safety Coordinator shall monitor safety practices from the inception of mission operations through mission completion and system restoration to operational status.

NOTE: The pilot(s) will be primarily responsible for implementing guidelines related to aircraft and flight safety; however, the safety coordinator shall monitor aircraft operations and assist with handling safety concerns whenever practical.

5. The Safety Coordinator shall conduct general safety briefings in conjunction with general briefings by the Mission Manager or other briefings where safety concerns are deemed necessary. 
6. The pilots shall advise the Mission Manager and the Safety Coordinator on mission safety concerns relative to aircraft and flight operations.

7. During the mission, the mission safety coordinator shall:

a. Monitor mission tasks for safety hazards and unsafe acts.

b. Act as focal point for reporting and resolving safety problems.

c. Provide a daily safety status report to the Mission Manager for inclusion into the daily mission status report.

8. The pilot shail monitor all aspects of air crew, aircraft and associated support equipment safety.

a. Flight safety briefings will be conducted prior to any mission flights and as outlined in the appropriate flight safety regulation during flights.

b. The pilot and mechanic shall collectively monitor aircraft maintenance safety.

c. The command pilot for the mission shall submit a general flight safety report to the Mission Manager and Safety Coordinator to be included in the Mission Manager's general daily status report.

d. The pilot will continuously monitor the area weather conditions for foul weather indications so that the Mission Manager can adjust flight schedules accordingly.

9. Crew members shall:

a. Perform tasks safely with particular attention given to but not limited to: driving, lifting, hauling, carrying, climbing, and installing equipment. In particular, care will be exercised when performing any of these tasks in an unfamiliar environment.

b. Wear appropriate safety gear as required by the task or circumstance.

c. Monitor the work area(s) for any safety act or hazard that may affect coworkers.

d. Report any unsafe conditions or acts to the Safety Coordinator or Mission Manager. 
Attachment. 2

Survey Parameters

Mission Name: $\quad$ Double Tracks In Situ Survey

Location:

Nellis Air Force Bombing and Gunnery Range, Nevada

Base of Operation: Nellis Air Force Bombing and Gunnery Range

Survey type: In Situ Gamma Radiation

Aircraft: none

Nominal elevation: 1450 to $1520 \mathrm{~m}(4800$ to $5000 \mathrm{ft}) \mathrm{MSL}$.

Survey Dimensions: not applicable

Length (approx.):

Width (approx.):

Survey Altitude: not applicable

Line Spacing: not applicable

Line Direction: not applicable

Aircraft Speed: not applicable

Number of lines: not applicable

Total line length: not applicable

Flight time: not applicable

Total survey days: 5

Navigation System: not applicable

Detector Arrays: Suburban vehicle equipped with collimated HPGe detector on extendable mast

Two tripod systems with collimated HPGe detectors at 1-meter above ground level 


\section{REMOTE SENSING MISSION PLAN}

\section{SECOND IN SITU RADIATION SURVEY OF DOUBLE TRACKS TEST SITE}

Nellis AF Bombing and Gunnery Range, Nevada

MISSION PLAN APPROVAL

FUNCTION

Mission Manager

Work Package Manager

Safety Officer

Director, Remote Sensing

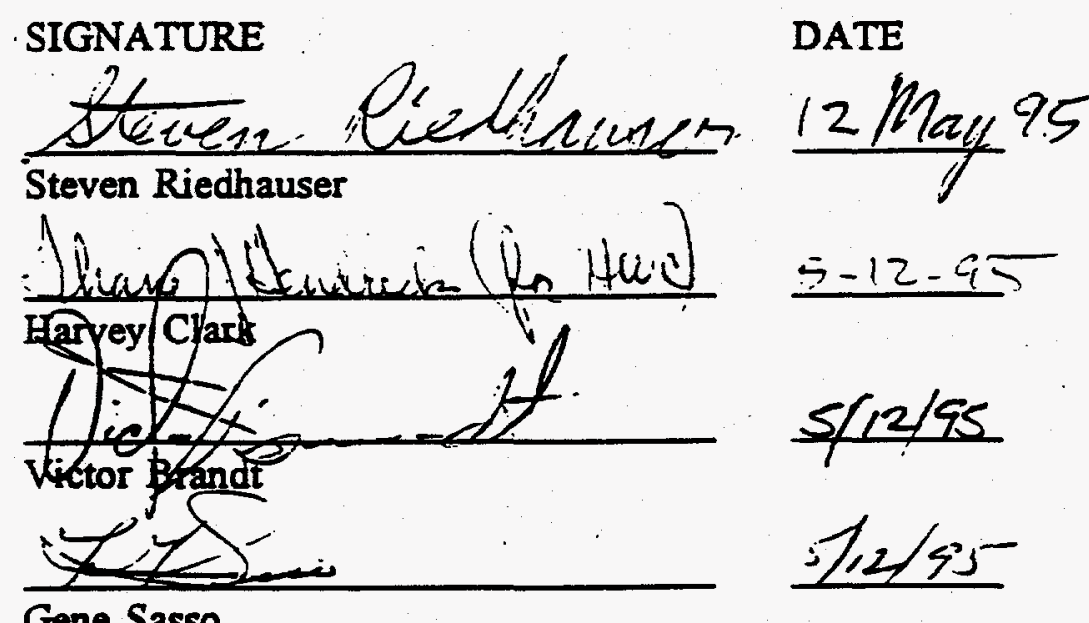





\section{Puppose/Reason for this Mission}

In eariy April, a team from EG\&G made a trip to Double Tracks to conduct field tests of several characterization techniques. This survey is a continuation (and expansion of data collection) of that previous survey. It will constitute a preliminary characterization of the site according to the overall site decommissioning plan.

The survey is scheduled for June 5-9, 1995 using a ground vehicle equipped with several NaI pods and a REDAR IV system (a new platform being developed by Thane Hendricks), an allterrain vehicle (ATV) with three FIDLER detectors (a new platform being developed by John Tipton), the Radiation Science Section's Suburban vehicle with an HPGe detector mounted on the end of a telescoping mast, and a tripod-mounted HPGe detector system.

\section{Mission Objectives}

The objectives of this mission are to gather in situ radiological data at a series of locations within the Double Tracks exclusion zone. A series of three major processes are planned as described briefly below.

(1) This process uses the ATV with three FIDLER detectors. Each detector will be collimated to view a circular spot on the ground about 24 " in diameter. With a little overiap between the fields-of-view, this will yieid an approximately 5-foot wide path as the ATV travels. The ATV will travel back and forth within the fenced area and locate areas likely to contain chunks of radioactive material such as those we saw on the last trip. This particular activity will probably not last more than a day or two. After the areas are identified, personnel with handheld FIDLERs will locate the hot particles and collect them into containers. This "mining" activity will probably occupy IT and/or REECo personnel most of the rest of the week.

(2) This process will use a specially-modified Suburban vehicle with three pods of NaI detectors mounted from the rear bumper. The signals from the detectors and from a John Chance differential GPS antenna are fed into a REDAR IV system. This system will operate in exactly the same way as our aerial systems; however, it will have increased spatial resolution and increased sensitivity. The array of six $2-x 4-x 16-$ inch $\mathrm{NaI}$ detectors at 2.5-foot altitude produces a footprint of about 3 meters (10 feet) versus a footprint of about 100 meters ( 300 feet) for the aerial system of eight 2- $x$ 4$\times$ 16-inch $\mathrm{NaI}$ detectors at 150-foot altitude. Calculations of the actual mimimum detectable activity will be performed later. The John Chance differential GPS system will produce a positional uncertainty of only about 1 meter versus 3-5 meters for the differential system used on the aerial platforms and 100 meters for the autonomous GPS system.

The vehicle will first survey the wash areas south of the Double Tracks fenced area. The line spacing will be about 10 feet and the speed around $6 \mathrm{mph}$ ( 9 feet/second). 
The line length here is about 1 mile, so it will take about 10 minutes per line. The width of this area which must be surveyed will probably be determined by what is found during the first couple passes through the center of the plume seen in the aerial data. If we were to try to cover a 1000-foot wide, 1-mile long area with 10-foot spacing at $6 \mathrm{mph}$, we would need about 16 hours (at least two days). For this reason, if the pass through the hotest region doesn't discover anything unusual, the width of the survey will be greatly reduced.

The vehicle will then conduct its operations within the fenced area the remainder of the week. The survey inside the fence will begin in the bottom haif of the area and gradually work its way north. Some of the area will include regions searched by the ATV and mined of the hot chunks. This will provide further confirmation on the efficacy of the mining technique (as demonstrated in one location during the first trip) and may verify that large regions of the fenced area are below the radiation limits being proposed for the cleanup operation.

(3) This process will use the Suburban vehicie with the mast and collimated HPGe detector. The vehicle will made measurements at various locations in and around the Double Tracks area On the first work day, the vehicle will make a series of measurements outside the fenced area. These measurements will serve as a measurement of the "background" radiation field for reference after the site cleanup operations. On the remaining days, the Suburban will make measurements at selected locations within the fenced area.

\section{Acquisition \& Logistics Plan}

The survey crew consists of four people from EG\&G with several workers borrowed from IT Corp. and/or REECo. (There are a very limited number of peopie with the required OSHA training available during this time period.) The crew will travel to the survey site on the morning of Monday, 5 June, get rooms and check out the equipment in the afternoon. The REECo people will set up the hot line and monitoring facilities Monday aftemoon so that the site is ready for work to begin Tuesday morning. The crew will collect data all day Tuesday through Friday morning, and then pack up and travel back to Las Vegas Friday afternoon. 
A general description of the day-to-day activities is presented in the table below. The table shows all of the activity by EG\&G personnel. Activities by other organizations are not shown in this schedule.

\begin{tabular}{ll}
\hline \hline Date/Participant & Activity \\
\hline 15-31 May & Time window for Suburban and ATV detector calibration tests \\
1-2 June & $\begin{array}{l}\text { Pack equipment into van; } \\
\text { Last minute instructions on new equipment }\end{array}$ \\
Monday, 5 June & $\begin{array}{l}\text { Travel to Double Tracks in morning; } \\
\text { Get rooms and check operation of detectors in afternoon; } \\
\text { REECo establishes hotline at site }\end{array}$ \\
Tuesday, 6 June & \\
NaI Suburban & Conduct measurements south of fenced area \\
HPGe Suburban & Conduct spot measurements in "Bkgnd" areas outside fence \\
ATV & Conduct search for hot particles inside fence \\
Wednesday, 7 June & \\
NaI Suburban & Conduct measurements inside fenced area \\
HPGe Suburban & Conduct spot measurements inside Double Tracks fenced area \\
ATV & Additional search for hot particles (?) \\
Thursday, 8 June & \\
NaI Suburban & Conduct measurements inside fenced area \\
HPGe Suburban & Conduct spot measurements inside Double Tracks fenced area \\
ATV & Probably no activity \\
Friday, 9 June & \\
All & In morning, finish any work from previous days \\
All & Retum to Las Vegas in afternoon \\
\hline \hline
\end{tabular}

\section{Site Characteristics}

The survey is not planned to cover the whole Double Tracks area. Instead, the intent is to perform a preliminary characterization of the area, concentrating the measurements in areas of higher activity. The Double Tracks site is situated on an arid piain on the Nellis Air Force Bombing and Gunnery Range (NAFR). Access is through the Tonopah Test Range (TIR) and the crew will be staying in the dormatories on base. 
The contacts identified so far are listed in the following table.

Contacts

\begin{tabular}{lcc}
\hline \multicolumn{1}{c}{ Name } & Organization & Telephone \# \\
\hline Craig Lyons & REECo Health Physics Dept. & $(702) 295-0781$ \\
Wayne Bliss & REECo & $(702) 295-0540$ \\
J. R. McKinley & T Corp. & $(702) 794-1703$ \\
Monica Sanchez & DOE/ER & $(702) 295-0160$ \\
\hline \hline
\end{tabular}

\section{Risk Documents}

The ground-based operations associated with this survey have been addressed in several documents. The overall Health and Safety Plan (HASP) for work by the different organizations at Double Tracks is currently being created by REECo and IT Corporation. In addition, REECo and IT will prepare a Radiological Work Permit (RWP) for the work to be performed at Double Tracks. An assessment of the risks involved with the HPGe detector in situ measurements routinely conducted by EG\&G is presented in the "Risk Assessment for Radiation Science Section" document (August 31, 1994).

All EG\&G participants in the survey have attended the 40-hour OSHA 1910.120 training for Hazardous Waste Sites and have been fitted for respirators. The use of respirators is only expected if the survey area is very $\mathrm{dry}$ and the activity in the area raises appreciable amounts of dust into the air. All participants have attended the Radiological Worker II class. Explosive Ordinance (EOD). Training was conducted by Nellis AF personnel before the first trip to TTR and will be repeated for the new crew members on 18 May. 


\section{Cost Estimate}

The table below summarizes the costs for this survey under the "Double Tracks" job number of S3FEA100. The preparation costs shown are only those needed to coordinate the survey for the field. The preparation work to get the NaI Suburban and the ATV systems ready for fieid use are being conducted under the job numbers assigned to the development of those systems. There are no "Analysis and Report Costs". listed with this mission since a combined report of the April and June trips will be made and these costs have already been assembled under the cost estimate for that first trip.

\begin{tabular}{|c|c|c|c|c|}
\hline Item & $\begin{array}{l}\text { Preparation } \\
\text { Costs }\end{array}$ & Field Costs & $\begin{array}{l}\text { Analysis and } \\
\text { Report Costs }\end{array}$ & Totals \\
\hline Labor & $\$ 10 K$ & $\$ 16 \mathrm{~K}$ & soK & \$26K \\
\hline Travel & SOK & $\$ 2 \mathrm{~K}$ & SOK & $\$ 2 K$ \\
\hline Aircraft & SOK & SOK & SOK & \$OK \\
\hline$M \& S$ & SOK & S1K & SOK & $\$ 1 K$ \\
\hline Totals & $\$ 10 \mathrm{~K}$ & S19K & SOK & \$29K \\
\hline
\end{tabular}

The cost of each "down day" in the field (days when no useful survey work can be done due to inclement weather or other problems) is: $\$ 4 \mathrm{~K}$

\section{Deliverables/Reports and Deadlines}

The Double Tracks in situ gamma measurements will collect data on the americium concentration at the site. EG\&G will write a single report summarizing the results of the April and June trips.

The present schedule and plan specifiés that préliminary résults will be given to the project organizers when we leave Double Tracks at the end of the survey. A more-polished letter report (after completing our in-house scientific review and passing through our Reports Section) will be ready for customer review five months later. The final version of the report will be ready one to two months after the customer review is complete. 


\section{Attachment 1}

\section{Operations Safety Guidelines}

1. The Mission Manager shall ensure that the mission is safely conducted and ensures that crew members are familiar with the procedures outlined in Manual 32: "Safety", pertinent to mission operations.

2. The Mission Manager shail appoint a Safety Coordinator from the survey crew if an RSL safety staff member is not available.

NOTE: Appointment of a Safety Coordinator from the RSL safety staff is an Operations Manager's decision.

3. The Mission Manager and Safety Coordinator will review the mission pian, pertinent policies and procedures, and establish general safety coordination for mission conduct in the following categories:

a. In-house preparation (in conjunction with the RSL safety officer).

(1) System characterization.

(2) Packing and loading.

(3) Deployment.

b. Field Operations in addition to the above items:

(1) Site-specific safety requirements and FBO requirements.

(2) Non-operational safety precautions.

4. The Safety Coordinator shall monitor safety practices from the inception of mission operations through mission completion and system restoration to operational status.

NOTE: The pilot(s) will be primarily responsible for implementing guidelines related to aircraft and flight safety; however, the safety coordinator shall monitor aircraft operations and assist with handling safety concerns" whenever practical.

5. The Safety Coordinator shall conduct general safety briefings in conjunction with general briefings by the Mission Mariager or other briefings where safety concerns are deemed necessary.

6. The pilots shall advise the Mission Manager and the Safety Coordinator on mission safety concerns relative to aircraft and flight operations. 
7. During the mission, the mission safety coordinator shall:

a. Monitor mission tasks for safety hazards and unsafe acts.

b. Act as focal point for reporting and resoiving safety problems.

c. Provide a daily safety status report to the Mission Manager for inclusion into the daily mission status report.

8. The pilot shall monitor all aspects of air crew, aircraft and associated support equipment safety.

a. Flight safety briefings will be conducted prior to any mission flights and as outlined in the appropriate flight safety regulation during flights.

b. The pilot and mechanic shall collectiveiy monitor aircraft maintenance safety.

c. The command pilot for the mission shall submit a general flight safety report to the Mission Manager and Safety Coordinator to be included in the Mission Manager's general daily status report.

d. The pilot will continuously monitor the area weather conditions for foul weather indications so that the Mission Manager can adjust flight schedules accordingly.

9. Crew members shall:

a Perform tasks safely with particular attention given to but not limited to: driving, lifting, hauling, carrying, climbing, and installing equipment. In particular, care will be exercised when performing any of these tasks in an unfamiliar environment.

b. Wear appropriate safety gear as required by the task or circumstance.

c. Monitor the work area(s) for any safety act or hazard that may affect coworkers.

d. Report any unsafe conditions or acts to the Safety Coordinator or Mission Manager. 


\section{Attachment 2}

\section{Survey Parameters}

Mission Name: $\quad$ Double Tracks In Situ Survey

Location: Nellis Air Force Bombing and Gunnery Range, Nevada

Base of Operation: Tonopah Test Range Base

Survey type: $\quad$ Gamma Radiation

Aircraft: none

Nominal elevation: 1450 to $1520 \mathrm{~m}(4800$ to $5000 \mathrm{ft}) \mathrm{MSL}$

Survey Dimensions: (1) $<1000-\times 5000$-feet and (2) $700-\times 1500$-feet

Survey Altitude: $\quad 2.5$ feet

Line Spacing: $\quad 10$ feet

Line Direction: (1) neariy N-S and (2) E-W

Vehicle Speed: $\quad 6 \mathrm{mph}$

Number of lines: $\quad<250$

Total line length: $\quad<120$ miles

Total time: $\quad<25$ hours

Total survey days: 5

Navigation System: John Chance differential GPS

Detector Arrays: Suburban vehicie equipped with NaI pods and REDAR IV also:

ATV equipped with three FDLER detectors

Tripod-mounted HPGe detector

Suburban vehicle equipped with collimated HPGe detector on extendable mast 


\section{Appendix C}

Soil Sample Analytical Data 

Table C-1

Summary of Laboratory Analyses for Characterization Event 1

Soil Samples at the Double Tracks Test Site

(Page 1 of 2)

\begin{tabular}{|c|c|c|c|c|c|c|c|c|}
\hline \multirow[b]{2}{*}{$\begin{array}{l}\text { Sample } \\
\text { Number }\end{array}$} & \multirow[b]{2}{*}{$\begin{array}{l}\text { Sample } \\
\text { Location }\end{array}$} & \multirow{2}{*}{$\begin{array}{l}\text { Interval } \\
\text { Depth } \\
\text { (Inches) }\end{array}$} & \multicolumn{6}{|c|}{ Analytical Parameter } \\
\hline & & & $\begin{array}{l}\text { Isotopic } \\
\text { Plutonium }\end{array}$ & Am-241 & $\begin{array}{l}\text { Isotopic } \\
\text { Uranium }\end{array}$ & $\begin{array}{c}\text { Gamma } \\
\text { Spec. }\end{array}$ & $\begin{array}{l}\text { TAL } \\
\text { Metals }\end{array}$ & $\begin{array}{l}\text { TCLP } \\
\text { RCRA } \\
\text { Metals }\end{array}$ \\
\hline DT00002 & 1 & 0 to 2 & $x$ & $\underline{x}$ & $x$ & $x$ & $x$ & \\
\hline DT00003 & 1 & 2 to 4 & $x$ & $x$ & $x$ & & & \\
\hline DTO0004 & 1 & 4 to 6 & $x$ & $x$ & $x$ & & & \\
\hline DT00006 & 2 & 0 to 2 & $\underline{x}$ & $\underline{x}$ & $x$ & $x$ & $\underline{x}$ & \\
\hline DT00007 & 2 & 2 to 4 & $\underline{x}$ & $x$ & $x$ & & & \\
\hline DTO0008 & $\underline{2}$ & 4 to 6 & $\underline{x}$ & $\underline{x}$ & $x$ & & & \\
\hline DT00010 & 3 & 0 to 2 & $x$ & $x$ & $x$ & $x$ & $\underline{x}$ & \\
\hline DTO0011 & 3 & 2 to 4 & $\underline{x}$ & $\underline{x}$ & $\underline{x}$ & & & \\
\hline DT00012 & 3 & 4 to 6 & $\underline{x}$ & $x$ & $\underline{x}$ & & & \\
\hline DTO0014 & 4 & 0 to 2 & $\underline{x}$ & $x$ & $x$ & $\underline{x}$ & $x$ & \\
\hline DT00015 & 4 & 2 to 4 & $x$ & $\underline{x}$ & $x$ & & & \\
\hline DT00016 & 4 & 4 to 6 & $\underline{x}$ & $\underline{x}$ & $\underline{x}$ & & & \\
\hline DTO0018 & $F^{b}$ & $N^{c}$ & $\underline{x}$ & $\underline{x}$ & $\underline{x}$ & $x$ & $x$ & \\
\hline DTO0019 & 5 & 0 to 2 & $\underline{x}$ & $x$ & $x$ & $x$ & $\underline{x}$ & \\
\hline DTO0020 & 5 & 2 to 4 & $\underline{x}$ & $\underline{x}$ & $\underline{x}$ & & & \\
\hline DT00021 & 5 & 4 to 6 & $\underline{x}$ & $x$ & $x$ & & & \\
\hline DTO0022 & 5 & 4 to 6 & $x$ & $x$ & $x$ & & & \\
\hline DT00024 & 6 & 0 to 2 & $\underline{x}$ & $\underline{x}$ & $\underline{x}$ & $\underline{x}$ & $x$ & \\
\hline DTO0025 & 6 & 2 to 4 & $\underline{x}$ & $x$ & $x$ & & & \\
\hline DT00026 & 6 & 4 to 6 & $\underline{x}$ & $\underline{x}$ & $\underline{x}$ & & & \\
\hline DT00028 & 7 & 0 to 2 & $\underline{x}$ & $x$ & $\underline{x}$ & $x$ & $x$ & \\
\hline DT00029 & 7 & 2 to 4 & $\underline{x}$ & $\underline{x}$ & $x$ & & & \\
\hline DT00030 & 7 & 4 to 6 & $x$ & $x$ & $x$ & & & \\
\hline
\end{tabular}

Refer to footnotes at end of table. 
Table C-1

Summary of Laboratory Analyses for Characterization Event 1

Soil Samples at the Double Tracks Test Site

(Page 2 of 2)

\begin{tabular}{|c|c|c|c|c|c|c|c|c|}
\hline \multirow{2}{*}{$\begin{array}{l}\text { Sample } \\
\text { Number }\end{array}$} & \multirow{2}{*}{$\begin{array}{l}\text { Sample } \\
\text { Location }\end{array}$} & \multirow{2}{*}{$\begin{array}{c}\text { Interval } \\
\text { Depth } \\
\text { (inches) }\end{array}$} & \multicolumn{6}{|c|}{ Analytical Parameter" } \\
\hline & & & $\begin{array}{l}\text { Isotopic } \\
\text { Plutonium }\end{array}$ & Am-241 & $\begin{array}{l}\text { Isotopic } \\
\text { Uranium }\end{array}$ & $\begin{array}{c}\text { Gamma } \\
\text { Spec. }\end{array}$ & $\begin{array}{l}\text { TAL } \\
\text { Metals }\end{array}$ & $\begin{array}{l}\text { TCLP } \\
\text { RCRA } \\
\text { Metals }\end{array}$ \\
\hline DT00032 & 8 & 0 to 2 & $\underline{x}$ & $x$ & $\mathrm{x}$ & $x$ & $x$ & \\
\hline DT00033 & 8 & 2 to 4 & $\underline{x}$ & $x$ & $x$ & & & \\
\hline DT00034 & 8 & 4 to 6 & $\underline{x}$ & $x$ & $x$ & & & \\
\hline DT00036 & 9 & 0 to 2 & $\mathrm{x}$ & $x$ & $\underline{x}$ & $x$ & & $\underline{x}$ \\
\hline DT00037 & 9 & 2 to 4 & $x$ & $x$ & $x$ & & & \\
\hline DTO0038 & 9 & 4 to 6 & $\underline{x}$ & $x$ & $x$ & & & \\
\hline DTO0040 & 10 & 0 to 2 & $x$ & $\underline{x}$ & $x$ & $x$ & & $\underline{x}$ \\
\hline DT00041 & 10 & 2 to 4 & $x$ & $x$ & $x$ & & & \\
\hline DT00042 & 10 & 4 to 6 & $x$ & $x$ & $\mathbf{x}$ & & & \\
\hline DT00043 & 10 & 4 to 6 & $x$ & $\underline{x}$ & $x$ & & & \\
\hline DT00045 & 11 & 0 to 2 & $x$ & $x$ & $x$ & $x$ & & $x$ \\
\hline DT00046 & 11 & 2 to 4 & $\mathrm{x}$ & $x$ & $x$ & & & \\
\hline DT00047 & 11 & 4 to 6 & $x$ & $x$ & $x$ & & & \\
\hline DT00049 & 12 & 0 to 2 & $x$ & $x$ & $x$ & $\underline{x}$ & $x$ & \\
\hline DTO0050 & 12 & 2 to 4 & $x$ & $x$ & $x$ & & & \\
\hline DT00051 & 12 & 4 to 6 & $x$ & $x$ & $x$ & & & \\
\hline
\end{tabular}

analytical Parameter:

Isotopic Plutonium; Plutonium-238,-239/240 (Method NAS-NS-3058)

Am-241; Americium-241 (Method NAS-NS-3006)

Isotopic Uranium; Uranium-234,-235/236,-238 (Method NAS-NS-3050)

Gamma Spec.; Gamma Spectroscopy (Method HASL 300)

TAL Metals; Target Analyte List Metals (Method [CLP] Contract Laboratory Procedure)

TCLP/RCRA Metals; Toxicity Characteristic Leaching Procedure/Resource Conservation and Recovery Act Metals (Methods EPA 6010/7470).

bField Blank.

Not Applicable. 


\section{Table C-2}

\section{Summary of Laboratory Analyses for Characterization Event 2 Soil Samples at the Double Tracks Test Site}

\begin{tabular}{|c|c|c|c|c|c|}
\hline \multirow[b]{2}{*}{$\begin{array}{l}\text { Sample } \\
\text { Number }\end{array}$} & \multirow[b]{2}{*}{ Sample Location } & \multicolumn{4}{|c|}{ Analytical Parameter ${ }^{2}$} \\
\hline & & $\begin{array}{l}\text { Isotopic } \\
\text { Plutonium }\end{array}$ & Am-241 & $\begin{array}{c}\text { Total } \\
\text { Uranium }\end{array}$ & $\begin{array}{l}\text { TCLP } \\
\text { RCRA } \\
\text { Metals }\end{array}$ \\
\hline DT00100 & Hot Spot \#1 & $x$ & $x$ & $x$ & $x$ \\
\hline DT00101 & Hot Spot \#2 & $\mathbf{x}$ & $x$ & $x$ & \\
\hline DT00102 & Hot Spot \#3 & $x$ & $\mathrm{x}$ & $\mathrm{x}$ & $\underline{x}$ \\
\hline DT00103 & Hot Spot \#4 & $x$ & $\mathrm{x}$ & $\mathrm{x}$ & $x$ \\
\hline DT00104 & Hot Spot \#5 & $x$ & $x$ & $\mathrm{x}$ & $x$ \\
\hline DT00105 & Hot Spot \#6 & $x$ & $x$ & $x$ & \\
\hline
\end{tabular}

analytical Parameter:

Isotopic Plutonium; Plutonium-238,-239/240 (Method NAS-NS-3058)

Am-241; Americium-241 (Method NAS-NS-3006)

Total Uranium; (Method ASTM 5174-91)

TCLP/RCRA Metals; Toxicity Characteristic Leaching Procedure/Resource

Conservation and Recovery Act Metals (Methods EPA 6010/7470). 
Appendix C

NAEG Soil Laboratory Results and In Situ Radioactivity Measurements

\begin{tabular}{|c|c|c|c|c|c|c|}
\hline Location & Easting & Northing & Strata & Stake & $\begin{array}{r}\text { Plutonium } \\
\mathrm{pCl} / \mathrm{g}\end{array}$ & $\begin{array}{c}\text { FIDLER } \\
\text { counts/sec }\end{array}$ \\
\hline DT & 1074833 & 407000 & 1 & 1 & 471 & 2300 \\
\hline DT & 1074485 & 407112 & 1 & 2 & 14.5 & 1300 \\
\hline DT & 1074588 & 407175 & 1 & 3 & 0 & 1300 \\
\hline DT & 1074067 & 406934 & 1 & 4 & 51.2 & 1300 \\
\hline DT & 1075363 & 407092 & 1 & 5 & 291 & 4300 \\
\hline DT & 1075866 & 407296 & 1 & 6 & 0 & 1300 \\
\hline DT & 1075564 & 407196 & 1 & 7 & 0 & 1300 \\
\hline DT & 1076626 & 407037 & 1 & 8 & 0 & 1300 \\
\hline DT & 1074942 & 407192 & 1 & 9 & 3.3 & 1300 \\
\hline DT & 1073864 & 407057 & 1 & 10 & 0 & 1300 \\
\hline DT & 1076999 & 407407 & 1 & 11 & 1.18 & 1300 \\
\hline DT & 1075218 & 407275 & 1 & 12 & 2.07 & 1300 \\
\hline DT & 1076445 & 407394 & 1 & 13 & 0 & 1300 \\
\hline DT & 1076973 & 407228 & 1 & 14 & 5.25 & 1.300 \\
\hline DT & 1074334 & 407166 & 1 & 15 & 0 & 1300 \\
\hline DT & 1076902 & 407139 & 1 & 16 & 1.55 & 1300 \\
\hline DT & 1075443 & 406917 & 1 & 17 & 0 & 1300 \\
\hline DT & 1074741 & 407148 & 1 & 18 & 0.86 & 1300 \\
\hline DT & 1074151 & 407035 & 1 & 19 & 378 & 2300 \\
\hline DT & 1076672 & 406918 & 1 & 20 & 0.52 & 1300 \\
\hline DT & 1076670 & 407273 & 1 & 21 & 5.57 & 1300 \\
\hline DT & 1074423 & 407180 & 1 & 22 & 30 & 1300 \\
\hline DT & 1074328 & 407124 & 1 & 23 & 0 & 1300 \\
\hline DT & 1074937 & 407339 & 1 & 24 & 18.3 & 1300 \\
\hline DT & 1075054 & 407365 & 1 & 25 & 1.04 & 1300 \\
\hline DT & 1074339 & 406902 & 1 & 26 & 0 & 1300 \\
\hline DT & 1076524 & 407186 & 1 & 27 & 8.2 & 1300 \\
\hline DT & 1075575 & 407443 & 1 & 28 & 5.68 & 1300 \\
\hline DT & 1073914 & 406837 & 1 & 29 & 33.7 & 1300 \\
\hline DT & 1074620 & 407195 & 1 & 30 & 0 & 1300 \\
\hline DT & 1074789 & 407028 & 1 & 31 & 1290 & 2800 \\
\hline DT & 1076953 & 407399 & 1 & 32 & 0 & 1300 \\
\hline DT & 1074797 & 407145 & 1 & 33 & 0 & 1300 \\
\hline DT & 1073860 & 407021 & 1 & 34 & 0 & 1300 \\
\hline DT & 1076436 & 407109 & 1 & 35 & 0 & 1300 \\
\hline DT & 1076015 & 407042 & 1 & 36 & 60.8 & 1300 \\
\hline DT & 1075639 & 407004 & 1 & 37 & 10.6 & 1300 \\
\hline DT & 1074159 & 406973 & 1 & 38 & 0 & 1300 \\
\hline DT & 1073941 & 406791 & 1 & 39 & 3.69 & 1300 \\
\hline DT & 1076233 & 407167 & 2 & 1 & 219 & 1800 \\
\hline DT & 1076263 & 407238 & 2 & 2 & 410 & 1800 \\
\hline DT & 1076135 & 407175 & 2 & 3 & 0 & 2300 \\
\hline DT & 1076282 & 407250 & 2 & 4 & 386 & 1800 \\
\hline DT & 1076264 & 407273 & 2 & 5 & 608 & 3300 \\
\hline DT & 1076034 & 407233 & 2 & 6 & 0 & 4800 \\
\hline DT & 1076221 & 407162 & 2 & 7 & 28.7 & 1800 \\
\hline DT & 1076284 & 407201 & 2 & 8 & 10.1 & 1800 \\
\hline
\end{tabular}


Appendix C

NAEG Soil Laboratory Results and In Situ Radioactivity Measurements

\begin{tabular}{|c|c|c|c|c|c|c|}
\hline Location & Easting & Northing & Strata & Stake & $\begin{array}{r}\text { Plutonium } \\
\mathrm{pCi} / \mathrm{g}\end{array}$ & $\begin{array}{c}\text { FIDLER } \\
\text { counts/sec }\end{array}$ \\
\hline DT & 1076077 & 407249 & 2 & 9 & 629 & 3300 \\
\hline DT & 1076206 & 407197 & 2 & 10 & 0 & 27000 \\
\hline DT & 1076202 & 407182 & 2 & 11 & 39500 & 17300 \\
\hline DT & 1076075 & 407193 & 2 & 12 & 0 & 6000 \\
\hline DT & 1076255 & 407242 & 2 & 13 & 13500 & 22000 \\
\hline DT & 1076602 & 407218 & 2 & 14 & 1690 & 4000 \\
\hline DT & 1076107 & 407263 & 2 & 15 & 0 & 4300 \\
\hline DT & 1076284 & 407193 & 2 & 16 & 0 & 1300 \\
\hline DT & 1076627 & 407306 & 2 & 17 & 15.3 & 1300 \\
\hline DT & 1076239 & 407249 & 3 & 1 & 4290 & 7000 \\
\hline DT & 1076231 & 407193 & 3 & 2 & 0 & 2000 \\
\hline DT & 1076219 & 407238 & 3 & 3 & 5930 & 17000 \\
\hline DT & 1076198 & 407203 & 3 & 4 & 5360 & 36400 \\
\hline DT & 1076117 & 407186 & 3 & 5 & 3410 & 1800 \\
\hline DT & 1076119 & 407200 & 3 & 6 & 1180 & 9300 \\
\hline DT & 1076017 & 407185 & 3 & 7 & 2570 & 7000 \\
\hline DT & 1076128 & 407185 & 3 & 8 & 184 & 4200 \\
\hline DT & 1076240 & 407189 & 3 & 9 & 1610 & 5000 \\
\hline DT & 1076139 & 407239 & 3 & 10 & 5140 & 17000 \\
\hline DT & 1076219 & 407252 & 3 & 11 & 9760 & 17000 \\
\hline DT & 1076173 & 407293 & 3 & 12 & 12100 & 39000 \\
\hline DT & 1076272 & 407235 & 3 & 13 & 951 & 1800 \\
\hline DT & 1076078 & 407107 & 3 & 14 & 8.43 & 1800 \\
\hline DT & 1076056 & 407189 & 3 & 15 & 136 & 5300 \\
\hline DT & 1076157 & 407207 & 3 & 16 & 14800 & 17000 \\
\hline DT & 1076168 & 407300 & 3 & 17 & 792 & 7300 \\
\hline DT & 1076174 & 407226 & 4 & 1 & 12400 & 17300 \\
\hline DT & 1076229 & 407284 & 4 & 2 & 36100 & 41700 \\
\hline DT & 1076175 & 407257 & 4 & 3 & 0 & 46700 \\
\hline DT & 1076198 & 407270 & 4 & 4 & 68300 & 174900 \\
\hline DT & 1076182 & 407260 & 4 & 5 & 39600 & 96400 \\
\hline DT & 1076235 & 407243 & 4 & 6 & 5450 & 22000 \\
\hline DT & 1076184 & 407287 & 4 & 7 & 27900 & 89700 \\
\hline DT & 1076141 & 407229 & 4 & 8 & 2350 & 17000 \\
\hline DT & 1076209 & 407291 & 4 & 9 & 118000 & 224000 \\
\hline DT & 1076245 & 407255 & 4 & 10 & 1520 & 2300 \\
\hline DT & .1076205 & 407267 & 4 & 11 & 18900 & 47000 \\
\hline DT. & 1076196 & 407253 & 4 & 12 & 77500 & 115200 \\
\hline DT & 1076215 & 407280 & 4 & 13 & 1540 & 4000 \\
\hline DT & 1076155 & 407264 & 4 & 14 & 0 & 12300 \\
\hline DT & 1076227 & 407287 & 4 & 15 & 111000 & 135800 \\
\hline DT & 1076153 & 407223 & 4 & 16 & 10900 & 37000 \\
\hline DT & 1076173 & 407437 & 4 & 17 & 29500 & 86700 \\
\hline
\end{tabular}


Appendix C

Laboratory Results for Target Analyte List Constituents in Soil (plus field and laboratory QAQC)

First Characterization Event

\begin{tabular}{|c|c|c|c|c|c|}
\hline $\begin{array}{l}\text { Sample } \\
\text { Number }\end{array}$ & Analyte & Result & Units & Qualifier & Matrix \\
\hline DT00002 & Aluminum & 6390 & $\mathrm{mg} / \mathrm{kg}$ & & Soil \\
\hline DT00002 & Antimony & 9.3 & $\mathrm{mg} / \mathrm{kg}$ & $\mathbf{U}$ & Soil \\
\hline DT00002 & Arsenic & 2.7 & $\mathrm{mg} / \mathrm{kg}$ & & Soil \\
\hline DT00002 & Barium & 140 & $\mathrm{mg} / \mathrm{kg}$ & & Soil \\
\hline DT00002 & Beryllium & 0.64 & $\mathrm{mg} / \mathrm{kg}$ & B & Soil \\
\hline DT00002 & Cadmium & 0.75 & $\mathrm{mg} / \mathrm{kg}$ & U & Soil \\
\hline DT00002 & Calcium & 11700 & $\mathrm{mg} / \mathrm{kg}$ & & Soil \\
\hline DTO0002 & Chromium & 3.3 & $\mathrm{mg} / \mathrm{kg}$ & & Soil \\
\hline DT00002 & Cobalt & 4.1 & $\mathrm{mg} / \mathrm{kg}$ & B & Soil \\
\hline DT00002 & Copper & 6.9 & $\mathrm{mg} / \mathrm{kg}$ & & Soil \\
\hline DT00002 & Iron & 8220 & $\mathrm{mg} / \mathrm{kg}$ & & Soil \\
\hline DT00002 & Lead & 9.5 & $\mathrm{mg} / \mathrm{kg}$ & & Soil \\
\hline DT00002 & Magnesium & 3090 & $\mathrm{mg} / \mathrm{kg}$ & & Soil \\
\hline DT00002 & Manganese & 385 & $\mathrm{mg} / \mathrm{kg}$ & & Soil \\
\hline DTO0002 & Mercury & 0.051 & $\mathrm{mg} / \mathrm{kg}$ & $\mathrm{U}$ & Soil \\
\hline DT00002 & Nickel & 4.8 & $\mathrm{mg} / \mathrm{kg}$ & B & Soil \\
\hline DT00002 & Potassium & 3800 & $\mathrm{mg} / \mathrm{kg}$ & & Soil \\
\hline DT00002 & Selenium & 0.34 & $\mathrm{mg} / \mathrm{kg}$ & $\mathrm{U}$ & Soil \\
\hline DT00002 & Silver & 0.77 & $\mathrm{mg} / \mathrm{kg}$ & $\mathrm{U}$ & Soil \\
\hline DT00002 & Sodium & 386 & $\mathrm{mg} / \mathrm{kg}$ & $B$ & Soil \\
\hline DT00002 & Vanadium & 12.4 & $\mathrm{mg} / \mathrm{kg}$ & & Soil \\
\hline DT00002 & Zinc & 25.5 & $\mathrm{mg} / \mathrm{kg}$ & & Soil \\
\hline DT00002 Dup & Aluminum & 8830 & $\mathrm{mg} / \mathrm{kg}$ & & Soil \\
\hline DT00002 Dup & Antimony & 9.3 & $\mathrm{mg} / \mathrm{kg}$ & $\mathrm{U}$ & Soil \\
\hline DT00002 Dup & Arsenic & 2.2 & $\mathrm{mg} / \mathrm{kg}$ & & Soil \\
\hline DT00002 Dup & Barium & 172 & $\mathrm{mg} / \mathrm{kg}$ & & Soil \\
\hline DT00002 Dup & Beryllium & 0.73 & $\mathrm{mg} / \mathrm{kg}$ & $B$ & Soil \\
\hline DTO0002 Dup & Cadmium & 0.75 & $\mathrm{mg} / \mathrm{kg}$ & $\mathrm{U}$ & Soil \\
\hline DT00002 Dup & Calcium & 11600 & $\mathrm{mg} / \mathrm{kg}$ & & Soil \\
\hline DT00002 Dup & Chromium & 4.1 & $\mathrm{mg} / \mathrm{kg}$ & & Soil \\
\hline DT00002 Dup & Cobalt & 4.5 & $\mathrm{mg} / \mathrm{kg}$ & $B$ & Soil \\
\hline DT00002 Dup & Copper & 7.7 & $\mathrm{mg} / \mathrm{kg}$ & & Soil \\
\hline DTO0002 Dup & iron & 9970 & $\mathrm{mg} / \mathrm{kg}$ & & Soil \\
\hline DT00002 Dup & Lead & 8.9 & $\mathrm{mg} / \mathrm{kg}$ & & Soil \\
\hline DTO0002 Dup & Magnesium & 3550 & $\mathrm{mg} / \mathrm{kg}$ & & Soil \\
\hline DT00002 Dup & Manganese & 409 & $\mathrm{mg} / \mathrm{kg}$ & & Soil \\
\hline DT00002 Dup & Mercury & 0.065 & $\mathrm{mg} / \mathrm{kg}$ & $B$ & Soil \\
\hline DT00002 Dup & Nickel & 5.7 & $\mathrm{mg} / \mathrm{kg}$ & $\mathrm{B}$ & Soil \\
\hline DT00002 Dup & Potassium & 5360 & $\mathrm{mg} / \mathrm{kg}$ & & Soil \\
\hline DT00002 Dup & Selenium & 0.34 & $\mathrm{mg} / \mathrm{kg}$ & $\mathrm{U}$ & Soil \\
\hline DT00002 Dup & Silver & 0.77 & $\mathrm{mg} / \mathrm{kg}$ & $U$ & Soil \\
\hline DT00002 Dup & Sodium & 523 & $\mathrm{mg} / \mathrm{kg}$ & $B$ & Soil \\
\hline DT00002 Dup & Thallium & 0.3 & $\mathrm{mg} / \mathrm{kg}$ & U & Soil \\
\hline DT00002 Dup & Thallium & 0.3 & $\mathrm{mg} / \mathrm{kg}$ & $\mathrm{U}$ & Soil \\
\hline DTO0002 Dup & Vanadium & 16.6 & $\mathrm{mg} / \mathrm{kg}$ & & Soil \\
\hline DT00002 Dup & Zinc & 30.4 & $\mathrm{mg} / \mathrm{kg}$ & & Soil \\
\hline DT00006 & Aluminum & 9050 & $\mathrm{mg} / \mathrm{kg}$ & & Soil \\
\hline DT00006 & Antimony & 9.3 & $\mathrm{mg} / \mathrm{kg}$ & U & Soil \\
\hline
\end{tabular}


Appendix C

Laboratory Results for Target Analyte List Constituents in Soil (plus field and laboratory QAVQC)

First Characterization Event

\begin{tabular}{|c|c|c|c|c|c|}
\hline $\begin{array}{l}\text { Sample } \\
\text { Number }\end{array}$ & Analyte & Result & Units & Qualifier & Matrix \\
\hline DT00006 & Arsenic & 2.1 & $\mathrm{mg} / \mathrm{kg}$ & & Soil \\
\hline DT00006 & Barium & 182 & $\mathrm{mg} / \mathrm{kg}$ & & Soil \\
\hline DT00006 & Beryllium & 0.73 & $\mathrm{mg} / \mathrm{kg}$ & B & Soil \\
\hline DT00006 & Cadmium & 0.75 & $\mathrm{mg} / \mathrm{kg}$ & $\mathrm{U}$ & Soil \\
\hline DT00006 & Calcium & 12300 & $\mathrm{mg} / \mathrm{kg}$ & & Soil \\
\hline DT00006 & Chromium & 4.2 & $\mathrm{mg} / \mathrm{kg}$ & & Soil \\
\hline DT00006 & Cobalt & 4.3 & $\mathrm{mg} / \mathrm{kg}$ & B & Soil \\
\hline DT00006 & Copper & 6.2 & $\mathrm{mg} / \mathrm{kg}$ & & Soil \\
\hline DT00006 & Iron & 11000 & $\mathrm{mg} / \mathrm{kg}$ & & Soil \\
\hline DT00006 & Lead & 11.8 & $\mathrm{mg} / \mathrm{kg}$ & & Soil \\
\hline DT00006 & Magnesium & 3520 & $\mathrm{mg} / \mathrm{kg}$ & & Soil \\
\hline DT00006 & Manganese & 447 & $\mathrm{mg} / \mathrm{kg}$ & & Soil \\
\hline DT00006 & Mercury & 0.051 & $\mathrm{mg} / \mathrm{kg}$ & $u$ & Soil \\
\hline DTO0006 & Nickel & 5.6 & $\mathrm{mg} / \mathrm{kg}$ & $\mathrm{B}$ & Soil \\
\hline DT00006 & Potassium & 3600 & $\mathrm{mg} / \mathrm{kg}$ & & Soil \\
\hline DT00006 & Selenium & 0.35 & $\mathrm{mg} / \mathrm{kg}$ & $U$ & Soil \\
\hline DT00006 & Silver & 0.77 & $\mathrm{mg} / \mathrm{kg}$ & U & Soil \\
\hline DT00006 & Sodium & 385 & $\mathrm{mg} / \mathrm{kg}$ & $\mathrm{B}$ & Soil \\
\hline DT00006 & Thallium & 0.3 & $\mathrm{mg} / \mathrm{kg}$ & $U$ & Soil \\
\hline DT00006 & Vanadium & 19.2 & $\mathrm{mg} / \mathrm{kg}$ & & Soil \\
\hline DT00006 & Zinc & 33.5 & $\mathrm{mg} / \mathrm{kg}$ & & Soil \\
\hline DT00010 & Aluminum & 9460 & $\mathrm{mg} / \mathrm{kg}$ & & Soil \\
\hline DT00010 & Antimony & 9.3 & $\mathrm{mg} / \mathrm{kg}$ & U & Soil \\
\hline DTO0010 & Arsenic & 3.1 & $\mathrm{mg} / \mathrm{kg}$ & & Soil \\
\hline DT00010 & Barium & 151 & $\mathrm{mg} / \mathrm{kg}$ & & Soil \\
\hline DT00010 & Beryllium & 0.73 & $\mathrm{mg} / \mathrm{kg}$ & B & Soil \\
\hline DTO0010 & Cadmium & 0.75 & $\mathrm{mg} / \mathrm{kg}$ & $\mathbf{U}$ & Soil \\
\hline DT00010 & Calcium & 11100 & $\mathrm{mg} / \mathrm{kg}$ & & Soil \\
\hline DTO0010 & Chromium & 5.1 & $\mathrm{mg} / \mathrm{kg}$ & & Soil \\
\hline DT00010 & Cobalt & 4.9 & $\mathrm{mg} / \mathrm{kg}$ & B & Soil \\
\hline DT00010 & Copper & 7.3 & $\mathrm{mg} / \mathrm{kg}$ & & Soil \\
\hline DT00010 & Iron & 12200 & $\mathrm{mg} / \mathrm{kg}$ & & Soil \\
\hline DT00010 & Lead & 10.7 & $\mathrm{mg} / \mathrm{kg}$ & & Soil \\
\hline DT00010 & Magnesium & 3880 & $\mathrm{mg} / \mathrm{kg}$ & & Soil \\
\hline DT00010 & Manganese & 416 & $\mathrm{mg} / \mathrm{kg}$ & & Soil \\
\hline DTO0010 & Mercury & 0.05 & $\mathrm{mg} / \mathrm{kg}$ & $U$ & Soil \\
\hline DTO0010 & Nickel & 5.5 & $\mathrm{mg} / \mathrm{kg}$ & B & Soil \\
\hline DT00010 & Potassium & 4090 & $\mathrm{mg} / \mathrm{kg}$ & & Soil \\
\hline DT00010 & Selenium & 0.34 & $\mathrm{mg} / \mathrm{kg}$ & $U$ & Soil \\
\hline DT00010 & Silver & 0.77 & $\mathrm{mg} / \mathrm{kg}$ & $\mathbf{U}$ & Soil \\
\hline DT00010 & Sodium & 446 & $\mathrm{mg} / \mathrm{kg}$ & B & Soil \\
\hline DT00010 & Thallium & 0.3 & $\mathrm{mg} / \mathrm{kg}$ & $U$ & Soil \\
\hline DTO0010 & Vanadium & 19.2 & $\mathrm{mg} / \mathrm{kg}$ & & Soil \\
\hline DTO0010 & Zinc & 35.4 & $\mathrm{mg} / \mathrm{kg}$ & & Soil \\
\hline DTO0014 & Aluminum & 8660 & $\mathrm{mg} / \mathrm{kg}$ & & Soil \\
\hline DTO0014 & Antimony & 9.3 & $\mathrm{mg} / \mathrm{kg}$ & $U$ & Soil \\
\hline DT00014 & Arsenic & 2.2 & $\mathrm{mg} / \mathrm{kg}$ & & Soil \\
\hline DT00014 & Barium & 128 & $\mathrm{mg} / \mathrm{kg}$ & & Soil \\
\hline
\end{tabular}


Appendix C

Laboratory Results for Target Analyte List Constituents in Soil (plus field and laboratory QA/QC)

First Characterization Event

\begin{tabular}{|c|c|c|c|c|c|}
\hline $\begin{array}{l}\text { Sample } \\
\text { Number }\end{array}$ & Analyte & Result & Units & Qualifier & Matris \\
\hline DT00014 & Beryllium & 0.76 & $\mathrm{mg} / \mathrm{kg}$ & B & Soil \\
\hline DT00014 & Cadmium & 0.75 & $\mathrm{mg} / \mathrm{kg}$ & $U$ & Soil \\
\hline DT00014 & Calcium & 19800 & $\mathrm{mg} / \mathrm{kg}$ & & Soil \\
\hline DT00014 & Chromium & 5 & $\mathrm{mg} / \mathrm{kg}$ & & Soil \\
\hline DT00014 & Cobalt & 5.3 & $\mathrm{mg} / \mathrm{kg}$ & B & Soil \\
\hline DT00014 & Copper & 7.4 & $\mathrm{mg} / \mathrm{kg}$ & & Soil \\
\hline DT00014 & Iron & 13000 & $\mathrm{mg} / \mathrm{kg}$ & & Soil \\
\hline DT00014 & Lead & 11 & $\mathrm{mg} / \mathrm{kg}$ & & Soil \\
\hline DT00014 & Magnesium & 4200 & $\mathrm{mg} / \mathrm{kg}$ & & Soil \\
\hline DT00014 & Manganese & 394 & $\mathrm{mg} / \mathrm{kg}$ & & Soil \\
\hline DT00014 & Mercury & 0.051 & $\mathrm{mg} / \mathrm{kg}$ & $U$ & Soil \\
\hline DT00014 & Nickel & 7.3 & $\mathrm{mg} / \mathrm{kg}$ & B & Soil \\
\hline DT00014 & Potassium & 3960 & $\mathrm{mg} / \mathrm{kg}$ & & Soil \\
\hline DTO0014 & Selenium & 0.34 & $\mathrm{mg} / \mathrm{kg}$ & $\mathbf{U}$ & Soil \\
\hline DT00014 & Silver & 0.77 & $\mathrm{mg} / \mathrm{kg}$ & U & Soil \\
\hline DT00014 & Sodium & 476 & $\mathrm{mg} / \mathrm{kg}$ & B & Soil \\
\hline DT00014 & Thallium & 0.3 & $\mathrm{mg} / \mathrm{kg}$ & $\mathbf{U}$ & Soil \\
\hline DT00014 & Vanadium & 23.1 & $\mathrm{mg} / \mathrm{kg}$ & & Soil \\
\hline DT00014 & Zinc & 38 & $\mathrm{mg} / \mathrm{kg}$ & & Soil \\
\hline DT00018 & Aluminum & 21.2 & $\mathrm{mg} / \mathrm{kg}$ & B & Soil \\
\hline DT00018 & Antimony & 9.2 & $\mathrm{mg} / \mathrm{kg}$ & $\mathrm{U}$ & Soil \\
\hline DT00018 & Arsenic & 0.36 & $\mathrm{mg} / \mathrm{kg}$ & $\mathrm{U}$ & Soil \\
\hline DT00018 & Barium & 0.56 & $\mathrm{mg} / \mathrm{kg}$ & B & Soil \\
\hline DT00018 & Beryllium & 0.06 & $\mathrm{mg} / \mathrm{kg}$ & U & Soil \\
\hline DT00018 & Cadmium & 0.74 & $\mathrm{mg} / \mathrm{kg}$ & $\mathbf{U}$ & Soil \\
\hline DT00018 & Calcium & 242 & $\mathrm{mg} / \mathrm{kg}$ & B & Soil \\
\hline DT00018 & Chromium & 1.1 & $\mathrm{mg} / \mathrm{kg}$ & U & Soil \\
\hline DT00018 & Cobalt & 0.68 & $\mathrm{mg} / \mathrm{kg}$ & U & Soil \\
\hline DT00018 & Copper & 1.5 & $\mathrm{mg} / \mathrm{kg}$ & U & Soil \\
\hline DT00018 & Iron & 36.6 & $\mathrm{mg} / \mathrm{kg}$ & & Soil \\
\hline DT00018 & Lead & 0.72 & $\mathrm{mg} / \mathrm{kg}$ & & Soil \\
\hline DT00018 & Magnesium & 39.2 & $\mathrm{mg} / \mathrm{kg}$ & B & Soil \\
\hline DT00018 & Manganese & 2.3 & $\mathrm{mg} / \mathrm{kg}$ & $\mathbf{B}$ & Soil \\
\hline DT0001.8 & Mercury & 0.05 & $\mathrm{mg} / \mathrm{kg}$ & $\mathbf{U}$ & Soil \\
\hline DT00018 & Nickel & 3.1 & $\mathrm{mg} / \mathrm{kg}$ & U & Soil \\
\hline DT00018 & Potassium & 389 & $\mathrm{mg} / \mathrm{kg}$ & $\mathrm{U}$ & Soil \\
\hline DT00018 & Selenium & 0.34 & $\mathrm{mg} / \mathrm{kg}$ & $U$ & Soil \\
\hline DT00018 & Silver & 0.76 & $\mathrm{mg} / \mathrm{kg}$ & $\mathrm{U}$ & Soil \\
\hline DT00018 & Sodium & 70.5 & $\mathrm{mg} / \mathrm{kg}$ & B & Soil \\
\hline DT00018 & Thallium & 0.3 & $\mathrm{mg} / \mathrm{kg}$ & U & Soil \\
\hline DT00018 & Vanadium & 1.9 & $\mathrm{mg} / \mathrm{kg}$ & $U$ & Soil \\
\hline DT00018 & Zinc & 3.3 & $\mathrm{mg} / \mathrm{kg}$ & B & Soil \\
\hline DT00019 & Aluminum & 7090 & $\mathrm{mg} / \mathrm{kg}$ & & Soil \\
\hline DT00019 & Antimony & 9.3 & $\mathrm{mg} / \mathrm{kg}$ & $u$ & Soil \\
\hline DT00019 & Arsenic & 1.7 & $\mathrm{mg} / \mathrm{kg}$ & B & Soil \\
\hline DT00019 & Barium & 123 & $\mathrm{mg} / \mathrm{kg}$ & & Soil \\
\hline DTO0019 & Beryllium & 0.62 & $\mathrm{mg} / \mathrm{kg}$ & $B$ & Soil \\
\hline DT00019 & Cadmium & 0.75 & $\mathrm{mg} / \mathrm{kg}$ & U & Soil \\
\hline
\end{tabular}


Appendix C

Laboratory Results for Target Analyte List Constituents in Soil (plus field and laboratory QAQC)

First Characterization Event

\begin{tabular}{|c|c|c|c|c|c|}
\hline $\begin{array}{l}\text { Sample } \\
\text { Number }\end{array}$ & Analyte & Result & Units & Qualifier & Matris \\
\hline DT00019 & Calcium & 12000 & $\mathrm{mg} / \mathrm{kg}$ & & Soil \\
\hline DT00019 & Chromium & 4.4 & $\mathrm{mg} / \mathrm{kg}$ & & Soil \\
\hline DTO0019 & Cobalt & 4.2 & $\mathrm{mg} / \mathrm{kg}$ & B & Soil \\
\hline DT00019 & Copper & 7.1 & $\mathrm{mg} / \mathrm{kg}$ & & Soil \\
\hline DT00019 & Iron & 10300 & $\mathrm{mg} / \mathrm{kg}$ & & Soil \\
\hline DT00019 & Lead & 9.9 & $\mathrm{mg} / \mathrm{kg}$ & & Soil \\
\hline DT00019 & Magnesium & 3650 & $\mathrm{mg} / \mathrm{kg}$ & & Soil \\
\hline DT00019 & Manganese & 358 & $\mathrm{mg} / \mathrm{kg}$ & & Soil \\
\hline DT00019 & Mercury & 0.05 & $\mathrm{mg} / \mathrm{kg}$ & $U$ & Soil \\
\hline DTO0019 & Nickel & 6.3 & $\mathrm{mg} / \mathrm{kg}$ & B & Soil \\
\hline DT00019 & Potassium & 3290 & $\mathrm{mg} / \mathrm{kg}$ & & Soil \\
\hline DT00019 & Selenium & 0.34 & $\mathrm{mg} / \mathrm{kg}$ & U & Soil \\
\hline DT00019 & Silver & 0.77 & $\mathrm{mg} / \mathrm{kg}$ & $U$ & Soil \\
\hline DT00019 & Sodium & 524 & $\mathrm{mg} / \mathrm{kg}$ & $\mathbf{B}$ & Soil \\
\hline DT00019 & Thallium & 0.3 & $\mathrm{mg} / \mathrm{kg}$ & $U$ & Soil \\
\hline DT00019 & Vanadium & 15.3 & $\mathrm{mg} / \mathrm{kg}$ & & Soil \\
\hline DT00019 & Zinc & 33.4 & $\mathrm{mg} / \mathrm{kg}$ & & Soil \\
\hline DT00024 & Aluminum & 8330 & $\mathrm{mg} / \mathrm{kg}$ & & Soil \\
\hline DT00024 & Antimony & 9.3 & $\mathrm{mg} / \mathrm{kg}$ & U & Soil \\
\hline DT00024 & Arsenic & 3.2 & $\mathrm{mg} / \mathrm{kg}$ & & Soil \\
\hline DT00024 & Barium & 143 & $\mathrm{mg} / \mathrm{kg}$ & & Soil \\
\hline DT00024 & Beryllium & 0.73 & $\mathrm{mg} / \mathrm{kg}$ & B & Soil \\
\hline DT00024 & Cadmium & 0.75 & $\mathrm{mg} / \mathrm{kg}$ & $U$ & Soil \\
\hline DT00024 & Calcium & 16900 & $\mathrm{mg} / \mathrm{kg}$ & & Soil \\
\hline DT00024 & Chromium & 5.2 & $\mathrm{mg} / \mathrm{kg}$ & & Soil \\
\hline DT00024 & Cobalt & 5.4 & $\mathrm{mg} / \mathrm{kg}$ & B & Soil \\
\hline DT00024 & Copper & 9.8 & $\mathrm{mg} / \mathrm{kg}$ & & Soil \\
\hline DT00024 & Iron & 11200 & $\mathrm{mg} / \mathrm{kg}$ & & Soil \\
\hline DT00024 & Lead & 8.2 & $\mathrm{mg} / \mathrm{kg}$ & & Soil \\
\hline DT00024 & Magnesium & 4830 & $\mathrm{mg} / \mathrm{kg}$ & & Soil \\
\hline DT00024 & Manganese & 431 & $\mathrm{mg} / \mathrm{kg}$ & & Soil \\
\hline DT00024 & Mercury & 0.051 & $\mathrm{mg} / \mathrm{kg}$ & U & Soil \\
\hline DTO0024 & Nickel & 7.9 & $\mathrm{mg} / \mathrm{kg}$ & B & Soil \\
\hline DT00024 & Potassium & 4790 & $\mathrm{mg} / \mathrm{kg}$ & & Soil \\
\hline DT00024 & Selenium & 0.34 & $\mathrm{mg} / \mathrm{kg}$ & $u$ & Soil \\
\hline DT00024 & Silver & 0.77 & $\mathrm{mg} / \mathrm{kg}$ & $\mathrm{U}$ & Soil \\
\hline DT00024 & Sodium & 1110 & $\mathrm{mg} / \mathrm{kg}$ & & Soil \\
\hline DT00024 & Thallium & 0.3 & $\mathrm{mg} / \mathrm{kg}$ & U & Soil \\
\hline DT00024 & Vanadium & 17.7 & $\mathrm{mg} / \mathrm{kg}$ & & Soil \\
\hline DT00024 & Zinc & 41.3 & $\mathrm{mg} / \mathrm{kg}$ & & Soil \\
\hline DT00028 & Aluminum & 9360 & $\mathrm{mg} / \mathrm{kg}$ & & Soil \\
\hline DT00028 & Antimony & 9.3 & $\mathrm{mg} / \mathrm{kg}$ & $U$ & Soil \\
\hline DT00028 & Arsenic & 3.2 & $\mathrm{mg} / \mathrm{kg}$ & & Soil \\
\hline DT00028 & Barium & 159 & $\mathrm{mg} / \mathrm{kg}$ & & Soil \\
\hline DT00028 & Beryllium & 0.76 & $\mathrm{mg} / \mathrm{kg}$ & B & Soil \\
\hline DT00028 & Cadmium & 0.75 & $\mathrm{mg} / \mathrm{kg}$ & $\mathbf{U}$ & Soil \\
\hline DT00028 & Calcium & 14200 & $\mathrm{mg} / \mathrm{kg}$ & & Soil \\
\hline DT00028 & Chromium & 5.6 & $\mathrm{mg} / \mathrm{kg}$ & & Soil \\
\hline
\end{tabular}


Appendix C

Laboratory Results for Target Analyte List Constituents in Soil (plus field and laboratory QAQC)

First Characterization Event

\begin{tabular}{|c|c|c|c|c|c|}
\hline $\begin{array}{l}\text { Sample } \\
\text { Number }\end{array}$ & Analyte & Result & Units & Qualifier & Matri \\
\hline DT00028 & Cobalt & 5 & $\mathrm{mg} / \mathrm{kg}$ & B & Soil \\
\hline DT00028 & Copper & 8.4 & $\mathrm{mg} / \mathrm{kg}$ & & Soil \\
\hline DT00028 & Iron & 12100 & $\mathrm{mg} / \mathrm{kg}$ & & Soil \\
\hline DT00028 & Lead & 10.3 & $\mathrm{mg} / \mathrm{kg}$ & & Soil \\
\hline DT00028 & Magnesium & 4720 & $\mathrm{mg} / \mathrm{kg}$ & & Soil \\
\hline DT00028 & Manganese & 453 & $\mathrm{mg} / \mathrm{kg}$ & & Soil \\
\hline DT00028 & Mercury & 0.051 & $\mathrm{mg} / \mathrm{kg}$ & U & Soil \\
\hline DT00028 & Nickel & 8 & $\mathrm{mg} / \mathrm{kg}$ & B & Soil \\
\hline DT00028 & Potassium & 4430 & $\mathrm{mg} / \mathrm{kg}$ & & Soil \\
\hline DT00028 & Selenium & 0.34 & $\mathrm{mg} / \mathrm{kg}$ & $U$ & Soil \\
\hline DT00028 & Silver & 0.77 & $\mathrm{mg} / \mathrm{kg}$ & U & Soil \\
\hline DT00028 & Sodium & 598 & $\mathrm{mg} / \mathrm{kg}$ & B & Soil \\
\hline DT00028 & Thallium & 0.3 & $\mathrm{mg} / \mathrm{kg}$ & $\mathrm{U}$ & Soil \\
\hline DT00028 & Vanadium & 18.7 & $\mathrm{mg} / \mathrm{kg}$ & & Soil \\
\hline DT00028 & Zinc & 35.9 & $\mathrm{mg} / \mathrm{kg}$ & & Soil \\
\hline DT00032 & Aluminum & 8710 & $\mathrm{mg} / \mathrm{kg}$ & & Soil \\
\hline DT00032 & Antimony & 9.3 & $\mathrm{mg} / \mathrm{kg}$ & $U$ & Soil \\
\hline DT00032 & Arsenic & 2.8 & $\mathrm{mg} / \mathrm{kg}$ & & Soil \\
\hline DT00032 & Barium & 144 & $\mathrm{mg} / \mathrm{kg}$ & & Soil \\
\hline DT00032 & Beryllium & 0.66 & $\mathrm{mg} / \mathrm{kg}$ & B & Soil \\
\hline DT00032 & Cadmium & 0.75 & $\mathrm{mg} / \mathrm{kg}$ & $U$ & Soil \\
\hline DT00032 & Calcium & 15600 & $\mathrm{mg} / \mathrm{kg}$ & & Soil \\
\hline DT00032 & Chromium & 4.7 & $\mathrm{mg} / \mathrm{kg}$ & & Soil \\
\hline DT00032 & Cobalt & 3.7 & $\mathrm{mg} / \mathrm{kg}$ & B & Soil \\
\hline DT00032 & Copper & 9.6 & $\mathrm{mg} / \mathrm{kg}$ & & Soil \\
\hline DT00032 & Iron & 10100 & $\mathrm{mg} / \mathrm{kg}$ & & Soil \\
\hline DT00032 & Lead & 13.8 & $\mathrm{mg} / \mathrm{kg}$ & & Soil \\
\hline DT00032 & Magnesium & 3940 & $\mathrm{mg} / \mathrm{kg}$ & & Soil \\
\hline DT00032 & Manganese & 374 & $\mathrm{mg} / \mathrm{kg}$ & & Soil \\
\hline DT00032 & Mercury & 0.051 & $\mathrm{mg} / \mathrm{kg}$ & $U$ & Soil \\
\hline DT00032 & Nickel & 7 & $\mathrm{mg} / \mathrm{kg}$ & B & Soil \\
\hline DT00032 & Potassium & 4040 & $\mathrm{mg} / \mathrm{kg}$ & & Soil \\
\hline DT00032 & Selenium & 0.34 & $\mathrm{mg} / \mathrm{kg}$ & $\mathrm{U}$ & Soil \\
\hline DT00032 & Silver & 0.77 & $\mathrm{mg} / \mathrm{kg}$ & $\mathrm{U}$ & Soil \\
\hline DT00032 & Sodium & 479 & $\mathrm{mg} / \mathrm{kg}$ & B & Soil \\
\hline DT00032 & Thallium & 0.3 & $\mathrm{mg} / \mathrm{kg}$ & $\mathrm{U}$ & Soil \\
\hline DT00032 & Vanadium & 14.7 & $\mathrm{mg} / \mathrm{kg}$ & & Soil \\
\hline DT00032 & Zinc & 34.1 & $\mathrm{mg} / \mathrm{kg}$ & & Soil \\
\hline DT00049 & Aluminum & 10300 & $\mathrm{mg} / \mathrm{kg}$ & & Soil \\
\hline DT00049 & Antimony & 9.3 & $\mathrm{mg} / \mathrm{kg}$ & U & Soil \\
\hline DT00049 & Arsenic & 3 & $\mathrm{mg} / \mathrm{kg}$ & & Soil \\
\hline DT00049 & Barium & 167 & $\mathrm{mg} / \mathrm{kg}$ & & Soil \\
\hline DT00049 & Beryllium & 0.76 & $\mathrm{mg} / \mathrm{kg}$ & $B$ & Soil \\
\hline DT00049 & Cadmium & 0.75 & $\mathrm{mg} / \mathrm{kg}$ & U & Soil \\
\hline DT00049 & Calcium & 13300 & $\mathrm{mg} / \mathrm{kg}$ & & Soil \\
\hline DT00049 & Chromium & 6.3 & $\mathrm{mg} / \mathrm{kg}$ & & Soil \\
\hline DT00049 & Cobalt & 5.2 & $\mathrm{mg} / \mathrm{kg}$ & B & Soil \\
\hline DT00049 & Copper & 9 & $\mathrm{mg} / \mathrm{kg}$ & & Soil \\
\hline
\end{tabular}


Appendix C

Laboratory Results for Target Analyte List Constituents in Soil

(plus field and laboratory QA/QC)

First Characterization Event

\begin{tabular}{|c|c|c|c|c|c|}
\hline $\begin{array}{l}\text { Sample } \\
\text { Number }\end{array}$ & Analyte & Result & Units & Qualifier & Matrix \\
\hline DT00049 & Iron & 13500 & $\mathrm{mg} / \mathrm{kg}$ & & Soil \\
\hline DT00049 & Lead & 10.1 & $\mathrm{mg} / \mathrm{kg}$ & & Soil \\
\hline DT00049 & Magnesium & 4760 & $\mathrm{mg} / \mathrm{kg}$ & & Soil \\
\hline DT00049 & Manganese & 487 & $\mathrm{mg} / \mathrm{kg}$ & & Soil \\
\hline DT00049 & Mercury & 0.051 & $\mathrm{mg} / \mathrm{kg}$ & $U$ & Soil \\
\hline DT00049 & Nickel & 7.5 & $\mathrm{mg} / \mathrm{kg}$ & B & Soil \\
\hline DT00049 & Potassium & 4130 & $\mathrm{mg} / \mathrm{kg}$ & & Soil \\
\hline DT00049 & Selenium & 0.34 & $\mathrm{mg} / \mathrm{kg}$ & U & Soil \\
\hline DT00049 & Silver & 0.77 & $\mathrm{mg} / \mathrm{kg}$ & $U$ & Soil \\
\hline DT00049 & Sodium & 523 & $\mathrm{mg} / \mathrm{kg}$ & B & Soil \\
\hline DT00049 & Thallium & 0.3 & $\mathrm{mg} / \mathrm{kg}$ & $U$ & Soil \\
\hline DT00049 & Vanadium & 20.8 & $\mathrm{mg} / \mathrm{kg}$ & & Soil \\
\hline DT00049 & Zinc & 38.6 & $\mathrm{mg} / \mathrm{kg}$ & & Soil \\
\hline DT00036 & Arsenic & 0.011 & $\mathrm{mg} / \mathrm{l}$ & & TCLP \\
\hline DT00036 & Barium & 0.45 & $\mathrm{mg} / \mathrm{l}$ & & TCLP \\
\hline DT00036 & Cadmium & 0.005 & $\mathrm{mg} / \mathrm{l}$ & $\mathbf{U}$ & TCLP \\
\hline DT00036 & Chromium & 0.02 & $\mathrm{mg} / \mathrm{l}$ & $\mathbf{U}$ & TCLP \\
\hline DT00036 & Lead & 0.008 & $\mathrm{mg} / \mathrm{l}$ & & TCLP \\
\hline DT00036 & Mercury & 0.002 & $\mathrm{mg} / \mathrm{l}$ & $\mathrm{U}$ & TCLP \\
\hline DT00036 & Selenium & 0.007 & $\mathrm{mg} / \mathrm{l}$ & & TCLP \\
\hline DT00036 & Silver & 0.01 & $\mathrm{mg} / \mathrm{l}$ & $u$ & TCLP \\
\hline DT00040 & Arsenic & 0.004 & $\mathrm{mg} / \mathrm{l}$ & & TCLP \\
\hline DT00040 & Barium & 0.2 & $\mathrm{mg} / \mathrm{l}$ & $\mathrm{U}$ & TCLP \\
\hline DT00040 & Cadmium & 0.005 & $\mathrm{mg} / \mathrm{l}$ & $U$ & TCLP \\
\hline DT00040 & Chromium & 0.02 & $\mathrm{mg} / \mathrm{l}$ & $\mathrm{U}$ & TCLP \\
\hline DTO0040 & Lead & 0.003 & $\mathrm{mg} / \mathrm{l}$ & $\mathbf{U}$ & TCLP \\
\hline DT00040 & Mercury & 0.002 & $\mathrm{mg} / \mathrm{l}$ & $\mathrm{U}$ & TCLP \\
\hline DT00040 & Selenium & 0.004 & $\mathrm{mg} / \mathrm{l}$ & & TCLP \\
\hline DT00040 & Silver & 0.01 & $\mathrm{mg} / \mathrm{l}$ & U & TCLP \\
\hline DT00045 & Arsenic & 0.014 & $\mathrm{mg} / \mathrm{l}$ & & TCLP \\
\hline DT00045 & Barium & 0.42 & $\mathrm{mg} / \mathrm{l}$ & & TCLP \\
\hline DT00045 & Cadmium & 0.005 & $\mathrm{mg} / \mathrm{l}$ & $\mathrm{U}$ & TCLP \\
\hline DTO0045 & Chromium & 0.02 & $\mathrm{mg} / \mathrm{l}$ & $\mathrm{U}$ & TCLP \\
\hline DT00045 & Lead & 0.003 & $\mathrm{mg} / \mathrm{l}$ & $\mathrm{U}$ & TCLP \\
\hline DT00045 & Mercury & 0.002 & $\mathrm{mg} / \mathrm{l}$ & $U$ & TCLP \\
\hline DT00045 & Selenium & 0.006 & $\mathrm{mg} / \mathrm{l}$ & & TCLP \\
\hline DT00045 & Silver & 0.01 & $\mathrm{mg} / \mathrm{l}$ & $\mathbf{U}$ & TCLP \\
\hline DT00001 & Aluminum & 29.8 & $u g / 1$ & B & Field Rinsate \\
\hline DT00001 & Antimony & 46.2 & ug/l & $\mathrm{U}$ & Field Rinsate \\
\hline DT00001 & Arsenic & 1.8 & $u g / /$ & $\mathbf{U}$ & Field Rinsate \\
\hline DT00001 & Barium & 1.7 & $\mathrm{ug} / \mathrm{l}$ & B & Field Rinsate \\
\hline DT00001 & Beryllium & 0.53 & $u g / 1$ & B & Field Rinsate \\
\hline DT00001 & Cadmium & 3.7 & $u g / 1$ & u & Field Rinsate \\
\hline DT00001 & Calcium & 267 & $u g /$ & B & Field Rinsate \\
\hline DT00001 & Chromium & 5.3 & ug/l & U & Field Rinsate \\
\hline DT00001 & Cobalt & 3.4 & $u g / 1$ & $\mathrm{U}$ & Field Rinsate \\
\hline DT00001 & Copper & 10.5 & $\mathrm{ug} / \mathrm{l}$ & B & Field Rinsate \\
\hline DT00001 & Iron & 302 & $\mathrm{ug} / \mathrm{l}$ & & Field Rinsate \\
\hline
\end{tabular}


Appendix C

Laboratory Results for Target Analyte List Constituents in Soil

(plus field and laboratory QAQC)

First Characterization Event

Sample

Number

DT00001

DT00001

DTO0001

DT00001

DT00001

DT00001

DTO0001

DT00001

DT00001

DT00001

DTO0001

DTO0001

DT00053

DTO0053

DT00053

DT00053

DT00053

DT00053

DT00053

DTO0053

DT00053

DT00053

DT00053

DT00053

DT00053

DT00053

DT00053

DT00053

DT00053

DT00053

DT00053

DT00053

DT00053

DT00053

DT00053

DT00054

DTO0054

DT00054

DT00054

DTO0054

DT00054

DTO0054

DT00054

DT00054

DT00054

DT00054

DT00054

DT00054
Analyte

Lead

Magnesium

Manganese

Mercury

Nickel

Potassium

Selenium

Silver

Sodium

Thallium

Vanadium

Zinc

Aluminum

Antimony

Arsenic

Barium

Beryllium

Cadmium

Calcium

Chromium

Cobalt

Copper

Iron

Lead

Magnesium

Manganese

Mercury

Nickel

Potassium

Selenium

Silver

Sodium

Thallium

Vanadium

Zinc

Aluminum

Antimony

Arsenic

Barium

Beryllium

Cadmium

Calcium

Chromium

Cobalt

Copper

Iron

Lead

Magnesium
Result

1
179

2.4

0.1

15.5

1940

1.7

3.8

142

1.7

9.6

10.2

29

46.2

1.8

0.68

3.7

179

5.3

3.4

12

51

1

168

1.9

0.1

15.5

1940

1.7

3.8

151

1.7

9.6

19.8

39.6

46.2

1.8

1

0.67

3.7

164

5.3

3.4

12.7

46.6

197
Units

ug/

ug/l

ug/

ug/l

ug/

ug/

ug/

ug/

ug/I

ug/

ug/l

ug/I

ug/l

ug/

ug/l

ug/

$u g / l$

ug/l

ug/l

ug/

ug/l

ug/

ug/l

ug/

ug/l

ug/

ug/l

ug/l

ug/l

ug/I

ug/I

ug/l

ug/l

ug/l

ug/l

ug/l

ug/I

ug/l

ug/l

ugl

ug/l

ug/l

ug/

ug/

ug/l

ug/l

$u g / /$

ug/l
Qualifier Matrix

$U$ Field Rinsate

B Field Rinsate

B Field Rinsate

U Field Rinsate

$U$ Field Rinsate

$U$ Field Rinsate

$U$ Field Rinsate

$U$ Field Rinsate

B Field Rinsate

B Field Rinsate

U Fieid Rinsate

B Field Rinsate

U Field Rinsate

$U$ Field Rinsate

$U$ Field Rinsate

$U$ Field Rinsate

B Field Rinsate

U Field Rinsate

B Field Rinsate

U Field Rinsate

$U$ Field Rinsate

B Field Rinsate

B Field Rinsate

U Field Rinsate

B Field Rinsate

B Field Rinsate

U Field Rinsate

$U$ Field Rinsate

U Field Rinsate

U Field Rinsate

$U$ Field Rinsate

B Field Rinsate

B Field Rinsate

U Field Rinsate

B Field Rinsate

B Field Rinsate

U Field Rinsate

U Field Rinsate

$U$ Field Rinsate

B Field Rinsate

$U$ Field Rinsate

B Field Rinsate

U Field Rinsate

$U$ Field Rinsate

B Field Rinsate

B Field Rinsate

U Field Rinsate

B Field Rinsate 
Appendix C

Laboratory Results for Target Analyte List Constituents in Soil

(plus field and laboratory QAQQC)

First Characterization Event

\begin{tabular}{|c|c|c|c|c|c|}
\hline $\begin{array}{l}\text { Sample } \\
\text { Number }\end{array}$ & Analyte & Result & Units & Qualifier & Matrix \\
\hline DTO0054 & Manganese & 1.9 & $u g h$ & B & Field Rinsate \\
\hline DT00054 & Mercury & 0.1 & ug/ & U & Field Rinsate \\
\hline DT00054 & Nickel & 15.5 & $u g / 1$ & $\mathbf{U}$ & Field Rinsate \\
\hline DT00054 & Potassium & 1940 & $u g A$ & $\mathbf{U}$ & Field Rinsate \\
\hline DT00054 & Selenium & 1.7 & $u g / 1$ & U & Field Rinsate \\
\hline DT00054 & Silver & 4.4 & $u g / 1$ & B & Field Rinsate \\
\hline DT00054 & Sodium & 46.6 & ug/l & $\mathrm{B}$ & Field Rinsate \\
\hline DT00054 & Thallium & 1.5 & $u g / 1$ & $\mathbf{U}$ & Field Rinsate \\
\hline DT00054 & Vanadium & 9.6 & ug/ & $\mathrm{U}$ & Field Rinsate \\
\hline DT00054 & Zinc & 107 & $u g / 1$ & & Field Rinsate \\
\hline DT00002 MS & Antimony & 69 & $\%$ Recovery & & Lab Matrix Spike \\
\hline DT00002 MS & Arsenic & 90 & $\%$ Recovery & & Lab Matrix Spike \\
\hline DT00002 MS & Barium & 106 & $\%$ Recovery & & Lab Matrix Spike \\
\hline DT00002 MS & Beryllium & 109 & $\%$ Recovery & & Lab Matrix Spike \\
\hline DT00002 MS & Cadmium & 112 & $\%$ Recovery & & Lab Matrix Spike \\
\hline DT00002 MS & Chromium & 107 & $\%$ Recovery & & Lab Matrix Spike \\
\hline DT00002 MS & Cobalt & 106 & $\%$ Recovery & & Lab Matrix Spike \\
\hline DT00002 MS & Copper & 110 & $\%$ Recovery & & Lab Matrix Spike \\
\hline DT00002 MS & Lead & 36 & $\%$ Recovery & & Lab Matrix Spike \\
\hline DT00002 MS & Manganese & 60 & $\%$ Recovery & & Lab Matrix Spike \\
\hline DT00002 MS & Mercury & 117 & $\%$ Recovery & & Lab Matrix Spike \\
\hline DT00002 MS & Nickel & 109 & $\%$ Recovery & & - Lab Matrix Spike \\
\hline DTO0002 MS & Selenium & 88 & $\%$ Recovery & & Lab Matrix Spike \\
\hline DT00002 MS & Silver & 100 & $\%$ Recovery & & Lab Matrix Spike \\
\hline DT00002 MS & Thallium & 26 & $\%$ Recovery & & Lab Matrix Spike \\
\hline DT00002 MS & Vanadium & 109 & $\%$ Recovery & & Lab Matrix Spike \\
\hline DT00002 MS & Zinc & 113 & $\%$ Recovery & & Lab Matrix Spike \\
\hline DT00036 MS & Arsenic & 100 & $\%$ Recovery & & Lab Matrix Spike \\
\hline DT00036 MS & Barium & 89 & $\%$ Recovery & & Lab Matrix Spike \\
\hline DT00036 MS & Cadmium & 93 & $\%$ Recovery & & Lab Matrix Spike \\
\hline DT00036 MS & Chromium & 94 & $\%$ Recovery & & Lab Matrix Spike \\
\hline DT00036 MS & Lead & 88 & $\%$ Recovery & & Lab Matrix Spike \\
\hline DT00036 MS & Mercury & 48 & $\%$ Recovery & & Lab Matrix Spike \\
\hline DT00036 MS & Selenium & 97 & $\%$ Recovery & & Lab Matrix Spike \\
\hline DT00036 MS & Silver & 70 & $\%$ Recovery & & Lab Matrix Spike \\
\hline
\end{tabular}

Qualifiers

$U$ - Analyte was analyzed for but not detected

B - Reported value was obtained from a reading that was less than ther required detection limit but greater than the intrument detection limit.

Dup - Duplicate sample

milligram/kilogram (mg/kg) or parts per million (ppm)

microgram/kilogram (ug/kg) or parts per billion (ppb) 
Appendix $\mathrm{C}$

Isotopic Laboratory Analytical Results in Soil

Sample Number

DTO0002

DT00002

DT00002

DT00002

DT00002

DT00002

DT00002

DT00002

DTO0002

DT00002

DT00002

DT00002

DTO0002

DT00002

DT00002

DT00002

DT00002

DT00002

DT00002

DT00002

DT00002

DT00002

DT00002

DT00002

DT00002

DT00002

DT00002

DT00002

DT00002 DUP

DT00002 DUP

DT00002 DUP

DT00002 DUP

DT00002 DUP

DT00002 DUP

DT00002 DUP

DT00002 DUP

DT00002 DUP

DT00002 DUP

DT00002 DUP

DT00002 DUP

DT00002 DUP

DT00002 DUP

DT00002 DUP

DT00002 DUP

DT00002 DUP

DT00002 DUP

DT00002 DUP

DT00002 DUP

DT00002 DUP

DT00002 DUP
Isotope

Actinium 227

Americium 241

Americium 241

Antimony 125

Barium-133

Bismuth 214

Cesium 137

Cobalt 60

Europium 152

Europium 154

Europium 155

Lead 210

Lead 212

Plutonium 238

Plutonium 239/240

Potassium 40

Protactinium-231

Protactinium-234

Radium-223

Radium-226

Thallium 208

Thorium-232

Uranium 234

Uranium 235/236

Uranium 238

Uranium-234

Uranium-235

Uranium-238

Actinium 227

Americium 241

Americium 241

Antimony 125

Barium-133

Bismuth 214

Cesium 137

Cobalt 60

Europium 152

Europium 154

Europium 155

Lead 210

Lead 212

Plutonium 238

Plutonium 239/240

Potassium 40

Protactinium-231

Protactinium-234

Radium-223

Radium-226

Thallium 208

Thorium-232
First Characterization Event

\begin{tabular}{|c|c|c|c|}
\hline $\begin{array}{l}\text { Result } \\
\text { ND }\end{array}$ & $\begin{array}{l}\text { Units } \\
\mathrm{pCi} / \mathrm{g}\end{array}$ & 2 Sigma & $\begin{array}{l}\text { Analytical Method } \\
\text { Gamma Spec }\end{array}$ \\
\hline 0.056 & $\mathrm{pCi} / \mathrm{g}$ & 0.021 & 1 NAS-NS-3006 \\
\hline ND & $\mathrm{pCi} / \mathrm{g}$ & & Gamma Spec \\
\hline ND & $\mathrm{pCi} / \mathrm{g}$ & & Gamma Spec \\
\hline ND & $\mathrm{pCi} / \mathrm{g}$ & & Gamma Spec \\
\hline
\end{tabular}

0.14 Gamma Spec

0.08 Gamma Spec

Gamma Spec

Gamma Spec

Gamma Spec

0.07 Gamma Spec

0.55 Gamma Spec

0.23 Gamma Spec

0.011 NAS-NA-3058

0.04 NAS-NA-3058

3.6 Gamma Spec

Gamma Spec

Gamma Spec

Gamma Spec

0.09 Gamma Spec

0.07 Gamma Spec

0.2 Gamma Spec

0.2 NAS-NA-3050

0.046 NAS-NA-3050

0.18 NAS-NA-3050

0.54 Gamma Spec

Gamma Spec

0.54 Gamma Spec

0.34 Gamma Spec

0.012 NAS-NS-3006

Gamma Spec

Gamma Spec

Gamma Spec

0.14 Gamma Spec

0.08 Gamma Spec.

Gamma Spec

Gamma Spec

Gamma Spec

Gamma Spec

Gamma Spec

0.22 Gamma Spec

0.01 NAS-NA-3058

0.035 NAS-NA-3058

3.8 Gamma Spec

Gamma Spec

Gamma Spec

Gamma Spec

0.1 Gamma Spec

0.08 Gamma Spec

0.23 Gamma Spec 
Appendix C

Isotopic Laboratory Analytical Results in Soil

First Characterization Event

\begin{tabular}{|c|c|c|c|c|c|}
\hline $\begin{array}{l}\text { Sample Number } \\
\text { DT00002 DUP }\end{array}$ & $\begin{array}{l}\text { Isotope } \\
\text { Uranium } 234\end{array}$ & $\begin{array}{r}\text { Result } \\
0.82\end{array}$ & $\begin{array}{l}\text { Units } \\
\mathrm{pCi} / \mathrm{g}\end{array}$ & $\begin{array}{r}2 \text { Sigma } \\
0.18\end{array}$ & $\begin{array}{l}\text { Analytical Method } \\
3 \text { NAS-NA-3050 }\end{array}$ \\
\hline DT00002 DUP & Uranium 235/236 & 0.043 & $\mathrm{pCi} / \mathrm{g}$ & 0.034 & NAS-NA-3050 \\
\hline DT00002 DUP & Uranium 238 & 0.51 & $\mathrm{pCi} / \mathrm{g}$ & 0.13 & 3 NAS-NA-3050 \\
\hline DT00002 DUP & Uranium-234 & 1.96 & $\mathrm{pCi} / \mathrm{g}$ & 0.88 & Gamma Spec \\
\hline DT00002 DUP & Uranium-235 & ND & $\mathrm{pCi} / \mathrm{g}$ & & Gamma Spec \\
\hline DT00002 DUP & Uranium-238 & 1.96 & $\mathrm{pCi} / \mathrm{g}$ & 0.88 & Gamma Spec \\
\hline DT00003 & Americium 241 & 0.024 & $\mathrm{pCi} / \mathrm{g}$ & 0.014 & NAS-NS-3006 \\
\hline DT00003 & Plutonium 238 & 0.003 & $\mathrm{pCi} / \mathrm{g}$ & 0.007 & NAS-NA-3058 \\
\hline DT00003 & Plutonium 239/240 & 0.066 & $\mathrm{pCi} / \mathrm{g}$ & 0.032 & NAS-NA-3058 \\
\hline DT00003 & Uranium 234 & 1.03 & $\mathrm{pCi} / \mathrm{g}$ & 0.21 & NAS-NA-3050 \\
\hline DT00003 & Uranium 235/236 & 0.077 & $\mathrm{pCi} / \mathrm{g}$ & 0.045 & NAS-NA-3050 \\
\hline DT00003 & Uranium 238 & 1.06 & $\mathrm{pCi} / \mathrm{g}$ & 0.22 & NAS-NA-3050 \\
\hline DT00004 & Americium 241 & 0.011 & $\mathrm{pCi} / \mathrm{g}$ & 0.008 & 3 NAS-NS-3006 \\
\hline DT00004 & Plutonium 238 & -0.008 & $\mathrm{pCi} / \mathrm{g}$ & 0.005 & NAS-NA-3058 \\
\hline DT00004 & Plutonium 239/240 & 0.1 & $\mathrm{pCi} / \mathrm{g}$ & 0.43 & 3 NAS-NA-3058 \\
\hline DT00004 & Uranium 234 & 1.18 & $\mathrm{pCi} / \mathrm{g}$ & 0.24 & + NAS-NA-3050 \\
\hline DT00004 & Uranium 235/236 & 0.07 & $\mathrm{pCi} / \mathrm{g}$ & 0.046 & NAS-NA-3050 \\
\hline DT00004 & Uranium 238 & 1.05 & $\mathrm{pCi} / \mathrm{g}$ & 0.22 & NAS-NA-3050 \\
\hline DTT00006 & Actinium 227 & ND & $\mathrm{pCi} / \mathrm{g}$ & & Gamma Spec \\
\hline DTं00006 & Americium 241 & 0.28 & $\mathrm{pCi} / \mathrm{g}$ & 0.15 & 5 NAS-NS-3006 \\
\hline DT00006 & Americium 241 & 1.82 & $\mathrm{pCi} / \mathrm{g}$ & 0.21 & Gamma Spec \\
\hline DT00006 & Antimony 125 & ND & $\mathrm{pCi} / \mathrm{g}$ & & Gamma Spec \\
\hline DT00006 & Barium-133 & ND & $\mathrm{pCi} / \mathrm{g}$ & & Gamma Spec \\
\hline DT00006 & Bismuth 214 & 1.16 & $\mathrm{pCi} / \mathrm{g}$ & 0.13 & 3 Gamma Spec \\
\hline DT00006 & Cesium 137 & 1.06 & $\mathrm{pCi} / \mathrm{g}$ & 0.13 & 3 Gamma Spec \\
\hline DT00006 & Cobalt 60 & ND & $\mathrm{pCi} / \mathrm{g}$ & & Gamma Spec \\
\hline DT00006 & Europium 152 & ND & $\mathrm{pCi} / \mathrm{g}$ & & Gamma Spec \\
\hline DT00006 & Europium 154 & ND & $\mathrm{pCi} / \mathrm{g}$ & & Gamma Spec \\
\hline DT00006 & Europium 155 & 0.13 & $\mathrm{pCi} / \mathrm{g}$ & 0.07 & 7 Gamma Spec \\
\hline DT00006 & Lead 210 & 1.77 & $\mathrm{pCi} / \mathrm{g}$ & 0.58 & 3 Gamma Spec \\
\hline DT00006 & Lead 212 & 1.77 & $\mathrm{pCi} / \mathrm{g}$ & 0.15 & 5 Gamma Spec \\
\hline DT00006 & Plutonium 238 & 0.15 & pCi/g & 0.06 & 5 NAS-NA-3058 \\
\hline DT00006 & Plutonium 239/240 & 6.92 & $\mathrm{pCi} / \mathrm{g}$ & 1.16 & 6 NAS-NA-3058 \\
\hline DT00006 & Potassium 40 & 29.6 & $\mathrm{pCi} / \mathrm{g}$ & 3.1 & Gamma Spec \\
\hline DT00006 & Protactinium-231 & ND & $\mathrm{pCi} / \mathrm{g}$ & & Gamma Spec \\
\hline DT00006 & Protactinium-234 & ND & $\mathrm{pCi} / \mathrm{g}$ & & Gamma Spec \\
\hline DT00006 & Radium-223 & ND & $\mathrm{pCi} / \mathrm{g}$ & & Gamma Spec \\
\hline DT00006 & Radium-226 & 1.24 & $\mathrm{pCi} / \mathrm{g}$ & 0.09 & Gamma Spec \\
\hline DT00006 & Thallium 208 & 0.58 & $\mathrm{pCi} / \mathrm{g}$ & 0.07 & 7 Gamma Spec \\
\hline DT00006 & Thorium-232 & 1.68 & $\mathrm{pCi} / \mathrm{g}$ & 0.2 & 2 Gamma Spec \\
\hline DT00006 & Uranium 234 & 1.11 & pCi/g & 0.26 & 5 NAS-NA-3050 \\
\hline DT00006 & Uranium 235/236 & 0.049 & $\mathrm{pCi} / \mathrm{g}$ & 0.044 & 4 NAS-NA-3050 \\
\hline DT00006 & Uranium 238 & 0.92 & $\mathrm{pCi} / \mathrm{g}$ & 0.23 & 3 NAS-NA-3050 \\
\hline DT00006 & Uranium-234 & 1.1 & $\mathrm{pCi} / \mathrm{g}$ & 0.5 & 5 Gamma Spec \\
\hline DT00006 & Uranium-235 & ND & $\mathrm{pCi} / \mathrm{g}$ & & Gamma Spec \\
\hline DT00006 & Uranium-238 & 1.1 & $\mathrm{pCi} / \mathrm{g}$ & 0.5 & 5 Gamma Spec \\
\hline DT00006 RE & Americium 241 & 0.3 & $\mathrm{pCi} / \mathrm{g}$ & 0.08 & 3 NAS-NS-3006 \\
\hline DT00006 RE & Plutonium 238 & 0.065 & $\mathrm{pCi} / \mathrm{g}$ & 0.022 & NAS-NS-3058 \\
\hline DT00006 RE & Plutonium 239/240 & 7.08 & $\mathrm{pCi} / \mathrm{g}$ & 1.16 & NAS-NS-3058 \\
\hline DTO0007 & Americium 241 & 0.21 & $\mathrm{pCi} / \mathrm{g}$ & 0.05 & 5 NAS-NS-3006 \\
\hline
\end{tabular}


Appendix C

Isotopic Laboratory Analytical Results in Soil

Sample Number

DT00007

DT00007

DT00007

DT00007

DT00007

DT00008

DT00008

DT00008

DT00008

DT00008

DT00008

DT00010

DT00010

DT00010

DT00010

DT00010

DT00010

DT00010

DTO0010

DTO0010

DT00010

DT00010

DT00010

DT00010

DT00010

DT00010

DT00010

DT00010

DT00010

DT00010

DT00010

DT00010

DT00010

DT00010

DT00010

DT00010

DT00010

DT00010

DT00010

DT00011

DT00011

DT00011

DT00011

DT00011

DT00011

DT00012

DT00012

DT00012

DT00012

DT00012
Isotope

Plutonium 238

Plutonium 239/240

Uranium 234

Uranium 235/236

Uranium 238

Americium 241

Plutonium 238

Plutonium 239/240

Uranium 234

Uranium 235/236

Uranium 238

Actinium 227

Americium 241

Americium 241

Antimony 125

Barium-133

Bismuth 214

Cesium 137

Cobalt 60

Europium 152

Europium 154

Europium 155

Lead 210

Lead 212

Plutonium 238

Plutonium 239/240

Potassium 40

Protactinium-231

Protactinium-234

Radium-223

Radium-226

Thallium 208

Thorium-232

Uranium 234

Uranium 235/236

Uranium 238

Uranium-234

Uranium-235

Uranium-238

Americium 241

Plutonium 238

Plutonium 239/240

Uranium 234

Uranium 235/236

Uranium 238

Americium 241

Plutonium 238

Plutonium 239/240

Uranium 234

Uranium 235/236
First Characterization Event

$\begin{array}{rrr}\text { Result } & \text { Units } & \text { 2 Sigma Analytical Method } \\ 0.012 & \mathrm{pCi} / \mathrm{g} & 0.015 \text { NAS-NA-3058 } \\ 1.15 & \mathrm{pCi} / \mathrm{g} & 0.21 \text { NAS-NA-3058 } \\ 0.97 & \mathrm{pCi} / \mathrm{g} & 0.2 \text { NAS-NA-3050 } \\ 0.13 & \mathrm{pCi} / \mathrm{g} & 0.06 \text { NAS-NA-3050 } \\ 0.85 & \mathrm{pCi} / \mathrm{g} & 0.18 \text { NAS-NA-3050 } \\ 0.001 & \mathrm{pCi} / \mathrm{g} & 0.003 \text { NAS-NS-3006 } \\ 0.001 & \mathrm{pCi} / \mathrm{g} & 0.007 \text { NAS-NA-3058 } \\ 0.02 & \mathrm{pCi} / \mathrm{g} & 0.018 \text { NAS-NA-3058 } \\ 1.16 & \mathrm{pCi} / \mathrm{g} & 0.25 \text { NAS-NA-3050 } \\ 0.079 & \mathrm{pCi} / \mathrm{g} & 0.05 \text { NAS-NA-3050 } \\ 0.95 & \mathrm{pCi} / \mathrm{g} & 0.21 \text { NAS-NA-3050 } \\ 2.31 & \mathrm{pCi} / \mathrm{g} & 0.44 \text { Gamma Spec } \\ 0.089 & \mathrm{pCi} / \mathrm{g} & 0.036 \text { NAS-NS-3006 } \\ \mathrm{ND} & \mathrm{pCi} / \mathrm{g} & \text { Gamma Spec } \\ \mathrm{ND} & \mathrm{pCi} / \mathrm{g} & \text { Gamma Spec } \\ \mathrm{ND} & \mathrm{pCi} / \mathrm{g} & \text { Gamma Spec }\end{array}$

0.16 Gamma Spec

0.16 Gamma Spec

Gamma Spec

Gamma Spec

Gamma Spec

Gamma Spec

Gamma Spec

0.2 Gamma Spec

0.01 NAS-NA-3058

0.13 NAS-NA-3058

3.4 Gamma Spec

Gamma Spec

Gamma Spec

Gamma Spec

0.11 Gamma Spec

0.09 Gamma Spec

0.22 Gamma Spec

0.27 NAS-NA-3050

0.059 NAS-NA-3050

0.26 NAS-NA-3050

1.11 Gamma Spec

Gamma Spec

1.11 Gamma Spec

0.018 NAS-NS-3006

0.021 NAS-NA-3058

0.05 NAS-NA-3058

0.25 NAS-NA-3050

0.043 NAS-NA-3050

0.21 NAS-NA-3050

0.012 NAS-NS-3006

0.035 NAS-NA-3058

0.22 NAS-NA-3058

0.23 NAS-NA-3050

0.055 NAS-NA-3050 
Appendix C

Isotopic Laboratory Analytical Results in Soil

First Characterization Event

\begin{tabular}{|c|c|c|c|c|c|}
\hline Sample Number & Isotope & Result & Units & 2 Sigma & Analytical Method \\
\hline DT00012 & Uranium 238 & 1.07 & $\mathrm{pCi} / \mathrm{g}$ & 0.25 & 5 NAS-NA-3050 \\
\hline DTO0014 & Actinium 227 & ND & $\mathrm{pCi} / \mathrm{g}$ & & Gamma Spec \\
\hline DT00014 & Americium 241 & 0.009 & $\mathrm{pCi} / \mathrm{g}$ & 0.011 & 1 NAS-NS-3006 \\
\hline DT00014 & Americium 241 & 0.58 & $\mathrm{pCi} / \mathrm{g}$ & 0.08 & 3 Gamma Spec \\
\hline DT00014 & Antimony 125 & ND & $\mathrm{pCi} / \mathrm{g}$ & & Gamma Spec \\
\hline DT00014 & Barium-133 & ND & $\mathrm{pCi} / \mathrm{g}$ & & Gamma Spec \\
\hline DT00014 & Bismuth 214 & 1.24 & $\mathrm{pCi} / \mathrm{g}$ & 0.12 & 2 Gamma Spec \\
\hline DTO0014 & Cesium 137 & 1.34 & $\mathrm{pCi} / \mathrm{g}$ & 0.15 & 5 Gamma Spec \\
\hline DT00014 & Cobalt 60 & 0.061 & $\mathrm{pCi} / \mathrm{g}$ & 0.031 & Gamma Spec \\
\hline DT00014 & Europium 152 & ND & $\mathrm{pCi} / \mathrm{g}$ & & Gamma Spec \\
\hline DT00014 & Europium 154 & ND & $\mathrm{pCi} / \mathrm{g}$ & & Gamma Spec \\
\hline DT00014 & Europium 155 & ND & $\mathrm{pCi} / \mathrm{g}$ & & Gamma Spec \\
\hline DT00014 & Lead 210 & 1.66 & $\mathrm{pCi} / \mathrm{g}$ & 0.48 & 3 Gamma Spec \\
\hline DT00014 & Lead 212 & 1.77 & $\mathrm{pCi} / \mathrm{g}$ & 0.2 & 2 Gamma Spec \\
\hline DT00014 & Plutonium 238 & -0.004 & $\mathrm{pCi} / \mathrm{g}$ & 0.004 & 4 NAS-NA-3058 \\
\hline DT00014 & Plutonium 239/240 & 0.066 & $\mathrm{pCi} / \mathrm{g}$ & 0.19 & 9 NAS-NA-3058 \\
\hline DT00014 & Potassium 40 & 31.9 & $\mathrm{pCi} / \mathrm{g}$ & 3.3 & 3 Gamma Spec \\
\hline DT00014 & Protactinium-231 & ND & $\mathrm{pCi} / \mathrm{g}$ & & Gamma Spec \\
\hline DT00014 & Protactinium-234 & ND & $\mathrm{pCi} / \mathrm{g}$ & & Gamma Spec \\
\hline DT00014 & Radium-223 & ND & $\mathrm{pCi} / \mathrm{g}$ & & Gamma Spec \\
\hline DT00014 & Radium-226 & 1.19 & $\mathrm{pCi} / \mathrm{g}$ & 0.08 & 3 Gamma Spec \\
\hline DT00014 & Thallium 208 & 0.6 & $\mathrm{pCi} / \mathrm{g}$ & 0.06 & Gamma Spec \\
\hline DTO0014 & Thorium-232 & 1.63 & $\mathrm{pCi} / \mathrm{g}$ & 0.17 & 7 Gamma Spec \\
\hline DT00014 & Uranium 234 & 0.94 & $\mathrm{pCi} / \mathrm{g}$ & 0.29 & 9 NAS-NA-3050 \\
\hline DT00014 & Uranium 235/236 & 0.11 & $\mathrm{pCi} / \mathrm{g}$ & 0.09 & 9 NAS-NA-3050 \\
\hline DT00014 & Uranium 238 & 1.28 & $\mathrm{pCi} / \mathrm{g}$ & 0.36 & 6 NAS-NA-3050 \\
\hline DT00014 & Uranium-234 & 0.89 & $\mathrm{pCi} / \mathrm{g}$ & 0.44 & 4 Gamma Spec \\
\hline DT00014 & Uranium-235 & ND & $\mathrm{pCi} / \mathrm{g}$ & & Gamma Spec \\
\hline DT00014 & Uranium-238 & 0.89 & $\mathrm{pCi} / \mathrm{g}$ & 0.44 & 4 Gamma Spec \\
\hline DT00015 & Americium 241 & 0.085 & $\mathrm{pCi} / \mathrm{g}$ & 0.067 & 7 NAS-NS-3006 \\
\hline DT00015 & Plutonium 238 & -0.007 & $\mathrm{pCi} / \mathrm{g}$ & 0.005 & 5 NAS-NA-3058 \\
\hline DT00015 & Plutonium 239/240 & 0.017 & $\mathrm{pCi} / \mathrm{g}$ & 0.029 & 9 NAS-NA-3058 \\
\hline DT00015 & Uranium 234 & 1.45 & $\mathrm{pCi} / \mathrm{g}$ & 0.4 & 4 NAS-NA-3050 \\
\hline DT00015 & Uranium 235/236 & 0.25 & $\mathrm{pCi} / \mathrm{g}$ & 0.15 & 5 NAS-NA-3050 \\
\hline DT00015 & Uranium 238 & 1.05 & $\mathrm{pCi} / \mathrm{g}$ & 0.32 & 2 NAS-NA-3050 \\
\hline DT00016 & Americium 241 & 0.087 & $\mathrm{pCi} / \mathrm{g}$ & 0.04 & 4 NAS-NS-3006 \\
\hline DT00016 & Plutonium 238 & 0.003 & $\mathrm{pCi} / \mathrm{g}$ & 0.014 & 4 NAS-NA-3058 \\
\hline DT00016 & Plutonium 239/240 & 0.024 & $\mathrm{pCi} / \mathrm{g}$ & 0.027 & 7 NAS-NA-3058 \\
\hline DT00016 & Uranium 234 & 2.23 & $\mathrm{pCi} / \mathrm{g}$ & 0.54 & 4 NAS-NA-3050 \\
\hline DT00016 & Uranium 235/236 & 0.3 & $\mathrm{pCi} / \mathrm{g}$ & 0.16 & 6 NAS-NA-3050 \\
\hline DT00016 & Uranium 238 & 2.51 & $\mathrm{pCi} / \mathrm{g}$ & 0.59 & 9 NAS-NA-3050 \\
\hline DT00018 & Actinium 227 & ND & $\mathrm{pCi} / \mathrm{g}$ & & Gamma Spec \\
\hline DT00018 & Americium 241 & 0.009 & $\mathrm{pCi} / \mathrm{g}$ & 0.018 & 8 NAS-NS-3006 \\
\hline DT00018 & Americium 241 & ND & $\mathrm{pCi} / \mathrm{g}$ & & Gamma Spec \\
\hline DT00018 & Antimony 125 & ND & $\mathrm{pCi} / \mathrm{g}$ & & Gamma Spec \\
\hline DT00018 & Barium-133 & ND & $\mathrm{pCi} / \mathrm{g}$ & & Gamma Spec \\
\hline DT00018 & Bismuth 214 & 0.06 & $\mathrm{pCi} / \mathrm{g}$ & 0.027 & 7 Gamma Spec \\
\hline DT00018 & Cesium 137 & ND & $\mathrm{pCi} / \mathrm{g}$ & & Gamma Spec \\
\hline DT00018 & Cobalt 60 & ND & $\mathrm{pCi} / \mathrm{g}$ & & Gamma Spec \\
\hline DT00018 & Europium 152 & ND & $\mathrm{pCi} / \mathrm{g}$ & & Gamma Spec \\
\hline
\end{tabular}


Appendix C

Isotopic Laboratory Analytical Results in Soil

First Characterization Event

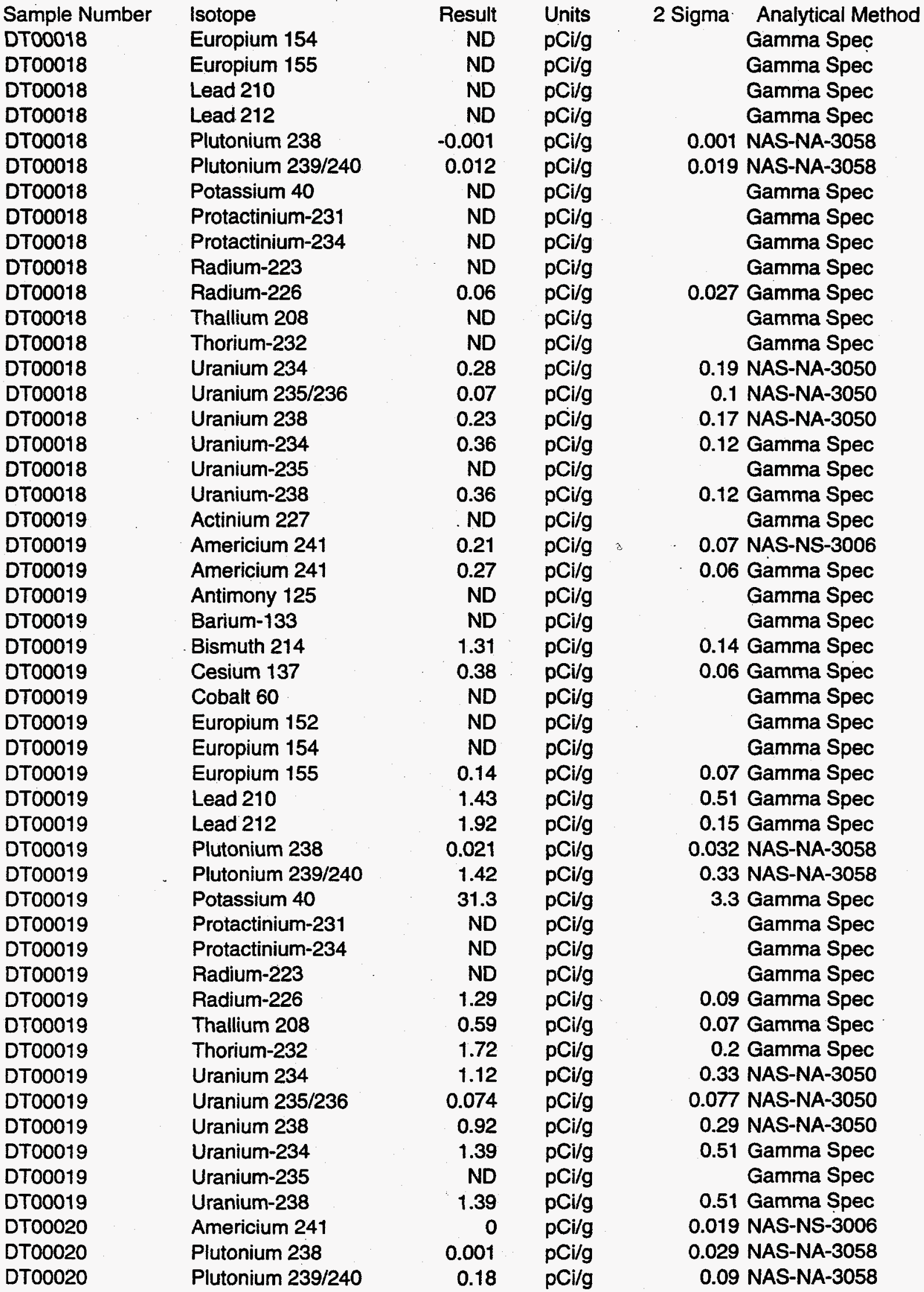


Appendix C

Isotopic Laboratory Analytical Results in Soil

First Characterization Event

\begin{tabular}{|c|c|c|c|c|c|}
\hline Sample Number & Isotope & Result & Units & 2 Sigma & Analytical Method \\
\hline DT00020 & Uranium 234 & 1.05 & $\mathrm{pCi} / \mathrm{g}$ & 0.3 & NAS-NA-3050 \\
\hline DTO0020 & Uranium 235/236 & 0.015 & $\mathrm{pCi} / \mathrm{g}$ & 0.034 & NAS-NA-3050 \\
\hline DT00020 & Uranium 238 & 0.76 & $\mathrm{pCi} / \mathrm{g}$ & 0.25 & NAS-NA-3050 \\
\hline DT00021 & Americium 241 & 0.11 & $\mathrm{pCi} / \mathrm{g}$ & 0.06 & NAS-NS-3006 \\
\hline DT00021 & Plutonium 238 & 0 & $\mathrm{pCi} / \mathrm{g}$ & & NAS-NA-3058 \\
\hline DT00021 & Plutonium 239/240 & 0.2 & $\mathrm{pCi} / \mathrm{g}$ & 0.1 & NAS-NA-3058 \\
\hline DT00021 & Uranium 234 & 1.09 & $\mathrm{pCi} / \mathrm{g}$ & 0.32 & NAS-NA-3050 \\
\hline DT00021 & Uranium 235/236 & 0.053 & $\mathrm{pCi} / \mathrm{g}$ & 0.064 & NAS-NA-3050 \\
\hline DT00021 & Uranium 238 & 0.56 & $\mathrm{pCi} / \mathrm{g}$ & 0.21 & NAS-NA-3050 \\
\hline DT00022 & Americium 241 & 0.29 & $\mathrm{pCi} / \mathrm{g}$ & 0.08 & NAS-NS-3006 \\
\hline DT00022 & Plutonium 238 & -0.008 & $\mathrm{pCi} / \mathrm{g}$ & 0.006 & NAS-NA-3058 \\
\hline DT00022 & Plutonium 239/240 & 0.017 & $\mathrm{pCi} / \mathrm{g}$ & 0.026 & NAS-NA-3058 \\
\hline DT00022 & Uranium 234 & 1.55 & $\mathrm{pCi} / \mathrm{g}$ & 0.4 & NAS-NA-3050 \\
\hline DT00022 & Uranium 235/236 & 0.068 & $\mathrm{pCi} / \mathrm{g}$ & 0.069 & NAS-NA-3050 \\
\hline DT00022 & Uranium 238 & 1.3 & $\mathrm{pCi} / \mathrm{g}$ & 0.35 & NAS-NA-3050 \\
\hline DT00024 & Actinium 227 & 1.35 & $\mathrm{pCi} / \mathrm{g}$ & 0.29 & Gamma Spec \\
\hline DT00024 & Americium 241 & 8.96 & $\mathrm{pCi} / \mathrm{g}$ & 1.56 & NAS-NS-3006 \\
\hline DT00024 & Americium 241 & 12.2 & $\mathrm{pCi} / \mathrm{g}$ & & Gamma Spec \\
\hline DT00024 & Antimony 125 & ND & $\mathrm{pCi} / \mathrm{g}$ & & Gamma Spec \\
\hline DT00024 & Barium-133 & ND & $\mathrm{pCi} / \mathrm{g}$ & & Gamma Spec \\
\hline DT00024 & Bismuth 214 & 1.26 & $\mathrm{pCi} / \mathrm{g}$ & 0.13 & Gamma Spec \\
\hline DT00024 & Cesium 137 & 0.26 & $\mathrm{pCi} / \mathrm{g}$ & 0.05 & Gamma Spec \\
\hline DT00024 & Cobalt 60 & ND & $\mathrm{pCi} / \mathrm{g}$ & & Gamma Spec \\
\hline DT00024 & Europium 152 & ND & $\mathrm{pCi} / \mathrm{g}$ & & Gamma Spec \\
\hline DT00024 & Europium 154 & ND & $\mathrm{pCi} / \mathrm{g}$ & & Gamma Spec \\
\hline DT00024 & Europium 155 & ND & $\mathrm{pCi} / \mathrm{g}$ & & Gamma Spec \\
\hline DTO0024 & Lead 210 & ND & $\mathrm{pCi} / \mathrm{g}$ & & Gamma Spec \\
\hline DT00024 & Lead 212 & 1.86 & $\mathrm{pCi} / \mathrm{g}$ & 0.19 & Gamma Spec \\
\hline DT00024 & Plutonium 238 & 0.47 & $\mathrm{pCi} / \mathrm{g}$ & 0.61 & NAS-NA-3058 \\
\hline DT00024 & Plutonium 239/240 & 80 & $\mathrm{pCi} / \mathrm{g}$ & 15.3 & NAS-NA-3058 \\
\hline DT00024 & Potassium 40 & 32.5 & $\mathrm{pCi} / \mathrm{g}$ & 3.5 & Gamma Spec \\
\hline DT00024 & Protactinium-231 & ND & $\mathrm{pCi} / \mathrm{g}$ & & Gamma Spec \\
\hline DT00024 & Protactinium-234 & 0.2 & $\mathrm{pCi} / \mathrm{g}$ & 0.11 & Gamma Spec \\
\hline DT00024 & Radium-223 & ND & $\mathrm{pCi} / \mathrm{g}$ & & Gamma Spec \\
\hline DT00024 & Radium-226 & 1.28 & $\mathrm{pCi} / \mathrm{g}$ & 0.09 & Gamma Spec \\
\hline DT00024 & Thallium 208 & 0.59 & $\mathrm{pCi} / \mathrm{g}$ & 0.07 & Gamma Spec \\
\hline DT00024 & Thorium-232 & 1.69 & $\mathrm{pCi} / \mathrm{g}$ & 0.2 & Gamma Spec \\
\hline DT00024 & Total Uranium & 1.98 & $u g / g$ & 0.21 & ASTM 5174-91 \\
\hline DT00024 & Uranium 234 & 0.9 & $\mathrm{pCi} / \mathrm{g}$ & 0.28 & NAS-NA-3050 \\
\hline DT00024 & Uranium 235/236 & 0.1 & $\mathrm{pCi} / \mathrm{g}$ & 0.09 & NAS-NA-3050 \\
\hline DT00024 & Uranium 238 & 0.84 & $\mathrm{pCi} / \mathrm{g}$ & 0.26 & NAS-NA-3050 \\
\hline DT00024 & Uranium-234 & 1.86 & pCilg & 0.77 & Gamma Spec \\
\hline DT00024 & Uranium-235 & ND & $\mathrm{pCi} / \mathrm{g}$ & & Gamma Spec \\
\hline DT00024 & Uranium-238 & 1.86 & $\mathrm{pCi} / \mathrm{g}$ & 0.77 & Gamma Spec \\
\hline DT00025 & Americium 241 & 0.089 & $\mathrm{pCi} / \mathrm{g}$ & 0.053 & NAS-NS-3006 \\
\hline DT00025 & Plutonium 238 & 0.025 & $\mathrm{pCi} / \mathrm{g}$ & 0.032 & NAS-NA-3058 \\
\hline DTO0025 & Plutonium 239/240 & 2.41 & $\mathrm{pCi} / \mathrm{g}$ & 0.5 & NAS-NA-3058 \\
\hline DT00025 & Uranium 234 & 1.08 & $\mathrm{pCi} / \mathrm{g}$ & 0.31 & NAS-NA-3050 \\
\hline DT00025 & Uranium 235/236 & 0.051 & $\mathrm{pCi} / \mathrm{g}$ & 0.06 & NAS-NA-3050 \\
\hline DT00025 & Uranium 238 & 1.21 & $\mathrm{pCi} / \mathrm{g}$ & 0.34 & NAS-NA-3050 \\
\hline
\end{tabular}


Appendix C

Isotopic Laboratory Analytical Results in Soil

Sample Number

DTO0026

DT00026

DT00026

DT00026

DT00026

DT00026

DT00028

DT00028

DT00028

DT00028

DT00028

DT00028

DT00028

DT00028

DT00028

DTO0028

DT00028

DT00028

DT00028

DT00028

DT00028

DT00028

DT00028

DT00028

DT00028

DT00028

DT00028

DT00028

DT00028

DT00028

DT00028

DT00028

DT00028

DT00028

DT00029

DT00029

DT00029

DT00029

DT00029

DT00029

DT00030

DT00030

DT00030

DT00030

DT00030

DT00030

DT00032

DT00032

DT00032

DT00032
Isotope

Americium 241

Plutonium 238

Plutonium 239/240

Uranium 234

Uranium 235/236

Uranium 238

Actinium 227

Americium 241

Americium 241

Antimony 125

Barium-133

Bismuth 214

Cesium 137

Cobalt 60

Europium 152

Europium 154

Europium 155

Lead 210

Lead 212

Plutonium 238

Plutonium 239/240

Potassium 40

Protactinium-231

Protactinium-234

Radium-223

Radium-226

Thallium 208

Thorium-232

Uranium 234

Uranium 235/236

Uranium 238

Uranium-234

Uranium-235

Uranium-238

Americium 241

Plutonium 238

Plutonium 239/240

Uranium 234

Uranium 235/236

Uranium 238

Americium 241

Plutonium 238

Plutonium 239/240

Uranium 234

Uranium 235/236

Uranium 238

Actinium 227

Americium 241

Americium 241

Antimony 125

First Characterization Event

Result Units

$0.009 \quad \mathrm{pCi} / \mathrm{g}$

$-0.004 \quad \mathrm{pCi} / \mathrm{g}$

$1.31 \mathrm{pCi} / \mathrm{g}$

$0.42 \mathrm{pCi} / \mathrm{g}$

$0.12 \mathrm{pCi} / \mathrm{g}$

$0.3 \quad \mathrm{pCi} / \mathrm{g}$

$2.34 \mathrm{pCi} / \mathrm{g}$

$0.007 \quad \mathrm{pCi} / \mathrm{g}$

ND $\quad \mathrm{pCi} / \mathrm{g}$

ND , pCi/g

ND $\quad \mathrm{pCi} / \mathrm{g}$

$1.34 \quad \mathrm{pCi} / \mathrm{g}$

$0.31 \mathrm{pCi} / \mathrm{g}$

ND $\quad \mathrm{pCi} / \mathrm{g}$

ND $\quad \mathrm{pCi} / \mathrm{g}$

ND $\quad \mathrm{pCi} / \mathrm{g}$

ND $\quad \mathrm{pCi} / \mathrm{g}$

ND $\quad \mathrm{pCi} / \mathrm{g}$

$1.9 \mathrm{pCi} / \mathrm{g}$

$0.004 \quad \mathrm{pCi} / \mathrm{g}$

$0.077 \mathrm{pCi} / \mathrm{g}$

$31.9 \mathrm{pCi} / \mathrm{g}$

ND $\quad \mathrm{pCi} / \mathrm{g}$

ND $\quad \mathrm{pCi} / \mathrm{g}$

ND $\quad \mathrm{pCi} / \mathrm{g}$

$1.38 \quad \mathrm{pCi} / \mathrm{g}$

$0.64 \quad \mathrm{pCi} / \mathrm{g}$

$1.73 \mathrm{pCi} / \mathrm{g}$

$0.72 \mathrm{pCi} / \mathrm{g}$

$0 \mathrm{pCi} / \mathrm{g}$

$0.68 \quad \mathrm{pCi} / \mathrm{g}$

ND $\quad \mathrm{pCi} / \mathrm{g}$

ND $\quad \mathrm{pCi} / \mathrm{g}$

ND $\quad \mathrm{pCi} / \mathrm{g}$

$0.03 \quad \mathrm{pCi} / \mathrm{g}$

$-0.007 \quad \mathrm{pCi} / \mathrm{g}$

$0.035 \quad \mathrm{pCi} / \mathrm{g}$

$1.01 \mathrm{pCi} / \mathrm{g}$

$0.16 \mathrm{pCi} / \mathrm{g}$

$1 \mathrm{pCi} / \mathrm{g}$

$-0.011 \quad \mathrm{pCi} / \mathrm{g}$

$-0.003 \quad \mathrm{pCi} / \mathrm{g}$

$-0.002 \quad \mathrm{pCi} / \mathrm{g}$

$1.07 \mathrm{pCi} / \mathrm{g}$

$0.082 \mathrm{pCi} / \mathrm{g}$

$1.07 \quad \mathrm{pCi} / \mathrm{g}$

$4.46 \mathrm{pCi} / \mathrm{g}$

$0.076 \quad \mathrm{pCi} / \mathrm{g}$

$3.17 \quad \mathrm{pCi} / \mathrm{g}$

ND $\mathrm{pCi} / \mathrm{g}$
2 Sigma Analytical Method

0.013 NAS-NS-3006

0.004 NAS-NA-3058

0.31 NAS-NA-3058

0.15 NAS-NA-3050

0.08 NAS-NA-3050

0.12 NAS-NA-3050

0.45 Gamma Spec

0.017 NAS-NS-3006

Gamma Spec

Gamma Spec

Gamma Spec

0.17 Gamma Spec

0.07 Gamma Spec

Gamma Spec

Gamma Spec

Gamma Spec

Gamma Spec

Gamma Spec

0.21 Gamma Spec

0.018 NAS-NA-3058

0.053 NAS-NA-3058

3.6 Gamma Spec

Gamma Spec

Gamma Spec

Gamma Spec

0.11 Gamma Spec

0.09 Gamma Spec

0.23 Gamma Spec

0.24 NAS-NA-3050

0 NAS-NA-3050

0.23 NAS-NA-3050

Gamma Spec

Gamma Spec

Gamma Spec

0.03 NAS-NS-3006

0.005 NAS-NA-3058

0.038 NAS-NA-3058

0.31 NAS-NA-3050

0.11 NAS-NA-3050

0.31 NAS-NA-3050

0.007 NAS-NS-3006

0.003 NAS-NA-3058

0.003 NAS-NA-3058

0.3 NAS-NA-3050

0.075 NAS-NA-3050

0.31 NAS-NA-3050

0.68 Gamma Spec

0.059 NAS-NS-3006

0.49 Gamma Spec

Gamma Spec 
Appendix C

Isotopic Laboratory Analytical Results in Soil

First Characterization Event

\begin{tabular}{|c|c|c|c|c|c|}
\hline $\begin{array}{l}\text { Sample Number } \\
\text { DT00032 }\end{array}$ & $\begin{array}{l}\text { Isotope } \\
\text { Barium-133 }\end{array}$ & $\begin{array}{l}\text { Result } \\
\text { ND }\end{array}$ & $\begin{array}{l}\text { Units } \\
\text { pCi/g }\end{array}$ & 2 Sigma & $\begin{array}{l}\text { Analytical Method } \\
\text { Gamma Spec }\end{array}$ \\
\hline DT00032 & Bismuth 214 & 1.09 & $\mathrm{pCi} / \mathrm{g}$ & 0.16 & Gamma Spec \\
\hline DT00032 & Cesium 137 & 0.29 & $\mathrm{pCi} / \mathrm{g}$ & 0.05 & Gamma Spec \\
\hline DT00032 & Cobalt 60 & ND & $\mathrm{pCi} / \mathrm{g}$ & & Gamma Spec \\
\hline DT00032 & Europium 152 & ND & $\mathrm{pCi} / \mathrm{g}$ & & Gamma Spec \\
\hline DT00032 & Europium 154 & ND & $\mathrm{pCi} / \mathrm{g}$ & & Gamma Spec \\
\hline DT00032 & Europium 155 & ND & $\mathrm{pCi} / \mathrm{g}$ & & Gamma Spec \\
\hline DT00032 & Lead 210 & ND & $\mathrm{pCi} / \mathrm{g}$ & & Gamma Spec \\
\hline DT00032 & Lead 212 & 1.88 & $\mathrm{pCi} / \mathrm{g}$ & 0.19 & Gamma Spec \\
\hline DT00032 & Plutonium 238 & -0.012 & $\mathrm{pCi} / \mathrm{g}$ & 0.007 & NAS-NA-3058 \\
\hline DT00032 & Plutonium 239/240 & 0.66 & $\mathrm{pCi} / \mathrm{g}$ & 0.19 & NAS-NA-3058 \\
\hline DT00032 & Potassium 40 & 30.8 & $\mathrm{pCi} / \mathrm{g}$ & 3.5 & Gamma Spec \\
\hline DT00032 & Protactinium-231 & ND & $\mathrm{pCi} / \mathrm{g}$ & & Gamma Spec \\
\hline DT00032 & Protactinium-234 & ND & $\mathrm{pCi} / \mathrm{g}$ & & Gamma Spec \\
\hline DT00032 & Radium-223 & ND & $\mathrm{pCi} / \mathrm{g}$ & & Gamma Spec \\
\hline DT00032 & Radium-226 & 1.12 & $\mathrm{pCi} / \mathrm{g}$ & 0.1 & Gamma Spec \\
\hline DT00032 & Thallium 208 & 0.61 & $\mathrm{pCi} / \mathrm{g}$ & 0.07 & Gamma Spec \\
\hline DT00032 & Thorium-232 & 1.72 & $\mathrm{pCi} / \mathrm{g}$ & 0.28 & Gamma Spec \\
\hline DT00032 & Uranium 234 & 1.13 & $\mathrm{pCi} / \mathrm{g}$ & 0.31 & NAS-NA-3050 \\
\hline DT00032 & Uranium 235/236 & 0.077 & $\mathrm{pCi} / \mathrm{g}$ & 0.07 & NAS-NA-3050 \\
\hline DT00032 & Uranium 238 & 1.07 & $\mathrm{pCi} / \mathrm{g}$ & 0.3 & NAS-NA-3050 \\
\hline DT00032 & Uranium-234 & 1.81 & $\mathrm{pCi} / \mathrm{g}$ & 0.59 & Gamma Spec \\
\hline DT00032 & Uranium-235 & ND & $\mathrm{pCi} / \mathrm{g}$ & & Gamma Spec \\
\hline DT00032 & Uranium-238 & 1.81 & $\mathrm{pCi} / \mathrm{g}$ & 0.59 & Gamma Spec \\
\hline DT00033 & Americium 241 & 0.012 & $\mathrm{pCi} / \mathrm{g}$ & 0.017 & NAS-NS-3006 \\
\hline DT00033 & Plutonium 238 & -0.003 & $\mathrm{pCi} / \mathrm{g}$ & 0.003 & NAS-NA-3058 \\
\hline DT00033 & Plutonium 239/240 & 0.31 & $\mathrm{pCi} / \mathrm{g}$ & 0.12 & NAS-NA-3058 \\
\hline DT00033 & Uranium 234 & 1.03 & $\mathrm{pCi} / \mathrm{g}$ & 0.29 & NAS-NA-3050 \\
\hline DT00033 & Uranium 235/236 & 0.063 & $\mathrm{pCi} / \mathrm{g}$ & 0.064 & NAS-NA-3050 \\
\hline DT00033 & Uranium 238 & 0.94 & $\mathrm{pCi} / \mathrm{g}$ & 0.27 & NAS-NA-3050 \\
\hline DT00034 & Americium 241 & 0.048 & $\mathrm{pCi} / \mathrm{g}$ & 0.034 & NAS-NS-3006 \\
\hline DT00034 & Plutonium 238 & 0.004 & $\mathrm{pCi} / \mathrm{g}$ & 0.018 & NAS-NA-3058 \\
\hline DT00034 & Plutonium 239/240 & 0.039 & $\mathrm{pCi} / \mathrm{g}$ & 0.04 & NAS-NA-3058 \\
\hline DT00034 & Uranium 234 & 0.9 & $\mathrm{pCi} / \mathrm{g}$ & 0.27 & NAS-NA-3050 \\
\hline DT00034 & Uranium 235/236 & 0.046 & $\mathrm{pCi} / \mathrm{g}$ & 0.06 & NAS-NA-3050 \\
\hline DT00034 & Uranium 238 & 1.01 & $\mathrm{pCi} / \mathrm{g}$ & 0.3 & NAS-NA-3050 \\
\hline DT00036 & Actinium 227 & 1.52 & $\mathrm{pCi} / \mathrm{g}$ & 0.31 & Gamma Spec \\
\hline DT00036 & Americium 241 & 2.27 & $\mathrm{pCi} / \mathrm{g}$ & 0.45 & NAS-NS-3006 \\
\hline DT00036 & Americium 241 & 4.16 & $\mathrm{pCi} / \mathrm{g}$ & 1.05 & Gamma Spec \\
\hline DT00036 & Antimony 125 & ND & $\mathrm{pCi} / \mathrm{g}$ & & Gamma Spec \\
\hline DT00036 & Barium-133 & ND & $\mathrm{pCi} / \mathrm{g}$ & & Gamma Spec \\
\hline DT00036 & Bismuth 214 & 1.29 & $\mathrm{pCi} / \mathrm{g}$ & 0.13 & Gamma Spec \\
\hline DT00036 & Cesium 137 & 0.41 & $\mathrm{pCi} / \mathrm{g}$ & 0.06 & Gamma Spec \\
\hline DT00036 & Cobalt 60 & ND & $\mathrm{pCi} / \mathrm{g}$ & & Gamma Spec \\
\hline DT00036 & Europium 152 & ND & $\mathrm{pCi} / \mathrm{g}$ & & Gamma Spec \\
\hline DT00036 & Europium 154 & ND & $\mathrm{pCi} / \mathrm{g}$ & & Gamma Spec \\
\hline DT00036 & Europium 155 & ND & $\mathrm{pCi} / \mathrm{g}$ & & Gamma Spec \\
\hline DT00036 & Lead 210 & ND & $\mathrm{pCi} / \mathrm{g}$ & & Gamma Spec \\
\hline DT00036 & Lead 212 & 1.88 & $\mathrm{pCi} / \mathrm{g}$ & 0.19 & Gamma Spec \\
\hline DT00036 & Plutonium 238 & 0.18 & $\mathrm{pCi} / \mathrm{g}$ & 0.06 & NAS-NA-3058 \\
\hline
\end{tabular}


Appendix C

Isotopic Laboratory Analytical Results in Soil

Sample Number

DT00036

DT00036

DT00036

DT00036

DT00036

DT00036

DT00036

DT00036

DT00036

DT00036

DT00036

DT00036

DTO0036

DT00036

DT00037

DT00037

DT00037

DT00037

DT00037

DT00037

DT00038

DT00038

DT00038

DT00038

DT00038

DT00038

DT00040

DT00040

DT00040

DT00040

DT00040

DT00040

DT00040

DT00040

DT00040

DT00040

DTO0040

DT00040

DT00040

DT00040

DT00040

DT00040

DT00040

DT00040

DT00040

DTO0040

DTO0040

DT00040

DT00040

DT00040
Isotope

Plutonium 239/240

Potassium 40

Protactinium-231

Protactinium-234

Radium-223

Radium-226

Thallium 208

Thorium-232

Uranium 234

Uranium 235/236

Uranium 238

Uranium-234

Uranium-235

Uranium-238

Americium 241

Plutonium 238

Plutonium 239/240

Uranium 234

Uranium 235/236

Uranium 238

Americium 241

Plutonium 238

Plutonium 239/240

Uranium 234

Uranium 235/236

Uranium 238

Actinium 227

Americium 241

Americium 241

Americium 241

Antimony 125

Barium-133

Bismuth 214

Cesium 137

Cobalt 60

Europium 152

Europium 154

Europium 155

Lead 210

Lead 212

Plutonium 238

Plutonium 239/240

Potassium 40

Protactinium-231

Protactinium-234

Radium-223

Radium-226

Thallium 208

Thorium-232

Total Uranium
First Characterization Event

$\begin{array}{rrr}\text { Result } & \text { Units } & \text { 2 Sigma } \\ 29.3 & \mathrm{pCi} / \mathrm{g} & 4.6 \text { NAS-NA-3058 } \\ 32.6 & \mathrm{pCi} / \mathrm{g} & 3.5 \text { Gamma Spec } \\ \mathrm{ND} & \mathrm{pCi} / \mathrm{g} & \text { Gamma Spec } \\ \mathrm{ND} & \mathrm{pCi} / \mathrm{g} & \text { Gamma Spec } \\ \mathrm{ND} & \mathrm{pCi} / \mathrm{g} & \text { Gamma Spec } \\ 1.36 & \mathrm{pCi} / \mathrm{g} & 0.09 \text { Gamma Spec } \\ 0.62 & \mathrm{pCi} / \mathrm{g} & 0.07 \text { Gamma Spec } \\ 1.74 & \mathrm{pCi} / \mathrm{g} & 0.21 \text { Gamma Spec } \\ 0.81 & \mathrm{pCi} / \mathrm{g} & 0.19 \text { NAS-NA-3050 } \\ 0.046 & \mathrm{pCi} / \mathrm{g} & 0.039 \text { NAS-NA-3050 } \\ 0.82 & \mathrm{pCi} / \mathrm{g} & 0.19 \text { NAS-NA-3050 } \\ \mathrm{ND} & \mathrm{pCi} / \mathrm{g} & \text { Gamma Spec } \\ \mathrm{ND} & \mathrm{pCi} / \mathrm{g} & \text { Gamma Spec } \\ \mathrm{ND} & \mathrm{pCi} / \mathrm{g} & \text { Gamma Spec }\end{array}$

0.015 NAS-NS-3006

0.011 NAS-NA-3058

0.21 NAS-NA-3058

0.21 NAS-NA-3050

0.039 NAS-NA-3050

0.19 NAS-NA-3050

0.011 NAS-NS-3006

0.013 NAS-NA-3058

0.02 NAS-NA-3058

0.3 NAS-NA-3050

Q.042 NAS-NA-3050

0.28 NAS-NA-3050

0.67 Gamma Spec

3.1 NAS-NS-3006

3.8 Gamma Spec

9.4 Gamma Spec

Gamma Spec

Gamma Spec

0.17 Gamma Spec

0.06 Gamma Spec

Gamma Spec

Gamma Spec

Gamma Spec

Gamma Spec

6.1 Gamma Spec

0.2 Gamma Spec

1.38 NAS-NA-3058

58 NAS-NA-3058

3.7 Gamma Spec

Gamma Spec

0.13 Gamma Spec

Gamma Spec

0.11 Gamma Spec

0.08 Gamma Spec

0.31 Gamma Spec

0.27 ASTM 5174-91 
Appendix C

Isotopic Laboratory Analytical Results in Soil

First Characterization Event

\begin{tabular}{|c|c|c|c|c|c|}
\hline Sample Number & Isotope & Result & Units & 2 Sigma & Analytical Method \\
\hline DT00040 & Uranium 234 & 1.11 & $\mathrm{pCi} / \mathrm{g}$ & 0.25 & NAS-NA-3050 \\
\hline DT00040 & Uranium 235/236 & 0.08 & $\mathrm{pCi} / \mathrm{g}$ & 0.05 & NAS-NA-3050 \\
\hline DT00040 & Uranium 238 & 0.86 & $\mathrm{pCi} / \mathrm{g}$ & 0.2 & NAS-NA-3050 \\
\hline DT00040 & Uranium-234 & 1.9 & $\mathrm{pCi} / \mathrm{g}$ & 0.62 & Gamma Spec \\
\hline DT00040 & Uranium-235 & ND & $\mathrm{pCi} / \mathrm{g}$ & & Gamma Spec \\
\hline DT00040 & Uranium-238 & 1.9 & $\mathrm{pCi} / \mathrm{g}$ & 0.62 & - Gamma Spec \\
\hline DTO0040 RE & Americium 241 & 8.63 & $\mathrm{pCi} / \mathrm{g}$ & 3.37 & NAS-NS-3006 \\
\hline DT00040 RE & Plutonium 238 & 2.44 & $\mathrm{pCi} / \mathrm{g}$ & 1.46 & NAS-NS-3058 \\
\hline DT00040 RE & Plutonium 239/240 & 292 & $\mathrm{pCi} / \mathrm{g}$ & 51 & NAS-NS-3058 \\
\hline DT00041 & Americium 241 & 0.18 & $\mathrm{pCi} / \mathrm{g}$ & 0.05 & NAS-NS-3006 \\
\hline DT00041 & Plutonium 238 & 0.26 & $\mathrm{pCi} / \mathrm{g}$ & 0.47 & NAS-NA-3058 \\
\hline DT00041 & Plutonium 239/240 & 0.82 & $\mathrm{pCi} / \mathrm{g}$ & 0.75 & 5 NAS-NA-3058 \\
\hline DT00041 & Uranium 234 & 0.78 & $\mathrm{pCi} / \mathrm{g}$ & 0.19 & NAS-NA-3050 \\
\hline DT00041 & Uranium 235/236 & 0.046 & $\mathrm{pCi} / \mathrm{g}$ & 0.036 & NAS-NA-3050 \\
\hline DT00041 & Uranium 238 & 0.66 & $\mathrm{pCi} / \mathrm{g}$ & 0.17 & 7 NAS-NA-3050 \\
\hline DT00042 & Americium 241 & 0.14 & $\mathrm{pCi} / \mathrm{g}$ & 0.04 & 4 NAS-NS-3006 \\
\hline DT00042 & Plutonium 238 & 0.003 & $\mathrm{pCi} / \mathrm{g}$ & 0.013 & 3 NAS-NA-3058 \\
\hline DT00042 & Plutonium 239/240 & 0.27 & $\mathrm{pCi} / \mathrm{g}$ & 0.08 & 3 NAS-NA-3058 \\
\hline DT00042 & Uranium 234 & 0.79 & $\mathrm{pCi} / \mathrm{g}$ & 0.2 & 2 NAS-NA-3050 \\
\hline DT00042 & Uranium 235/236 & 0.043 & $\mathrm{pCi} / \mathrm{g}$ & 0.039 & 9 NAS-NA-3050 \\
\hline DT00042 & Uranium 238 & 0.92 & $\mathrm{pCi} / \mathrm{g}$ & 0.22 & 2 NAS-NA-3050 \\
\hline DT00043 & Americium 241 & 1.42 & $\mathrm{pCi} / \mathrm{g}$ & 0.42 & NAS-NS-3006 \\
\hline DT00043 & Plutonium 238 & 0.21 & $\mathrm{pCi} / \mathrm{g}$ & 0.04 & 4 NAS-NA-3058 \\
\hline DT00043 & Plutonium 239/240 & 30.8 & $\mathrm{pCi} / \mathrm{g}$ & 4.8 & 3 NAS-NA-3058 \\
\hline DT00043 & Uranium 234 & 1.24 & $\mathrm{pCi} / \mathrm{g}$ & 0.27 & 7 NAS-NA-3050 \\
\hline DT00043 & Uranium $235 / 236^{\circ}$ & 0.032 & $\mathrm{pCi} / \mathrm{g}$ & 0.034 & 4 NAS-NA-3050 \\
\hline DT00043 & Uranium 238 & 1.06 & $\mathrm{pCi} / \mathrm{g}$ & 0.24 & 4 NAS-NA-3050 \\
\hline DTO0045 & Actinium 227 & ND & $\mathrm{pCi} / \mathrm{g}$ & & Gamma Spec \\
\hline DT00045 & Americium 241 & 0.081 & $\mathrm{pCi} / \mathrm{g}$ & 0.052 & NAS-NS-3006 \\
\hline DT00045 & Americium 241 & 1.3 & $\mathrm{pCi} / \mathrm{g}$ & 0.16 & Gamma Spec \\
\hline DT00045 & Antimony 125 & ND & $\mathrm{pCi} / \mathrm{g}$ & & Gamma Spec \\
\hline DT00045 & Barium-133 & ND & $\mathrm{pCi} / \mathrm{g}$ & & Gamma Spec \\
\hline DTO0045 & Bismuth 214 & 1.24 & $\mathrm{pCi} / \mathrm{g}$ & 0.16 & Gamma Spec \\
\hline DT00045 & Cesium 137 & 0.29 & $\mathrm{pCi} / \mathrm{g}$ & 0.05 & 5 Gamma Spec \\
\hline DT00045 & Cobalt 60 & ND & $\mathrm{pCi} / \mathrm{g}$ & & Gamma Spec \\
\hline DTO0045 & Europium 152 & ND & $\mathrm{pCi} / \mathrm{g}$ & & Gamma Spec \\
\hline DT00045 & Europium 154 & ND & $\mathrm{pCi} / \mathrm{g}$ & & Gamma Spec \\
\hline DT00045 & Europium 155 & ND & $\mathrm{pCi} / \mathrm{g}$ & & Gamma Spec \\
\hline DT00045 & Lead 210 & 1.66 & $\mathrm{pCi} / \mathrm{g}$ & 0.55 & 5 Gamma Spec \\
\hline DT00045 & Lead 212 & 1.69 & $\mathrm{pCi} / \mathrm{g}$ & 0.17 & 7 Gamma Spec \\
\hline DT00045 & Plutonium 238 & 0.007 & $\mathrm{pCi} / \mathrm{g}$ & 0.016 & 6 NAS-NA-3058 \\
\hline DT00045 & Plutonium 239/240 & 2.33 & $\mathrm{pCi} / \mathrm{g}$ & 0.47 & 7 NAS-NA-3058 \\
\hline DT00045 & Potassium 40 & 32 & $\mathrm{pCi} / \mathrm{g}$ & 3.3 & 3 Gamma Spec \\
\hline DT00045 & Protactinium-231 & ND & $\mathrm{pCi} / \mathrm{g}$ & & Gamma Spec \\
\hline DT00045 & Protactinium-234 & ND & $\mathrm{pCi} / \mathrm{g}$ & & Gamma Spec \\
\hline DT00045 & Radium-223 & ND & $\mathrm{pCi} / \mathrm{g}$ & & Gamma Spec \\
\hline DT00045 & Radium-226 & 1.28 & $\mathrm{pCi} / \mathrm{g}$ & 0.09 & 9 Gamma Spec \\
\hline DT00045 & Thallium 208 & 0.67 & $\mathrm{pCi} / \mathrm{g}$ & 0.08 & 3 Gamma Spec \\
\hline DTO0045 & Thorium-232 & 1.84 & $\mathrm{pCi} / \mathrm{g}$ & 0.2 & 2 Gamma Spec \\
\hline DTO0045 & Uranium 234 & 1.15 & $\mathrm{pCi} / \mathrm{g}$ & 0.39 & 9 NAS-NA-3050 \\
\hline
\end{tabular}


Appendix C

Isotopic Laboratory Analytical Results in Soil

Sample Number

DT00045

DT00045

DT00045

DT00045

DT00045

DT00046

DT00046

DT00046

DT00046

DT00046

DT00046

DT00047

DT00047

DT00047.

DT00047

DT00047

DT00047

DT00049

DT00049

DT00049

DT00049

DT00049

DT00049

DT00049

DT00049

DT00049

DT00049

DT00049

DT00049

DT00049

DT00049

DT00049

DT00049

DT00049

DT00049

DT00049

DT00049

DT00049

DT00049

DT00049

DTO0049

DT00049

DT00049

DT00049

DT00049

DT00049 RE

DTO0049 RE

DT00049 RE

DT00050

DT00050
Isotope

Uranium 235/236

Uranium 238

Uranium-234

Uranium-235

Uranium-238

Americium 241

Plutonium 238

Plutonium 239/240

Uranium 234

Uranium 235/236

Uranium 238

Americium 241

Plutonium 238

Plutonium 239/240

Uranium 234

Uranium 235/236

Uranium 238

Actinium 227

Americium 241

Americium 241

Antimony 125

Barium-133

Bismuth 214

Cesium 137

Cobalt 60

Europium 152

Europium 154

Europium 155

Lead 210

Lead 212

Plutonium 238

Plutonium 239/240

Potassium 40

Protactinium-231

Protactinium-234

Radium-223

Radium-226

Thallium 208

Thorium-232

Uranium 234

Uranium 235/236

Uranium 238

Uranium-234

Uranium-235

Uranium-238

Americium 241

Plutonium 238

Plutonium 239/240

Americium 241

Plutonium 238
First Characterization Event

\begin{tabular}{|c|c|}
\hline Result & Units \\
\hline 0.57 & $\mathrm{pCi} / \mathrm{g}$ \\
\hline 1.11 & $\mathrm{pCi} / \mathrm{g}$ \\
\hline 1.07 & $\mathrm{pCi} / \mathrm{g}$ \\
\hline ND & $\mathrm{pCi} / \mathrm{g}$ \\
\hline 1.07 & pCi/g \\
\hline 0.19 & $\mathrm{pCi} / \mathrm{g}$ \\
\hline 0.006 & $\mathrm{pCi} / \mathrm{g}$ \\
\hline 0.68 & $\mathrm{pCi} / \mathrm{g}$ \\
\hline 3.43 & $\mathrm{pCi} / \mathrm{g}$ \\
\hline 2.18 & $\mathrm{pCi} / \mathrm{g}$ \\
\hline 3.12 & pCi/g \\
\hline 0.17 & $\mathrm{pCi} / \mathrm{g}$ \\
\hline-0.008 & $\mathrm{pCi} / \mathrm{g}$ \\
\hline 0.11 & $\mathrm{pCi} / \mathrm{g}$ \\
\hline 1.29 & $\mathrm{pCi} / \mathrm{g}$ \\
\hline 0.082 & $\mathrm{pCi} / \mathrm{g}$ \\
\hline 1 & $\mathrm{pCl} / \mathrm{g}$ \\
\hline ND & $\mathrm{pCi} / \mathrm{g}$ \\
\hline 0.053 & $\mathrm{pCi} / \mathrm{g}$ \\
\hline 0.64 & $\mathrm{pCi} / \mathrm{g}$ \\
\hline ND & $\mathrm{pCi} / \mathrm{g}$ \\
\hline ND & $\mathrm{pCi} / \mathrm{g}$ \\
\hline 1.38 & $\mathrm{pCi} / \mathrm{g}$ \\
\hline
\end{tabular}

$0.46 \mathrm{pCi} / \mathrm{g}$

ND $\quad \mathrm{pCi} / \mathrm{g}$

ND $\quad \mathrm{pCi} / \mathrm{g}$

ND $\quad \mathrm{pCi} / \mathrm{g}$

ND $\quad \mathrm{pCi} / \mathrm{g}$

$1.39 \quad \mathrm{pCi} / \mathrm{g}$

$1.94 \quad \mathrm{pCi} / \mathrm{g}$

$0.034 \mathrm{pCi} / \mathrm{g}$

$2.23 \mathrm{pCi} / \mathrm{g}$

$33.5 \mathrm{pCi} / \mathrm{g}$

ND $\mathrm{pCi} / \mathrm{g}$

$0.17 \quad \mathrm{pCi} / \mathrm{g}$

ND $\mathrm{pCi} / \mathrm{g}$

$1.34 \mathrm{pCi} / \mathrm{g}$

$0.61 \mathrm{pCi} / \mathrm{g}$

$1.75 \mathrm{pCi} / \mathrm{g}$

$1.11 \mathrm{pCi} / \mathrm{g}$

$0.11 \quad \mathrm{pCi} / \mathrm{g}$

$0.94 \quad \mathrm{pCi} / \mathrm{g}$

$1.24 \quad \mathrm{pCi} / \mathrm{g}$

ND $\quad \mathrm{pCi} / \mathrm{g}$

$1.24 \mathrm{pCi} / \mathrm{g}$

$0.035 \mathrm{pCi} / \mathrm{g}$

$0.009 \quad \mathrm{pCi} / \mathrm{g}$

$0.63 \quad \mathrm{pCi} / \mathrm{g}$

$0.056 \quad \mathrm{pCi} / \mathrm{g}$

$0.007 \quad \mathrm{pCi} / \mathrm{g}$
Sigma Analytical Method

0.28 NAS-NA-3050

0.38 NAS-NA-3050

0.49 Gamma Spec

Gamma Spec

0.49 Gamma Spec

0.07 NAS-NS-3006

0.014 NAS-NA-3058

0.18 NAS-NA-3058

0.79 NAS-NA-3050

0.56 NAS-NA-3050

0.73 NAS-NA-3050

0.07 NAS-NS-3006

0.005 NAS-NA-3058

0.06 NAS-NA-3058

0.35 NAS-NA-3050

0.075 NAS-NA-3050

0.29 NAS-NA-3050

Gamma Spec

0.026 NAS-NS-3006

0.09 Gamma Spec

Gamma Spec

Gamma Spec

0.14 Gamma Spec

0.07 Gamma Spec

Gamma Spec

Gamma Spec

Gamma Spec

Gamma Spec

0.49 Gamma Spec

0.15 Gamma Spec

0.026 NAS-NA-3058

0.39 NAS-NA-3058

3.3 Gamma Spec

Gamma Spec

0.09 Gamma Spec

Gamma Spec

0.09 Gamma Spec

0.07 Gamma Spec

0.19 Gamma Spec

0.24 NAS-NA-3050

0.06 NAS-NA-3050

0.21 NAS-NA-3050

0.53 Gamma Spec

Gamma Spec

0.53 Gamma Spec

0.019 NAS-NS-3006

0.008 NAS-NS-3058

0.12 NAS-NS-3058

0.023 NAS-NS-3006

0.014 NAS-NA-3058 
Appendix C

Isotopic Laboratory Analytical Results in Soil

First Characterization Event

\begin{tabular}{|c|c|c|c|c|c|}
\hline $\begin{array}{l}\text { Sample Number } \\
\text { DT00050 }\end{array}$ & $\begin{array}{l}\text { Isotope } \\
\text { Plutonium 239/240 }\end{array}$ & $\begin{array}{c}\text { Result } \\
0.11\end{array}$ & $\begin{array}{l}\text { Units } \\
\text { pCi/g }\end{array}$ & $\begin{array}{r}2 \text { Sigma } \\
0.05\end{array}$ & $\begin{array}{r}\text { Analytical Me } \\
\text { NAS-NA-3058 }\end{array}$ \\
\hline DT00050 & Uranium 234 & 0.99 & $\mathrm{pCi} / \mathrm{g}$ & 0.23 & 3 NAS-NA-3050 \\
\hline DT00050 & Uranium 235/236 & 0.085 & $\mathrm{pCi} / \mathrm{g}$ & 0.056 & NAS-NA-3050 \\
\hline DT00050 & Uranium 238 & 0.97 & $\mathrm{pCi} / \mathrm{g}$ & 0.23 & 3 NAS-NA-3050 \\
\hline DT00051 & Americium 241 & 0.086 & $\mathrm{pCi} / \mathrm{g}$ & 0.028 & 3 NAS-NS-3006 \\
\hline DT00051 & Plutonium 238 & 0.025 & $\mathrm{pCi} / \mathrm{g}$ & 0.025 & 5 NAS-NA-3058 \\
\hline DT00051 & Plutonium $239 / 240$ & 0.036 & $\mathrm{pCi} / \mathrm{g}$ & 0.028 & 3 NAS-NA-3058 \\
\hline DT00051 & Uranium 234 & 1.15 & $\mathrm{pCi} / \mathrm{g}$ & 0.25 & 5 NAS-NA-3050 \\
\hline DT00051 & Uranium 235/236 & 0.17 & $\mathrm{pCi} / \mathrm{g}$ & 0.08 & 3 NAS-NA-3050 \\
\hline DT00051 & Uranium 238 & 0.93 & $\mathrm{pCi} / \mathrm{g}$ & 0.22 & 2 NAS-NA-3050 \\
\hline DT00001 & Actinium 227 & ND & pCi/l & & Gamma Spec \\
\hline DT00001 & Americium 241 & 0.012 & $\mathrm{pCi} / /$ & 0.062 & NAS-NS-3006 \\
\hline DT00001 & Americium 241 & ND & $\mathrm{pCi} / 1$ & & Gamma Spec \\
\hline DT00001 & Antimony 125 & ND & $\mathrm{pCi} / /$ & & Gamma Spec \\
\hline DT00001 & Barium-133 & ND & $\mathrm{pCi} / /$ & & Gamma Spec \\
\hline DT00001 & Bismuth 214 & 14.4 & $\mathrm{pCi} / 1$ & 8.2 & Gamma Spec \\
\hline DT00001 & Cesium 137 & ND & $\mathrm{pCi} / \mathrm{l}$ & & Gamma Spec \\
\hline DT00001 & Cobalt 60 & ND & $\mathrm{pCi} / \mathrm{l}$ & & Gamma Spec \\
\hline DT00001 & Europium 152 & ND & pCi/l & & Gamma Spec \\
\hline DT00001 & Europium 154 & ND & $\mathrm{pCi} / \mathrm{l}$ & & Gamma Spec \\
\hline DT00001 & Europium 155 & ND & $\mathrm{pCi} / 1$ & & Gamma Spec \\
\hline DT00001 & Lead 210 & 208 & $\mathrm{pCi} / \mathrm{I}$ & 54 & 4 Gamma Spec \\
\hline DT00001 & Lead 212 & 10.5 & $\mathrm{pCi} / 1$ & & Gamma Spec \\
\hline DT00001 & Plutonium 238 & 0.13 & $\mathrm{pCi} / \mathrm{l}$ & 0.1 & NAS-NS-3058 \\
\hline DT00001 & Plutonium 239/240 & 0.15 & pCi/l & 0.09 & NAS-NS-3058 \\
\hline DT00001 & Potassium 40 & ND & $\mathrm{pCi} / \mathrm{l}$ & & Gamma Spec \\
\hline DT00001 & Protactinium-231 & ND & $\mathrm{pCi} / \mathrm{I}$ & & Gamma Spec \\
\hline DT00001 & Protactinium-234 & ND & $\mathrm{pCi} / \mathrm{l}$ & & Gamma Spec \\
\hline DT00001 & Radium-223 & ND & $\mathrm{pCi} / /$ & & Gamma Spec \\
\hline DT00001 & Radium-226 & 14.4 & $\mathrm{pCi} / \mathrm{l}$ & 8.2 & 2 Gamma Spec \\
\hline DT00001 & Thallium 208 & ND & pCi/l & & Gamma Spec \\
\hline DT00001 & Thorium-232 & ND & $\mathrm{pCi} / /$ & & Gamma Spec \\
\hline DTO0001 & Uranium 234 & -0.06 & $\mathrm{pCi} / \mathrm{l}$ & 0.08 & NAS-NA-3050 \\
\hline DT00001 & Uranium 235/236 & 1.03 & $\mathrm{pCi} / 1$ & 2.16 & NAS-NA-3050 \\
\hline DT00001 & Uranium 238 & -0.08 & $\mathrm{pCi} / \mathrm{l}$ & 0.09 & NAS-NA-3050 \\
\hline DT00001. & Uranium-234 & 397 & $\mathrm{pCi} / \mathrm{I}$ & 74 & Gamma Spec \\
\hline DT00001 & Uranium-235 & ND & $\mathrm{pCi} / 1$ & & Gamma Spec \\
\hline DT00001 & Uranium-238 & 397 & $\mathrm{pCi} / 1$ & 74 & Gamma Spec \\
\hline DT00001 RE & Uranium 234 & 0.14 & $\mathrm{pCi} / \mathrm{I}$ & 0.21 & NAS-NA-3050 \\
\hline DT00001 RE & Uranium 235/236 & 0.089 & $\mathrm{pCi} / 1$ & 0.18 & 3 NAS-NA-3050 \\
\hline DT00001 RE & Uranium 238 & 0 & $\mathrm{pCi} / 1$ & & NAS-NA-3050 \\
\hline DTO0053 & Actinium 227 & ND & $\mathrm{pCi} / 1$ & & Gamma Spec \\
\hline DT00053 & Americium 241 & 0.095 & $\mathrm{pCin}$ & 0.1 & NAS-NS-3006 \\
\hline DT00053 & Americium 241 & ND & $\mathrm{pCi} / \mathrm{l}$ & & Gamma Spec \\
\hline DT00053 & Antimony 125 & ND & $\mathrm{pCi} / \mathrm{l}$ & & Gamma Spec \\
\hline DT00053 & Barium-133 & ND & $\mathrm{pCi} / 1$ & & Gamma Spec \\
\hline DT00053 & Bismuth 214 & ND & $\mathrm{pCi} /$ & & Gamma Spec \\
\hline DT00053 & Cesium 137 & ND & $\mathrm{pCi} / 1$ & & Gamma Spec \\
\hline DT00053 & Cobalt 60 & ND & $\mathrm{pCi} / \mathrm{l}$ & & Gamma Spec \\
\hline DT00053 & Europium 152 & ND & $\mathrm{pCi} / /$ & & Gamma Spec \\
\hline
\end{tabular}


Appendix C

Isotopic Laboratory Analytical Results in Soil

First Characterization Event

\begin{tabular}{|c|c|c|c|c|c|}
\hline $\begin{array}{l}\text { Sample Number } \\
\text { DT00053 }\end{array}$ & $\begin{array}{l}\text { Isotope } \\
\text { Europium } 154\end{array}$ & $\begin{array}{c}\text { Result } \\
\text { ND }\end{array}$ & $\begin{array}{l}\text { Units } \\
\text { pCi/l }\end{array}$ & 2 Sigma & $\begin{array}{l}\text { Analytical Meth } \\
\text { Gamma Spec }\end{array}$ \\
\hline DTO0053 & Europium 155 & ND & $\mathrm{pCi} / \mathrm{l}$ & & Gamma Spec \\
\hline DT00053 & Lead 210 & ND & $\mathrm{pCi} / \mathrm{l}$ & & Gamma Spec \\
\hline DT00053 & Lead 212 & ND & $\mathrm{pCi} / \mathrm{l}$ & & Gamma Spec \\
\hline DT00053 & Plutonium 238 & 0.005 & $\mathrm{pCi} / \mathrm{l}$ & 0.014 & NAS-NS-3058 \\
\hline DT00053 & Plutonium 239/240 & -0.002 & $\mathrm{pCi} /$ & 0.011 & NAS-NS-3058 \\
\hline DT00053 & Potassium 40 & ND & $\mathrm{pCi} / 1$ & & Gamma Spec \\
\hline DT00053 & Protactinium-231 & ND & $\mathrm{pCi} / \mathrm{l}$ & & Gamma Spec \\
\hline DT00053 & Protactinium-234 & ND & $\mathrm{pCi} / \mathrm{l}$ & & Gamma Spec \\
\hline DT00053 & Radium-223 & ND & $\mathrm{pCi} / \mathrm{l}$ & & Gamma Spec \\
\hline DT00053 & Radium-226 & ND & $\mathrm{pCi} / \mathrm{l}$ & & Gamma Spec \\
\hline DT00053 & Thallium 208 & ND & $\mathrm{pCi} / \mathrm{l}$ & & Gamma Spec \\
\hline DT00053 & Thorium-232 & ND & $\mathrm{pCi} / /$ & & Gamma Spec \\
\hline DT00053 & Uranium 234 & 0.23 & $\mathrm{pCi} / \mathrm{l}$ & 0.34 & 4 NAS-NA-3050 \\
\hline DT00053 & Uranium 235/236 & 0 & $\mathrm{pCi} / \mathrm{l}$ & 0.01 & NAS-NA-3050 \\
\hline DTO0053 & Uranium 238 & 0.12 & $\mathrm{pCi} / 1$ & 0.24 & 4 NAS-NA-3050 \\
\hline DT00053 & Uranium-234 & 434 & $\mathrm{pCi} / 1$ & & Gamma Spec \\
\hline DT00053 & Uranium-235 & 23.5 & $\mathrm{pCi} / \mathrm{l}$ & 13.2 & 2 Gamma Spec \\
\hline DT00053 & Uranium-238 & 434 & $\mathrm{pCi} / 1$ & & Gamma Spec \\
\hline DT00054 & Actinium 227 & ND & $\mathrm{pCi} / 1$ & & Gamma Spec \\
\hline DT00054 & Americium 241 & -0.035 & $\mathrm{pCi} / 1$ & 0.036 & 3 NAS-NS-3006 \\
\hline DT00054 & Americium 241 & ND & $\mathrm{pCi} / \mathrm{l}$ & & Gamma Spec \\
\hline DT00054 & Antimony 125 & ND & $\mathrm{pCi} / \mathrm{l}$ & & Gamma Spec \\
\hline DT00054 & Barium-133 & ND & $\mathrm{pCi} / \mathrm{l}$ & & Gamma Spec \\
\hline DT00054 & Bismuth 214 & 14.8 & $\mathrm{pCi} / 1$ & 6.8 & 3 Gamma Spec \\
\hline DT00054 & Cesium 137 & ND & $\mathrm{pCi} / /$ & & Gamma Spec \\
\hline DT00054 & Cobalt 60 & ND & $\mathrm{pCi} / \mathrm{l}$ & & Gamma Spec \\
\hline DT00054 & Europium 152 & ND & $\mathrm{pCi} / /$ & & Gamma Spec \\
\hline DT00054 & Europium 154 & ND & $\mathrm{pCi} / \mathrm{I}$ & & Gamma Spec \\
\hline DT00054 & Europium 155 & ND & $\mathrm{pCi} / \mathrm{l}$ & & Gamma Spec \\
\hline DT00054 & Lead 210 & ND & $\mathrm{pCi} / \mathrm{l}$ & & Gamma Spec \\
\hline DTO0054 & Lead 212 & ND & $\mathrm{pCi} / \mathrm{l}$ & & Gamma Spec \\
\hline DT00054 & Plutonium 238 & 0.006 & $\mathrm{pCi} / \mathrm{l}$ & 0.018 & 3 NAS-NS-3058 \\
\hline DT00054 & Plutonium $239 / 240$ & 0.02 & $\mathrm{pCi} / /$ & 0.021 & NAS-NS-3058 \\
\hline DT00054 & Potassium 40 & ND & $\mathrm{pCi} / 1$ & & Gamma Spec \\
\hline DT00054 & Protactinium-231 & ND & $\mathrm{pCi} / 1$ & & Gamma Spec \\
\hline DT00054 & Protactinium-234 & ND & $\mathrm{pCi} / \mathrm{l}$ & & Gamma Spec \\
\hline DTO0054 & Radium-223 & ND & $\mathrm{pCi} / \mathrm{l}$ & & Gamma Spec \\
\hline DT00054 & Radium-226 & 14.8 & $\mathrm{pCi} / \mathrm{l}$ & 6.8 & 3 Gamma Spec \\
\hline DT00054 & Thallium 208 & ND & $\mathrm{pCi} / /$ & & Gamma Spec \\
\hline DTO0054 & Thorium-232 & ND & $\mathrm{pCi} / 1$ & & Gamma Spec \\
\hline DT00054 & Uranium 234 & 0.37 & $\mathrm{pCi} / \mathrm{l}$ & 0.31 & NAS-NA-3050 \\
\hline DT00054 & Uranium 235/236 & 0 & $\mathrm{pCi} / \mathrm{l}$ & & NAS-NA-3050 \\
\hline DT00054 & Uranium 238 & 0.06 & $\mathrm{pCi} / \mathrm{l}$ & 0.12 & NAS-NA-3050 \\
\hline DT00054 & Uranium-234 & 412 & $\mathrm{pCi} / \mathrm{l}$ & 73 & 3 Gamma Spec \\
\hline DT00054 & Uranium-235 & ND & $\mathrm{pCi} / \mathrm{l}$ & & Gamma Spec \\
\hline DT00054 & Uranium-238 & 412 & $\mathrm{DCi} / 1$ & 73 & 3 Gamma Spec \\
\hline QCBLK & Americium 241 & 0.002 & $\mathrm{pCi} / \mathrm{g}$ & 0.006 & 6 NAS-NS-3006 \\
\hline QCBLK & Americium 241 & 0.026 & $\mathrm{pCi} / \mathrm{g}$ & 0.032 & NAS-NS-3006 \\
\hline QCBLK & Americium 241 & 0.03 & $\mathrm{pCi} / \mathrm{g}$ & 0.042 & NAS-NS-3006 \\
\hline
\end{tabular}


Appendix C

Isotopic Laboratory Analytical Results in Soil

First Characterization Event

\begin{tabular}{|c|c|c|c|c|c|}
\hline $\begin{array}{l}\text { Sample Number } \\
\text { QCBLK }\end{array}$ & $\begin{array}{l}\text { Isotope } \\
\text { Americium } 241\end{array}$ & $\begin{array}{c}\text { Result } \\
0.094\end{array}$ & $\begin{array}{l}\text { Units } \\
\mathrm{pCi} / \mathrm{g}\end{array}$ & $\begin{array}{r}2 \text { Sigma } \\
0.137\end{array}$ & $\begin{array}{l}\text { Analytical Method } \\
\text { NAS-NS-3006 }\end{array}$ \\
\hline QCBLK & Americium 241 & 0.001 & $\mathrm{pCi} / \mathrm{g}$ & 0.004 & NAS-NS-3006 \\
\hline QCBLK & Plutonium 238 & 0 & $p C i / g$ & & NAS-NS-3058 \\
\hline QCBLK & Plutonium 238 & -0.005 & $\mathrm{pCi} / \mathrm{g}$ & 0.019 & NAS-NS-3058 \\
\hline QCBLK & Plutonium 238 & 0.001 & $\mathrm{pCi} / \mathrm{g}$ & 0.019 & NAS-NS-3058 \\
\hline QCBLK & Plutonium 238 & 0.009 & $\mathrm{pCi} / \mathrm{g}$ & 0.016 & NAS-NS-3058 \\
\hline QCBLK & Plutonium 238 & -0.26 & $\mathrm{pCi} / \mathrm{g}$ & 0.18 & NAS-NS-3058 \\
\hline QCBLK & Plutonium 238 & 0.001 & $\mathrm{pCi} / \mathrm{g}$ & 0.004 & NAS-NS-3058 \\
\hline QCBLK & Plutonium 239/240 & 0.001 & $\mathrm{pCi} / \mathrm{g}$ & 0.003 & NAS-NS-3058 \\
\hline QCBLK & Plutonium 239/240 & -0.002 & $\mathrm{pCi} / \mathrm{g}$ & 0.017 & NAS-NS-3058 \\
\hline QCBLK & Plutonium 239/240 & 0.02 & $\mathrm{pCi} / \mathrm{g}$ & 0.031 & NAS-NS-3058 \\
\hline QCBLK & Plutonium 239/240 & -0.001 & $\mathrm{pCi} / \mathrm{g}$ & 0.002 & NAS-NS-3058 \\
\hline QCBLK & Plutonium 239/240 & -0.21 & $\mathrm{pCi} / \mathrm{g}$ & 0.16 & NAS-NS-3058 \\
\hline QCBLK & Plutonium 239/240 & 0.001 & $\mathrm{pCi} / \mathrm{g}$ & 0.004 & NAS-NS-3058 \\
\hline QCBLK & Total Uranium & ND & $\mathrm{ug} / \mathrm{g}$ & NA & ASTM 5174-91 \\
\hline QCBLK & Uranium-234 & 1.23 & $\mathrm{pCi} / \mathrm{g}$ & 0.39 & NAS-NA-3050 \\
\hline QCBLK & Uranium-234 & 0.034 & $\mathrm{pCi} / \mathrm{g}$ & 0.037 & NAS-NA-3050 \\
\hline QCBLK & Uranium-234 & 0.006 & $\mathrm{pCi} / \mathrm{g}$ & 0.012 & NAS-NA-3050 \\
\hline QCBLK & Uranium-234 & 0.11 & $\mathrm{pCi} / \mathrm{g}$ & 0.21 & NAS-NA-3050 \\
\hline QCBLK & Uranium-234 & 0.05 & $\mathrm{pCi} / \mathrm{g}$ & 0.11 & NAS-NA-3050 \\
\hline QCBLK & Uranium-235/236 & 0.073 & $\mathrm{pCi} / \mathrm{g}$ & 0.086 & NAS-NA-3050 \\
\hline QCBLK & Uranium-235/236 & 0.022 & $\mathrm{pCi} / \mathrm{g}$ & 0.03 & NAS-NA-3050 \\
\hline QCBLK & Uranium-235/236 & 0.003 & $\mathrm{pCi} / \mathrm{g}$ & 0.01 & NAS-NA-3050 \\
\hline QCBLK & Uranium-235/236 & -0.027 & $\mathrm{pCi} / \mathrm{g}$ & 0.031 & NAS-NA-3050 \\
\hline QCBLK & Uranium-235/236 & 0.06 & $\mathrm{pCi} / \mathrm{g}$ & 0.14 & NAS-NA-3050 \\
\hline QCBLK & Uranium-238 & 0.99 & $\mathrm{pCi} / \mathrm{g}$ & 0.34 & NAS-NA-3050 \\
\hline QCBLK & Uranium-238 & 0 & $\mathrm{pCi} / \mathrm{g}$ & & NAS-NA-3050 \\
\hline QCBLK & Uranium-238 & 0 & $\mathrm{pCi} / \mathrm{g}$ & 0.001 & NAS-NA-3050 \\
\hline QCBLK & Uranium-238 & 0.29 & $\mathrm{pCi} / \mathrm{g}$ & 0.29 & NAS-NA-3050 \\
\hline QCBLK & Uranium-238 & 0 & $\mathrm{pCi} / \mathrm{g}$ & 0 & NAS-NA-3050 \\
\hline QCLCS & Americium 241 & 91 & $\%$ Recovery & NA & NAS-NS-3006 \\
\hline QCLCS & Americium 241 & 81 & $\%$ Recovery & NA & NAS-NS-3006 \\
\hline QCLCS & Americium 241 & 95 & $\%$ Recovery & NA & NAS-NS-3006 \\
\hline QCLCS & Americium 241 & 85 & $\%$ Recovery & NA & NAS-NS-3006 \\
\hline QCLCS & Americium 241 & 99 & $\%$ Recovery & NA & NAS-NS-3006 \\
\hline QCLCS & Americium 241 & 93 & $\%$ Recovery & NA & Gamma Spec \\
\hline QCLCS & Americium 241 & 90 & $\%$ Recovery & NA & Gamma Spec \\
\hline QCLCS & Cesium 137 & 105 & $\%$ Recovery & NA & Gamma Spec \\
\hline QCLCS & Cesium 137 & 104 & $\%$ Recovery & NA & Gamma Spec \\
\hline QCLCS & Cobalt 60 & 99 & $\%$ Recovery & NA & Gamma Spec \\
\hline QCLCS & Cobalt 60 & 103 & $\%$ Recovery & NA & Gamma Spec \\
\hline QCLCS & Plutonium 238 & 98 & $\%$ Recovery & NA & NAS-NS-3058 \\
\hline QCLCS & Plutonium 238 & 96 & $\%$ Recovery & NA & NAS-NS-3058 \\
\hline QCLCS & Plutonium 238 & 96 & $\%$ Recovery & NA & NAS-NS-3058 \\
\hline QCLCS & Plutonium 238 & 97 & $\%$ Recovery & NA & NAS-NS-3058 \\
\hline QCLCS & Plutonium 238 & 101 & $\%$ Recovery & NA & NAS-NS-3058 \\
\hline QCLCS & Plutonium 238 & 95 & $\%$ Recovery & NA & NAS-NS-3058 \\
\hline QCLCS & Plutonium 239/240 & 112 & $\%$ Recovery & NA & NAS-NS-3058 \\
\hline QCLCS & Plutonium $239 / 240$ & 101 & $\%$ Recovery & NA & NAS-NS-3058 \\
\hline QCLCS & Plutoniun & 104 & $\%$ Recovery & NA & NAS-NS-3058 \\
\hline
\end{tabular}


Appendix C

Isotopic Laboratory Analytical Results in Soil

First Characterization Event

\begin{tabular}{|c|c|c|c|c|c|}
\hline $\begin{array}{l}\text { Sample Number } \\
\text { QCLCS }\end{array}$ & $\begin{array}{l}\text { Isotope } \\
\text { Plutonium 239/240 }\end{array}$ & $\begin{array}{r}\text { Result } \\
99\end{array}$ & $\begin{array}{l}\text { Units } \\
\% \text { Recovery }\end{array}$ & $\begin{array}{l}2 \text { Sigma } \\
\text { NA }\end{array}$ & $\begin{array}{l}\text { Analytical Method } \\
\text { NAS-NS-3058 }\end{array}$ \\
\hline QCLCS & Plutonium $239 / 240$ & 106 & $\%$ Recovery & NA & NAS-NS-3058 \\
\hline QCLCS & Plutonium $239 / 240$ & 96 & $\%$ Recovery & NA & NAS-NS-3058 \\
\hline QCLCS & Total Uranium & 83 & $\%$ Recovery & NA & ASTM 5174-91 \\
\hline QCLCS & Uranium-234 & 103 & $\%$ Recovery & NA & NAS-NA-3050 \\
\hline QCLCS & Uranium-234 & 137 & $\%$ Recovery & NA & NAS-NA-3050 \\
\hline QCLCS & Uranium-234 & 126 & $\%$ Recovery & NA & NAS-NA-3050 \\
\hline QCLCS & Uranium-234 & 148 & $\%$ Recovery & NA & NAS-NA-3050 \\
\hline QCLCS & Uranium-234 & 124 & $\%$ Recovery & NA & NAS-NA-3050 \\
\hline QCLCS & Uranium-238 & 156 & $\%$ Recovery & NA & NAS-NA-3050 \\
\hline QCLCS & Uranium-238 & 125 & $\%$ Recovery & NA & NAS-NA-3050 \\
\hline QCLCS & Uranium-238 & 134 & $\%$ Recovery & NA & NAS-NA-3050 \\
\hline QCLCS & Uranium-238 & 132 & $\%$ Recovery & NA & NAS-NA-3050 \\
\hline QCLCS & Uranium-238 & 131 & $\%$ Recovery & NA & NAS-NA-3050 \\
\hline
\end{tabular}

Dup - Duplicate sample

RE - Sample reanalyzed (counted)

ND - Not Detected

NA - Not Applicable

milligram $/$ kilogram $(\mathrm{mg} / \mathrm{kg}$ ) or parts per million (ppm) 
Appendix C

Laboratory Results of Toxic Characteristic Leaching Procedures

(Hot Spot Samples)

Second Characterization Event

Sample Number

Analyte

Units

Result Qualifiers

Detection

DT00100

Arsenic

DT00100

Barium

DT00100

Cadmium

DT00100

DT00100

Chromium

Lead

DT00100

DT00100

Selenium

Silver

DT00100

Mercury

DT00102

Arsenic

DT00102

Barium

Cadmium

DT00102

Chromium

Lead

DT00102

DT00102

Selenium

Silver

DT00102

Mercury

DT00103

Arsenic

DT00103

Barium

DT00103

Cadmium

DT00103

DT00103

Chromium

Lead

DT00103

DT00103

DT00103

Selenium

Silver

Mercury

DT00104

Arsenic

DT00104

Barium

DT00104

Cadmium

DT00104

Chromium

DT00104

Lead

DT00104

Selenium

DT00104

Silver

DT00104

Mercury

Extraction Blank Arsenic

Extraction Blank Barium

Extraction Blank Cadmium

Extraction Blank Chromium

Extraction Blank Lead

Extraction Blank Selenium

Extraction Blank Silver

Extraction Blank Mercury

$\mathrm{mg} /$

$\mathrm{mg} / 1$

$\mathrm{mg} / \mathrm{l}$

$\mathrm{mg} / \mathrm{l}$

$\mathrm{mg} / \mathrm{l}$

$\mathrm{mg} / \mathrm{l}$

$\mathrm{mg} / \mathrm{l}$

$\mathrm{mg} / \mathrm{l}$

0.0078

Limit

$\mathrm{mg} / \mathrm{l}$

$\mathrm{mg} / \mathrm{l}$

$\mathrm{mg} / \mathrm{l}$

$\mathrm{mg} / \mathrm{l}$

$\mathrm{mg} / \mathrm{l}$

0.4

0.005

0.0024

0.01

0.0047

0.005

U

0.01

0.0077

0.003

0.005

0.0096

0.01

0.0001

U

0.0002

$\mathrm{mg} / \mathrm{l}$

$\mathrm{mg} / \mathrm{l}$

0.0074

0.005

0.43

0.01

0.0024

0.005

0.0047

0.01

0.005

0.003

0.0096

0.005

$\mathrm{mg} / \mathrm{l}$

0.0041

0.01

0.00029

0.0002

$\mathrm{mg} /$

0.0092

0.005

$\mathrm{mg} / \mathrm{l}$

0.39

$\mathrm{mg} / \mathrm{l}$

$\mathrm{mg} / \mathrm{l}$

0.0024

0.0047

0.002

0.01

$\mathrm{mg} / \mathrm{l}$

0.0091

$\mathrm{mg} / \mathrm{l}$

0.0041

$\mathrm{mg} / \mathrm{l}$

0.00012

0.005

0.01

0.003

0.005

$\mathrm{mg} / \mathrm{l}$

0.01

$\mathrm{mg} /$

0.0061

0.005

$\mathrm{mg} / \mathrm{l}$

0.044

0.01

$\mathrm{mg} / \mathrm{l}$

0.0024

0.005

$\mathrm{mg} / \mathrm{l}$

0.0047

0.01

$\mathrm{mg} / \mathrm{l}$

0.0022

0.003

$\mathrm{mg} / \mathrm{l}$

0.0096

0.005

0.0041

0.01

$\mathrm{mg} / \mathrm{l}$

0.00016

0.0002

$m g / l$

$\mathrm{mg} / \mathrm{l}$

0.003

0.005

0.0034

0.01

$\mathrm{mg} / \mathrm{l}$

0.0024

0.005

$\mathrm{mg} / \mathrm{l}$

0.0047

0.01

$\mathrm{mg} / \mathrm{l}$

0.0015

$\mathrm{mg} / \mathrm{l}$

0.0035

0.003

$\mathrm{mg} / \mathrm{I}$

0.0041

0.005

$\mathrm{mg} / \mathrm{l}$

0.0001

0.01

0.0002 
Appendix C

Laboratory Results of Toxic Characteristic Leaching Procedures

(Hot Spot Samples)

Second Characterization Event

\begin{tabular}{|c|c|c|c|c|c|}
\hline Sample Number & Analyte & Units & Result & Qualifiers & $\begin{array}{l}\text { Detection } \\
\text { Limit }\end{array}$ \\
\hline QC Blank & Arsenic & $\mathrm{mg} / \mathrm{l}$ & 0.0018 & $U$ & 0.005 \\
\hline QC Blank & Barium & $\mathrm{mg} / \mathrm{l}$ & 0.0013 & $\mathrm{U}$ & 0.01 \\
\hline QC Blank & Cadmium & $\mathrm{mg} / \mathrm{l}$ & 0.0024 & U & 0.005 \\
\hline QC Blank & Chromium & $\mathrm{mg} / \mathrm{l}$ & 0.0047 & $\mathrm{U}$ & 0.01 \\
\hline QC Blank & Lead & $\mathrm{mg} / \mathrm{l}$ & 0.0011 & $\mathrm{U}$ & 0.003 \\
\hline QC Blank & Selenium & $\mathrm{mg} / \mathrm{l}$ & 0.0025 & $U$ & 0.005 \\
\hline QC Blank & Silver & $\mathrm{mg} / \mathrm{l}$ & 0.0041 & $\mathrm{U}$ & 0.01 \\
\hline QC Blank & Mercury & $\mathrm{mg} / \mathrm{l}$ & 0.0001 & $U$ & 0.0002 \\
\hline QC Blank & Arsenic & $\mathrm{mg} / \mathrm{l}$ & 0.0018 & $U$ & 0.005 \\
\hline QC Blank & Barium & $\mathrm{mg} / \mathrm{l}$ & 0.0013 & B & 0.01 \\
\hline QC Blank & Cadmium & $\mathrm{mg} / \mathrm{l}$ & 0.0024 & $U$ & 0.005 \\
\hline QC Blank & Chromium & $\mathrm{mg} / \mathrm{l}$ & 0.0047 & $u$ & 0.01 \\
\hline QC Blank & Lead & $\mathrm{mg} / \mathrm{l}$ & 0.0011 & U & 0.003 \\
\hline QC Blank & Selenium & $\mathrm{mg} / \mathrm{l}$ & 0.0025 & U & 0.005 \\
\hline QC Blank & Silver & $\mathrm{mg} / \mathrm{l}$ & 0.0041 & $\mathrm{U}$ & 0.01 \\
\hline QC Blank & Mercury & $\mathrm{mg} / 1$ & 0.0001 & $\mathrm{U}$ & 0.0002 \\
\hline
\end{tabular}

$\begin{array}{lllr}\text { QCLCS } & \text { Arsenic } & \text { percent } & 108 \\ \text { QCLCS } & \text { Barium } & \text { percent } & 98 \\ \text { QCLCS } & \text { Cadmium } & \text { percent } & 105 \\ \text { QCLCS } & \text { Chromium } & \text { percent } & 104 \\ \text { QCLCS } & \text { Lead } & \text { percent } & 102 \\ \text { QCLCS } & \text { Selenium } & \text { percent } & 108 \\ \text { QCLCS } & \text { Silver } & \text { percent } & 85 \\ \text { QCLCS } & \text { Mercury } & \text { percent } & 111 \\ & & & \\ \text { QCLCS } & \text { Arsenic } & \text { percent } & 110 \\ \text { QCLCS } & \text { Barium } & \text { percent } & 101 \\ \text { QCLCS } & \text { Cadmium } & \text { percent } & 107 \\ \text { QCLCS } & \text { Chromium } & \text { percent } & 106 \\ \text { QCLCS } & \text { Lead } & \text { percent } & 105 \\ \text { QCLCS } & \text { Selenium } & \text { percent } & 105 \\ \text { QCLCS } & \text { Silver } & \text { percent } & 86 \\ \text { QCLCS } & \text { Mercury } & \text { percent } & 113\end{array}$

Qualifiers

$U$ - Analyte was analyzed for but not detected

B - Reported value was obtained from a reading that was less than ther required detection limit but greater than the intrument detection limit.

milligram/kilogram (mg/kg) or parts per million (ppm)

microgram/kilogram (ug/kg) or parts per billion $(\mathrm{ppb})$ 
Appendix C

Isotopic Laboratory Analytical Results in Soil (Hot Spot Samples)

Second Characterization Event

Sample Number

\section{DT00100 \\ DT00100 \\ DT00100 \\ DT00100}

$\begin{array}{ll}\text { DT00100 Dup } & \text { Plutonium 239/240 } \\ \text { DT00100 Dup } & \text { Plutonium 238 } \\ \text { DT00100 Dup } & \text { Amercium 241 } \\ \text { DT00100 Dup } & \text { Total Uranium }\end{array}$

\section{DT00101 \\ DT00101 \\ DT00101 \\ DT00101}

DT00102

DT00102

DT00102

DT00102

DT00103

DT00103

DT00103

DT00103

DT00104

DT00104

DT00104

DT00104

DT00105

DT00105

DT00105

DT00105

QC Blank

QC Blank

QC Blank

QC Blank
Plutonium 239/240

Plutonium 238

Amercium 241

Total Uranium

Plutonium 239/240

Plutonium 238

Amercium 241

Total Uranium

Plutonium 239/240

Plutonium 238

Amercium 241

Total Uranium

Plutonium 239/240

Plutonium 238

Amercium 241

Total Uranium

Plutonium 239/240

Plutonium 238

Amercium 241

Total Uranium

Plutonium 239/240

Plutonium 238

Amercium 241

Total Uranium

Plutonium 239/240

Plutonium 238

Amercium 241

Total Uranium

Plutonium 239/240

Plutonium 238

Amercium 241

Total Uranium
Units

pCi/g

$\mathrm{pCi} / \mathrm{g}$

$\mathrm{pCi} / \mathrm{g}$

ppm

$\mathrm{pCi} / \mathrm{g}$

$\mathrm{pCi} / \mathrm{g}$

$\mathrm{pCi} / \mathrm{g}$

ppm

$\mathrm{pCi} / \mathrm{g}$

$\mathrm{pCi} / \mathrm{g}$

$\mathrm{pCi} / \mathrm{g}$

ppm

$\mathrm{pCi} / \mathrm{g}$

$\mathrm{pCi} / \mathrm{g}$

$\mathrm{pCi} / \mathrm{g}$

ppm

pCi/g

$\mathrm{pCi} / \mathrm{g}$

$\mathrm{pCi} / \mathrm{g}$

ppm

$\mathrm{pCi} / \mathrm{g}$

$\mathrm{pCi} / \mathrm{g}$

pCi/g

ppm

$\mathrm{pCi} / \mathrm{g}$

$\mathrm{pCi} / \mathrm{g}$

$\mathrm{pCi} / \mathrm{g}$

ppm

$\mathrm{pCi} / \mathrm{g}$

$\mathrm{pCi} / \mathrm{g}$

$\mathrm{pCi} / \mathrm{g}$

ppm

$\%$ recovery

$\%$ recovery

$\%$ recovery

$\%$ recovery
Result

12000

90

734

3.5

10600

101

656

3.59

10800

95

567

2.63

998

9.45

64.6

3.92

11900

91

783

3.41

775

10.9

29.6

2.55

183

6.1

10.1

2.12

1.27

0.058

0.1

ND

92

99

98

99

2-sigma MDA

2030

2

22.5

163

0.37

0.005

1870

27

154

0.38

2010

28.5

133

0.27

200

7.51

25

0.41

2060

23.8

172

0.36

158

8.2

12.1

0.27

5.1

0.005

QCLCS

Manimum Detection Activity (MDA)

Dup - Duplicate sample

milligram/kilogram $(\mathrm{mg} / \mathrm{kg}$ ) or parts per million (ppm) 



\section{Appendix D}

\section{Bechtel Nevada, Remote Sensing Laboratory Report on the Second and Third Characterization Events}



DOE/NV/11718-013

UC-702

LABORATORY

OPERATED FOR THE U.S.

MARCH 1996

\title{
IN SITU RADIOLOGICAL SURVEYING AT THE DOUBLE TRACKS SITE
}

\author{
NELLIS AIR FORCE RANGE \\ TONOPAH, NEVADA
}




\section{DISCLAIMER}

This report was prepared as an account of work sponsored by an agency of the United States Government. Neither the United States Government nor any agency thereof, nor any of their employees, makes any warranty, express or implied, or assumes any legal liability or responsibility for the accuracy, completeness, or usefulness of any information, apparatus, product, or process disclosed, or represents that its use would not infringe privately owned rights. Reference herein to any specific commercial product, process, or service by trade name, trademark, manufacturer, or otherwise, does not necessarily constitute or imply its endorsement, recommendation, or favoring by the United States Government or any agency thereof. The views and opinions of authors expressed herein do not necessarily state or reflect those of the United States Government or any agency thereof.

This report has been reproduced directly from the best available copy.

Available to DOE and DOE contractors from the Office of Scientific and Technical Information, P.O. Box 62, Oak Ridge, Tennessee 37831; prices available from (615) 576-8401.

Available to the public from the National Technical Information Service, U.S. Department of Commerce, 5285 Port Royal, Springfield, Virginia 22161. 


\title{
IN SITU RADIOLOGICAL SURVEYING ATTHE DOUBLE TRACKS SITE
}

\author{
NELLIS AIR FORCE RANGE \\ TONOPAH, NEVADA
}

DATE OF SURVEY: APRIL 10-13, 1995, AND JUNE 5-9, 1995

S. R. Riedhauser

W. J. Tipton

Project Scientists

\section{REVIEWED BY}

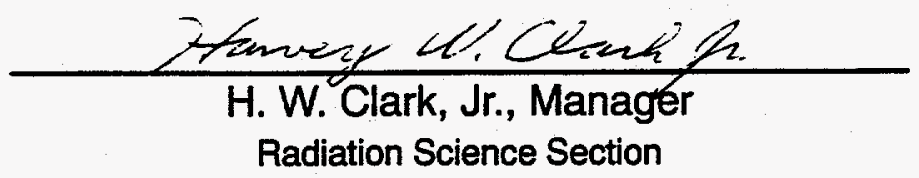

This Document is UNCLASSIFIED

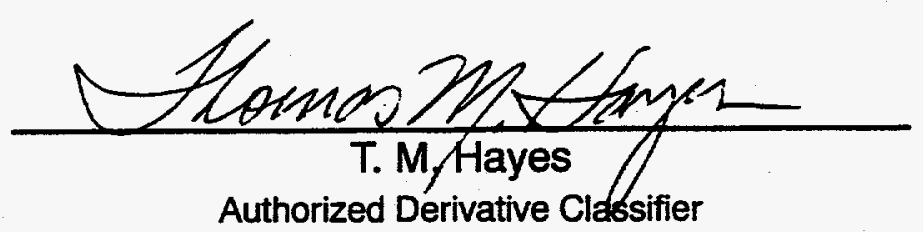

This work was performed for the United States Department of Energy by Bechtal Nevada under Contract Number DE-AC08-96NV11718 and by EG\&G/EM under Contract Number DE-AC08-93NV11265. 



\begin{abstract}
A team from the Remote Sensing Laboratory conducted a series of in situ radiological measurements at the Double Tracks site on the Nellis Air Force Range just east of Goldfield, Nevada, during the periods of April 10-13 and June 5-9, 1995. The survey team measured the terrestrial gamma radiation at the site to determine the levels of natural and man-made radiation. This site includes the areas covered by previous surveys conducted from 1962 through 1993.

The main purpose of the first expedition was to assess several new techniques for characterizing sites with dispersed plutonium. The two purposes of the second expedition were to characterize the distribution of transuranic contamination (primarily plutonium) at the site by measuring the gamma rays from americium-241 and to assess the performance of the two new detector platforms. Both of the new platforms performed well, and the characterization of the americium-241 activity at the site was completed.

Several plots compare these ground-based system measurements and the 1993 aerial data. The agreement is good considering the systems are characterized and calibrated through independent means.

During the April expedition, several methods for measuring the depth distribution of americium-241 in the field were conducted as a way of quickly and reliably obtaining depth profiles without the need to wait for laboratory analysis. Two of the methods were not very effective, but the results of the third method appear very promising.
\end{abstract}





\section{CONTENTS}

Abstract

\section{Sections}

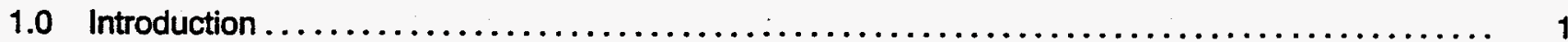

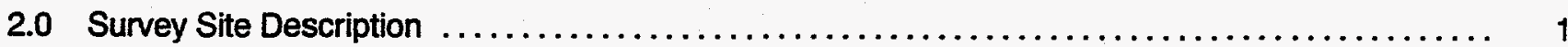

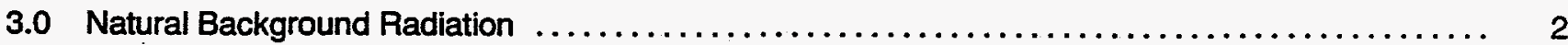

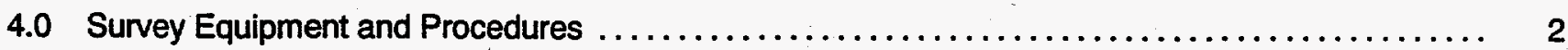

4.1 Experiment \#1 (April)-HPGe In Situ Measurements $\ldots \ldots \ldots \ldots \ldots \ldots \ldots \ldots \ldots \ldots \ldots$

4.1.1 Suburban Versus Tripod Measurements $\ldots \ldots \ldots \ldots \ldots \ldots \ldots \ldots \ldots \ldots \ldots \ldots \ldots$

4.1.2. Measurements South of the Exclusion Fence $\ldots \ldots \ldots \ldots \ldots \ldots \ldots \ldots \ldots \ldots$

4.2 Experiment \#2 (April)—Pu:Am Ratio Measurements $\ldots \ldots \ldots \ldots \ldots \ldots \ldots \ldots \ldots \ldots \ldots \ldots \ldots$

4.3 Experiment \#3 (April)-Depth Profiling Measurements $\ldots \ldots \ldots \ldots \ldots \ldots \ldots \ldots \ldots \ldots \ldots$

4.3.1 Side Wall Measurements with Thermoluminescent Dosimetry Material . .......... 6

4.3.2 Comparison Between the Pu X-Rays and the ${ }^{241}$ Am Gamma Ray $\ldots \ldots \ldots \ldots \ldots \ldots$

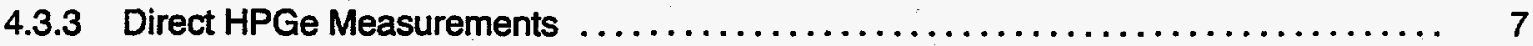

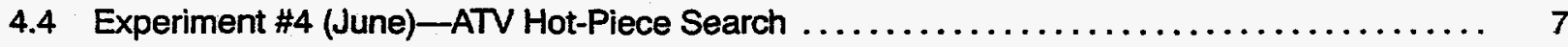

4.5 Experiment \#5 (June) —Kiwi Survey Measurements $\ldots \ldots \ldots \ldots \ldots \ldots \ldots \ldots \ldots \ldots \ldots \ldots$

4.6 Experiment \#6 (June) - HPGe In Situ Measurements ...................... 9

4.7 Experiment \#7 (June) - Hot-Piece Activity Measurements $\ldots \ldots \ldots \ldots \ldots \ldots \ldots \ldots \ldots$

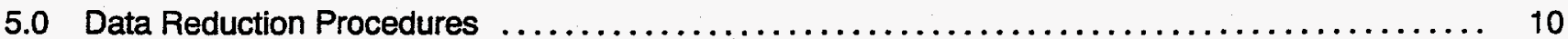

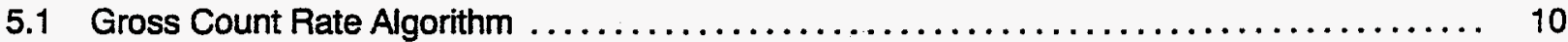

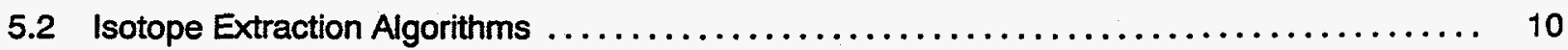

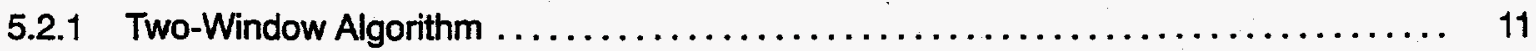

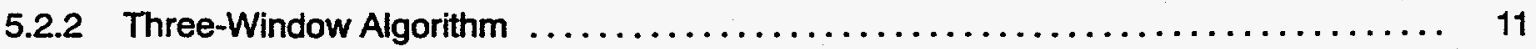

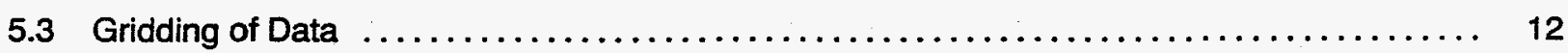

5.4 Count Rate Conversion to Soil Activity Concentration $\ldots \ldots \ldots \ldots \ldots \ldots \ldots \ldots \ldots \ldots \ldots \ldots \ldots \ldots$

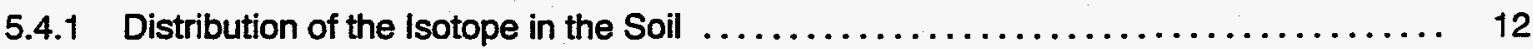

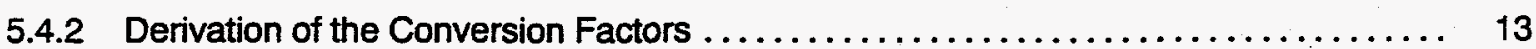

5.4.3 Conversion Factors for Selected Isotopes in the Soil $\ldots \ldots \ldots \ldots \ldots \ldots \ldots \ldots \ldots$

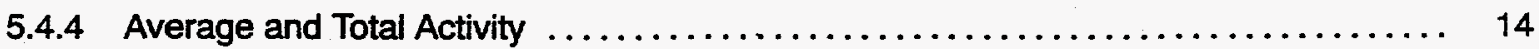

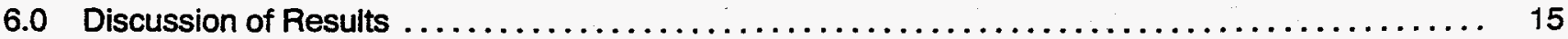


6.1 Experiment \#1 (April)-HPGe In Situ Measurements $\ldots \ldots \ldots \ldots \ldots \ldots \ldots \ldots \ldots \ldots \ldots \ldots$

6.1.1 Suburban Versus Tripod Measurements $\ldots \ldots \ldots \ldots \ldots \ldots \ldots \ldots \ldots \ldots \ldots \ldots \ldots \ldots$

6.1.2 Measurements South of the Exclusion Fence $\ldots \ldots \ldots \ldots \ldots \ldots \ldots \ldots \ldots \ldots \ldots .18$

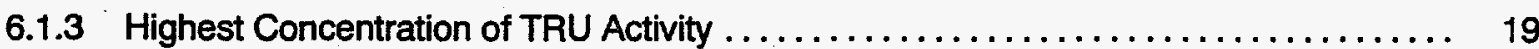

6.2 Experiment \#2 (April)—Pu:Am Ratio Measurements $\ldots \ldots \ldots \ldots \ldots \ldots \ldots \ldots \ldots \ldots \ldots . \ldots \ldots$

6.3 Experiment \#3 (April)—Depth Profiling Measurements $\ldots \ldots \ldots \ldots \ldots \ldots \ldots \ldots \ldots \ldots . \ldots \ldots$

6.3.1 Side Wall Measurements with TLD Material $\ldots \ldots \ldots \ldots \ldots \ldots \ldots \ldots \ldots \ldots \ldots \ldots \ldots$

6.3.2 Comparison Between the Pu X-Rays and the ${ }^{241}$ Am Gamma Ray $\ldots \ldots \ldots \ldots \ldots .23$

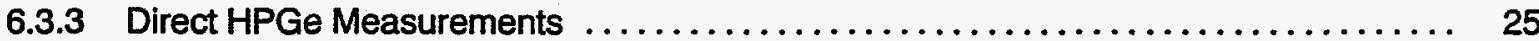

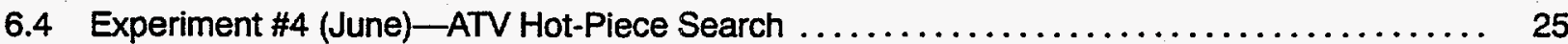

6.5 Experiment \#5 (June) - Kiwi Survey Measurements ........................ 25

6.6 Experiment \#6 (June)-HPGe In Situ Measurements $\ldots \ldots \ldots \ldots \ldots \ldots \ldots \ldots \ldots \ldots \ldots \ldots$

6.7 Experiment \#7 (June) - Hot-Piece Activity Measurements $\ldots \ldots \ldots \ldots \ldots \ldots \ldots \ldots \ldots \ldots$

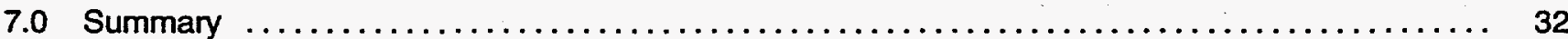

\section{Figures}

1 Suburban Vehicle with HPGe Detector on Mast $\ldots \ldots \ldots \ldots \ldots \ldots \ldots \ldots \ldots \ldots \ldots \ldots \ldots \ldots \ldots$

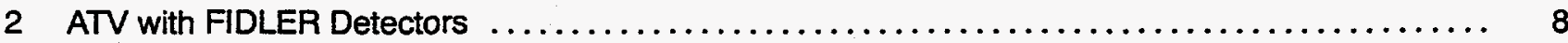

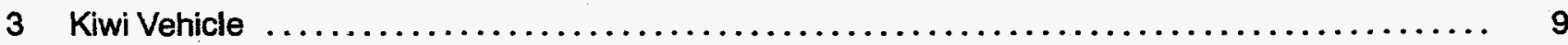

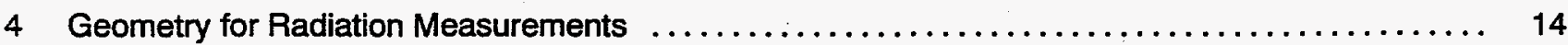

5 Measurement Locations of the Suburban System (April) $\ldots \ldots \ldots \ldots \ldots \ldots \ldots \ldots \ldots \ldots \ldots \ldots \ldots \ldots \ldots$

6 Suburban Versus Tripod Measurements-First Location $\ldots \ldots \ldots \ldots \ldots \ldots \ldots \ldots \ldots \ldots \ldots \ldots .19$

7 Suburban Versus Tripod Measurements-Second Location $\ldots \ldots \ldots \ldots \ldots \ldots \ldots \ldots \ldots \ldots \ldots \ldots$

8 Suburban Versus Tripod Measurements-Third Location $\ldots \ldots \ldots \ldots \ldots \ldots \ldots \ldots \ldots \ldots \ldots \ldots$

9 Tripod Measurements Made South of the Double Tracks Fence (April) $\ldots \ldots \ldots \ldots \ldots \ldots \ldots \ldots .21$

10 Kiwi Point-by-Point Gross Count and TRU Activity Levels $\ldots \ldots \ldots \ldots \ldots \ldots \ldots \ldots \ldots \ldots \ldots \ldots$

11 Kiwi $30-f t$ Gridded and 30-ft Averaged Gross Count Data $\ldots \ldots \ldots \ldots \ldots \ldots \ldots \ldots \ldots \ldots \ldots \ldots$

12 Kiwi $30-\mathrm{ft}$ Gridded and 30 -ft Averaged TRU Activities $\ldots \ldots \ldots \ldots \ldots \ldots \ldots \ldots \ldots \ldots \ldots \ldots \ldots \ldots \ldots \ldots \ldots \ldots$

13 Kiwi $30-f t$ Gridded and $270-f t$ Averaged TRU Activities $\ldots \ldots \ldots \ldots \ldots \ldots \ldots \ldots \ldots \ldots \ldots \ldots$

14 Measurement Locations of the Suburban System (June) $\ldots \ldots \ldots \ldots \ldots \ldots \ldots \ldots \ldots \ldots \ldots \ldots$

B-1 Soil Surface Alpha Map with $\mathrm{CaSO}_{4} \mathrm{Tm}$ (Grain Size 10 to 40 microns) ................. 40 


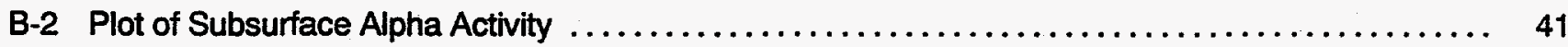

B-3 This Plot is Derived from Figure B-2 and Represents the Average Net

Signal per Minute Integrated over the TLD Sheet Portion that was Subsurface

\section{Tables}

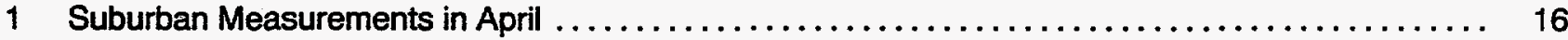

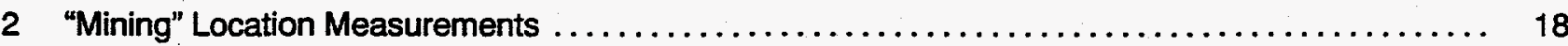

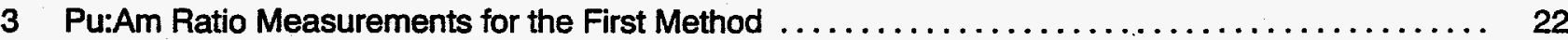

4 Pu:Am Ratio Measurements for the Second Method $\ldots \ldots \ldots \ldots \ldots \ldots \ldots \ldots \ldots \ldots \ldots \ldots \ldots, 23$

5 Pu:Am Ratio Calculations from Initial Composition $\ldots \ldots \ldots \ldots \ldots \ldots \ldots \ldots \ldots \ldots \ldots \ldots \ldots \ldots \ldots . \ldots \ldots$

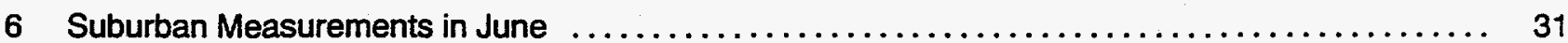

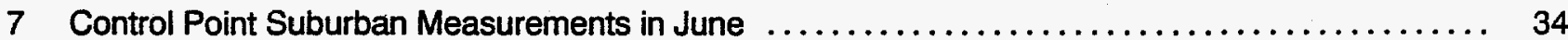

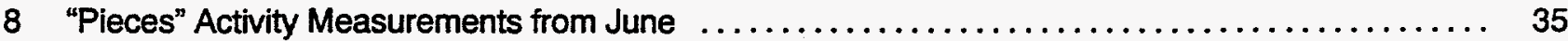

9 Soil Sample Activity Measurements from June $\ldots \ldots \ldots \ldots \ldots \ldots \ldots \ldots \ldots \ldots \ldots \ldots \ldots \ldots \ldots \ldots \ldots$

\section{Appendix}

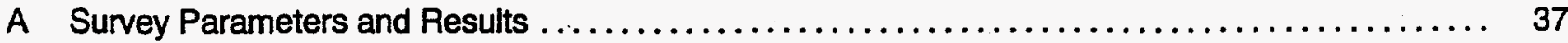

B In Situ Measurement of Environmental Alpha Activity at Very High

Spatial Resolution and Sensitivity

References 



\subsection{INTRODUCTION}

The U.S. Department of Energy (DOE) maintains the Remote Sensing Laboratory (RSL), which provides several systems for measuring terrestrial radiation. In addition to the aerial radiological surveillance systems mounted in either BO-105 helicopters or B-200 airplanes, RSL has several systems for ground-based measurements. During these expeditions, RSL was operated by EG\&G Energy Measurements, Inc., (EG\&G/EM) under contract to DOE, with bases of operation at Nellis Air Force Base in Las Vegas, Nevada, and at Andrews Air Force Base near Washington, D.C.

The Double Tracks site was previously surveyed by the RSL from helicopter platforms in 1977 and 1993. The DOE requested that International Technology Corporation (IT) characterize the nature and extent of contamination, so that corrective action options could be evaluated. If necessary, the site would be cleaned up prior to its release back to the U.S. Air Force. Teams from the RSL participated in two ground-based expeditions to the Double Tracks site in the first half of 1995.

The first RSL expedition was performed from April 10-13, 1995, using the RSL's Chevrolet Suburban vehicle with a high-purity germanium (HPGe) detector mounted on its $7.5-\mathrm{m}$ (25-ft) mast and two tripod HPGe detector systems. The objectives of this survey were to gather in situ radiological data with a set of different instruments at a series of locations within the Double Tracks exclusion zone (fenced area) and to compare this data with similar data collected by previous aerial surveys and by systems fielded by IT and Reynolds Electrical and Engineering Co, Inc. (REECo).

Based on the information acquired during the first trip, a second expedition took place during the week of June 5-9, 1995, when two new detector platforms were field tested. One platform used a set of three Field Instrument for Detection of Low-Energy Radiation (FIDLER) detectors mounted on the front of an all-terrain vehicle (ATV) about one-half meter above the ground. This system was used to search in a systematic manner for pieces of metal which had plutonium (Pu) adhering to their surfaces. The second detector platform fielded during this trip was the standard RSL aerial detection and recording system adapted to a ground-based vehicle and nicknamed the Kiwi. Specifically, a set of sodium iodide (Nal) detectors were mounted on the rear of a Chevrolet Suburban vehicle. As the vehicle moved, individual gamma-ray spectra were recorded each second to provide complete coverage of the Double Tracks area. The field-of-view of the detector system was approximately $3 \mathrm{~m}$ (10 ft) in diameter.

For consistency between this report and the Double Tracks Test Site Characterization Report being prepared by IT, the phrase "hot fragment" will refer to any piece of radioactive material larger than $5 \mu \mathrm{m}(0.0002 \mathrm{in})$. Pieces smaller than this size will be called "hot particles." The term "piece" will refer to either a fragment or a particle. Any piece which is visible to the unaided eye is a fragment.

\subsection{SURVEY SITE DESCRIPTION}

The Double Tracks site is situated on Stonewall Flat (an arid plain) on the Nellis Air Force Range (NAFR) and is about $25 \mathrm{~km}$ ( $16 \mathrm{mi}$ ) east of Goldfield and $35 \mathrm{~km}$ (22 mi) southeast of Tonopah, Nevada. ${ }^{1}$ Access is through the Tonopah Test Range (TTR). The Double Tracks site has an elevation of approximately $1,500 \mathrm{~m}$ $(4,900 \mathrm{ft})$. The area is mostly sandy soil with a thin layer of small gravel on the surface and is covered with small shrubs and some grass. The Double Tracks test involved the detonation of a high explosive near an assembly of Pu and depleted uranium (U) to study the means of dispersal of transuranic (TRU) elements and their uptake in animals. The quantity of depleted $U$ was 4-5 times the quantity of Pu. The test was conducted at 2:55 a.m. on May 15, 1963.

The five-sided fence currently surrounding the Double Tracks site forms the radiation exclusion zone of approximately 18 hectares ( 2 million $\mathrm{ft}^{2}$ ). This fence was established several years after the test and the boundary was based on the gamma radiation levels measured by a set of FIDLER detectors. After the test, soil from an area near the blast was pushed on top of the original concrete platform to produce a mound about $1.3 \mathrm{~m} \mathrm{(4ft)} \mathrm{high.} \mathrm{An} \mathrm{older,} \mathrm{almost} \mathrm{circu-}$ lar fence still existed (until the June expedition) around the mound of soil at ground zero $(G Z)$ and extended 30-40 m (100-130 ft) from GZ.

Previous semiannual ground-based surveys of the Double Tracks site were conducted by REECo for several years after the tests. ${ }^{2}$ These surveys consisted of air samples, surface swipes, and water examination, as well as gas proportional counter measurements made in the four compass directions at $30-\mathrm{m} \cdot(100-\mathrm{ft})$ intervals from the (what is now inner) fence. As described in the REECo report, these measurements were strongly influenced by high-activity debris near the measurement locations. 
RSL performed aerial surveys of the Double Tracks site using helicopters in February 1977 and December 1993 . The 1977 survey was conducted at a 30-m (100-ft) altitude using a line spacing of $61 \mathrm{~m}(200 \mathrm{ft}) .^{3}$ The 1993 survey was also conducted at a height of $30 \mathrm{~m}$ but used a line spacing of $46 \mathrm{~m}(150 \mathrm{ft}) .{ }^{4} \mathrm{~A}$ separate report presents additional processing of the 1993 data to improve the minimum detectable activity for americium-241 ( $\left.{ }^{241} \mathrm{Am}\right) .{ }^{5}$ However, this additional processing had the deleterious side effect of enlarging the footprint of the measurement system and decreasing the spatial resolution of the data thus distorting the size of the area which needed remediation.

\subsection{NATURAL BACKGROUND RADIATION}

Many factors - both radiation from sources of interest to the current investigation, radiation from sources not of current interest, and electrical noise-contribute to forming the total measured gamma-ray energy spectrum. These components can be summarized as the five terms in the following equation:

$$
\left[\begin{array}{c}
\text { Measured } \\
\text { Radiation } \\
\text { Spectrum }
\end{array}\right] \begin{aligned}
& + \text { Man-Made Rerrestrial Radionuclides } \\
& =+ \text { Airborne Radon } \\
& + \text { Cosmic Rays } \\
& + \text { Equipment Contributions }
\end{aligned}
$$

The term "natural background radiation" is generally considered to comprise three of the terms in the above equation; namely, natural terrestrial radionuclides, airborne radon (Rn) gas and its daughter products, and cosmic rays. The man-made radionuclides, such as cobalt-60 $\left({ }^{60} \mathrm{Co}\right)$ and cesium-137 $\left({ }^{137} \mathrm{Cs}\right)$, produced through actions by man are generally the components of the radiation field of most interest. The final term in this equation represents all sources of "noise" in the final spectrum, ranging from electrical noise in the electronics processing the detector signals to radiation sources inherent in the detectors and other measurement equipment.

Long-lived radionuclides present in the earth's crust are usually the largest source of background radiation. Naturally occurring isotopes found in the soil and bedrock consist mainly of radionuclides from the $\mathrm{U}$ and thorium (Th) decay chains and radioactive potassium (K). The most prominent natural isotopes usually seen in spectra are potassium $-40(40 \mathrm{~K})$
$(0.012 \%$ of natural $\mathrm{K})$, thallium-208 $\left({ }^{208} \mathrm{TI}\right)$ and actinjum-228 $\left({ }^{228} \mathrm{Ac}\right)$ (daughters in the ${ }^{232} \mathrm{Th}$ chain), and bismuth-214 (214 $\mathrm{Bi})$ (a daughter in the ${ }^{238} \mathrm{U}$ chain). Although it is considered a man-made radionuclide, a measurable amount of ${ }^{137} \mathrm{Cs}$ is found throughout the world (initially as a surface deposition and then, over time, migrating several inches into the soil) as a result of the atmospheric testing of nuclear weapons. These naturally occurring isotopes typically contribute 1-15 $\mu R / h$ to the background radiation field. ${ }^{6}$

Rn (a noble gas) is a member of both the $U$ and Th decay chains. After being created in the soil from its parent isotope, Rn can diffuse through the soil and become airborne. While the isotopes of $\mathrm{Rn}$ have relatively short half-lives, their daughters may become attached to dust particles in the atmosphere and contribute to the airborne radiation field until the dust eventually settles to the ground. The contribution of $R n$ and its daughters to the background radiation field depends on several factors, including the concentration of $U$ and Th isotopes in the soil, the permeability of the soil, and the meteorological conditions at the time of measurement. Typically, airborne radiation from $\mathrm{Rn}$ and its daughters contributes $1-10 \%$ of the natural background radiation level.

Cosmic rays entering the earth's atmosphere are a third source of background radiation. High-energy cosmic rays (principally protons, alpha particles, and some heavier nuclei) interact predominantly with atoms in the upper atmosphere to produce showers of secondary radiation. The contribution of cosmic rays to the background radiation field varies with elevation above mean sea level and with geomagnetic latitude. The earth's magnetic field traps some of the cosmic rays, so a larger fraction of them reaches the poles than the equator. In the continental U.S., values range from $3.3 \mu \mathrm{R} / \mathrm{h}$ at sea level to $12 \mu \mathrm{R} / \mathrm{h}$ at an elevation of $3,000 \mathrm{~m}(10,000 \mathrm{ft}) .^{7}$ For surveys in the continentalU.S., the dependence on geomagnetic latitude is very small and the elevation of the survey is the predominant determinant of the cosmic ray flux.

\subsection{SURVEY EQUIPMENT AND PROCEDURES}

Each radioactive isotope emits one or more types of radiation when it decays-alpha particles, beta particles, gamma rays, or X-rays. More importantly, these decay products have a specific energy which helps to indicate what parent isotope emitted it. The mix of Pu isotopes present at Double Tracks decay either by the emission of an alpha particle (which is 
impossible to detect more than a few centimeters away) or by the emission of a very low-energy beta particle (which is also very difficult to detect). In addition to these particles, $\mathrm{Pu}$ emits some low-energy $\mathrm{X}$-rays and, at a very low rate, some gamma rays. Nearly all systems used to search for Pu rely on detecting the $60-\mathrm{keV}$ gamma ray emitted by ${ }^{241} \mathrm{Am}$, the decay product of plutonium-241 ( $\left.{ }^{241} \mathrm{Pu}\right)$. These gamma rays are relatively easy to detect, even from aerial detection systems $30-50 \mathrm{~m}$ (100-150 ft) above the ground, and are much more abundant than the gamma rays emitted directly from the Pu decays.

The Nal detectors (used in the Kiwi system and by previous aerial surveys) can be made with large areas and volumes which allow them to efficiently collect most of the gamma rays incident on their crystal face. However, their energy resolution is relatively poor, so the ability to identify specific gamma-ray energies and, therefore, specific isotopes is limited to areas containing only a few isotopes. The HPGe detectors (used on the Suburban system and on the tripods) are much smaller in size than the $\mathrm{Nal}$ detectors. Consequently, they collect gamma rays at a much lower rate. Their advantage is their high-energy resolution, which makes the isotopic identification relatively easy even in areas containing many isotopes.

The above discussion regarding the identification of isotopes from the measured gamma-ray energies assumes that all of the initial gamma-ray energy is collected by the detector. This is not often the case. Many of the gamma rays emitted by an isotope will be scattered (by soil or air or inside the detector) and lose some of their energy, breaking the correlation between a specific energy and a specific isotope. This is a process known as Compton scattering, and it creates a smoothly varying background within the energy spectrum. Statistical fluctuations at a given energy due to this Compton background increase the uncertainty in how many gamma rays of this initial energy were detected. Thus the uncertainty in the amount of an isotope present during a measurement increases with the increase in the Compton background.

Unlike alpha and beta particles, gamma rays can travel large distances through the atmosphere. With a detector suspended $1 \mathrm{~m}(3 \mathrm{ft})$ above a perfectly flat ground, $50 \%$ of the detected $60-\mathrm{keV}{ }^{241} \mathrm{Am}$ gamma rays will originate from more than $6 \mathrm{~m}(20 \mathrm{ft})$ away. Typical ground-roughness effects will decrease the number of gamma rays from large distances, but a 6- $m$ radius circle is still not a very localized area. When a measurement must be made of a well-defined spot on the ground, a collimator must be used to shield the detector from gamma rays emitted from areas outside this one spot. Generally, limiting the field-of-view requires the use of a large quantity of very dense material. However, for $60-\mathrm{keV}$ gamma rays, this can be accomplished by using approximately $3 \mathrm{~mm}(1 / 8 \mathrm{in})$ of lead $(\mathrm{Pb})$.

The following paragraphs present a sketch of the data collection procedures used for this survey. Each of the experiments used a specific means of obtaining positioning information. The Kiwi used a differential global positioning system (GPS), licensed from John Chance Corporation, which has a positioning uncertainty of less than $1 \mathrm{~m}$ ( $3 \mathrm{ft}$ ). The HPGe Suburban has a slightly less accurate differential GPS system, which yields an uncertainty of 3-5 $\mathrm{m}$ (10-16 ft). Some of the locations measured by the Suburban in June were centered over locations marked by stakes in a circular grid which dates back to the $1960 \mathrm{~s}$. The $0^{\circ}$ reference of this circular grid appeared to be aligned with magnetic north, rather than the polar north implicit in the latitude, longitude coordinates of the GPS. The difference between polar north and magnetic north is about $15^{\circ}$ in the Double Tracks area. Most of the measurements made with the tripod detector systems and some of the Suburban measurements are referenced to this circular grid.

The coordinates listed in the literature for $G Z$ are

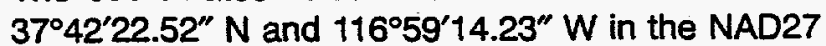
coordinate system. ${ }^{3}$ The GPSs used when collecting the data in this report are referenced to the WGS84 coordinate system. For the Double Tracks area, the U.S. Geological Survey (USGS) guidelines instruct one to move the NAD27 grid by $10 \mathrm{~m}$ (33 ft) $\left(0^{\circ} 0^{\prime} 0.32^{\prime \prime}\right)$ $\mathrm{N}$ and $79 \mathrm{~m}(259 \mathrm{ft})\left(0^{\circ} 0^{\prime} 3.23^{\prime \prime}\right) \mathrm{E}$ to convert the position into the WGS84 system. Applying this to the GZ position quoted above yields a position of $37^{\circ} 42^{\prime} 22.20^{\prime \prime} \mathrm{N}$ and $116^{\circ} 59^{\prime} 17.46^{\prime \prime} \mathrm{W}$ in the WGS84 system.

While no GPS measurements were made at GZ, Suburban-system measurements were made at the $30-\mathrm{m}$ (100-ft) positions on the circular grid at $0^{\circ}, 90^{\circ}, 180^{\circ}$, and $270^{\circ}$. These four measurements yield an average GZ position of $37^{\circ} 42^{\prime} 21.95^{\prime \prime} \mathrm{N}$ and $116^{\circ} 59^{\prime} 17.80^{\prime \prime} \mathrm{W}$ (in the WGS84 coordinate system). This average position is only $7.7 \mathrm{~m}(25.3 \mathrm{ft})\left(0^{\circ} 0^{\prime} 0.25^{\prime \prime}\right) \mathrm{S}$ and $8.4 \mathrm{~m}$ $(27.6 \mathrm{ft})\left(0^{\circ} 0^{\prime} 0.34^{\prime \prime}\right) \mathrm{W}$ of the published location.

The April survey made a number of isolated measurements and did not cover the whole Double Tracks area. In June, the Kiwi covered all of the area inside the fence as well as a few test spots south of the 

fence. The ATV covered most of the area inside the fence less than $152 \mathrm{~m}(500 \mathrm{ft})$ from $\mathrm{GZ}$.

\subsection{Experiment \#1 (April)-HPGe In Situ Measurements}

This experiment was designed to provide a correlation between the various methods of ground-based data taken during the April survey and, if possible, a comparison with the aerial data taken in December 1993. To this end, a series of measurements with the different instruments was taken in the same area. First, a four-wheel drive vehicle (Chevrolet Suburban, see Figure 1) with a collimated HPGe detector suspended on a mast $7.5 \mathrm{~m}$ ( $25 \mathrm{ft}$ ) above ground level (AGL) made a set of measurements across an area identified by the aerial data as having a relatively constant ${ }^{241} \mathrm{Am}$ concentration. The collimated detector views a circular area with a diameter of approximately $13 \mathrm{~m}$ ( $43 \mathrm{ft}$ ). In comparison, the aerial system made measurements with a $100-\mathrm{m}$ (330-ft) diameter spatial resolution.

At several of these locations, the mast was lowered and an additional measurement was made with the detector only $3 \mathrm{~m}(10 \mathrm{ft}) \mathrm{AGL}$. At this height, the fieldof-view for the ${ }^{241} \mathrm{Am} 60-\mathrm{keV}$ gamma rays is approxi-

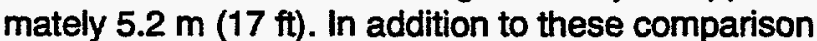
measurements, a number of isolated Suburban and tripod measurements were made throughout the fenced area.

\subsubsection{Suburban Versus Tripod Measurements}

Following the measurements taken by the Suburban system, a different HPGe detector, mounted on a tri-

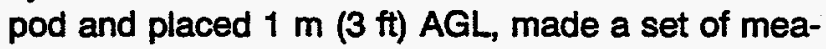
surements covering the area measured by the Suburban detector at a 3-m (10-ft) height. The tripod systems were collimated with a $\mathrm{Pb}$ shield to produce a field-of-view for the low-energy $241 \mathrm{Am} 60$-keV gamma rays of approximately $2 \mathrm{~m}$ (6.6ft). To minimize the number of measurements needed, the measurements were made using a triangular grid pattern. Thus the Suburban footprint could be almost covered by seven tripod measurements.

Following the tripod measurements, systems fielded by REECo and the Oak Ridge National Laboratory (ORNL) made their measurements in this same area.

\subsubsection{Measurements South of the Exclusion Fence}

A series of nine measurements was made south of the fenced area using a tripod-mounted HPGe detector. Measurements were made to corroborate the results obtained from the December 1993 aerial survey,

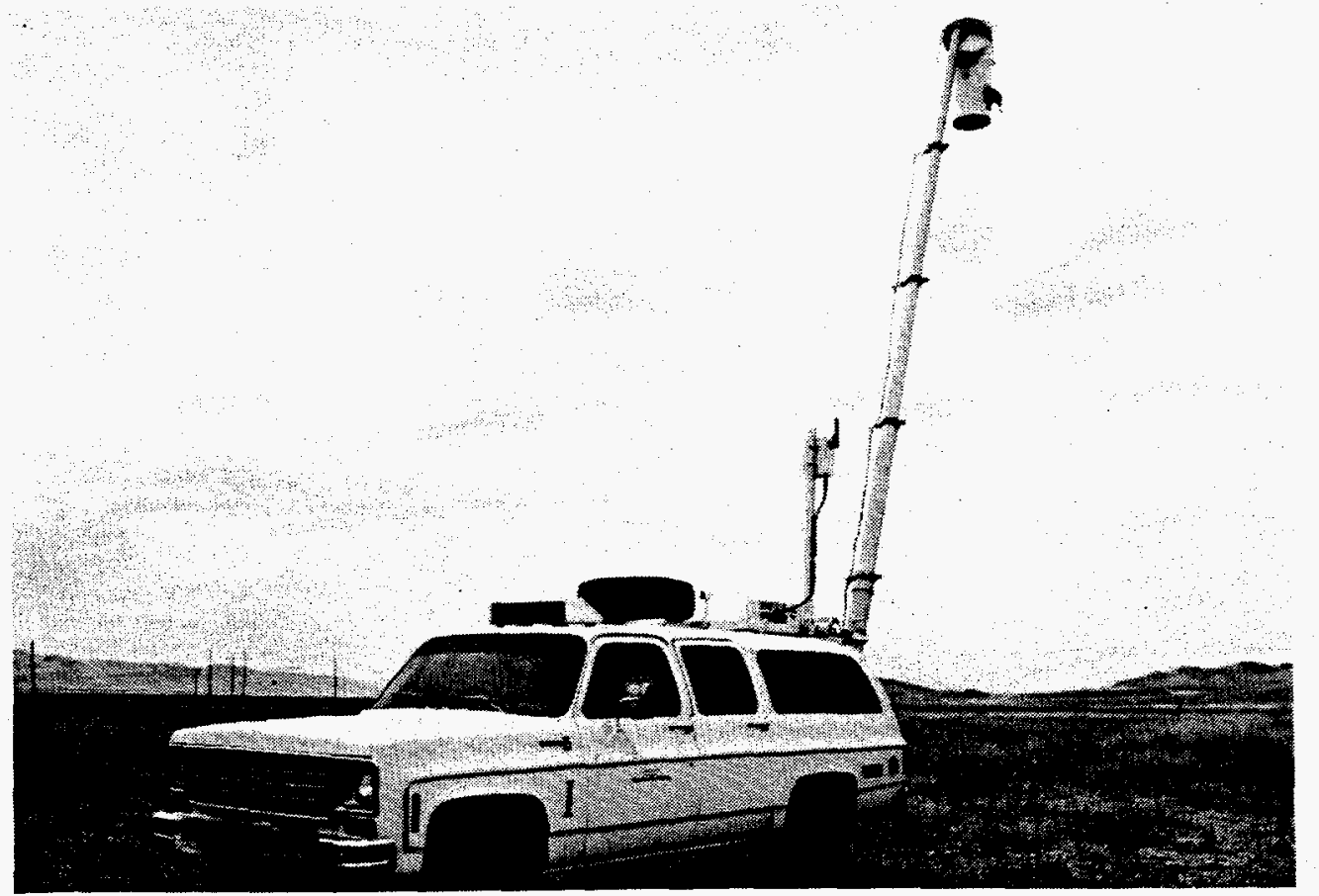

FIGURE 1. SUBURBANVEHICLEWTHHPGEDETECTORONMAST. The detectoron the end of the mast can be extended up to $7.5 \mathrm{~m}$ above the ground. 

which indicated a very low-level plume extending from the southern fence. Since there were no means to determine an exact position with this system, an attempt was made to pace off distances along the concentration center line of the plume using a compass for reference. The actual measurement line, however, deviated somewhat from the planned line.

\subsection{Experiment \#2 (April)_-Pu:Am Ratio Measurements}

The experiments performed at Double Tracks in April were intended to determine the nature and extent of TRU contamination by detecting gamma rays. All of the measurements rely on detecting the $60-\mathrm{keV}$ gamma rays emitted by ${ }^{241} \mathrm{Am}$, a daughter of ${ }^{241} \mathrm{Pu}$, and inferring the amount of $\mathrm{Pu}$ and TRUs through a combination of field measurements and theoretical considerations.

The activity levels in the eastern part of the central mound were high enough to allow direct measurement of the very weak gamma rays from ${ }^{239} \mathrm{Pu}$ at 129 $\mathrm{keV}, 375 \mathrm{keV}$, and $414 \mathrm{keV}$. The 129-keV gamma ray is approximately 6,000 times less intense per disintegration than the 60-keV gamma ray from Am. The other two Pu gamma rays are approximately 23,000 times less intense. The Pu:Am ratio is usually obtained in the laboratory using small soil samples that are chemically dissolved and then analyzed using alpha spectrometry. However, the physical characteristics of Pu make this laboratory analysis very difficult. Because the activities at the Double Tracks site are large enough, in situ measurements are capable of accurately measuring the gamma rays from $\mathrm{Pu}$. Thus the TRU:Am ratio calculated from the in situ data will have a better accuracy than the ratio from the laboratory analysis.

Two independent methods of measuring of the Pu:Am ratio were performed. The actual location on the mound was approximately $12 \mathrm{~m}(40 \mathrm{ft})$ from $\mathrm{GZ}$ and about $105^{\circ} \mathrm{E}$ of magnetic north (referenced to the circular grid). The first method used an HPGe detector mounted on a tripod $1 \mathrm{~m}(3 \mathrm{ft})$ AGL. The first set of measurements using this system left the detector uncollimated and the gamma-ray spectrum was written to tape at the end of 10-, 20-, and 30-minute periods. The second set of measurements used. a Pb collimator to reduce the field-of-view to about a 2-m (6-ft) radius. The plan in using the collimator was to collect the $60-\mathrm{keV}$ gamma rays from ${ }^{241} \mathrm{Am}$ and the $39-\mathrm{keV}$ and $51-\mathrm{keV} \mathrm{X}$-rays from ${ }^{239} \mathrm{Pu}$ from the same area.
The use of the collimator was not as successful as originally anticipated. The large Compton background generated by the ${ }^{241} \mathrm{Am}$ gamma rays made the extraction of the small quantity of $39-$ and $51-\mathrm{keV}$ gamma rays very difficult.

The second method to measure the Pu:Am ratio used a highly collimated, tripod-mounted HPGe detector. Measurements were made for 300 and 600 seconds. The measured gamma-ray count rates were then converted into the appropriate radioactivity values. To make this conversion for an in situ measurement, it is necessary to know or make assumptions on the depth distribution of the contaminant. Results are presented for assumed exponential distributions with relaxation lengths of 3,20 , and $100 \mathrm{~cm}(1,8$, and 40 in). The mound was formed by scraping the contaminated surface around the detonation site after the explosion, and this most likely led to contamination being mixed throughout the mound. In this case, a deeper depth distribution would be more representative of the contamination than the shallow distribution usually encountered due to weathering of surface Pu into the soil.

\subsection{Experiment \#3 (April)—Depth Profiling Measurements}

The purpose of these measurements was to develop an inexpensive, fast (hopefully field-calculable) method of measuring the ${ }^{241} \mathrm{Am}$ depth distribution over large areas of contamination. The depth distribution is required to convert $\mathrm{HPGe}$ in situ count-rate data into soil activity concentration results. It is also critical for obtaining a reasonable estimate of the amount of contaminated material that might have to be removed. Currently, the established method is to take soil samples from selected depths and analyze the samples in the laboratory. This method involves transportation of contaminated soil, time to prepare the samples, and the counting time in the laboratory. The final results are also sensitive to the depth interval used for each sample. Usually, samples are taken in $2.5-\mathrm{cm}(1-\mathrm{in})$ layers. This rather coarse sampling does not provide representative data for the shallow distributions typically encountered with $\mathrm{Pu}$ contamination. In typical Pu contamination situations, samples taken in 1- or $2-\mathrm{cm}$ layers are usually required. Hot pieces, routinely found around the safety shot tests, also introduce a serious problem in obtaining useful data.

Three techniques were evaluated during the April field survey for obtaining depth profile data. These include the following: 
- Side wall measurements with TLD material

- Comparison between the X-rays from ${ }^{239} \mathrm{Pu}$ and the gamma ray from ${ }^{241} \mathrm{Am}$

- Direct measurement with highly collimated HPGe detector as thin layers of soil were removed

\subsubsection{Side Wall Measurements with Thermoluminescent Dosimetry Material}

Thermoluminescent material, when used for thermoluminescent dosimetry (TLD), can be used to measure surface alpha contamination. The TLD material used for these measurements $\left(\mathrm{CaSO}_{4}: \mathrm{Tm}\right)$ is gamma insensitive, with a beta sensitivity approximately 100 times less than the alpha sensitivity. The alpha sensitivity is quite high with about one Read-Out Count (ROC) per disintegration per minute (dpm) and a large dynamic range in which the sensitivity is linear. This allows their use in mapping areas containing low to very high levels of radioactivity. Measurements made previously with this material in Area 11 of the Nevada Test Site (see Appendix B) accurately portrayed the erratic surface distribution of the TRU isotopes around those safety shot sites. It was found that a good deal of the contamination is in discrete "hot spots" that can cause rapid variations in activity levels over distances of only a few centimeters. This is why typical soil sample counting can produce widely varying results even for samples taken adjacent to each other. Because the material proved so successful for the surface measurements, an attempt was made to try to obtain similar results for depth profiles.

The TLD material was affixed to sheets $30 \mathrm{~cm}$ (12 in) on each side. Readout can be controlled to $1-\mathrm{mm}$ (0.04-in) intervals in both the $x$ and $y$ directions, providing excellent spatial resolution for the measurements. Thirty-minute measurements are sufficient to obtain background alpha activity levels. The material was then sent to a laboratory for analysis. If these measurements are performed routinely, a film reading station could be purchased for field use. The film is reusable after it has been analyzed and read.

Six TLD sheets were used, in pairs, at three measurement locations. One sheet was placed on the surface. The other sheet was inserted into the ground by digging a small trench, placing the sheet against the wall, and then backfilling the trench to hold the sheet in place for the required exposure time. This created a "surface" approximately $25-30 \mathrm{~cm}(10-12$ in) deep and $30 \mathrm{~cm}$ (12 in) across. The TLD sheet was held against the side wall for approximately 30 minutes. All three measurements were made near the inner fence south of $\mathrm{GZ}$.

\subsubsection{Comparison Between the Pu X-Rays and the 241 Am Gamma Ray}

A second technique evaluated during the April expedition tried to measure the difference in the number of $60-\mathrm{keV}^{241} \mathrm{Am}$ gamma rays compared to the number of 17- to 23-keV X-rays emitted during the decay of ${ }^{241} \mathrm{Am}$ and the various $\mathrm{Pu}$ isotopes.

$\mathrm{Pu}$ contamination is usually measured using the 60-keV gamma ray from ${ }^{241} \mathrm{Am}$. It can also be detected using the $L X$-rays from the $\mathrm{Pu}$ and $\mathrm{Am}$ decay in the 17- to 23-keV range. For contamination near the surface, the $X$-ray region is useful. Due to the rapid attenuation of these low-energy $X$-rays in soil, however, the $60-\mathrm{keV}$ gamma ray is more useful for activity that has migrated into the soil. The mass attenuation coefficient for soil at $20 \mathrm{keV}$ is approximately ten times greater than at $60 \mathrm{keV}$. The X-rays will be attenuated much faster with depth in soil than the 60-keV gamma ray. This difference in attenuation may be able to provide an indicator of the contamination distribution with depth. To make the measurements, it is necessary to ensure that all radiation reaching the detector travels through the same depth of soil. This can be done using a long collimator that only allows radiation from directly below the detector to be counted. The ratio of the $60-\mathrm{keV}$ gamma ray to one or more of the $X$-rays would then provide an indicator of the depth of the contamination.

With an HPGe detector mounted on a low tripod, a collimator was built that extended from the detector to the ground to ensure only radiation from directly below the detector would be counted. The collimator was made of tin (Sn) with an inner liner of copper (Cu). Since the collimator (as well as the detector) will be bathed by the gamma rays from the natural radionuclides, a fraction of the atoms will be excited by the gamma rays and will emit their own particular-energy $X$-rays. Thus, since the collimator material is going to emit $X$-rays which will be detected, the goal is to find a collimator material which adds the fewest counts to the particular-energy range of interest. Sn is somewhat better than $\mathrm{Pb}$ for these applications. $\mathrm{Pb}$ has $\mathrm{KX}$-rays in the $70-90 \mathrm{keV}$ range which increases the background in the 60-keV window. $\mathrm{Pb}$ also has $\mathrm{L} X$-rays which extend into the $P u$ and $A m X$-ray window. Sn has $K$ $X$-rays just above the Pu-Am window and $L X$-rays below this window. The $\mathrm{Cu}$ liner stops the $\mathrm{KX}$-rays 
and puts all possible interference from the collimator below the Pu-Am X-ray window.

Six measurements were made just inside and outside the inner fence. Measurements were made at the three locations where the TLD material measurements were conducted and at three additional areas where spot FIDLER measurements showed elevated activity.

\subsubsection{Direct HPGe Measurements}

The third technique that was evaluated directly measured the ${ }^{241} \mathrm{Am}$ activity level as thin layers of soil were removed. A detector was collimated to limit the field-of-view to an area approximately $40 \mathrm{~cm}$ (16 in) in diameter. Soil was then removed in layers approximately $1-3 \mathrm{~cm}(0.4-1.2 \mathrm{in})$ thick, with measurements made after each layer was removed. Spraying the soil lightly and uniformly with a little water allowed a person with a metal dustpan to scoop up a thin layer of soil and minimize the creation of blowing dust. A little practice was required to avoid getting the ground too wet too deep and to scoop up only a thin layer of soil. The soil was removed over an area larger than the field-of-view of the collimated detector to ensure that only the newly exposed surface was measured.

This method is similar to obtaining profile samples in the field and returning them to a laboratory for analysis. The primary differences are the much larger sample size counted (approximately $1,600 \mathrm{~cm}^{2}$ [248 in $\left.{ }^{2}\right]$ verses $100 \mathrm{~cm}^{2}$ [16 in $\mathrm{in}^{2}$ for a typical soil sample) and the convenience of not having to transport soil from the site.

\subsection{Experiment \#4 (June)-ATV Hot-Piece Search}

FIDLER detectors have been used extensively in the past for locating regions contaminated with ${ }^{241} \mathrm{Am}$ (and $\mathrm{Pu}$ by inference). Although the system only reports the total count rate observed in the detector, medium-or high-energy gamma rays are very unlikely to have any interaction with the very thin detector crystal. This makes the detectors insensitive to much of the variation in the natural terrestrial radioactive isotopes or to fallout isotopes such as ${ }^{137} \mathrm{Cs}$.

During the April expedition, a hand-held FIDLER found many locations where the radioactivity level was elevated and very localized. In most of these cases, small pieces of metal with Pu and Am adhering to the surface were found in the area. Two locations were "mined" by IT personnel. "Before" and "after" measurements of these locations produced encouraging results (see Section 6.1). During the week of the April expedition, it became very clear that there were many localized regions near $G Z$ with elevated activities.

The ATV experiment was included in the June expedition to test our ability to systematically locate and remove the fragmented pieces. A set of three collimated FIDLER detectors mounted on the ATV is shown in Figure 2. This system traveled east and west inside the fenced area within several hundred feet of $G Z$ to look for hot pieces. The collimators on the detectors limited the fields-of-view to about a $0.6-\mathrm{m}$ (2-ft) diameter on the ground. There was sufficient overlap between the fields-of-view to ensure that complete coverage was obtained over an area about $1.5 \mathrm{~m}(5 \mathrm{ft})$ wide.

Because this was still an experimental vehicle, the driver had to steer the ATV by keeping the tire tracks from the previous pass a constant distance to the side. While the ATV occasionally had to be maneuvered around some of the larger bushes, the amount of ground possibly missed by the detectors was very small. If the detected activity exceeded a set level, an alarm sounded. A larger than expected amount of time was spent at Double Tracks determining the optimum trip levels for the alarms on the detectors. It was finally determined that $50 \%$ above background was a reasonable level which resulted in finding many hot pieces and produced very few faise alarms. (False alarms were often produced if the ATV bounced excessively while going over a bush or the edge of a small wash.)

When the alarm on one or more detectors sounded, the driver would stop and back over the area to verify that it was not a false alarm and then place a colored flag in the ground. A group of "miners" would go to each of the flagged locations with a hand-held FIDLER and shovels to find the hot piece and remove it from the area. Fragments were usually located immediately using the hand-held FIDLER, but after a while, the miners sometimes could recognize fragments visually before using the FIDLER. After removing the fragment, the FIDLER would be used to survey the immediate area for any flakes which may be left behind from the original fragment. In a few instances, the radiation was spread over a small area and a few shovels of soil and hot particles were excavated. The hot fragments and soil containing hot particles were 



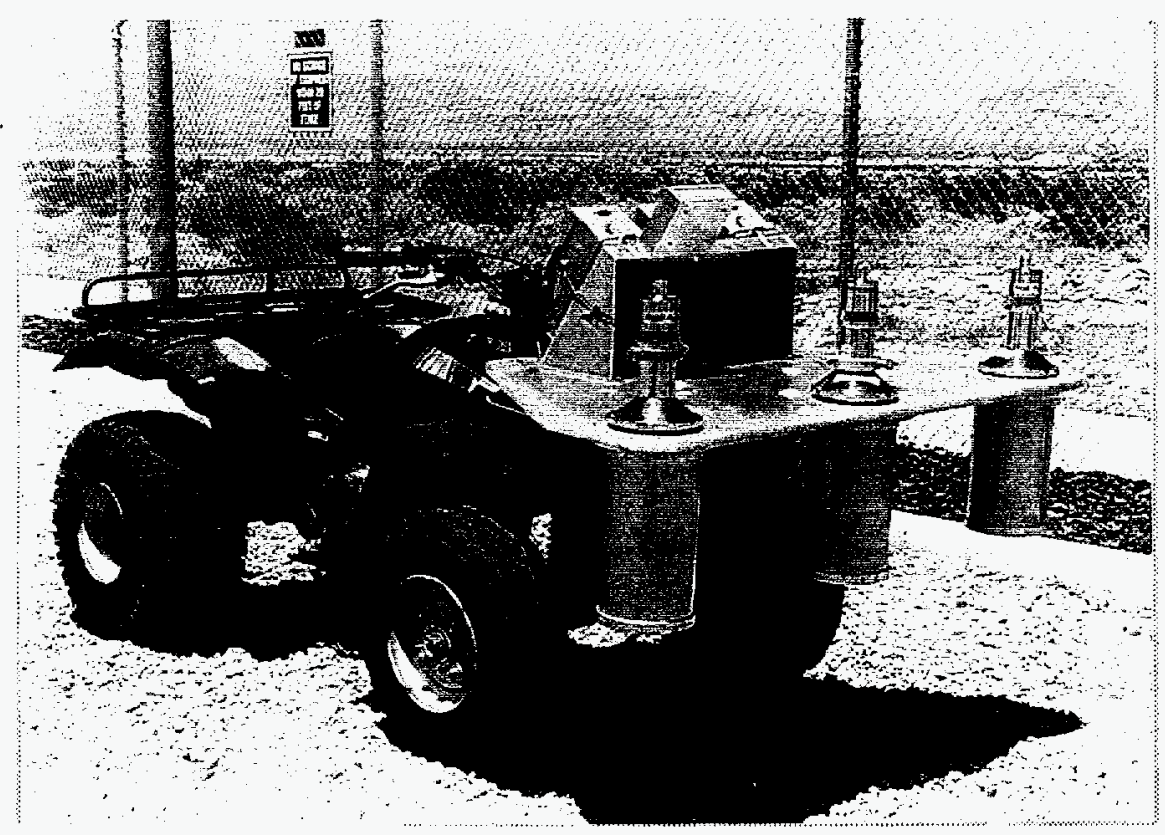

FIGURE 2. ATV WITH FIDLERDETECTORS. The three detectors see slightly overlapping areas on the ground as the ATV travels at several feet per second. A sharp rise in the count rate by one of the detectors signifies a hot piece underneath that detector.

placed in secured containers for later disposal during the clean-up operations.

\subsection{Experiment \#5 (June)-Riwi Survey Measurements}

The Kiwi system is the result of mounting the detectors and data collecting system from RSL's standard aerial system onto a Chevrolet Suburban vehicle (see Figure 3). Six 5- $\times 10-\times 40-\mathrm{cm}(2-\times 4-\times 16$-in $)$ Nal logs are housed in pods mounted on an angle-iron frame attached in place of the rear bumper. Signals from these detectors feed into a Radiation and Environmental Data Acquisition and Recorder (REDAR), Model IV, system bolted to the floor of the Suburban. Signals from the GPS constellation of satelites, received by the antenna mounted above the detectors, are preprocessed by a John Chance Corporation unit before feeding into the REDAR system. The second antenna, mounted on the roof of the Suburban, receives a correction signal from a network of GPS stations around the country. The signal is relayed through a dedicated satellite for John Chance Corporation subscribers. This correction signal reduces the uncertainty in positioning the vehicle to less than $1 \mathrm{~m}(3 \mathrm{ft})$ rather than the 3-5 $\mathrm{m}$ (10-15 ft) uncertainty in the earlier correction hardware employed in the helicopter system.
The Kiwi detectors are shielded on the back and sides with a sheet of cadmium (Cd) while the end-mounted photomultiplier tubes and the vehicle itself provide shielding to the front of the detectors. This shielding is more than adequate for attenuating the $60-\mathrm{keV}$ gamma rays of ${ }^{241} \mathrm{Am}$ but does not significantly affect the higher energy radiation from the natural radioisotopes. The shielding produces a well-defined footprint for making assessments of the Am concentration in a given volume of soil. Thus the ${ }^{24 !} \mathrm{Am}$ footprint of the stationary Kiwi system is about $3 \mathrm{~m}(10 \mathrm{ft})$ in width and $1.2 \mathrm{~m}(4 \mathrm{ft})$ long. With the Kiwi traveling at $2.2 \mathrm{~m} / \mathrm{s}(5$ $\mathrm{mph} ; 7 \mathrm{ft} / \mathrm{s}$ ), the footprint is about $3 \mathrm{~m}(10 \mathrm{ft})$ wide by $3.4 \mathrm{~m}(11 \mathrm{ft})$ long.

Just like the aerial platforms, the REDAR system in the Kiwi was programmed with a set of "flight" lines to travel during the survey. For simplicity and to minimize the amount of time needed to turn around inside the fence, the lines were arranged parallel to the western fence making them almost due north-south. The GPS position was compared to this preferred flight path each second, and the deviation (left or right) from the line was displayed for the driver on a meter mounted above the dashboard. The flight lines were only $3 \mathrm{~m}$ $(10 \mathrm{ft})$ apart. With the rough terrain in several spots, some deviation from the planned flight lines was necessary. 



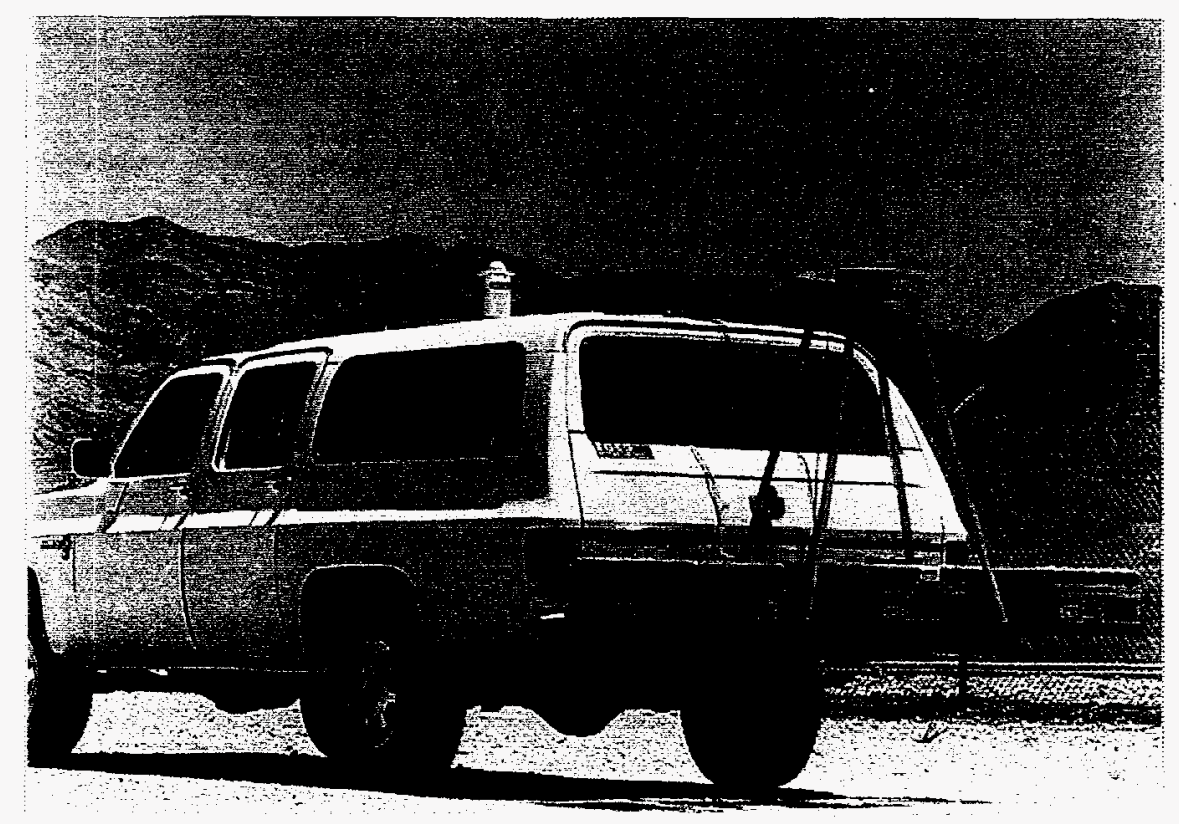

FIGURE 3. KIWIVEHICLE. SixNallogs in the three pods on the rear of the Suburban vehicle detect gamma rays from $A m$. Shielding on the sides of the detectors limits the field-of-view to less than $1 \mathrm{~m}$ on either side of the pods. The two GPS antennas collect normal GPS signals from the satellite constellation and correction signals from the John Chance network.

For the June expedition, the barbed wire on the inner rence was removed, but the fence posts were left in the ground. The Kiwi had to occasionally be driven around rough terrain and various posts in the exclusion area. The removal of the barbed wire inner fence permitted the Kiwi to get inside the fence and gather data close to the mound. However, the terrain of the GZ mound and the depression just northeast of the mound was considered too steep and the Kiwi was not driven over that area. The mound was assumed to be an area which would have to be excavated and removed regardless of the measured level of activity, so no concerted attempt was made to collect data over the mound. This produced a "hole" in the data which needed to be addressed in the data analysis. The extensive general data analysis procedures for the Kiwi data are described later in Section 5. The specific handling of the "hole" is described in Section 6.5.

\subsection{Experiment \#6 (June)-HPGe in Situs Measurements}

This experiment was a check and verification of the Kiwi system during the June expedition. The Suburban system, described in Experiment \#1, made more than 50 measurements of the ${ }^{241} \mathrm{Am}$ activity at various locations both inside the exclusion fence and around the periphery. In addition, two measurements were made in the plume which extends south of the exclusion area and one measurement was made at the revegetation site northeast of Double Tracks.

The majority of the 50 measurements were conducted to transect the site from south to north and from west to east passing through the $G Z$ area. Since some additional time remained after these measurements were made, several additional measurements were conducted along the circular grid axes at $120^{\circ}, 150^{\circ}$, $210^{\circ}$, and $240^{\circ}$ to define the plume better in these directions.

\subsection{Experiment \#7 (June)-Hot-Piece Activity Measurements}

This experiment was intended to measure the total ${ }^{241} \mathrm{Am}$ activity on several of the chunks of material found by either the ATV system or by technicians using hand-held FIDLERs or spotting them visually while walking around. This debris appeared to be metallic pieces from the explosion with some surface $\mathrm{Pu}$ contamination. Several of these pieces were weighed, photographed, and measured for activity 

level using an HPGe detector. Both sides of each piece were measured and an effective activity value determined.

In addition to the metallic debris, soil samples collected from the hottest areas within the inner fence were also measured. The soil was placed inside plastic bottles approximately $5 \mathrm{~cm}$ (2 in) in diameter and $15 \mathrm{~cm}$ ( $6 \mathrm{in}$ ) tall. Measurements were made from each side of the bottle and an effective activity value determined.

\subsection{DATA REDUCTION PROCEDURES}

Several methods for processing the Kiwi data may be employed. The gross count rate method calculates the total counts from all gamma rays detected during each one-second sample and presents the results as a series of equal count-rate contours superimposed on a map or photograph of the survey area. With this display, large-scale variations of the radiation field within the whole survey area may be easily seen. Since the size of the Double Tracks survey area is relatively small and there are no real variations in the geology of the area, the gross count plot is quite flatexcept in areas containing Pu contamination.

Variations in the total radiation field are not always of interest. At Double Tracks, the major contaminant is $\mathrm{Pu}$ (and its gamma-ray-emitting daughter $\mathrm{Am}$ ). With this knowledge, the count rate in the ${ }^{241} \mathrm{Am}$ photopeak can be plotted versus position and a more sensitive plot of the contamination can be made from the isotopic count rate.

The main data reduction interest for this survey was the isotopic stripping of the ${ }^{241} \mathrm{Am}$ photopeak. The gross count rate method was principally a check to ensure that the data from adjacent "flights" matched each other and to provide a picture of the overall radiation field in the survey area.

\subsection{Gross Count Rate Algorithm}

The gross count rate is the sum of the counts in the energy range from $38 \mathrm{keV}$ to $3,026 \mathrm{keV}$, divided by the live time, and subtracting a background term which represents all nonterrestrial sources.

$$
c_{G}=\left(\frac{1}{t_{\text {Live }}} \sum_{E=38}^{3026} c(E)\right)-C_{N}
$$

where

$$
\begin{aligned}
C_{G}= & \text { gross count rate at the height of the detector } \\
& \text { (counts/s) } \\
t_{\text {Live }}= & \text { live time during collection of gamma-ray } \\
& \text { spectrum (s) } \\
c(E)= & \text { the counts in the energy spectrum at the } \\
& \text { energy } E \text { (counts) } \\
C_{N}= & \text { the count rate attributable to nonterrestrial } \\
& \text { sources (counts/s) }
\end{aligned}
$$

The lower energy limit is an effective lowest energy which the detector system can reliably record. Although the detector system processes and records all detected gamma rays up to $4,000 \mathrm{keV}$, there are almost no gamma rays of interest with energies above $3,000 \mathrm{keV}$, and the higher energies are generally ignored. The total number of counts attributable to nonterrestrial sources includes gamma rays emitted by airborne Rn and its daughters, cosmic rays, and vehicle and equipment contributions.

\subsection{Isotope Extraction Algorithms}

Before describing these windowing techniques, a few points need to be made about the energy spectrum. in general, the gamma rays emitted by naturally occurring radioisotopes have very precise, well-defined energies. If the gamma rays could be measured ideally, the energy spectrum would consist of very tall, very narrow photopeaks centered at the total energy of the gamma ray. (Some of the peaks would be riding on top of the slowly varying distribution of Comptonscattered gamma rays from other isotopes, but the peaks would be narrow.) However, the detector and associated electronics used to measure the gamma rays have energy resolutions which broaden the photopeak distribution. The spectrum actually recorded by the measuring system will have broader, Gaussian-shaped peaks with widths equal to the resolution of the detection system.

The total number of counts contained in the Gaussian-shaped photopeak can be obtained by summing all of the counts within a specific energy range, $\Delta E$, of the gamma-ray energy, $E$. The magnitude of $\Delta E$ will determine the fraction of the total counts which are summed. If $\Delta E=3 \sigma$, where $\sigma$ is the standard deviation of the Gaussian distribution, then $99.7 \%$ of the total photopeak counts will be included in the sum. This is not an unreasonable assumption for HPGe detectors, which have very narrow peak shapes. However, if the standard deviation for the system is large, as is the 
case for $\mathrm{Nal}$ detectors, then the distributions from different photopeaks can overlap significantly. This interference between peaks can be minimized by decreasing $\Delta E$, with the knowledge that not all of the counts will be included in the sum. A correction factor, determined in a region free of conflicting peaks, can be found to relate the number of counts in the range $E \pm \Delta E$ to the total counts in the peak.

\subsubsection{Two-Window Algorithm}

The two-window algorithm is the simplest of several window algorithms in use. It employs a narrow window centered on the energy of the specific photopeak. A background window, located at higher energies, assumes that the background counts in the photopeak window are proportional to the total counts recorded in the background window. The background window may abut the photopeak window or may be separated from it in energy. The equation for the twowindow algorithm follows:

$$
C_{2-\text { Window }}=\sum_{E=E_{1}}^{E_{2}} c(E)-K_{2} \sum_{E=E_{3}}^{E_{4}} c(E)
$$

with

$$
K_{2}=\frac{\sum_{E=E_{1}}^{E_{2}} c_{b k g}(E)}{\sum_{E=E_{3}}^{E_{4}} c_{b k g}(E)}
$$

where

$$
\begin{aligned}
C_{2-W i n d o w}= & \text { the net counts in the photopeak from the } \\
& \text { two-window algorithm } \\
c(E)= & \text { the counts in the gamma-ray energy } \\
& \text { spectrum at the energy } E \\
E_{n}= & \text { the limiting energies of the windows } \\
& \left(E_{1}<E_{2} \leq E_{3}<E_{4}\right) \\
K_{2}= & \text { the ratio of the counts in the photopeak } \\
& \text { window to the counts in the background } \\
& \text { window in a clean region of the survey } \\
& \text { area }
\end{aligned}
$$

$$
\begin{aligned}
c_{b k g}(E)= & \text { the counts in the gamma-ray energy } \\
& \text { spectrum at the energy } E \text { in a clean } \\
& \text { region of the survey area }
\end{aligned}
$$

The proportionality factor, $K_{2}$, is determined in a region of the survey which does not contain any of the specific isotope, so that the photopeak window contains only its background counts and therefore is directly related to the number of counts in the background window. If the principle source of background gamma rays in the photopeak window is from scattered gamma rays from photopeaks at higher energies, this is a reasonable assumption. If there are isotopes other than the one of interest with photopeaks in the photopeak window, this algorithm will likely fail.

\subsubsection{Three-Window Algorithm}

If a region free of the specific isotope cannot be found or if the composition of the other isotopes changes drastically between the clean region and the rest of the survey area, then a simple multiplicative factor will not relate the counts in the photopeak window to the counts in the background window. To solve this problem, the three-window algorithm employs a background window on each side of the photopeak window. (In this case, the two background windows abut the photopeak window in energy.) This algorithm assumes that, for any spectrum, the number of background counts in the photopeak window is linearly related to the counts in the two background windows. The equation for the three-window algorithm follows:

$$
C_{3-\text { Window }}=\sum_{E=E_{2}}^{E_{3}} c(E)-K_{3}\left[\sum_{E=E_{1}}^{E_{2}} c(E)+\sum_{E=E_{3}}^{E_{4}} c(E)\right]
$$

with

$$
K_{3}=\frac{\sum_{E=E_{2}}^{E_{3}} c_{b k g}(E)}{\sum_{E=E_{1}}^{E_{2}} c_{b k g}(E)+\sum_{E=E_{3}}^{E_{4}} c_{b k g}(E)}
$$

where

$$
\begin{aligned}
C_{3-W i n d o w}= & \text { the net counts in the photopeak from the } \\
& \text { three-window algorithm }
\end{aligned}
$$




$$
\begin{aligned}
& E_{n}= \text { the limiting energies of the windows } \\
&\left(E_{1}<E_{2}<E_{3}<E_{4}\right) \\
& K_{3}= \text { the ratio of the counts in the photopeak } \\
& \text { window to the counts in the two back- } \\
& \text { ground windows in a clean region of the } \\
& \text { survey area }
\end{aligned}
$$

The three-window algorithm is also very useful in extracting low-energy photopeak counts where the shape of the Compton-scatter contributions from other isotopes is changing significantly.

Both the two- and three-window algorithms were applied to the Double Tracks data. In this particular case, the three-window algorithm produced an output which was more stable with regard to statistical variations in the data set.

\subsection{Gridding of Data}

To produce most of the plots in this report, the Kiwi data were forced into a 9-m (30-ft) grid. Since the data were collected second-by-second, the speed of the vehicle was not constant, and the actual "flight" lines often covered the same ground, gridding was necessary for the later processing. Since the interest in the data is predominantly to determine the ${ }^{241} \mathrm{Am}$ activity over square areas of $10-\mathrm{m}(33 \mathrm{ft})$ and $100-\mathrm{m}(330-\mathrm{ft})$ size, the gridding does not significantly degrade the spatial resolution of the data.

Once the grid is constructed, all spectra whose positions lie inside a grid cell are summed and an average count rate is calculated for the center of the grid.

$$
c_{g}\left(E, x_{c}, y_{c}\right)=\frac{1}{N} \sum_{i=1}^{N} c\left(E, x_{i}, y_{i}\right)
$$

where

$$
\begin{aligned}
c_{g}\left(E, x_{c}, y_{c}\right)= & \text { the average number of counts in the } \\
& \text { gamma-ray spectrum at energy } E \text { at } \\
& \text { the center of the grid cell at location } \\
& \left(x_{c}, y_{c}\right) \\
N= & \text { the number of data samples } \\
& \text { contained within the grid cell } \\
c\left(E, x_{i}, y_{i}\right)= & \text { the number of counts in the gamma- } \\
& \text { ray spectrum at energy } E \text { from the } i \text { th } \\
& \text { spectrum collected at location }\left(x_{i}, y_{i}\right)
\end{aligned}
$$

The uncertainty in the gridded data $\left(\sigma_{g}\right)$ is roughly $1 / \sqrt{N}$ of the uncertainty of one of the original measurements $(\sigma)$.

\subsection{Count Rate Conversion to Soil Activity Concentration}

The conversion from the count rate measured by a detector system to the activity of the isotope in the soil depends on several factors involving the radiation source, the intervening material, and the detection system. These factors include (a) ground roughness, (b) the distribution of the isotope in or on the soil, (c) the energy of the gamma ray emitted by the isotope, (d) the air density, (e) the amount of moisture in the soil, (f) the sensitivity of the detector system to the incident radiation, (g) the geometry of the detectorsource arrangement including the use of collimators, and $(h)$ the amount of background radiation (principally cosmic rays, vehicle and equipment background, and airborne $\mathrm{Rn}$ ) present.

The soil activity concentrations deduced from the Kiwi system count rate are based on a simple multiplicative factor. The Kiwi was parked over an area inside the fence, and the count rate was measured for several minutes. This was an area which produced a fairly high count rate on both the Suburban system and on a hand-held FIDLER detector. The activity in this same area was also recorded in a series of HPGe tripod system measurements. To within the accuracy in which the two systems could measure the activity of the same location, this technique ensures consistency between the activities measured by the Kiwi and tripod systems. The conversion from count rate to activity for the tripod systems has been used extensively in the past and is briefly outlined below. The major problem with the area used at Double Tracks was the nonuniformity of the activity distribution. As seen throughout the survey area, the Am was dispersed in clumps in the high activity areas. There were large variations (a factor of 2-3) between the five tripod measurements, indicating that the activity was concentrated in one or two areas.

\subsubsection{Distribution of the Isotope in the Soil}

Three basic types of vertical distributions are commonly observed in the course of radiological surveys. All of the models used in this work assume that extended sources are uniform in the horizontal directions. That is, the only variation in the concentration 
of the isotope in the soil is with depth. The uniform distribution in the horizontal plane leads to results expressed in terms of an average value over the fieldof-view of the detector.

The naturally occurring radioisotopes are distributed uniformly as a function of depth. The fallout from the aboveground nuclear tests in the 1950s and 1960s began as a surface distribution. That is, all of the radioactivity lies in a thin layer of material on the ground. After a number of years, as the radioactive material has a chance to migrate into the soil, the initial surface distribution evolves into an extended distribution which is usually modeled by an exponential function. The relaxation length for the exponential distribution is expressed as $1 / \alpha$. For the Pu and Am dispersed over 30 years ago at Double Tracks, an exponential distribution is assumed.

$$
S(z)=S_{E 0} e^{-\alpha z}
$$

where

$$
\begin{aligned}
& S(z)= \text { the activity concentration of the isotope at } \\
& \text { the depth } z \\
& S_{E O}= \text { the activity concentration of the isotope at } \\
& \text { the surface of the soil } \\
& a= \\
& \text { the inverse of the exponential relaxation } \\
& \text { distance }
\end{aligned}
$$

For the exponential distribution, the volume of soil from the surface down to a depth of $1 / \alpha$ contains approximately $63 \%$ of the isotope's total activity. At depths of $2 / \alpha$ and $3 / \alpha$ the volume of soil contains approximately $86 \%$ and $95 \%$ of the total activity, respectively. (This is different from the percent of the isotope which can be measured from a detector above the ground. If the gamma-ray energy is small, then regardless of the vertical distribution of the isotope, only the gamma rays emitted from the nuclei near the surface will be able to reach the detector with their full energy.)

\subsubsection{Derivation of the Conversion Factors}

The conversion factors are determined by combining a laboratory measurement of the detector's efficiency to a given gamma-ray energy with a theoretical calculation of the gamma-ray flux arriving at the detector as a function of source distribution in the soil. The derivation of these equations is given in several previous reports (for example Reference 8) which are generally based on the assumptions and derivations in the work by Beck. ${ }^{9}$

The number of photopeak counts registered by the detector depends on the flux of gamma rays at the location of the detector and a quantity, which is designated as the effective detector area, $A$. Since the probability of a gamma ray depositing its full energy in the detector depends on the detector dimensions, orientation, and gamma-ray energy, the effective area is not easily calculable. Instead the effective area is measured in the laboratory and expressed as a zerodegree value, $A_{0}$, multiplied by a function, $R(\theta)$, which contains all of the angular response. The effective area is measured at $10^{\circ}$ intervals and linear interpolation is applied between the measured values.

The measured photopeak count rate can be expressed as an integral over the factors for the source activity in the soil, the detector's effective area, the distance from source to detector, and the attenuation of the gamma rays by the intervening material (air and soil). Figure 4 presents a visual representation of the detector-source geometry.

$$
\begin{aligned}
C_{p}= & \int_{0}^{\infty} \int_{0}^{\infty} \frac{S(z) A_{0} R(\theta)}{4 \pi d^{2}} \\
& e^{-\left(\frac{\mu}{\rho}\right)_{a} \rho_{a} d_{a}} e^{-\left(\frac{\mu}{\rho}\right)_{s} \rho_{s} d_{s}} 2 \pi r d r d z
\end{aligned}
$$

where

$$
\begin{aligned}
C_{p}= & \text { the net photopeak count rate } \\
S(z)= & \text { activity per unit volume }\left[(\gamma / \mathrm{s}) / \mathrm{cm}^{3}\right] \\
A_{0}= & \text { the effective area of the detector at } 0^{\circ} \\
R(\theta)= & \text { the angular response of the detector at the } \\
& \text { angle } \theta \\
d= & d_{a}+d_{s}, \text { the distance from the source } \\
& \text { element to the detector }(\mathrm{cm}) \\
(\mu / \rho)_{a, s}= & \text { air or soil mass attenuation coefficient } \\
& \left(\mathrm{cm}^{2} / \mathrm{g}\right) \\
\rho_{a, s}= & \text { air or soil density }\left(\mathrm{g} / \mathrm{cm}^{3}\right)
\end{aligned}
$$

Before proceeding any further with the derivation, the isotopic distribution in the soil must be determined. If no soil samples are available to determine the distribution, a distribution is assumed. Knowledge of the particular isotope and some history of how it might have arrived at this location as discussed in Section 5.4.1 will determine the form of $S(z)$. For the remainder of this derivation, the exponential distribution (see Equation 8) will be assumed. 


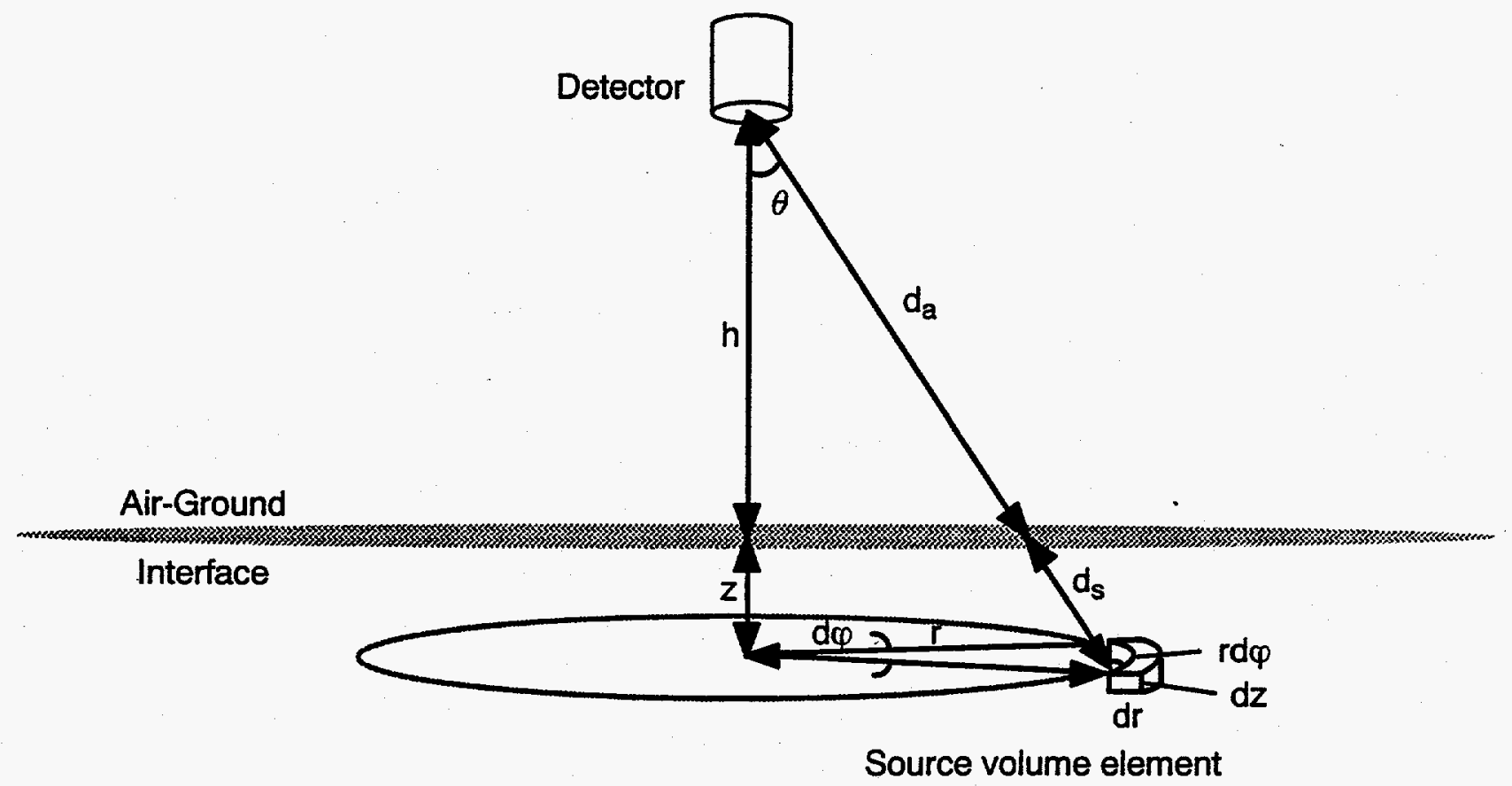

FIGURE 4. GEOMETRY FOR RADIATION MEASUREMENTS. The detector-soil element geometry applies to both aerial and in situ measurements. The count rate of the detector results from the integrated gamma ray flux from all of the individual source elements.

Following a change in the integration variables and for the exponential depth distribution, the count rate equation becomes

$C_{p}=\frac{S_{E 0} A_{0}}{2} \int_{0}^{\pi / 2} \frac{R(\theta) \tan (\theta) e^{-\left(\frac{\mu}{\rho}\right)_{a} \rho_{a} h \sec (\theta)}}{a+\left(\frac{\mu}{\rho}\right)_{s} \rho_{s} \sec (\theta)} d \theta$

\subsubsection{Conversion Factors for Selected Isotopes in the Soil}

The expression in Equation 10 relates the measured photopeak count rate, $C_{p}$, to the activity per unit volume at the surface, $S_{E O}$. The detector parameters, $A_{0}$ and $R(\theta)$, are usually obtained empirically for a given system using standard calibration sources. Mass attenuation coefficients for air and typical soils can be found in standard reference tables. An average soil density of $1.5 \mathrm{~g} / \mathrm{cm}^{3}$ is usually assumed unless actual measured values are available. The air density is calculated from measurements of the temperature and barometric pressure. The detector height, $h$, is measured and the inverse of the exponential relaxation length, $a$, is either measured or assumed. It is then a simple case of calculating the required integral numerically to obtain the conversion factor, $F_{E}$.

$$
\frac{1}{F_{E}}=\frac{C_{p}}{S_{E 0}}=\frac{A_{0}}{2} \int_{0}^{\pi / 2} \frac{R(\theta) \tan (\theta) e^{-\left(\frac{\mu}{\rho}\right)_{a} \rho_{a} h \sec (\theta)}}{a+\left(\frac{\mu}{\rho}\right) \rho_{s} \rho_{s} \sec (\theta)} d \theta
$$

The conversion factor relates a measured photopeak net count rate, expressed in units of counts per second, to source activity at the surface expressed in units of gamma rays per second per unit volume. For a specific isotope, the source activity is generally changed to units of curies or becquerels. The average activity per unit volume can also be converted to average activity per unit mass by dividing by the soil density.

\subsubsection{Average and Total Activity}

When the interest is comparing the activity measured in situ with the activity obtained from a series of soil sample measurements, it is more useful to relate the photopeak net count rate data to an average concentration within a given soil depth rather than as the 
exponential concentration at the surface. For a source distributed exponentially with depth, the average concentration in the top $z_{s}$ is calculated with the following equation:

$$
<S_{z_{s}}>=\frac{1}{z_{s}} \int_{0}^{z_{S}} S_{E 0} e^{-a z} d z=\frac{S_{E O}}{a z_{s}}\left(1-e^{-a z_{s}}\right)
$$

Soil samples generally collect all of the soil to a specific depth. The soil is taken to a laboratory where the contents of the sample are crushed and thoroughly mixed before a small quantity is analyzed. The above expression is valid for comparing the quantity of an exponentially distributed radioisotope measured by the in situ and the soil sample methods if the following two conditions are satisfied: (a) the concentration of the radioisotope at and below $z_{s}$ is small compared to the quantity of the isotope at the surface and (b) the mean free path of the gamma ray is comparable to or larger than $z_{s}$. In other words, the comparison is only valid if the in situ measurement cannot measure any significant contribution from the radioisotopes below the cutoff depth, and it can measure all of the radioisotopes above the cutoff depth.

Another quantity often used when discussing exponentially distributed radioisotopes is the total activity per unit area. This represents all of the activity in an infinitely deep column of soil and is calculated with the following equation:

$$
S_{A}=\int_{0}^{\infty} S_{E 0} e^{-\alpha z} d z=\frac{S_{E O}}{\alpha}
$$

The value of $a$ is usually poorly known and is highly dependent upon the actual soil conditions and the isotopes which are present. Also, soil disturbance (farming, construction, etc.) will affect the relaxation depth. Variations in $a$ can produce significant changes in the average activity.

\subsection{DISCUSSION OF RESULTS}

\subsection{Experiment \#1 (April)-HPGe In Situ Measurements}

The ${ }^{241} \mathrm{Am}$ and TRU activity measurements made by the Suburban system are listed in Table 1 and shown in Figure 5 where the total activity is expressed in a similar manner to the previously processed aerial data except that the TRU:Am ratio is now 16:1 for both sets of data. The two "rows" of measurements in the southern half of the exclusion area are in the area where the aerial data showed fairly low, uniform activity. Also, several measurements were made in the general area east of the inner fence and along the road between the entrance and $G Z$.

Table 2 summarizes the results of the two hot-spot mining operations. The first mining area shows a reduction in the before-and-after $7.5-\mathrm{m}$ (25-ft) height activity measurements by approximately a factor of 10 (file numbers 2 and 29). The change in activity in the 3-m (10-ft) AGL measurements is only about a factor of two (file numbers 3 and 30 ). The lower height measurement started with a much lower activity and did not see as large an area as the $7.5-\mathrm{m}(25-\mathrm{ft})$ measurement, indicating that most of the hot pieces removed during the mining operation were outside this smaller field-of-view. The second mining location also had a fairly low activity, and even though several small pieces of material were found and removed, the effect of the mining operation wasn't sufficient at this location to overcome the uncertainties from the counting statistics in the 10-minute measurements.

\subsubsection{Suburban Versus Tripod Measurements}

Figures 6-8 (see pages 19 and 20) compare the ${ }^{241} \mathrm{Am}$ activities measured by the Suburban HPGe system operated at 3-m (10-ft) height and the tripod HPGe system operated at $1-\mathrm{m}$ (3-ft) height. The first tripod grid location (see Figure 6) exhibits a relatively uniform, high ${ }^{241} \mathrm{Am}$ activity distribution with a slight increase in activity from the southeast corner to the northwest corner. The Suburban measurement agrees quite well with the individual tripod measurements.

The second grid location (see Figure 7) shows a dramatic increase in ${ }^{241} \mathrm{Am}$ activity from the west side to the east side, and the Suburban measurement seems to be excessively high compared to the tripod measurements. This may be the result of one or more hot pieces just on the edge of the Suburban field-of-view but outside the tripod system fieid-of-view. The circles are a rough indication of the field-of-view of the detector but may not be exactly to scale.

The third grid location (see Figure 8) shows a very hot area in the center of the grid with a much lower, nearly 
Table 1. Suburban Measurements in April. The locations, Am concentrations, and TRU concentrations are shown for the HPGe measurements made at the Double Tracks area. The TRU concentration is based on a $\left({ }^{239} \mathrm{Pu}+{ }^{240} \mathrm{Pu}+{ }^{241} \mathrm{Am}\right):{ }^{241} \mathrm{Am}$ ratio of 16. Positions shown in italics never received a lock on the differential GPS signal, so they have a positional uncertainty on the order of $100 \mathrm{~m}$.

\begin{tabular}{|c|c|c|c|c|c|c|}
\hline \multirow{2}{*}{$\begin{array}{c}\text { File } \\
\text { No. } \\
2\end{array}$} & \multirow{2}{*}{$\begin{array}{l}\text { Latitude (N) } \\
37^{\circ} 42^{\prime} 17.97^{\prime \prime}\end{array}$} & \multirow{2}{*}{$\frac{\text { Longitude (W) }}{116^{\circ} 59^{\prime} 18.28^{\prime \prime}}$} & \multicolumn{2}{|c|}{$\begin{array}{l}{ }^{241} \mathrm{Am} \\
(\mathrm{pCi} / \mathrm{g})\end{array}$} & \multicolumn{2}{|c|}{$\underset{\text { (pCi/g) }}{\text { TRU }}$} \\
\hline & & & 24.43 & \pm 0.68 & 390.9 & \pm 10.9 \\
\hline $3^{a}$ & $37^{\circ} 42^{\prime} 17.92^{\prime \prime}$ & $116^{\circ} 59^{\prime} 18.09^{\prime \prime}$ & 3.12 & \pm 0.44 & .49 .9 & \pm 7.0 \\
\hline 4 & $37^{\circ} 42^{\prime} 13.48^{\prime \prime}$ & $116^{\circ} 59^{\prime} 19.99^{\prime \prime}$ & 33.55 & \pm 0.77 & 536.8 & \pm 12.3 \\
\hline $5^{a}$ & $37^{\circ} 42^{\prime} 13.33^{\prime \prime}$ & $116^{\circ} 59^{\prime} 19.62^{\prime \prime}$ & 39.55 & \pm 0.73 & 632.8 & \pm 11.7 \\
\hline 6 & $37^{\circ} 42^{\prime} 13.48^{\prime \prime}$ & $116^{\circ} 59^{\prime} 21.16^{\prime \prime}$ & 3.09 & \pm 0.54 & 49.4 & \pm 8.6 \\
\hline 7 & $37^{\circ} 42^{\prime} 10.11^{\prime \prime}$ & $116^{\circ} 59^{\prime} 22.96^{\prime \prime}$ & \multicolumn{2}{|c|}{$<\mathrm{MDA}^{\mathrm{b}}$} & \multicolumn{2}{|c|}{$<M^{\prime b}$} \\
\hline 8 & $37^{\circ} 42^{\prime} 9.47^{\prime \prime}$ & $116^{\circ} 59^{\prime} 21.30^{\prime \prime}$ & 6.88 & \pm 0.58 & 110.1 & \pm 9.3 \\
\hline $9^{a}$ & $37^{\circ} 42^{\prime} 9.53^{\prime \prime}$ & $116^{\circ} 59^{\prime} 21.11^{\prime \prime}$ & 5.26 & \pm 0.48 & 84.2 & \pm 7.7 \\
\hline 10 & $37^{\circ} 42^{\prime} 9.13^{\prime \prime}$ & $116^{\circ} 59^{\prime} 19.81^{\prime \prime}$ & 20.13 & \pm 0.67 & 322.1 & \pm 10.7 \\
\hline $11^{a}$ & $37^{\circ} 42^{\prime} 9.20^{\prime \prime}$ & $116^{\circ} 59^{\prime} 19.90^{\prime \prime}$ & 15.89 & \pm 0.56 & 254.2 & \pm 9.0 \\
\hline 12 & $37^{\circ} 42^{\prime} 13.37^{\prime \prime}$ & $116^{\circ} 59^{\prime} 19.65^{\prime \prime}$ & $38: 33$ & \pm 0.78 & 613.3 & \pm 12.5 \\
\hline 22 & $37^{\circ} 42^{\prime} 19.90^{\prime \prime}$ & $116^{\circ} 59^{\prime} 15.43^{\prime \prime}$ & 3.65 & \pm 0.54 & 58.4 & \pm 8.6 \\
\hline 23 & $37^{\circ} 42^{\prime} 20.67^{\prime \prime}$ & $116^{\circ} 59^{\prime} 15.74^{\prime \prime}$ & 7.61 & \pm 0.59 & 121.8 & \pm 9.4 \\
\hline 24 & $37^{\circ} 42^{\prime} 9.47^{\prime \prime}$ & $116^{\circ} 59^{\prime 20.92^{\prime \prime}}$ & 8.22 & \pm 0.58 & 131.5 & \pm 9.3 \\
\hline 25 & $37^{\circ} 42^{\prime} 8.96^{\prime \prime}$ & $116^{\circ} 59^{\prime} 18.20^{\prime \prime}$ & \multicolumn{2}{|c|}{$<\mathrm{MDA}^{\mathrm{b}}$} & \multicolumn{2}{|c|}{$<$ MDA $^{b}$} \\
\hline 26 & $37^{\circ} 42^{\prime} 8.89^{\prime \prime}$ & $116^{\circ} 59^{\prime} 16.34^{\prime \prime}$ & \multicolumn{2}{|c|}{$<\mathrm{MDA}^{\mathrm{b}}$} & \multicolumn{2}{|c|}{$<\mathrm{MDA}^{\mathrm{b}}$} \\
\hline 27 & $37^{\circ} 42^{\prime} 12.62^{\prime \prime \prime}$ & $116^{\circ} 59^{\prime} 15.22^{\prime \prime}$ & \multicolumn{2}{|c|}{$<M^{a b}$} & \multicolumn{2}{|c|}{$<M^{\prime b}$} \\
\hline 28 & $377^{\circ} 13.61^{\prime \prime}$ & $116^{\circ} 59^{\prime} 18.20^{\prime \prime}$ & \multicolumn{2}{|c|}{$<\mathrm{MDA}^{\mathrm{b}}$} & \multicolumn{2}{|c|}{$<\mathrm{MDA}^{\mathrm{b}}$} \\
\hline 29 & $37^{\circ} 42^{\prime} 17.82^{\prime \prime}$ & $116^{\circ} 59^{\prime} 17.43^{\prime \prime}$ & 2.31 & \pm 0.77 & 37.0 & \pm 12.3 \\
\hline $30^{a}$ & $37^{\circ} 42^{\prime} 17.71^{\prime \prime}$ & $116^{\circ} 59^{\prime} 16.87^{\prime \prime}$ & 1.79 & \pm 0.66 & 28.6 & \pm 10.6 \\
\hline 31 & $37042^{\prime 20.34^{\prime \prime}}$ & $116^{\circ} 59^{\prime} 14.36^{\prime \prime}$ & 3.91 & \pm 0.76 & 62.6 & \pm 12.2 \\
\hline 32 & $37^{\circ} 42^{\prime} 21.10^{\prime \prime}$ & $116^{\circ} 59^{\prime} 16.26^{\prime \prime}$ & 23.31 & \pm 0.98 & 373.0 & \pm 15.7 \\
\hline $33^{a}$ & $37^{\circ} 42^{2} 20.07^{\prime \prime}$ & $116^{\circ} 59^{\prime} 16.02^{\prime \prime}$ & 9.07 & \pm 0.73 & 145.1 & \pm 11.7 \\
\hline 34 & $37^{\circ} 42^{\prime} 10.31^{\prime \prime}$ & $116^{\circ} 59^{\prime} 20.50^{\prime \prime}$ & 6.72 & \pm 0.81 & 107.5 & \pm 13.0 \\
\hline 42 & $37^{\circ} 42^{\prime} 20.42^{\prime \prime}$ & $116^{\circ} 59^{\prime} 15.40^{\prime \prime}$ & 8.57 & \pm 0.58 & 137.1 & \pm 9.3 \\
\hline 43 & $37^{\circ} 42^{\prime} 22.16^{\prime \prime}$ & $116^{\circ} 59^{\prime} 15.87^{\prime \prime}$ & 15.51 & \pm 0.63 & 248.2 & \pm 10.1 \\
\hline 44 & $37^{\circ} 42^{\prime} 21.03^{\prime \prime}$ & $116^{\circ} 59^{\prime} 13.64^{\prime \prime}$ & \multicolumn{2}{|c|}{$<\mathrm{MDA}^{\mathrm{b}}$} & \multicolumn{2}{|c|}{$<\mathrm{MDA}^{\mathrm{b}}$} \\
\hline 45 & $377^{\prime} 42^{\prime} 23.99^{\prime \prime}$ & $116^{\circ} 59^{\prime} 14.92^{\prime \prime}$ & 5.58 & \pm 0.56 & 89.3 & \pm 9.0 \\
\hline
\end{tabular}

a Measurements made at a height of $3 \mathrm{~m}$ versus the normal $7.5 \mathrm{~m}$.

- The Minimum Detectable Activity (MDA) is equal to $3 \sigma$ where $\sigma$ is the standard deviation of the counting statistics. For measurements made at a height of $3 \mathrm{~m}$, the MDA is $1.0 \mathrm{pCi} / \mathrm{g}$ of $241 \mathrm{Am}$ and $16.0 \mathrm{pCi} / \mathrm{g}$ of TRU. For measurements made at a height of $7.5 \mathrm{~m}$, the MDA is $1.5 \mathrm{pCi} / \mathrm{g}$ of ${ }^{241} \mathrm{Am}$ and $24.0 \mathrm{pCi} / \mathrm{g}$ of TRU.

uniform concentration around the edge. Here the Suburban measurement appears to be close to an average of the individual tripod measurements, as would be expected if the Suburban detector averages the inner hot spot over its full field-of-view. From these three grid measurements, it is clear that the Am 

DOUBLE TRACKS Site

April Suburban HPGe Data

\begin{tabular}{|c|c|}
\hline COLOR & TRU (pev/g) \\
\hline Black & $<50$ \\
\hline Blue & $50-100$ \\
\hline Green & $100-200$ \\
\hline Yellow & $200-600$ \\
\hline Red & $>600$ \\
\hline \multicolumn{2}{|c|}{$\begin{array}{l}\text {-Ground-based data from Suburban } \\
\text { HPGe system taken at a } 7.5 \text {-meter } \\
\text { height. } \\
\text { Conversion assumptions include: } \\
\text { characterized detector } \\
3-\mathrm{cm} \text { relaxation length } \\
2.5-\mathrm{cm} \text { sample depth } \\
\text { TRU: Am ratio }=16\end{array}$} \\
\hline
\end{tabular}
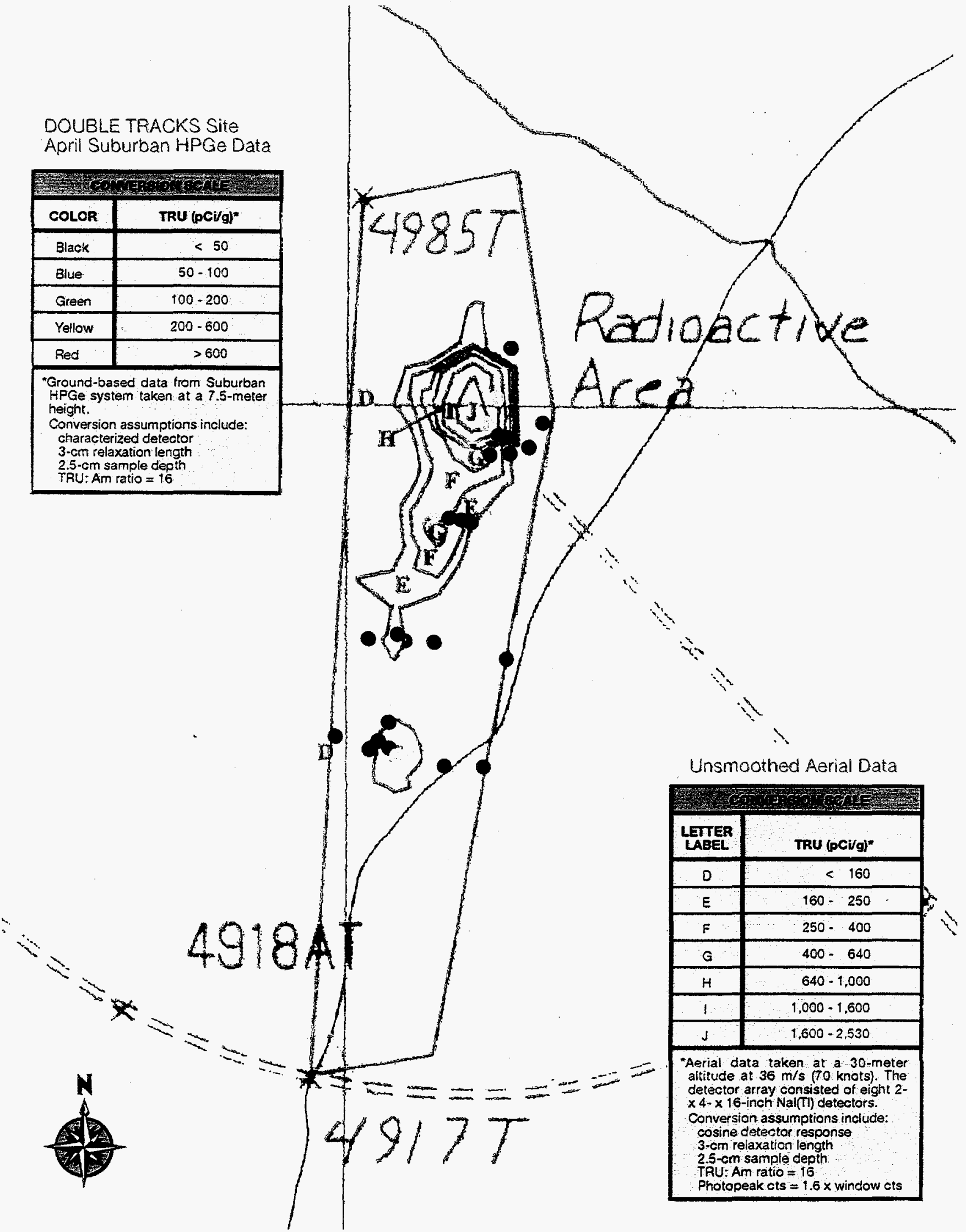

FIGURE 5. MEASUREMENTLOCATIONS OF THE SUBURBAN SYSTEM (APRIL). The locations (by GPS coordinates) of the SUburban measurements are marked by colored dots corresponding to five bands of TRU activity. The contour data from the 1993 aerial survey are included for reference. Both sets of data use the 16:1 TRU: ${ }^{241} \mathrm{Am}$ activity ratio. 

Table 2. "Mining" Location Measurements. The locations and Am concentrations are shown for the HPGe measurements made at the hot-spot mining areas. The TRU concentration is based on a $\left({ }^{239} \mathrm{Pu}+{ }^{240} \mathrm{Pu}+{ }^{241} \mathrm{Am}\right):{ }^{241} \mathrm{Am}$ ratio of 16 . Positions shown in italics never received a lock on the differential GPS signal, so they have a positional uncertainty on the order of $100 \mathrm{~m}$ ( $300 \mathrm{ft})$. The Suburban could easily return to the same location to make the before-and-after measurements. However, knowing its absolute position relative to latitude and longitude is where the positional uncertainty lies. The positions are provided principally to relate this data with the aerial and Kiwi data shown in the later figures.

\begin{tabular}{|c|c|c|c|c|c|c|}
\hline \multirow{2}{*}{$\begin{array}{c}\text { File } \\
\text { No. } \\
\text { First n }\end{array}$} & \multirow{2}{*}{$\frac{\text { Latitude (N) }}{19 \text { location (7.5 }}$} & \multirow{2}{*}{$\frac{\text { Longitude (W) }}{\text { neight) }}$} & \multicolumn{2}{|c|}{$\begin{array}{l}{ }^{241} \mathrm{Am} \\
(\mathrm{pCi} / \mathrm{g})\end{array}$} & \multicolumn{2}{|c|}{$\underset{(\mathrm{pCi} / \mathrm{g})}{\operatorname{TRU}}$} \\
\hline & & & & & & \\
\hline 2 & $377^{\circ} 17.97^{\prime \prime}$ & $116^{\circ} 59^{\prime} 18.28^{\prime \prime}$ & 24.43 & \pm 0.68 & 390.9 & \pm 10.9 \\
\hline 29 & $37^{\circ} 42^{\prime} 17.82^{\prime \prime}$ & $116^{\circ} 59^{\prime} 17.43^{\prime \prime}$ & 2.31 & \pm 0.77 & 37.0 & \pm 12.3 \\
\hline \multicolumn{7}{|c|}{ First mining location (3-m height) } \\
\hline 3 & $37^{\circ} 42^{\prime} 17.92^{\prime \prime}$ & $116^{\circ} 59^{\prime} 18.09^{\prime \prime}$ & 3.12 & \pm 0.44 & 49.9 & \pm 7.0 \\
\hline 30 & $37^{\circ} 42^{\prime} 17.71^{\prime \prime}$ & $116^{\circ} 59^{\prime} 16.87^{\prime \prime}$ & 1.79 & \pm 0.66 & 28.6 & \pm 10.6 \\
\hline \multicolumn{7}{|c|}{ Second mining location (7.5-m height) } \\
\hline 22 & $37^{\circ} 42^{\prime} 19.90^{\prime \prime}$ & $116^{\circ} 59^{\prime} 15.43^{\prime \prime}$ & 3.65 & \pm 0.54 & 58.4 & \pm 8.6 \\
\hline 31 & $37^{\circ} 42^{\prime 20} .34^{\prime \prime}$ & $116^{\circ} 59^{\prime} 14.36^{\prime \prime}$ & 3.91 & \pm 0.76 & 62.6 & \pm 12.2 \\
\hline
\end{tabular}

distribution varies dramatically over distances of several meters (comparable to the fields-of-view of these detector systems).

\subsubsection{Measurements South of the Exclusion Fence}

Figure 9 (see page 21) shows the tripod measurements made south of the fence. Using the intersection of an arc road with an arroyo as a reference point (marked "REF." in figure), it was possible to establish the position and direction of the actual survey line after the measurements were completed. Measurements were made at distances of $6,230,460,690$, and 910 $\mathrm{m}(20,750,1,500,2,250$, and $3,000 \mathrm{ft})$ south of the fence. At the 910-m distance, measurements were made in an east and west direction at distances of 46 and $91 \mathrm{~m} \mathrm{(150} \mathrm{and} 300 \mathrm{ft}$ ). The aerial data shown in this figure has been averaged over nine neighboring data points to produce a map of the lowest possible detectable activity of ${ }^{241} \mathrm{Am} .{ }^{5}$

In comparing the data, it is important to take into account the difference in the area measured by each system. The in situ detector, mounted on a short tripod only $56 \mathrm{~cm}$ ( 22 in) above the ground, provides an average concentration value over an area approximately

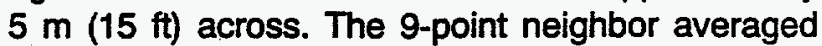
aerial data, taken at a survey altitude of $30 \mathrm{~m}(100 \mathrm{ft})$ and a 46-m (150-ft) grid spacing, provides an average concentration value over an area about $150 \mathrm{~m}$ (500 ft) in diameter. Near the fence, the in situ data shows higher levels than indicated by the aerial data. This would indicate that the width of the plume at this location is smaller than the field-of-view of the aerial system. The aerial system would show a narrow plume as covering a larger area but at a lower concentration value than actually exists on the ground. Further out from the fence, the two sets of data agree better. This would indicate that the plume is more dispersed and covers a wider area here than closer to the fence.

Both sets of data in Figure 9 used an assumed Pu:Am ratio of 10. Measurements made in April, as well as theoretical calculations, indicate that this value is too low. As discussed in this report, a value of 16 will be used for the total alpha-emitting TRU:Am ratio for this site. Therefore, all data in Figure 9, both aerial and ground-based, should be multiplied by 1.6 before comparing to TRU data presented elsewhere. 


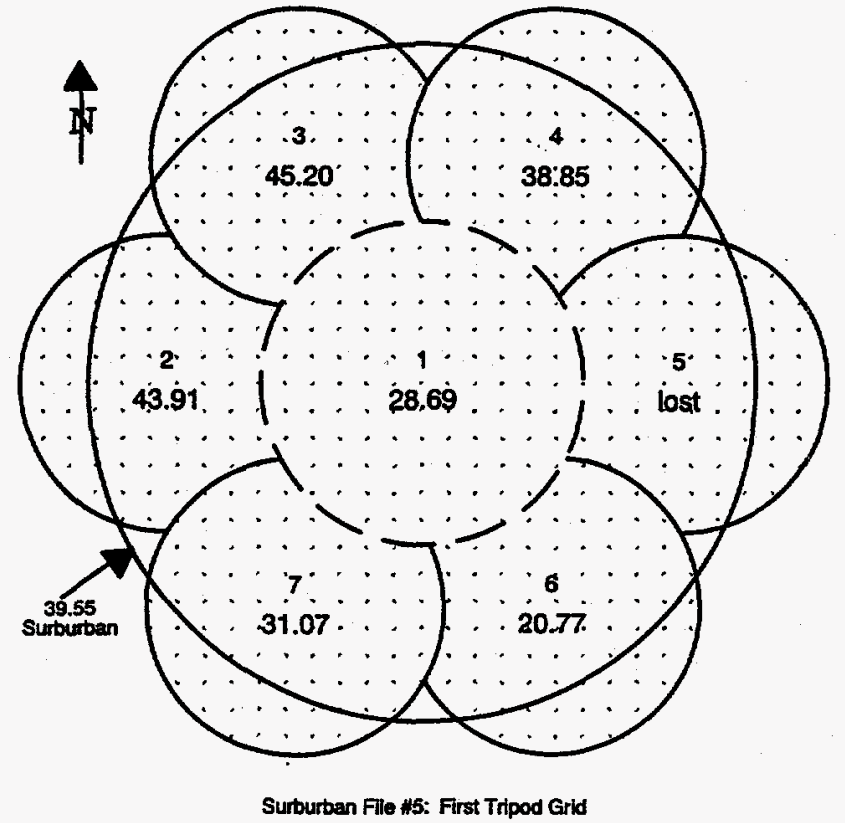

FIGURE 6. SUBURBAN VERSUS TRIPOD MEASURE. MENTS-FIRSTLOCATION. The241Amsoilactivity concentrations ( $\mathrm{pCi} / \mathrm{g}$ ) as measured by the Suburban HPGe detector at a 3-m height versus the tripod detectormeasurements at 1-m height. Note the general increase in activity from the southeast corner to the northwest corner. Data from footprint \#5 was inadvertently not written to tape and the omission was not detected until after the survey team had left the field.

\subsubsection{Highest Concentration of TRU Activity}

As discussed in the next section, two different HPGe detectors made measurements on the mound to assess the Pu:Am ratio. Although the experiments were designed for the less stringent requirement of calculating the Pu:Am ratio, the activity of the soil on the mound can be deduced from these measurements if a few more assumptions are included.

The first detector system made measurements in both collimated and uncollimated arrangements. The uncollimated measurements should be ignored since the detector could see a significant amount of area away from the mound. The collimated measurements provide a more accurate measurement of only the soil on the mound and produce an ${ }^{241} \mathrm{Am}$ activity in the range $1,900-2,800 \mathrm{pCi} / \mathrm{g}$, depending on the assumption of the depth to which the Am is distributed. The second detector system had a slightly different collimation arrangement and deduced an activity of

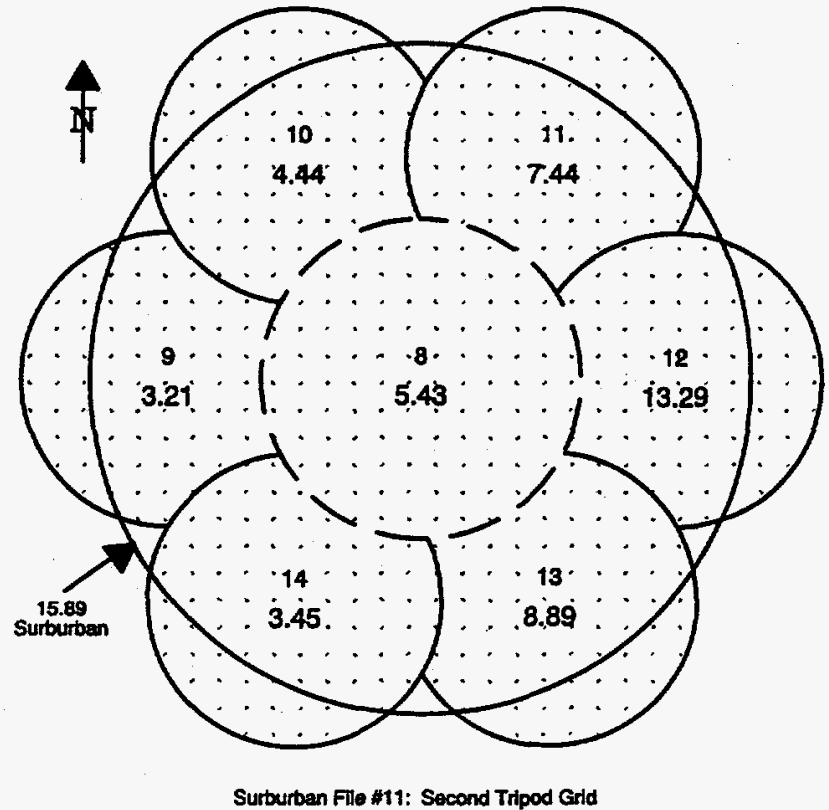

FIGURE 7. SUBURBAN VERSUS TRIPOD MEASUREMENTS-SECOND LOCATION. The 241Am SOI activity concentrations ( $\mathrm{pCi} / \mathrm{g}$ ) as measured by the Suburban HPGe detector at a 3-m height versus the tripod detector measurements at 1-m height. Note the dramatic increase in activity from west to the east.

about $2,500 \mathrm{pCi} / \mathrm{g}$. Multiplying these numbers by the TRU:Am ratio of $16: 1$ yields a TRU activity of $30,000-45,000 \mathrm{pCi} / \mathrm{g}$ for the first system and 40,000 $\mathrm{pCi} / \mathrm{g}$ for the second system. Since TRU waste is defined as having a total activity greater than 100,000 $\mathrm{pCi} / \mathrm{g}$ (see DOE Order $5820.2 \mathrm{~A}$ ), the hottest portion of the mound does not exceed this level (when averaged over the field-of-view of the tripod system).

During the June expedition (see Section 6.7), measurements of individual $300-800-\mathrm{g}$ soil samples from the mound and surrounding area produced TRU activities of $100,000-800,000 \mathrm{pCi} / \mathrm{g}$. The HPGe detectors viewed an area of ground much larger than these soil samples and, as observed throughout the two expeditions, the Pu and Am contamination is not dispersed in a uniform pattern.

The activity results are close enough to the TRU limit that several ideas were proposed to ensure that the total activity of any truckload of soil removed from the Double Tracks site would not exceed the TRU limit. One of the principal means of reducing the total activity of the soil was to remove the hot pieces coated with $\mathrm{Pu}$. This would make a small amount of TRU, but the 


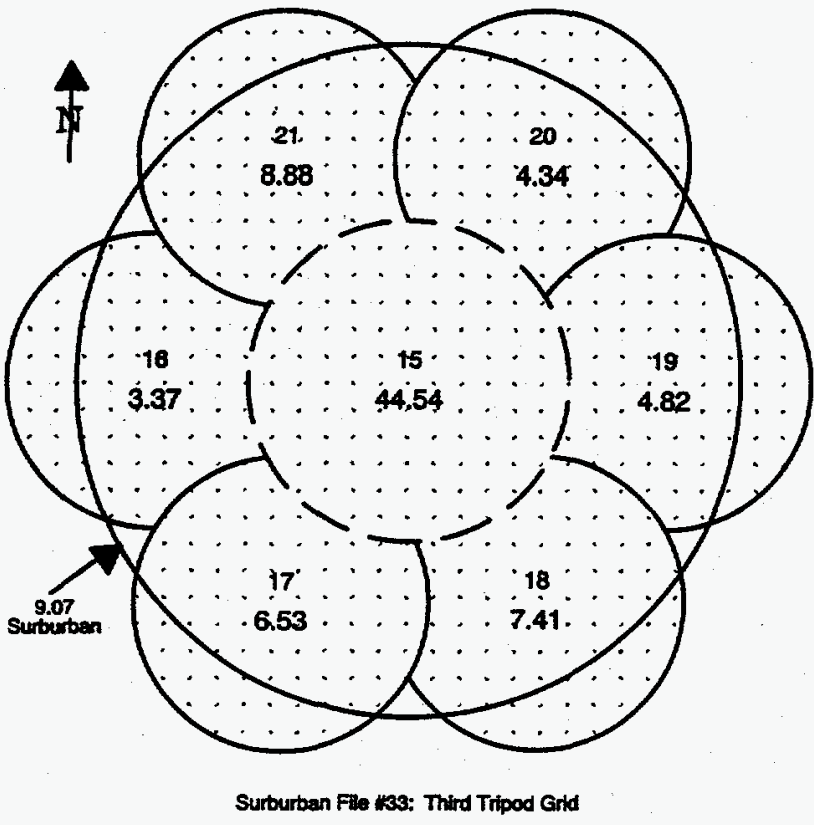

FIGURE 8. SUBURBAN VERSUS TRIPOD MEASURE. MENTS-THIRD LOCATION. The 241AM SOII activity concentrations ( $\mathrm{pCi} / \mathrm{g}$ ) as measured by the Suburban HPGe detector at a 3-m height versus the tripod detector measurements at 1-m height. Note the high concentration only in the center of the figure with the outer circles having much less.

many truckloads of soil would certainly be below the limit. This desire to locate the hot pieces and the success of the "mining" of the hot spots found with the hand-held FIDLER detectors were the major impetus behind the ATV hot-spot search in June.

\subsection{Experiment \#2 (April)-Pu:Am Ratio Measurements}

For the two methods of measurement, the analysis was performed independently. The ratio calculation is based on measuring the $60-\mathrm{keV}$ gamma rays emitted by ${ }^{241} \mathrm{Am}$ and three of the gamma rays emitted by ${ }^{239} \mathrm{Pu}$ ( $129 \mathrm{keV}, 375 \mathrm{keV}$, and $414 \mathrm{keV}$. Within statistical uncertainties, the ratio of the Am activity relative to the Pu activities calculated from each of its gamma rays should be the same. There are differences in the activities of the two methods, principally as a result of different assumptions about the source-depth distribution, counting statistics, detector characterization, etc. As noted earlier, the attempt to measure the
39- and 51-keV X-rays from ${ }^{239} \mathrm{Pu}$ was unsuccessful, as the large Compton background from the ${ }^{241} \mathrm{Am}$ gamma rays nearly obliterated these $X$-ray peaks.

The results of the first method of measuring this ratio are presented in Table 3 (see page 22). A relaxation length of $20 \mathrm{~cm}$ (8 in) was assumed for the vertical distribution of ${ }^{241} \mathrm{Am}$. The top portion of the table presents the average activity levels for the three sampling depths of $2.5,5$, and $20 \mathrm{~cm}$. Only the longest time measurements for each arrangement are shown since the only change is a very slight improvement in counting statistics with the increasing time of the measurement. The Pu:Am ratio and the uncertainty in this ratio (based only on the counting statistics) are presented in the bottom portion of the table.

For the uncollimated data, the detector "sees" the Pu gamma rays from a larger area than it sees the Am gamma rays. Thus the $\mathrm{Pu}$ activities and the Pu:Am ratios for the uncollimated detector are too high. The collimators used in these measurements are very efficient at removing gamma rays at $60 \mathrm{keV}$ but not as efficient at higher energies such as the gamma rays from ${ }^{239} \mathrm{Pu}$. To reach the same fractional attenuation, about twice as much material (air, soil, $\mathrm{Pb}$, etc.) is needed to attenuate the 129-keV gamma rays by the same fraction as the $60-\mathrm{keV}$ gamma rays and about three times as much material for the 375- and 414-keV gamma rays. These measurements also are probably too high since a nontrivial fraction of the higher-energy Pu gamma rays can reach the detector after passing through the side of the collimator, while the Am gamma rays are completely attenuated.

Results for the second ratio measurement method, using the highly collimated HPGe detector, are given in Table 4 (see page 23) for both the 300- and 600 -second measurements. Activity values, in $\mathrm{pCi} / \mathrm{g}$, are given for both $\mathrm{Am}$ and $\mathrm{Pu}$, as determined from each individual gamma ray. The bottom of Table 4 shows the resulting ratios of ${ }^{239} \mathrm{Pu}:{ }^{241} \mathrm{Am}$ derived from each of the Pu gamma-ray lines. Ratios vary as a result of counting statistics in analyzing each gamma-ray photopeak, as well as the uncertainty in the depth distribution.

Table 5 (see page 24) shows the theoretical ratios due to decay from the original mixture of the Pu supposedly used in the test. Averaging the results from all three Pu gamma rays and from both the 300 - and 600 -second acquisitions leads to values of $14.91(1 / \alpha$ $=3 \mathrm{~cm}), 12.36(1 / \alpha=20 \mathrm{~cm})$, and $11.72(1 / \alpha=$ 



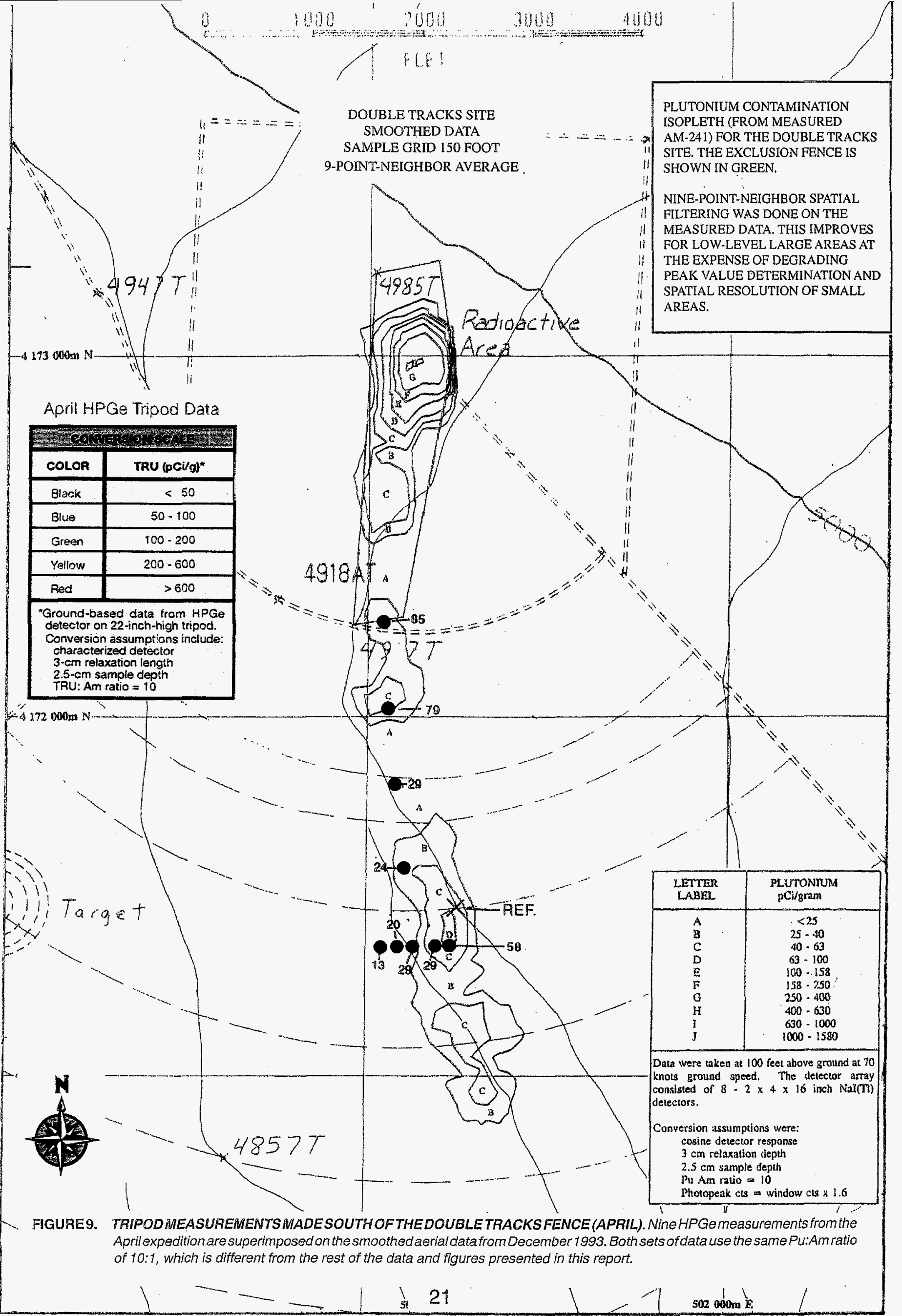



Table 3. Pu:Am Ratio Measurements for the First Method. The Pu:Am ratio is an average of the ratios based on the $60-\mathrm{keV}^{241} \mathrm{Am}$ photopeak and three of the gamma-ray photopeaks from ${ }^{239} \mathrm{Pu}$. Since these measurements were made on the mound near GZ, the calculations in this table assume a nearly uniform depth distribution (exponential distribution using a relaxation length of $20 \mathrm{~cm}[8 \mathrm{in}]$ ). Activity results for three different sampling depths are presented; the ratio calculations do not depend on the sampling depth.

\begin{tabular}{|c|c|c|c|c|c|c|}
\hline & \multicolumn{3}{|c|}{$\begin{array}{l}\text { Uncollimated (1800 s) } \\
\text { Sampling Depth }(\mathrm{cm})\end{array}$} & \multicolumn{3}{|c|}{$\begin{array}{l}\text { Collimated }(3000 \mathrm{~s}) \\
\text { Sampling Depth }(\mathrm{cm})\end{array}$} \\
\hline & 2.5 & 5 & 20 & 2.5 & 5 & 20 \\
\hline \multicolumn{7}{|c|}{ Average activity (pCi/g) } \\
\hline $60 \mathrm{keV}$ & 1,925 & 1,812 & 1,294 & 2,820 & 2,654 & 1,896 \\
\hline $129 \mathrm{keV}$ & 32,669 & 30,750 & 21,968 & 42,797 & 40,283 & 28,779 \\
\hline $375 \mathrm{keV}$ & 29,601 & 27,862 & 19,906 & 36,780 & 34,619 & 24,733 \\
\hline $414 \mathrm{keV}$ & 31,381 & 29,538 & 21,102 & 34,774 & 32,731 & 23,384 \\
\hline \multicolumn{7}{|c|}{ Pu:Am ratios for each $239 \mathrm{Pu}$ gamma ray relative to ${ }^{241} \mathrm{Am}$} \\
\hline & Ratio & \multicolumn{2}{|c|}{ Uncertainty } & Ratio & \multicolumn{2}{|c|}{ Uncertainty } \\
\hline $129 \mathrm{keV}$ & 16.97 & \multicolumn{2}{|c|}{ \pm 0.24} & 15.18 & \multicolumn{2}{|c|}{ \pm 0.24} \\
\hline $375 \mathrm{keV}$ & 15.38 & \multicolumn{2}{|c|}{ \pm 0.51} & 13.04 & \multicolumn{2}{|c|}{ \pm 0.54} \\
\hline $414 \mathrm{keV}$ & 16.30 & \multicolumn{2}{|c|}{ \pm 0.57} & 12.33 & \multicolumn{2}{|c|}{ \pm 0.56} \\
\hline Average & 16.21 & \multicolumn{2}{|c|}{ \pm 0.81} & 13.52 & \multicolumn{2}{|c|}{ \pm 0.86} \\
\hline
\end{tabular}

$100 \mathrm{~cm})$. These results are in general agreement with the theoretical prediction of 12.53 from Table 5. The results show closer agreement for the deeper depth distributions, which are more likely in the case of contamination within the mound soil. Based on these results, the information presented in Table 5 should provide a reasonable estimate for the appropriate ratio data.

In analyzing risk associated with Pu contamination in soil, it is usual to include activity levels of all significant alpha-emitting isotopes. Alpha emitters are of most concern since inhalation into the lungs is the path leading to the highest potential dose from Pu-contaminated soil. For Pu contamination, the isotopes of concern are ${ }^{239} \mathrm{Pu},{ }^{240} \mathrm{Pu}$, and ${ }^{241} \mathrm{Am}$. These are usually combined and referred to as the total TRU alpha emitters.

Table 5 gives a $239-240 \mathrm{Pu}:{ }^{241}$ Am ratio of 100/7.291645 $=13.71$ which, when the Am is added, yieids a TRU: ${ }^{241} \mathrm{Am}$ ratio of 14.71. Due to potential differences in migration of $\mathrm{Pu}$ and $\mathrm{Am}$ in the soil, the actual in situ ratio may vary somewhat from the theoretical prediction. In order to account for potential uncertainties in the actual ratio currently existing at Double Tracks, a value of 16 is recommended for use in determining concentration values from the ${ }^{241} \mathrm{Am}$ measurements. This is approximately $10 \%$ higher than the theoretical prediction and provides a reasonable margin of error for uncertainties in the actual ratio.

\subsection{Experiment \#3 (April)-Depth Profiling Measurements}

\subsubsection{Side Wall Measurements with TLD Material}

Of the three measurements made near the inner fence, the first two were in areas that showed little or no elevated activity with a FIDLER. The FIDLER measurements were not made until after the first two sets of TLD material had been placed. As expected, results from these sheets showed basically background activity. The third set was placed in an area of elevated activity as identified with a FIDLER. The 
Table 4. Pu:Am Ratio Measurements for the Second Method. The Pu:Am ratio is an average of the ratios based on the $60-\mathrm{keV}^{241} \mathrm{Am}$ photopeak and three of the gamma-ray photopeaks from ${ }^{239} \mathrm{Pu}$. These measurements were made with a highly collimated $\mathrm{HPGe}$ detector placed on the mound at GZ. Activity values and the corresponding ratios for three different relaxation lengths are presented.

\begin{tabular}{|c|c|c|c|c|c|c|}
\hline & \multicolumn{3}{|c|}{$\begin{array}{c}300 \text { Second Data } \\
\text { Relaxation Length }(\mathrm{cm})\end{array}$} & \multicolumn{3}{|c|}{$\begin{array}{c}600 \text { Second Data } \\
\text { Relaxation Length }(\mathrm{cm})\end{array}$} \\
\hline & 3 & 20 & 100 & 3 & 20 & 100 \\
\hline \multicolumn{7}{|c|}{ Average activity (pCi/g) } \\
\hline $60 \mathrm{keV}$ & 2,584 & 2,860 & 2,883 & 2,308 & 2,556 & 2,576 \\
\hline $129 \mathrm{keV}$ & 36,826 & 36,360 & 35,544 & 40,442 & 39,930 & 39,035 \\
\hline $375 \mathrm{keV}$ & 30,899 & 27,397 & 25,865 & 33,708 & 29,887 & 28,216 \\
\hline $414 \mathrm{keV}$ & 39,620 & 34,689 & 32,606 & 36,343 & 31,820 & 29,909 \\
\hline \multicolumn{7}{|c|}{ Pu:Am ratios for each ${ }^{239} \mathrm{Pu}$ gamma ray relative to ${ }^{241} \mathrm{Am}$} \\
\hline $129 \mathrm{keV}$ & 14.25 & 12.71 & 12.33 & 17.52 & 15.62 & 15.15 \\
\hline $375 \mathrm{keV}$ & 11.96 & 9.58 & 8.97 & 14.60 & 11.69 & 10.95 \\
\hline $414 \mathrm{keV}$ & 15.33 & 12.13 & 11.31 & 15.75 & 12.45 & 11.61 \\
\hline Average & 13.85 & 11.47 & 10.87 & 15.96 & 13.25 & 12.57 \\
\hline \multicolumn{4}{|c|}{ Average of $300-$ and $600-$ second results } & 14.91 & 12.36 & 11.72 \\
\hline
\end{tabular}

surface sheet showed several hot spots with most of the area exhibiting background levels. The vertical sheet also showed several hot spots but with no real continuum that would lead to a profile. One hot spot was found near the surface and another approximately $10 \mathrm{~cm}$ ( $4 \mathrm{in}$ ) below the surface. It is most likely that the hot spot below the surface was transported there by the shovel in trying to make the side wall to sample.

The TLD material is quite valuable for showing the distribution of activity with a very high spatial resolution (1mm [0.04 in]). For depth profile studies, however, the method used to form a side wall can influence the results. Similar conclusions were reached by ORNL in their attempt to use a track etch detector for measuring alpha contamination. Although in theory the technique should work, in practice, the direct HPGe measurement technique appears to be a better solution.

\subsubsection{Comparison Between the Pu X-Rays and the 241 Am Gamma Ray}

As expected based on the FIDLER readings, no Am activity was measured at the first two TLD measurement locations. The remaining sites showed the $60-\mathrm{keV}$ gamma ray but no evidence of any $X$-rays. This included an extremely hot area near the mound which contained sufficient activity to allow direct measurements of the gamma rays from ${ }^{239} \mathrm{Pu}$.

The lack of any $X$-rays likely resulted from three reasons: (a) the attenuation in soil, (b) the very small area actually being measured, and (c) the height of the detector above the ground. Because the collimator limited the field-of-view to a 10-cm- (4-in-) diameter circle, the actual amount of soil being measured was quite small. In addition, the detector was approximately $60 \mathrm{~cm}$ (24 in) above the ground. Even for the 60-keV gamma ray, only a weak signal was obtained in three of the four locations where elevated activity was measured. A better approach probably would have been to put the detector, with its sides collimated, right on the ground. This would have greatly increased the signal from the $60-\mathrm{keV}$ gamma ray and might have shown the $X$-rays. This method definitely 
Table 5. Pu:Am Ratio Calculations from Initial Composition. The Pu:Am ratio shown here is a simple decay of the Pu and Am isotopes in the initial composition. The ratio is shown as a percentage of Am:Pu, rather than as a Pu:Am ratio as in the rest of this report.

\begin{tabular}{|c|c|c|c|c|c|c|c|c|c|}
\hline & & & ${ }^{238} \mathrm{Pu}$ & $239 \mathrm{Pu}$ & $240 \mathrm{Pu}$ & ${ }^{241} \mathrm{Pu}$ & $242 p u$ & ${ }^{241} \mathrm{Am}$ & Total \\
\hline \multicolumn{3}{|c|}{ Mol, Weight (g) } & 238 & 239 & 240 & 241 & 242 & 241 & \\
\hline \multicolumn{3}{|c|}{ Mass Fraction } & $3.9 E-05$ & 0.97314 & 0.0253 & 0.001487 & 3.1E-05 & 0 & 0.999997 \\
\hline \multicolumn{3}{|c|}{ Half Lifo (yrs) } & 87.75 & 24131 & 6569 & 14.4 & 376000 & 432 & \\
\hline \multicolumn{3}{|c|}{ Lambda (per yr) } & 0.007899 & $2.9 E-05$ & 0.000106 & 0.048135 & $1.8 E-06$ & 0.001605 & \\
\hline \multicolumn{2}{|c|}{$(C \mathrm{v} / \mathrm{g})$ of $P u+A m(t=0)$} & & 0.000662 & 0.0603 & 0.005735 & 0.153124 & $1.2 E-07$ & 0.000974 & 0.220795 \\
\hline \multicolumn{2}{|c|}{ Activity Fraction } & & 0.002999 & 0.273102 & 0,025974 & & $5.5 E-07$ & 0.004411 & \\
\hline \multicolumn{10}{|c|}{ Note: All activities are nuclear transformation rates, not particle emission rates. } \\
\hline \multicolumn{8}{|c|}{ Curies from $1 \mathrm{Ci}$ of Pu+Am Mixture } & $\begin{array}{l}241 \mathrm{Am}: \\
229 \mathrm{Pu}\end{array}$ & $\begin{array}{c}241 \mathrm{Am:} \\
(239,240 \mathrm{Pu})\end{array}$ \\
\hline Time & Year & 238Pu & ${ }^{239} \mathrm{Pu}$ & $240 \mathrm{Pu}$ & ${ }^{241} \mathrm{Pu}$ & 242Pu & 241 Am & $\begin{array}{l}\% \text { Activity } \\
\text { Ratio }\end{array}$ & $\begin{array}{l}\text { \% Activity } \\
\text { Ratio }\end{array}$ \\
\hline 0 & 1963 & 0.002999 & 0.273102 & 0.025974 & 0.693513 & $5.5 E-07$ & 0.004411 & 1.615281 & 1.475 \\
\hline 1 & 1964 & 0.002976 & 0.273094 & 0.025971 & 0.660921 & 5.5E-07 & 0.00549 & 2.010224 & 1.835656 \\
\hline 2 & 1965 & 0.002952 & 0.273087 & 0.025968 & 0.629861 & 5.5E-07 & 0.006516 & 2.385876 & 2.1787 \\
\hline 3 & 1966 & 0.002929 & 0.273079 & 0.025965 & 0.600261 & 5.5E-07 & 0.007491 & 2.743144 & 2.504962 \\
\hline 4 & 1967 & 0.002906 & 0.273071 & 0.025963 & 0.572052 & 5.5E-07 & 0.008418 & 3.082893 & 2.81523 \\
\hline 5 & 1968 & 0.002883 & 0.273063 & 0.02596 & 0.545168 & $5.5 E-07$ & 0.0093 & 3.405947 & 3.110257 \\
\hline 6 & 1969 & 0.00286 & 0.273055 & 0.025957 & 0.519548 & $5.5 E-07$ & 0.010139 & 3.713092 & 3.390759 \\
\hline 7 & 1970 & 0.002838 & 0.273047 & 0.025954 & 0.495131 & $5.5 E-07$ & 0.010936 & 4.005075 & 3.657419 \\
\hline 8 & 1971 & 0.002816 & 0.273039 & 0.025952 & 0.471863 & $5.5 E-07$ & 0.011693 & 4.282609 & 3.910889 \\
\hline 9 & 1972 & 0.002793 & 0.273032 & 0.025949 & 0.449688 & $5.5 E-07$ & 0.012413 & 4.546376 & 4.151789 \\
\hline 10 & 1973 & 0.002771 & 0.273024 & 0.025946 & 0.428554 & $5.5 E-07$ & 0.013097 & 4.797022 & 4.38071 \\
\hline 11 & 1974 & 0.00275 & 0.273016 & 0.025944 & 0.408414 & $5.5 E-07$ & 0.013747 & 5.035165 & 4.598216 \\
\hline 12 & 1975 & 0.002728 & 0.273008 & 0.025941 & 0.389221 & $5.5 E-07$ & 0.014364 & 5.261393 & 4.804844 \\
\hline 13 & 1976 & 0.002707 & 0.273 & 0.025938 & 0.37093 & $5.5 E-07$ & 0.01495 & 5.476267 & 5.001106 \\
\hline 14 & 1977 & 0.002685 & 0.272992 & 0.025935 & 0.353498 & 5.5E-07 & 0.015507 & 5.680321 & 5.18749 \\
\hline 15 & 1978 & 0.002664 & 0.272985 & 0.025933 & 0.336885 & $5.5 E-07$ & 0.016035 & 5.874066 & 5.364461 \\
\hline 16 & 1979 & 0.002643 & 0.272977 & 0.02593 & 0.321053 & $5.5 E-07$ & 0.016537 & 6.057985 & 5.532461 \\
\hline 17 & 1980 & 0.002622 & 0.272969 & 0.025927 & 0.305965 & 5.5E-07 & 0.017013 & 6.232542 & 5.691913 \\
\hline 18 & 1981 & 0.002602 & 0.272961 & 0.025924 & 0.291586 & 5.5E-07 & 0.017465 & 6.398178 & 5.84322 \\
\hline 19 & 1982 & 0.002581 & 0.272953 & 0.025922 & 0.277883 & $5.5 E-07$ & 0.017893 & 6.555313 & 5.986765 \\
\hline 20 & 1983 & 0.002561 & 0.272945 & 0.025919 & 0.264824 & $5.5 E-07$ & 0.018299 & 6.704346 & 6.122914 \\
\hline 21 & 1984 & 0.002541 & 0.272938 & 0.025916 & 0.252379 & $5.5 E-07$ & 0.018684 & 6.845661 & 6.252015 \\
\hline 22 & 1985 & 0.002521 & 0.27293 & 0.025913 & 0.240518 & $5.5 E-07$ & 0.019049 & 6.97962 & 6.374399 \\
\hline 23 & 1986 & 0.002501 & 0.272922 & 0.025911 & 0.229215 & $5.5 E-07$ & 0.019395 & 7.10657 & 6.490384 \\
\hline 24 & 1987 & 0.002481 & 0.272914 & 0.025908 & 0.218443 & $5.5 E-07$ & 0.019723 & 7.226841 & 6.600272 \\
\hline 25 & 1988 & 0.002462 & 0.272906 & 0.025905 & 0.208177 & $5.5 E-07$ & 0.020033 & 7.340749 & 6.704348 \\
\hline 26 & 1989 & 0.002442 & 0.272898 & 0.025903 & 0.198394 & $5.5 E-07$ & 0.020327 & 7.448593 & 6.802888 \\
\hline 27 & 1990 & 0.002423 & 0.272891 & 0.0259 & 0.18907 & $5.5 E-07$ & 0.020605 & 7.550659 & 6.896152 \\
\hline 28 & 1991 & 0.002404 & 0.272883 & 0.025897 & 0.180185 & 5.5E-07 & 0.020868 & 7.647219 & 6.984389 \\
\hline 29 & 1992 & 0.002385 & 0.272875 & 0.025894 & 0.171717 & $5.5 E-07$ & 0.021117 & 7.738534 & 7.067836 \\
\hline 30 & 1993 & 0.002366 & 0.272867 & 0.025892 & 0.163647 & $5.5 E-07$ & 0.021351 & 7.824851 & 7.146719 \\
\hline 31 & 1994 & 0.002348 & 0.272859 & 0.025889 & 0.155957 & $5.5 E-07$ & 0.021573 & 7.906406 & 7.221254 \\
\hline 32 & 1995 & 0.002329 & 0.272851 & 0.025886 & 0.148627 & $5.5 E-07$ & 0.021783 & 7.983423 & 7.291645 \\
\hline 33 & 1996 & 0.002311 & 0.272843 & 0.025883 & 0.141643 & 5.5E-07 & 0.021981 & 8.056116 & 7.358089 \\
\hline 34 & 1997 & 0.002293 & 0.272836 & 0.025881 & 0.134986 & $5.5 E-07$ & 0.022167 & 8.124691 & 7.420771 \\
\hline 35 & 1998 & 0.002275 & 0.272828 & 0.025878 & 0.128642 & $5.5 E-07$ & 0.022343 & 8.189341 & 7.47987 \\
\hline 36 & 1999 & 0.002257 & 0.27282 & 0.025875 & 0.122597 & $5.5 E-07$ & 0.022508 & 8.250252 & 7.535554 \\
\hline 37 & 2000 & 0.002239 & 0.272812 & 0.025872 & 0.116835 & $5.5 E-07$ & 0.022664 & 8.307601 & 7.587985 \\
\hline 38 & 2001 & 0.002222 & 0.272804 & 0.02587 & 0.111345 & $5.5 E-07$ & 0.022811 & 8.361555 & 7.637317 \\
\hline 39 & 2002 & 0.002204 & 0.272796 & 0.025867 & 0.106112 & 5.5E-07 & 0.022948 & 8.412276 & 7.683696 \\
\hline
\end{tabular}


did not work as implemented. A modified version might be successful if the activity is very shallow. There appears to be no reason for further work in this area as the probability of success seems quite low.

\subsubsection{Direct HPGe Measurements}

Although not providing as fine a spatial resolution as possible with the TLD material, this is a very simple technique for field use. Results from these measurements showed that most of the activity was in the top 2-4-cm (1-2-in) region with one location exhibiting activity down to $8 \mathrm{~cm}$ (about 3 in). This shallow distribution is typical of that found for $\mathrm{Pu}$ in undisturbed areas. Additional time should be spent developing optimum methods to remove soil in thin layers. (It took several attempts to consistently remove a thin layer of soil; the first several attempts were almost always too deep.) Some additional work should also be done to determine the best detector height and field-of-view combination. Assuming 5-minute measurements, this method can provide a good estimate of the depth of contamination within approximately $\mathbf{3 0}$ minutes. This is far superior to the time and cost of obtaining profile samples and analyzing them in a remote laboratory. The method would be more tedious, and likely not as successful, for contaminants that are distributed more deeply into the soil, such as ${ }^{137} \mathrm{Cs}$ from typical worldwide fallout.

\subsection{Experiment \#4 (June)-ATV Hot-Piece Search}

The ATV system was very successful in locating small areas of elevated activity which could then be surveyed with hand-held FIDLER detectors to find the hot piece. No recordable data were collected with this system; this was strictly a search and mark experiment (although the miners were able to show that these small areas could be cleaned up). The search was conducted as a series of east-west paths and covered the area from a little more than $150 \mathrm{~m}$ (500 it) south of $G Z$ to about $60 \mathrm{~m}(200 \mathrm{ft})$ north of $\mathrm{GZ}$.

Since the ATV hot-piece search and the Kiwi survey (below) were conducted in parallel, some of the pieces found and removed during the ATV search had been detected earlier by the Kiwi. Therefore the small hot spots within the above distance limits from GZ and present in the Kiwi plots shown later in this report should be considered as already removed during the
ATV search and not as areas which need further cleanup.

\subsection{Experiment \#5 (June)-Kiwi Survey Measurements}

The results of the Kiwi survey are displayed in Figures 10-13 (see pages 26-29). Figure 10 presents both the gross count and TRU activity levels on the original second-by-second locations. The ${ }^{241} \mathrm{Am}$ activity is calculated from each spectrum by extracting the net counts in a window around the 60-keV photopeak. The TRU activity is calculated from the ${ }^{241} \mathrm{Am}$ activity by multiplying by the TRU:241 Am ratio of $16: 1$ described in Section 6.2. In addition to the colorcoded points, the "flight" lines traveled by the Kiwi vehicle are clearly traceable over most of the area.

The individual second-by-second measurements are displayed as small squares which, in this display, are just slightly smaller than the actual footprint of the measurement. The displayed squares are about $2 \mathrm{~m}$ $(7-8 \mathrm{ft})$ in length. The detector footprint is closer to 3 $\mathrm{m}(10 \mathrm{ft})$ perpendicular to the direction of travel. Along the vehicle path, the detector footprint varies with the speed of the vehicle but, in any case, would provide continuous coverage of the ground along the direction of travel. Thus the only real gaps in the coverage are those between the flight lines. Where the flight lines intersect, it is not always easy from this display to separate which set of data belongs to which flight line.

Of major interest in Figure 10 is the large hole in the data as the Kiwi had to avoid driving over the mound and the small depression just northeast of the mound. In later analysis, a linear interpolation of the measured activity filled this gap. The main effect of the linear interpolation is that, in later plots, the hottest activity location appears just east of the mound rather than on top of it. Other instrument surveys (mainly hand-held FIDLERs) indicated higher activity just east of the mound, although their results were not recorded.

Figure 11 shows the results of collecting all of the individual second-by-second measurements into a nominal 9-m (30-ft) grid and averaging the data over this interval. This plot presents the gross count data which is simply a sum of all of the gamma rays detected in each spectrum. As expected for a region this small, the gross count activity outside the area of actual contamination is quite uniform (varying by only $5 \%$ ). The lack of data over the mound and the resulting linear interpolation caused the highest contour level to appear over the flight line closest to the mound on the 
FIGURE 10. KIWIPOINT-BY-POINT GROSS COUNT AND TRU ACTIVITY LEVELS. The data collected by the Kiwi system each second are presented with different colors corresponding to the different gross count and TRU activity levels. The TRU: ${ }^{24}{ }^{1} A m$ ratio is 16:1. Eachsquare represents anindividualmeasurement of the activity; the size of the square is about the width of the detector's footprint. 

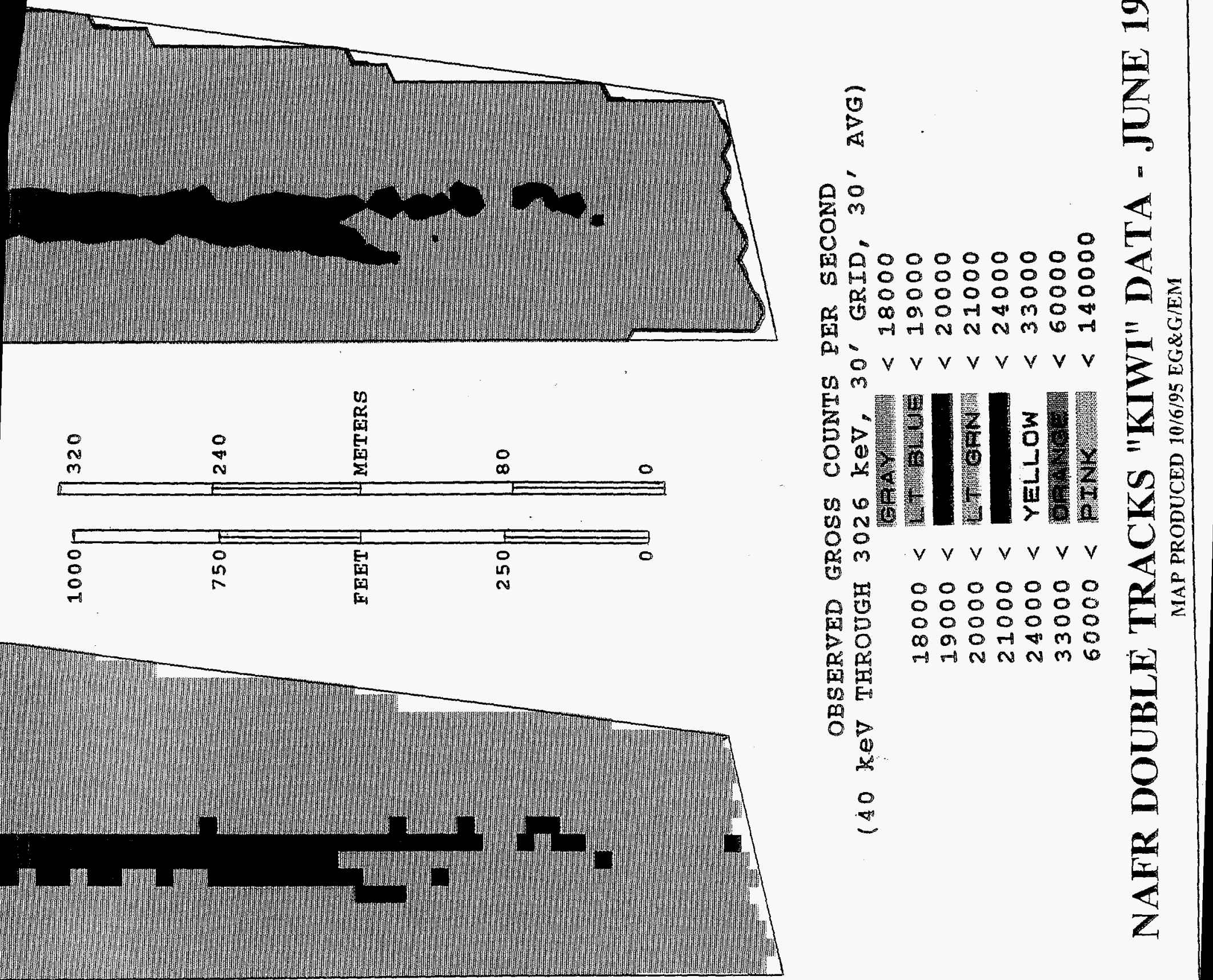


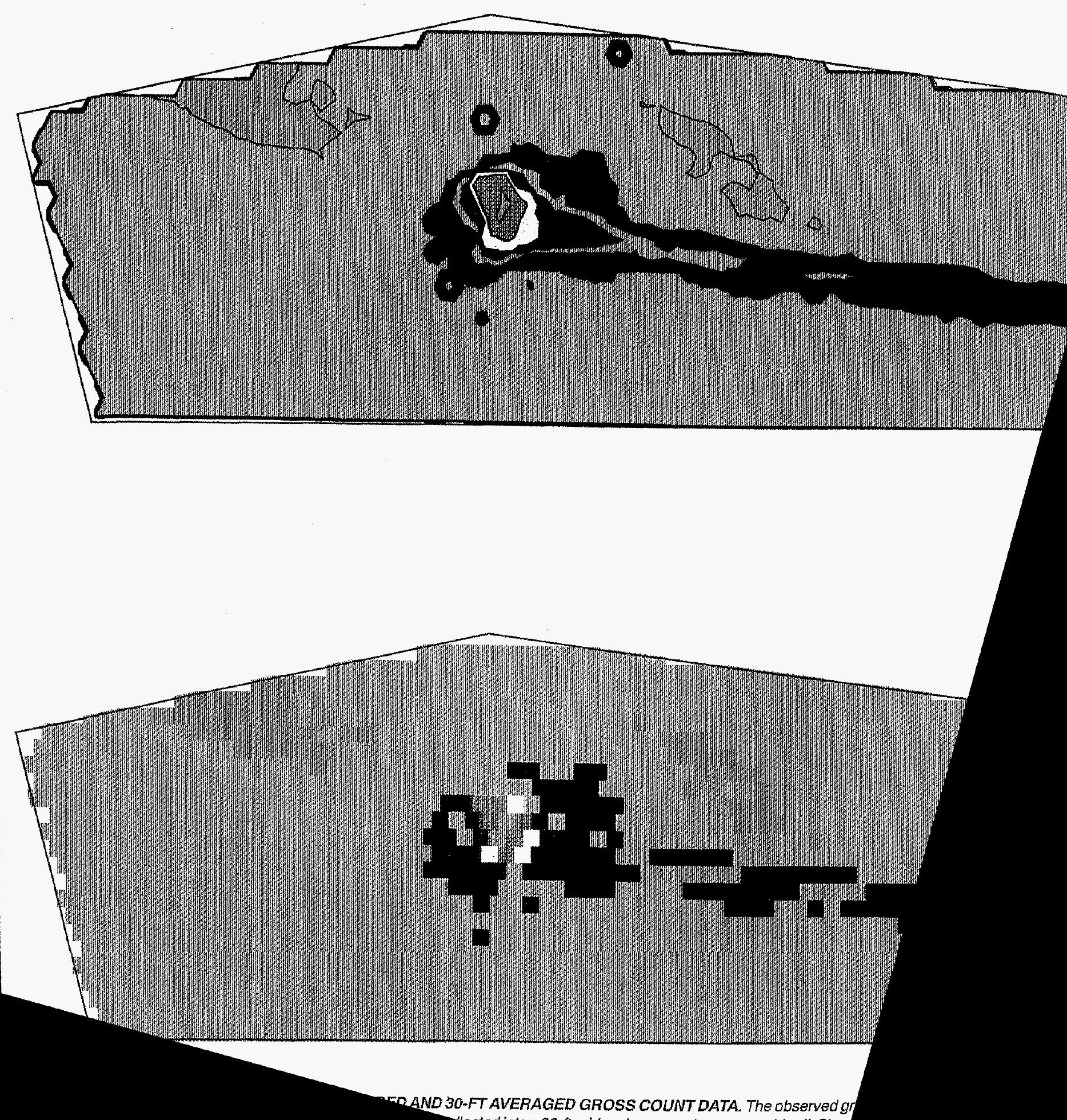



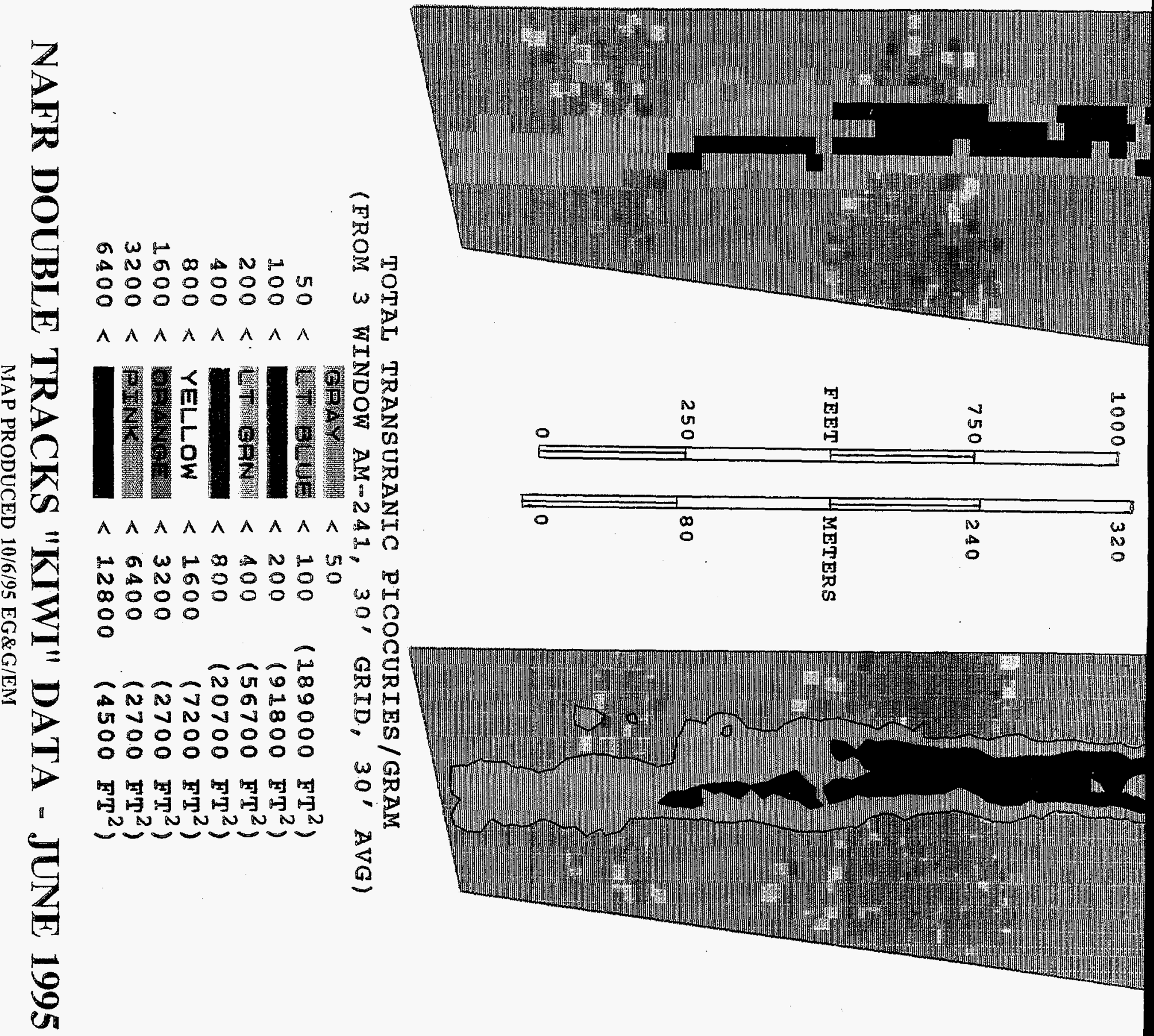

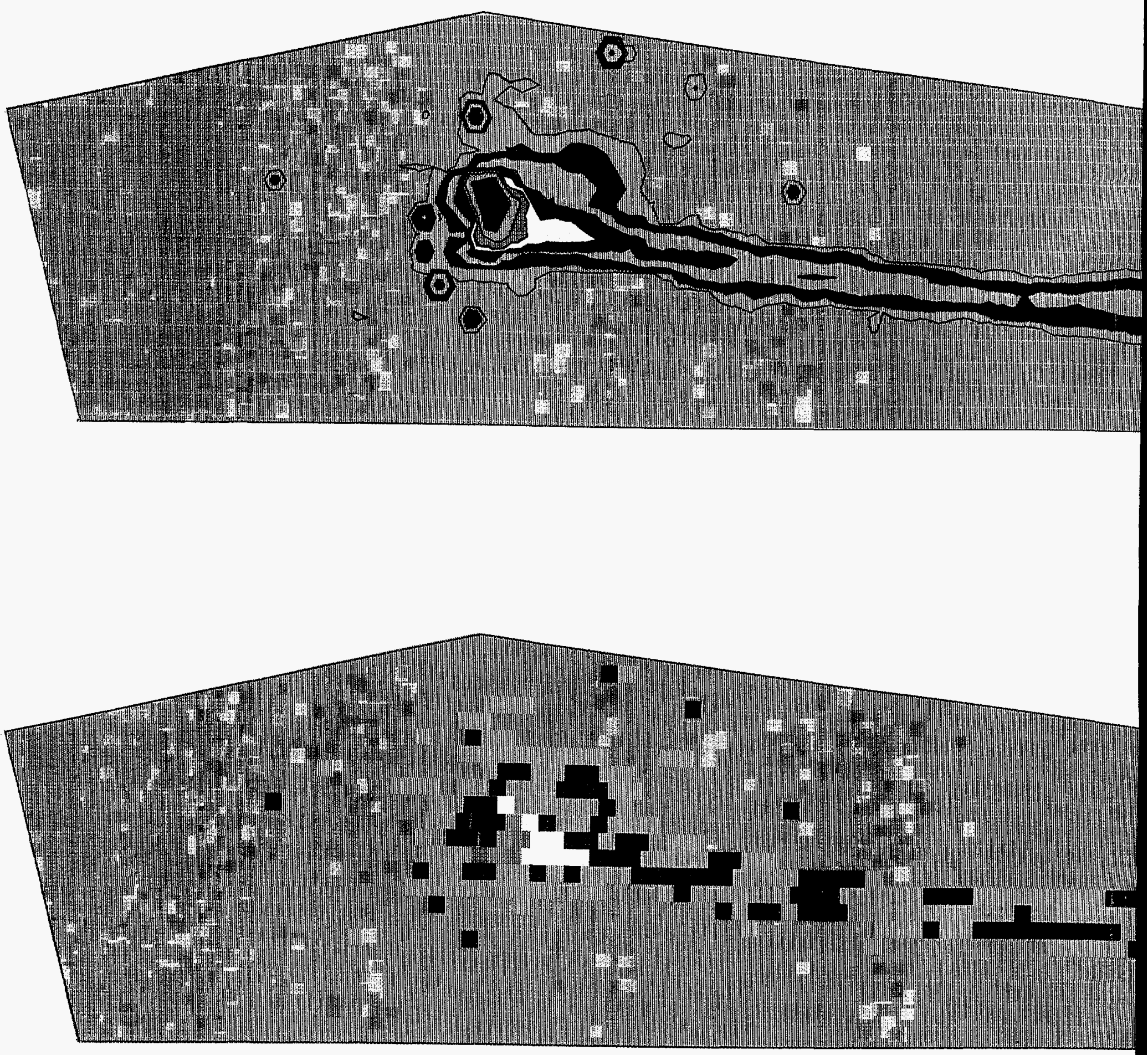

FIGURE 12. KIWI 30-FT GRIDDED AND 30-FT AVERAGED TRU ACTIVITIES. These plots are based on the same data presented in Figure 10 except that the ${ }^{241} \mathrm{Am}$ counts have been collected into $30-f t$ averages and centered on a 30 -ff grid. The data are presented both as squares centered on the grid loci and as contour levels derived from the gridded data. 

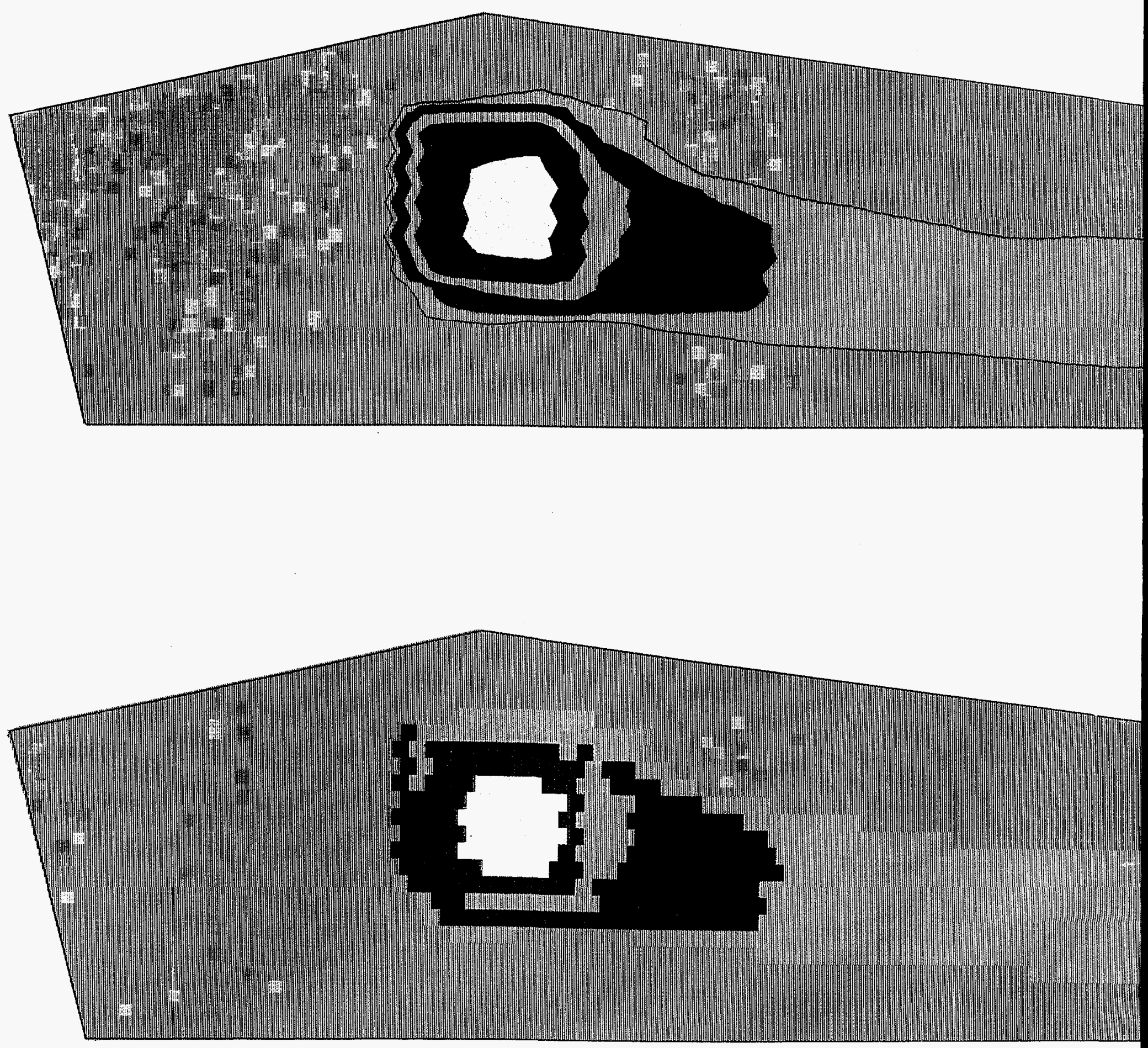

FIGURE 13. KIWI30-FT GRIDDED AND 270-FT AVERAGED TRU ACTIVITIES. These are the same data as in Figure 12, except that the ${ }^{241} \mathrm{~A}$ m counts have been collected into 270 -ft averages centered on a 30-ft grid. The 270-ft averages approximate the spatial resolution of the aerial system at $100 \mathrm{ft} \mathrm{AGL}$. The data are presented both as squares centered on the grid loci and as contour levels derived from the gridded data. Note how well the contour levels in the GZ area match those of Figure 2 in reference 6 (or the aerial data presented as part of Figure 5 in this document). 
east side. Actually, this maximum contour should be much larger and encompass most if not all of the mound, but the linear interpolation distorts the values in this area. On the plots, the fence is reconstructed from the measured GPS positions of the corner positions. The jagged boundary of the data is a consequence of collecting data only inside the fence. The data are presented both as colored squares corresponding to the level of activity at each grid location and as contour levels enclosing regions of the same or higher activity.

The preparation of the data in Figure 12 is similar to that of the previous figure, except that this plot is based on the count rate in the photopeak of the $60-\mathrm{keV}$ gamma rays from ${ }^{241} \mathrm{Am}$. The TRU activity shown in the figure uses the 16:1 TRU:241 Am ratio calculated earlier. Here there is a much better definition of the plume area as well as more details of hot spots within a few hundred feet of the GZ area. As discussed earlier, the Kiwi did not travel over the mound, and those grid cells were filled with a linear interpolation of the data measured around the base of the mound. Therefore, no specific conclusions should be drawn about the ${ }^{241} \mathrm{Am}$ or TRU activity from the Kiwi data on top of the mound. For these data, all grid points outside the fenced area were given ${ }^{241} \mathrm{Am}$ activities of zero. Even with this assumption, it is clear the plume extends all the way to and through the southern fence (see results of the Suburban measurements in Section 6.6).

If a second averaging scale of approximately $90 \mathrm{~m}$ $(270 \mathrm{ft})$ is used, the size of the grid footprint approaches the size of the aerial detector system footprint. Figure 13 shows the Kiwi TRU activity data using this new footprint. Notice the similarities in the contour shapes from the Kiwi data compared to the contour shapes from the aerial data in Figure 9 (recall that Figure 9 still uses the old TRU: ${ }^{241}$ Am ratio of $10: 1)$. There is quite good agreement around.GZ.

The Kiwi contours do not spread all the way to the eastern and western fences in the same way as the aerial data. This can be understood as a consequence of the aerial system not having a well-defined footprint. The Kiwi has Cd shielding on the sides of its detectors to limit detector visibility to the side. The aerial system has no shielding and the footprint is "defined" by the attenuation of the gamma rays traveling through the air to the detector. Thus a relatively weak source which is beyond the aerial system footprint can be ignored. However, a strong source (the mound) can contribute a few percent of its gamma rays to the aerial system even when it is well beyond the normal footprint limit, and therefore, it will produce an effect at large distances.

The agreement between the Kiwi and the aerial system is not quite as remarkable in the plume area. This may just be a result of the much lower activity and the aerial system's inability to do much with measurements made at or near its minimum detectable activity limit.

\subsection{Experiment \#6 (June)-HPGe In Situ Measurements}

In June, the Suburban HPGe detector system made a series of measurements to establish background levels around the outside of the fence at Double Tracks and at the revegetation site northeast of Double Tracks. The locations and activity levels measured by the Suburban system are listed in Table 6 . Figure 14 (see page 33) shows the locations marked by colored dots corresponding to the TRU activity. Again, the aerial and ground-based data in this figure both use a 16:1 ratio to convert the measured ${ }^{241} \mathrm{Am}$ activity to TRU activity.

As a check on the consistency of the data, the activity of a control point was measured at the beginning and end of each day. The results of these measurements are listed in Table 7 (see page 34). Once the Suburban went inside the exclusion zone, it stayed there until the end of the week. Thus two separate control points were established: one outside, which was used on the first day, and one inside, which was used on the remaining days. The two dots in Figure 14 identify the two control points. The ${ }^{241} \mathrm{Am}$ activity at the control points is very low (below the minimum detectable activity) and counting statistics dominate. The daily comparisons were made using the ${ }^{40} \mathrm{~K}$ photopeak at $1,461 \mathrm{keV}$ and the ${ }^{228} \mathrm{Ac}$ pair of photopeaks around $965 \mathrm{keV}$, which had sufficient counts in the 600 -second measurements.

These control points also provided a check on the variations in the GPS positioning system. One second of latitude is approximately $31 \mathrm{~m}$ (101 ft) while one second of longitude is only about $24 \mathrm{~m}$ (80 ft). While the Suburban was returned daily to what visually appeared to be the same location, the variation appears to follow the 3-5 $\mathrm{m}(10-15 \mathrm{ft})$ accuracy of this particular GPS system. 
Table 6. Suburban Measurements in June. The locations and Am concentrations are shown for the HPGe measurements made at the Double Tracks area. Excluded from the table are the energy calibration measurements. The TRU concentration is based on a $\left({ }^{239} \mathrm{Pu}+{ }^{240} \mathrm{Pu}+{ }^{241} \mathrm{Am}\right):{ }^{241} \mathrm{Am}$ ratio of 16 . Positions shown in italics never received a lock on the differential GPS signal, so they have a positional uncertainty on the order of $100 \mathrm{~m}$ (300 ft).

\begin{tabular}{|c|c|c|c|c|c|c|}
\hline $\begin{array}{l}\text { File } \\
\text { No. }\end{array}$ & Latitude (N) & Longitude (W) & \multicolumn{2}{|c|}{$\begin{array}{l}241 \mathrm{Am} \\
(\mathrm{pCl} / \mathrm{g})\end{array}$} & \multicolumn{2}{|c|}{$\begin{array}{c}\text { TRU } \\
(\mathrm{pCl} / \mathrm{g})\end{array}$} \\
\hline 3 & $37^{\circ} 42^{\prime} 14.27^{\prime \prime}$ & $116^{\circ} 59^{\prime} 14.87^{\prime \prime}$ & \multicolumn{2}{|c|}{$<\mathrm{MDA}^{\mathrm{a}}$} & \multicolumn{2}{|c|}{$<\mathrm{MDA}^{\mathrm{a}}$} \\
\hline 4 & $37^{\circ} 41^{\prime} 58.25^{\prime \prime}$ & $116^{\circ} 59^{\prime} 18.54^{\prime \prime}$ & \multicolumn{2}{|c|}{$<\mathrm{MDA}^{\mathrm{a}}$} & \multicolumn{2}{|c|}{$<\mathrm{MDA}^{\mathrm{a}}$} \\
\hline 5 & $37^{\circ} 41^{\prime} 57.61^{\prime \prime}$ & $116^{\circ} 59^{\prime} 23.62^{\prime \prime}$ & \multicolumn{2}{|c|}{$<\mathrm{MDA}^{\mathrm{a}}$} & \multicolumn{2}{|c|}{$<\mathrm{MDA}^{\mathrm{a}}$} \\
\hline 6 & $37^{\circ} 42^{\prime} 17.50^{\prime \prime}$ & $116^{\circ} 59^{\prime} 22.65^{\prime \prime}$ & \multicolumn{2}{|c|}{$<\mathrm{MDA}^{\mathrm{a}}$} & \multicolumn{2}{|c|}{$<\mathrm{MDA}^{\mathrm{a}}$} \\
\hline 7 & $37^{\circ} 42^{\prime} 29.20^{\prime \prime}$ & $116^{\circ} 59^{\prime} 21.83^{\prime \prime}$ & \multicolumn{2}{|c|}{$<$ MDA $^{a}$} & \multicolumn{2}{|c|}{$<\mathrm{MDA}^{\mathrm{a}}$} \\
\hline 8 & $37^{\circ} 42^{\prime} 30.59^{\prime \prime}$ & $116^{\circ} 59^{\prime} 14.97^{\prime \prime}$ & \multicolumn{2}{|c|}{$<\mathrm{MDA}^{\mathrm{a}}$} & \multicolumn{2}{|c|}{$<M^{a} A^{a}$} \\
\hline 9 & $37^{\circ} 42^{\prime} 34.29^{\prime \prime}$ & $116^{\circ} 59^{\prime} 0.66^{\prime \prime}$ & \multicolumn{2}{|c|}{$<\mathrm{MDA}^{\mathrm{a}}$} & \multicolumn{2}{|c|}{$<\mathrm{MDA}^{\mathrm{a}}$} \\
\hline 10 & $37^{\circ} 41^{\prime} 57.89^{\prime \prime}$ & $116^{\circ} 59^{\prime} 21.10^{\prime \prime}$ & 9.37 & \pm 0.58 & 149.9 & \pm 9.3 \\
\hline 11 & $37^{\circ} 41^{\prime} 53.04^{\prime \prime}$ & $116^{\circ} 59^{\prime} 21.30^{\prime \prime}$ & 5.69 & \pm 0.56 & 91.0 & \pm 9.0 \\
\hline 13 & $37^{\circ} 41^{\prime} 58.12^{\prime \prime}$ & $116^{\circ} 59^{\prime} 21.44^{\prime \prime}$ & 7.49 & \pm 0.56 & 119.8 & \pm 9.0 \\
\hline 14 & $37^{\circ} 42^{\prime} 1.19^{\prime \prime}$ & $116^{\circ} 59^{\prime} 21.74^{\prime \prime}$ & 6.05 & \pm 0.55 & 96.8 & \pm 8.8 \\
\hline 15 & $37^{\circ} 42^{\prime} 4.28^{\prime \prime}$ & $116^{\circ} 59^{\prime} 21.13^{\prime \prime}$ & 9.70 & \pm 0.59 & 155.2 & \pm 9.4 \\
\hline 16 & $37^{\circ} 42^{\prime} 7.09^{\prime \prime}$ & $116^{\circ} 59^{\prime} 20.11^{\prime \prime}$ & 14.10 & \pm 0.62 & 225.6 & \pm 9.9 \\
\hline 23 & $37^{\circ} 42^{\prime} 7.24^{\prime \prime}$ & $116^{\circ} 59^{\prime} 20.38^{\prime \prime}$ & 19.19 & \pm 0.66 & 307.0 & \pm 10.6 \\
\hline 24 & $37^{\circ} 42^{\prime} 10.09^{\prime \prime}$ & $116^{\circ} 59^{\prime} 20.00^{\prime \prime}$ & 30.70 & \pm 0.73 & 491.2 & \pm 11.7 \\
\hline 25 & $37^{\circ} 42^{\prime} 13.15^{\prime \prime}$ & $116^{\circ} 59^{\prime} 20.14^{\prime \prime}$ & 17.32 & \pm 0.65 & 277.1 & \pm 10.4 \\
\hline 26 & $37^{\circ} 42^{\prime} 14.84^{\prime \prime}$ & $116^{\circ} 59^{\prime} 19.75^{\prime \prime}$ & 22.22 & \pm 0.70 & 355.5 & \pm 11.2 \\
\hline 27 & $37^{\circ} 42^{\prime} 17.09^{\prime \prime}$ & $116^{\circ} 59^{\prime} 19.38^{\prime \prime}$ & 15.63 & \pm 0.65 & 250.1 & \pm 10.4 \\
\hline 28 & $37^{\circ} 42^{\prime} 18.12^{\prime \prime}$ & $116^{\circ} 59^{\prime} 19.41^{\prime \prime}$ & 6.70 & \pm 0.57 & 107.2 & \pm 9.1 \\
\hline 29 & $37^{\circ} 42^{\prime} 19.16^{\prime \prime}$ & $116^{\circ} 59^{\prime} 19.14^{\prime \prime}$ & 11.57 & \pm 0.62 & 185.1 & \pm 9.9 \\
\hline 30 & $37^{\circ} 42^{\prime} 19.40^{\prime \prime}$ & $116^{\circ} 59^{\prime} 18.82^{\prime \prime}$ & 19.54 & \pm 0.67 & 312.6 & \pm 10.7 \\
\hline 31 & $37^{\circ} 42^{\prime} 19.92^{\prime \prime}$ & $116^{\circ} 59^{\prime} 18.73^{\prime \prime}$ & 28.34 & \pm 0.74 & 453.4 & \pm 11.8 \\
\hline 32 & $37^{\circ} 42^{\prime} 20.42^{\prime \prime}$ & $116^{\circ} 59^{\prime} 18.47^{\prime \prime}$ & 52.36 & \pm 0.90 & 837.8 & \pm 14.4 \\
\hline 33 & $37^{\circ} 42^{\prime} 20.90^{\prime \prime}$ & $116^{\circ} 59^{\prime} 18.24^{\prime \prime}$ & 86.12 & \pm 1.06 & $1,377.9$ & \pm 17.0 \\
\hline 34 & $37^{\circ} 42^{\prime} 23.04^{\prime \prime \prime}$ & $116^{\circ} 59^{\prime} 17.45^{\prime \prime}$ & 13.69 & \pm 0.63 & 219.0 & \pm 10.1 \\
\hline 35 & $37^{\circ} 42^{\prime} 23.78^{\prime \prime}$ & $116^{\circ} 59^{\prime} 17.21^{\prime \prime}$ & 3.02 & \pm 0.52 & 48.3 & \pm .9 .3 \\
\hline 43 & $37^{\circ} 42^{\prime} 24.89^{\prime \prime}$ & $116^{\circ} 59^{\prime} 16.72^{\prime \prime}$ & 2.77 & \pm 0.53 & 44.3 & \pm 8.5 \\
\hline 44 & $37^{\circ} 42^{\prime} 26.53^{\prime \prime}$ & $116^{\circ} 59^{\prime} 16.09^{\prime \prime}$ & \multicolumn{2}{|c|}{$<\mathrm{MDA}^{\mathrm{a}}$} & \multicolumn{2}{|c|}{$<\mathrm{MDA}^{\mathrm{a}}$} \\
\hline 45 & $37^{\circ} 42^{\prime} 29.33^{\prime \prime}$ & $116^{\circ} 59^{\prime} 15.10^{\prime \prime}$ & \multicolumn{2}{|c|}{$<\mathrm{MDA}^{\mathrm{a}}$} & \multicolumn{2}{|c|}{$<\mathrm{MDA}^{\mathrm{a}}$} \\
\hline 46 & $37^{\circ} 42^{\prime} 22.82^{\prime \prime}$ & $116^{\circ} 59^{\prime} 22.16^{\prime \prime}$ & 1.75 & \pm 0.51 & 28.0 & \pm 8.2 \\
\hline 47 & $37^{\circ} 42^{\prime} 22.74^{\prime \prime}$ & $116^{\circ} 59^{\prime} 20.81^{\prime \prime}$ & 2.15 & \pm 0.53 & 34.4 & \pm 8.5 \\
\hline 48 & $37^{\circ} 42^{\prime} 22.50^{\prime \prime}$ & $116^{\circ} 59^{\prime} 19.50^{\prime \prime}$ & 2.46 & \pm 0.53 & 39.4 & \pm 8.5 \\
\hline 49 & $37^{\circ} 42^{\prime} 22.28^{\prime \prime}$ & $116^{\circ} 59^{\prime} 18.98^{\prime \prime}$ & 7.38 & \pm 0.58 & 118.1 & \pm 9.3 \\
\hline 50 & $37^{\circ} 42^{\prime} 21.59^{\prime \prime}$ & $116^{\circ} 59^{\prime} 16.55^{\prime \prime}$ & 75.50 & \pm 1.04 & $1,208.0$ & \pm 16.6 \\
\hline 51 & $37^{\circ} 42^{\prime} 21.42^{\prime \prime}$ & $116^{\circ} 59^{\prime} 16.17^{\prime \prime}$ & 11.72 & \pm 0.61 & 187.5 & \pm 9.8 \\
\hline
\end{tabular}

a The Minimum Detectable Activity (MDA) is equal to $3 \sigma$ where $\sigma$ is the standard deviation of the counting statistics. For measurements made at a height of $3 \mathrm{~m}$, the MDA is $1.0 \mathrm{pCi} / \mathrm{g}$ of ${ }^{241} \mathrm{Am}$ and $16.0 \mathrm{pCi} / \mathrm{g}$ of TRU. For measurements made at a height of $7.5 \mathrm{~m}$, the MDA is $1.5 \mathrm{pCi} / \mathrm{g}$ of ${ }^{241} \mathrm{Am}$ and $24.0 \mathrm{pCi} / \mathrm{g}$ of TRU. 
Table 6. Suburban Measurements in June (continued)

\begin{tabular}{|c|c|c|c|c|c|c|}
\hline \multirow{2}{*}{$\begin{array}{l}\text { File } \\
\text { No. } \\
52\end{array}$} & \multirow{2}{*}{$\begin{array}{l}\text { Latitude (N) } \\
37^{\circ} 42^{\prime} 21.19^{\prime \prime}\end{array}$} & \multirow{2}{*}{$\frac{\text { Longitude (W) }}{116^{\circ} 59^{\prime} 15.42^{\prime \prime}}$} & \multicolumn{2}{|c|}{$\begin{array}{l}241 \mathrm{Am} \\
(\mathrm{pCi} / \mathrm{g})\end{array}$} & \multicolumn{2}{|c|}{$\begin{array}{c}\text { TRU } \\
(\mathrm{pCi} / \mathrm{g})\end{array}$} \\
\hline & & & 6.15 & \pm 0.57 & 98.4 & \pm 9.1 \\
\hline 53 & $37^{\circ} 42^{\prime} 21.24^{\prime \prime}$ & $116^{\circ} 59^{\prime} 14.92^{\prime \prime}$ & 7.57 & \pm 0.57 & 121.1 & \pm 9.1 \\
\hline 54 & $37^{\circ} 42^{\prime} 20.91^{\prime \prime}$ & $116^{\circ} 59^{\prime} 14.25^{\prime \prime}$ & 4.58 & \pm 0.53 & 73.3 & \pm 8.5 \\
\hline 55 & $37^{\circ} 42^{\prime} 20.72^{\prime \prime}$ & $116^{\circ} 59^{\prime} 13.51^{\prime \prime}$ & \multicolumn{2}{|c|}{$<$ MDA $^{\mathrm{a}}$} & \multicolumn{2}{|c|}{$<\mathrm{MDA}^{\mathrm{a}}$} \\
\hline 56 & $37^{\circ} 42^{\prime} 21.10^{\prime \prime}$ & $116^{\circ} 59^{\prime} 17.20^{\prime \prime}$ & 19.43 & \pm 0.67 & 310.9 & \pm 10.7 \\
\hline 57 & $37^{\circ} 42^{\prime} 20.34^{\prime \prime}$ & $116^{\circ} 59^{\prime} 17.35^{\prime \prime}$ & 46.25 & \pm 0.85 & 740.0 & \pm 13.6 \\
\hline 58 & $37^{\circ} 42^{\prime} 20.60^{\prime \prime}$ & $116^{\circ} 59^{\prime} 19.00^{\prime \prime}$ & 2.57 & \pm 0.55 & 41.1 & \pm 8.8 \\
\hline 59 & $37^{\circ} 42^{\prime} 21.63^{\prime \prime}$ & $116^{\circ} 59^{\prime} 19.69^{\prime \prime}$ & 1.86 & \pm 0.52 & 29.8 & \pm 8.3 \\
\hline 60 & $37^{\circ} 42^{\prime} 20.61^{\prime \prime}$ & $116^{\circ} 59^{\prime} 19.58^{\prime \prime}$ & \multicolumn{2}{|c|}{$<\mathrm{MDA}^{\mathrm{a}}$} & \multicolumn{2}{|c|}{$<\mathrm{MDA}^{\mathrm{a}}$} \\
\hline 61 & $37^{\circ} 42^{\prime} 19.82^{\prime \prime}$ & $116^{\circ} 59^{\prime} 17.24^{\prime \prime}$ & 17.50 & \pm 0.66 & 280.0 & \pm 10.6 \\
\hline 73 & $37^{\circ} 42^{\prime} 20.04^{\prime \prime}$ & $116^{\circ} 59^{\prime} 15.51^{\prime \prime}$ & 4.76 & \pm 0.55 & 76.2 & \pm 8.8 \\
\hline 74 & $37^{\circ} 42^{\prime} 18.02^{\prime \prime}$ & $116^{\circ} 59^{\prime} 16.84^{\prime \prime}$ & 3.54 & \pm 0.55 & 56.6 & \pm 8.8 \\
\hline 75 & $37^{\circ} 42^{\prime} 16.67^{\prime \prime}$ & $116^{\circ} 59^{\prime} 16.24^{\prime \prime}$ & 1.78 & \pm 0.51 & 28.5 & \pm 8.2 \\
\hline
\end{tabular}

a The Minimum Detectable Activity (MDA) is equal to $3 \sigma$ where $\sigma$ is the standard deviation of the counting statistics. For measurements made at a height of $3 \mathrm{~m}$, the MDA is $1.0 \mathrm{pCi} / \mathrm{g}$ of ${ }^{241} \mathrm{Am}$ and $16.0 \mathrm{pCi} / \mathrm{g}$ of TRU. For measurements made at a height of $7.5 \mathrm{~m}$, the MDA is $1.5 \mathrm{pCi} / \mathrm{g}$ of ${ }^{241} \mathrm{Am}$ and $24.0 \mathrm{pCi} / \mathrm{g}$ of TRU.

\subsection{Experiment \#7 (June)-Hot-Piece Activity Measurements}

Results of the metallic piece measurements are given in Table 8 (see page 35). Most pieces were relatively flat and approximately 0.5 to $1.0 \mathrm{~cm}(0.2-0.4$ in) thick. Assuming that the pieces were thick enough to stop the ${ }^{241} \mathrm{Am} 60-\mathrm{keV}$ gamma ray, the total activity contained on a piece is the sum of that obtained from measuring each side. By dividing this total by the mass of the piece, the activity per unit mass can be determined. These results, for both ${ }^{241} \mathrm{Am}$ and TRU, are also presented in Table 8. As shown in this table, all these pieces greatly exceed the level $(0.1 \mu \mathrm{Ci} / \mathrm{g})$ currently used to separate TRU waste from low-level waste.

Table 9 (see page 36) presents the results of the soil sample measurements. The lower density of the soil (compared to the metallic pieces discussed above) and the size of the bottles allow some fraction of the ${ }^{241} \mathrm{Am} 60-\mathrm{keV}$ gamma rays to escape through either side of the bottle. Thus a measurement of both sides may count the activity of a location in the bottle twice. The TRU values given in the table are based on the sum of the activity measured from each side. The actual total soil activity should be somewhere between the value obtained from one side and the sum of the activity measured from both sides. The data show that some very small areas within the inner fence have activity levels slightly greater than that used to define TRU waste. However, the areas involved are quite small compared to the total area that will have soil removed during the remediation. Most of the soil to be removed has activity levels well below the TRU level. Therefore, the bulk soil transported off-site for disposal should fall well within the classification used for low-level waste.

\subsection{SUMMARY}

A series of measurements were conducted at the Double Tracks site on Stonewall Flat at the NAFR. The April expedition tested a number of new techniques and performed several preliminary characterization measurements. In addition, three techniques for rapidly assessing the Am and $\mathrm{Pu}$ depth profiles were tested. Several plots comparing these groundbased system measurements with each other and with the 1993 aerial data show remarkable agreement.

The June expedition focused on the site characterization using the newly designed Kiwi vehicle. Another new detector platform, an ATV equipped with FIDLER detectors, performed a search for hot pieces marking the locations for later removal by teams of "miners." 

DOUBLE TRACKS Site

June Suburban HPGe Data

\begin{tabular}{|l|c|}
\hline COLOR & TRU (pCi/g) \\
\hline Black & $<50$ \\
\hline Blus & $50-100$ \\
\hline Green & $100-200$ \\
\hline Yeilow & $200-600$ \\
\hline Red & $>600$ \\
\hline Ground-based data from Suburban \\
HPGe system taken at 7.5-meter \\
heights. \\
Conversion assumptions include: \\
characterized detector \\
3-cm relaxation length \\
$2.5-c m$ sample depth \\
TRU: Am ratio = t6
\end{tabular}
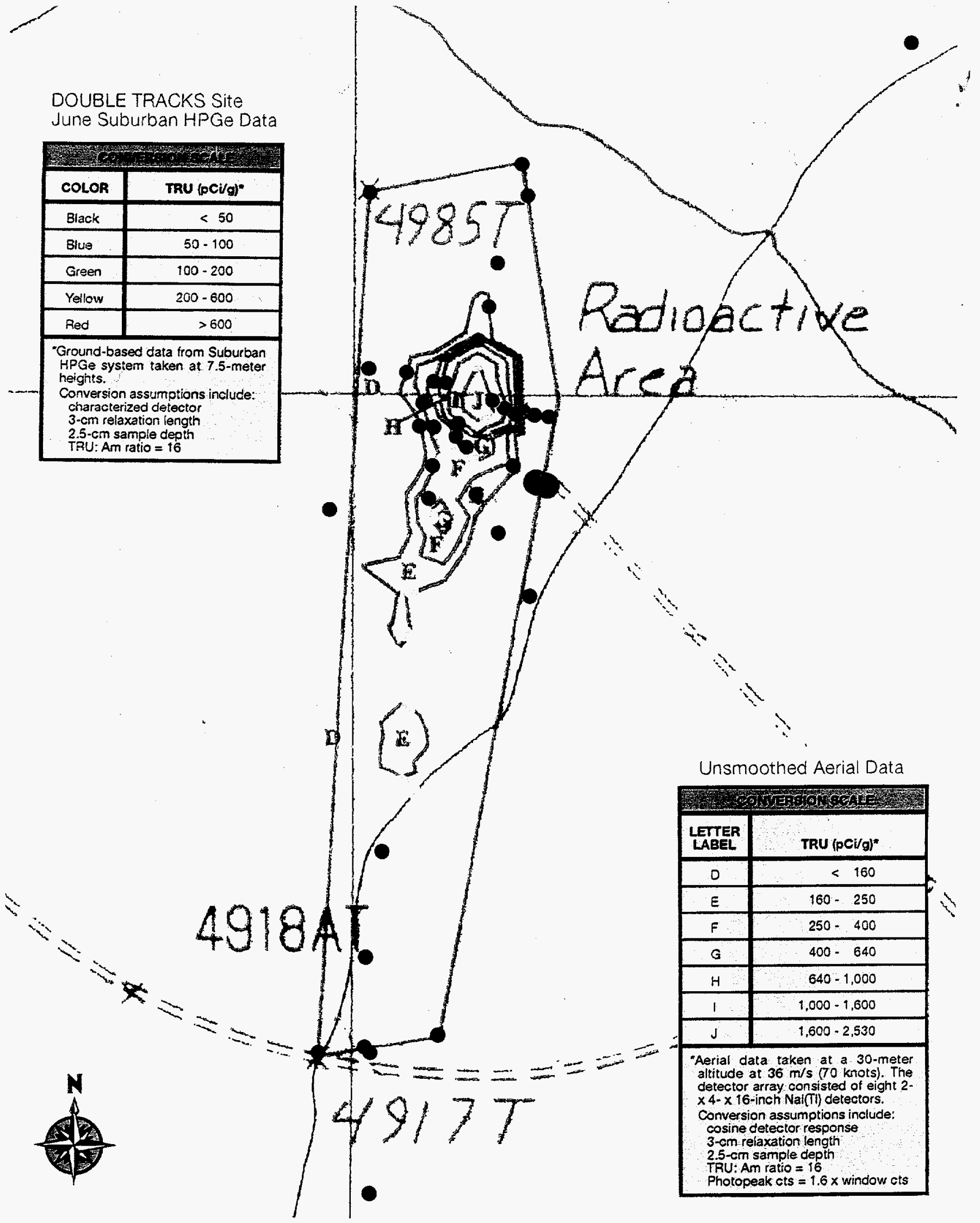

FIGURE 14. MEASUREMENT LOCATIONS OFTHE SUBURBANSYSTEM (JUNE). The locations (by GPS coordinates) of the SUbUrban measurements are marked by colored dots corresponding to five bands of TRU activity. The contour data from the 1993 aerial survey are included for reference. Both sets of data use the 16:1 TRU: ${ }^{241}$ Am activity ratio. The two control points (one inside the fence and one outside) are indicated by the large dots. 

Both of these new systems performed better than expected.

For future site characterizations, the ATV will search for hot pieces. The tripod HPGe systems will obtain rough depth distributions in the soil and measure isotopic ratios. The Suburban system with the HPGe detector suspended on the end of a mast will make spot measurements inside the contaminated area as well as a set of measurements to establish background radiation levels. Once all of this work is compiete and these systems leave the area, the Kiwi system will perform the actual characterization measurements of the site. The Kiwi will use the depth distributions and isotopic ratios to calculate accurate soil concentration and the horizontal distribution of the contamination.

Table 7. Control Point Suburban Measurements in June. The locations and isotopic concentrations are shown for the HPGe measurements made at the daily control points. Positions shown in italics never received a lock on the differential GPS signal, so they have a positional uncertainty on the order of $100 \mathrm{~m}$ (300 ft).

\begin{tabular}{|c|c|c|c|c|c|c|}
\hline $\begin{array}{l}\text { File } \\
\text { No. }\end{array}$ & \multirow{2}{*}{ Latitude (N) } & \multirow[t]{2}{*}{ Longitude (W) } & \multicolumn{2}{|c|}{$\begin{array}{l}{ }^{228} \mathrm{Ac} \\
(\mathrm{pCi} / \mathrm{g})\end{array}$} & \multicolumn{2}{|c|}{$\begin{array}{c}40 \mathrm{~K} \\
(\mathrm{pCi} / \mathrm{g})\end{array}$} \\
\hline \multicolumn{5}{|c|}{ Outside Fence } & & \\
\hline 2 & $37^{\circ} 42^{\prime} 18.55^{\prime \prime}$ & $116^{\circ} 59^{\prime} 13.48^{\prime \prime}$ & \multicolumn{4}{|c|}{ not recorded } \\
\hline 12 & $37^{\circ} 42^{\prime} 18.44^{\prime \prime}$ & $116^{\circ} 59^{\prime} 13.54^{\prime \prime}$ & 3.38 & \pm 0.24 & 63.5 & \pm 1.3 \\
\hline \multicolumn{7}{|c|}{ Inside Fence } \\
\hline 22 & $37^{\circ} 42^{\prime} 19.25^{\prime \prime}$ & $116^{\circ} 59^{\prime} 14.00^{\prime \prime}$ & \multicolumn{4}{|c|}{ not.recorded } \\
\hline 36 & $37^{\circ} 42^{\prime} 18.91^{\prime \prime}$ & $116^{\circ} 59^{\prime} 14.25^{\prime \prime}$ & 2.92 & \pm 0.22 & 57.2 & \pm 1.3 \\
\hline 42 & $37^{\circ} 42^{\prime} 20.34^{\prime \prime}$ & $116^{\circ} 59^{\prime} 14.99^{\prime \prime}$ & 3.15 & \pm 0.23 & 60.5 & \pm 1.3 \\
\hline 62 & $37^{\circ} 42^{\prime} 18.94^{\prime \prime}$ & $116^{\circ} 59^{\prime} 14.06^{\prime \prime}$ & 2.71 & \pm 0.24 & 57.6 & \pm 1.3 \\
\hline 72 & $37^{\circ} 42^{\prime} 18.70^{\prime \prime}$ & $116^{\circ} 59^{\prime} 14.06^{\prime \prime}$ & 3.33 & \pm 0.23 & 58.8 & \pm 1.2 \\
\hline 76 & $37^{\circ} 42^{\prime} 18.67^{\prime \prime}$ & $116^{\circ} 59^{\prime} 14.15^{\prime \prime}$ & 3.00 & \pm 0.23 & 57.7 & \pm 1.3 \\
\hline
\end{tabular}


Table 8. "Pieces" Activity Measurements from June. Selected pieces of metal, coated with an Am and Pu mixture, were collected and measured during the June survey. Their specific activity measurements place them in the TRU waste category. Note that the activities in this table are $\mu \mathrm{Ci} / \mathrm{g}$ rather than the $\mathrm{pCi} / \mathrm{g}$ used throughout the rest of the report.

\begin{tabular}{|c|c|c|c|c|c|c|}
\hline \multirow[b]{2}{*}{$\begin{array}{l}\text { Piece } \\
\text { Number }\end{array}$} & \multicolumn{3}{|c|}{${ }^{241}$ Am Activity } & \multirow[b]{2}{*}{$\begin{array}{c}\text { Mass } \\
(g)\end{array}$} & \multirow{2}{*}{$\begin{array}{c}241 \text { Am } \\
\text { Act./mass } \\
(\mu \mathrm{Ci} / \mathrm{g})\end{array}$} & \multirow{2}{*}{$\begin{array}{c}\text { Trua } \\
\text { Act./mass } \\
(\mu \mathrm{Ci} / \mathrm{g})\end{array}$} \\
\hline & $\begin{array}{c}\text { Side } 1 \\
(\mu \mathrm{Ci})\end{array}$ & $\begin{array}{c}\text { Side } 2 \\
(\mu \mathrm{Ci})\end{array}$ & $\begin{array}{l}\text { Total } \\
(\mu \mathrm{Ci})\end{array}$ & & & \\
\hline \multicolumn{7}{|l|}{$06 / 07 / 95^{b}$} \\
\hline 1 & 143.7 & 179.5 & 323.2 & 33.25 & 9.7 & 155 \\
\hline 2 & 71.4 & 89.0 & 160.4 & 30.68 & 5.2 & 84 \\
\hline 3 & 357.1 & 255.5 & 612.6 & 254.01 & 2.4 & 39 \\
\hline 4 & 318.3 & 366.1 & 684.4 & 316.4 & 2.2 & 35 \\
\hline - 5 & 167.0 & 144.5 & 311.5 & 124.12 & 2.5 & 40 \\
\hline 6 & 157.8 & 211.3 & 369.1 & 58.87 & 6.3 & 100 \\
\hline 7 & 54.2 & 54.2 & 108.4 & 13.41 & 8.1 & 130 \\
\hline 10 & 106.2 & 120.4 & 226.6 & 95.55 & 2.4 & 38 \\
\hline 11 & 17.7 & 17.6 & 35.3 & 21.33 & 1.7 & 27 \\
\hline 12 & 49.6 & 54.8 & 104.4 & 2.4 & 43.5 & 696 \\
\hline \multicolumn{7}{|l|}{$06 / 08 / 95^{c}$} \\
\hline 13 & 87.7 & 74.3 & 162.0 & 107.36 & 1.5 & 24 \\
\hline 14 & 123.3 & 123.3 & 246.6 & 39.78 & 6.2 & 99 \\
\hline 15 & 38.5 & 47.7 & 86.2 & 17.38 & 5.0 & 80 \\
\hline
\end{tabular}

a Assumed a TRU to ${ }^{241} \mathrm{Am}$ ratio of 16. Note: TRU waste is defined as an activity/mass greater than $0.1 \mu \mathrm{Ci} / \mathrm{g}$.

bubtracted a background activity of $5.4 \mu \mathrm{Ci}$.

c Subtracted a background activity of $1.3 \mu \mathrm{Ci}$. 
Table 9. Soil Sample Activity Measurements from June. Selected soil samples measured during the June expedition exhibit Am and TRU activity levels higher than the definition of TRU waste. For soil sample counting, the actual value will probably be closer to that obtained from one side only, which would be approximately half the value quoted here. Note that the activities in this table are $\mu \mathrm{Ci} / \mathrm{g}$ rather than the $\mathrm{pCi} / \mathrm{g}$ used throughout the rest of the report.

\begin{tabular}{|c|c|c|c|c|c|c|}
\hline \multirow[b]{2}{*}{$\begin{array}{l}\text { Sample } \\
\text { Number }\end{array}$} & \multicolumn{3}{|c|}{${ }^{241}$ Am Activity } & \multirow[b]{2}{*}{$\begin{array}{c}\text { Mass } \\
\text { (g) }\end{array}$} & \multirow{2}{*}{$\begin{array}{c}241 \text { Am } \\
\text { Act./mass } \\
(\mu \mathrm{Ci} / \mathrm{g})\end{array}$} & \multirow{2}{*}{$\begin{array}{c}\text { TRUa } \\
\text { Act./mass } \\
(\mu \mathrm{Cl} / \mathrm{g})\end{array}$} \\
\hline & $\begin{array}{c}\text { Side } 1 \\
(\mu \mathrm{Ci})\end{array}$ & $\begin{array}{c}\text { Side } 2 \\
(\mu \mathrm{Ci})\end{array}$ & $\begin{array}{l}\text { Total } \\
(\mu \mathrm{Ci})\end{array}$ & & & \\
\hline \multicolumn{7}{|l|}{$06 / 07 / 95^{b}$} \\
\hline 8 & 2.5 & 3.8 & 6.3 & 796.62 & 0.008 & 0.128 \\
\hline 9 & 8.2 & 6.0 & 14.2 & 746.97 & 0.019 & 0.304 \\
\hline \multicolumn{7}{|l|}{ 06/08/95c } \\
\hline$S 1^{d}$ & 2.3 & 2.4 & 4.7 & 558.41 & 0.008 & 0.134 \\
\hline $\mathrm{S} 2^{\mathrm{e}}$ & 5.9 & 6.3 & 12.2 & 240.87 & 0.051 & 0.816 \\
\hline $53^{f}$ & 4.6 & 5.0 & 9.6 & 297.77 & 0.032 & 0.512 \\
\hline$S 49$ & 5.8 & 5.7 & 11.5 & 345.86 & 0.033 & 0.528 \\
\hline
\end{tabular}

a Assumed a TRU to ${ }^{241} \mathrm{Am}$ ratio of 16 . Note: TRU waste is defined as an activity/mass greater than $0.1 \mu \mathrm{Ci} / \mathrm{g}$.

b Subtracted a background activity of $5.4 \mu \mathrm{Ci}$. Samples were taken from soil previously collected from areas within the exclusion area which were identified by the FIDLER detectors on the ATV as containing elevated amounts of Am.

c Subtracted a background activity of $1.3 \mu \mathrm{Ci}$.

¿Sample was collected approximately $20 \mathrm{~m}$ ( $60 \mathrm{ft}$ ) from $\mathrm{GZ}$ in direction of $65^{\circ}$.

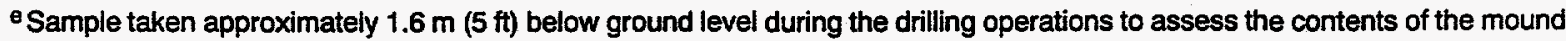
at GZ.

f Sample taken approximately $30 \mathrm{~m}(100 \mathrm{ft})$ east of GZ.

g Sample taken approximately $45 \mathrm{~m}$ (150 ft) east of GZ. 


\section{APPENDIX A}

\section{SURVEY PARAMETERS AND RESULTS}

\section{Parameters}

Survey Site:

Survey Dates:

Double Tracks Site

Nellis Air Force Range near Tonopah, Nevada

April 10-13, 1995

June 5-9, 1995

Nominal Site Elevation:

$1,450-1,550 \mathrm{~m}(4,800-5,000 \mathrm{ft}) \mathrm{MSL}$

Survey Altitude:

$0.75 \mathrm{~m}$ (30 in) Kiwi (Nal) system

$0.75 \mathrm{~m}$ (30 in) ATV (FIDLER) system

$1 \mathrm{~m}$ (3 ft) HPGe tripods

$3 \mathrm{~m}(10 \mathrm{ft})$ and $7.5 \mathrm{~m}(25 \mathrm{ft})$ Suburban (HPGe) system

Line Spacing:

$3 \mathrm{~m}(10 \mathrm{ft})$ Kiwi system

$1.6 \mathrm{~m}(5 \mathrm{ft})$ ATV system

Line Direction:

Kiwi: north-south inside fenced area and approximately northwest-southeast south of fenced area.

ATV: east-west inside fence.

Survey Coverage:

Approximately $0.13 \mathrm{~km}^{2}\left(0.05 \mathrm{mi}^{2}\right)$ inside fenced area. Sporadic measurements outside fenced area.

Base of Operation:

Tonopah Test Range, Nevada.

Positioning System:

Differential GPS (Global Positioning System).

Detector Arrays:

Two tripod systems: approximately $86 \%$ and $107 \%$ efficiency HPGe.

Suburban vehicle with approximately $98 \%$ HPGe on extendable mast.

Kiwi vehicle with Nal detectors and REDAR IV.

ATV with three FIDLER detectors.

\section{Conversion Factors}

$1 \mu \mathrm{R} / \mathrm{h}=8.76 \mathrm{mR} / \mathrm{yr} \approx 8.37 \mathrm{mrem} / \mathrm{yr}$ 


\title{
APPENDIX B
}

This appendix is an unpublished internal report of some work performed in Area 11 of the NTS and is included here principally for its background information on the thermoluminescent detector (TLD) sheets and to highlight the discrete distribution of Pu at another site. One of the authors of this appendix (AB) assisted in the data collection at Double Tracks. Minor editorial changes have been made to the original document.

\section{IN SITU MEASUREMENT OF ENVIRONMENTAL ALPHA ACTIVITY AT VERY HIGH SPATIAL RESOLUTION AND SENSITIVITY}

\author{
A. BHATTACHARJIE AND W. QUAM \\ EG\&G/EM SANTA BARBARA OPERATIONS
}

\begin{abstract}
Large $(30 \mathrm{~cm}$ by $30 \mathrm{~cm})$ TLD sheets were used to determine the surface and depth distribution of ${ }^{239} \mathrm{Pu}$ alpha contamination at a location on the Nevada Test Site. The spatial resolution was $3 \mathrm{~mm}$ at a signal to noise ratio exceeding 20 to 1. Depth profiles were analyzed to derive their characteristic shape. Selected graphs of the raw alpha distributions, from surface and depth distributed activities, are shown.
\end{abstract}

\section{Introduction}

Recent work by International Sensor Technology (IST) in Pullman, WA, has yielded several large area TLD products. One such TLD, a calcium sulfate (thulium activator) was used for the in situ alpha contamination measurements reported here. These TLD materials are provided in sheet form approximately $30 \mathrm{~cm}$ by $30 \mathrm{~cm}$ with individual TLD's located on 3-mm centers on the surface of the Kapton backing. The TLD material is held on the sheet surface with a binder of a few microns thickness. The alpha sensitivity is sufficient to activate the TLD traps in the TLD material.

The TLD sheets are robust and may be readily handled for placement. The sheets are reusable and can be readout several hundred times. The TLD sheets are sensitive to betas and gammas as well as alphas; however, the higher linear energy transfer of the alpha produces a larger signal per incident particle. Thus the sheets can be used to discriminate between the three radiations by setting up a discrimination threshold based upon signal to noise ratio.

Calibration measurements with ${ }^{241} \mathrm{Am}$ show that the sensitivity of this TLD material was $0.3 \mathrm{pCi}$ for a 20 -minute exposure time. We believe that this sensitivity can be increased by a large margin by improving the readout technique. The manufacturer (Dr. Braunlich of IST) has stated that recent improvements in readout technique can yield up to a factor of 100 in alpha detection sensitivity.

\section{Description of the Field Experiment}

The measurements were performed on several occasions within the fenced Site B in Area 11 at the Nevada Test Site. This area is available for evaluation of detectors that are not usually used for in situ measurements. The present work was performed for a DOE environmental restoration project.

The TLD sheets were manually placed on the soil surface to create surface maps and pressed vertically into the subsurface with a hammer-driven emplacement tool to create vertical profile maps. The major objectives were to observe the detector performance in high ground temperatures with sun at zenith and to determine feasibility of locating minute plutonium "hot particles" on site. Exposure times of 15 to 70 minutes were used, with good data 
obtained over this range. After exposure the TLD's were read out with an IST automatic reader using a pulsed carbon dioxide laser. The readout process takes about one hour.

The data are obtained as a three-dimensional array and can be drawn as an XYZ plot from a personal computer file with the alpha activity plotted as the $Z$ coordinate and the soil surface shown as the $X Y$ plane. These files can readily be manipulated to determine the statistical parameters of alpha activity within user-selected XY domains.

Three different TLD sheet materials were field tested to determine noise figures and detection sensitivities. Although ground temperatures were not measured, the air temperature was in the vicinity of $108^{\circ} \mathrm{F} ;$ i.e. , less than ideal for this material. Nonetheless, the data obtained were fairly noise free, with calcium sulfate (thulium activator) being the most sensitive. The figures shown are from this material.

\section{Discussions}

As mentioned earlier, the measurements were performed at Site B in Area 11 at the Nevada Test Site. This area was used many years ago for safety shots and has a surface contamination of ${ }^{239} \mathrm{Pu}$. Cleanup of this area is currently in process.

The first plot shows the XYZ representation of data from one TLD sheet laid flat on the soil surface and exposed for 30 minutes with part of its sensitive surface covered with an alpha absorber. This measurement served to prove that the isolated large peaks were caused only by alpha. They are present in the uncovered part and not (with some exceptions) in the covered part. The peaks seen in the covered part are noise peaks caused by readout errors and would cause false alarms. The background outside the large spikes is a combination of real incident background and the noise generated during readout. These plots show nearly 10,000 pixels of data points, each the reading of an individual TLD.

The second plot is a representation of subsurface alpha activity. The TLD sheet was emplaced in the form of a cylinder about $6 \mathrm{~cm}$ in diameter. It was allowed to overlap and to extend above the soil surface. The plot shows a greatly reduced signal in the overlap region, again demonstrating that the origin of the spikes is incident alpha. Further, as expected, it shows a reduced signal in the above ground portion illustrating the higher alpha rate from soil. The third plot has been calculated from the subsurface data by integrating signal along the sheet's circumference and plotting versus depth. We see here that the alpha contamination is not uniform with depth but appears to be low for a few centimeters and then a sharp increase appears which gradually decreases versus depth. This behavior may be due to an uncontaminated overburden placed to minimize spread of the ${ }^{239} \mathrm{Pu}$.

\section{Conclusions}

Our measurements have shown that the large area, high spatial resolution TLDs provide unique capabilities for environmental cleanup of plutonium and transuranics. Its in situ usage allows pinpointing contaminants without soil removal and processing. The disposal problem is simplified. Its large area allows large soil surface coverage in reasonable mapping times. With future improvements of TLD detection sensitivities, the mapping times would be significantly reduced. Further, the sheet TLDs provide a simple quantitative means of processing surface contamination with high spatial resolution. Minute "hot particles" would be located. Quantitative measurements of alpha contamination versus depth in soil may be readily obtained without taking soil samples for wet chemistry at a fraction of cost and time. Cost is additionally reduced by reusing the TLD sheets. 


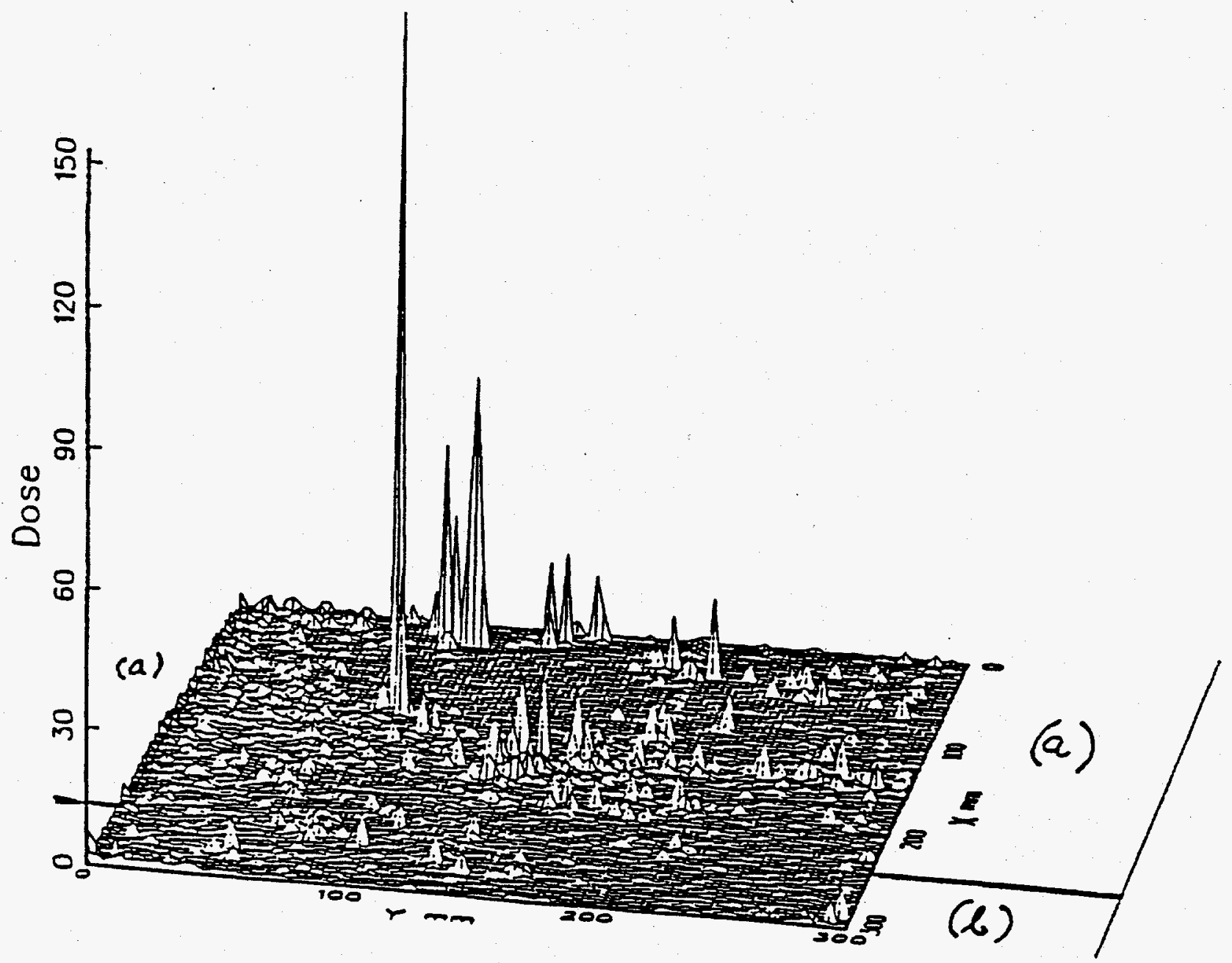

FIGURE B-1. SOLL SURFACE ALPHA MAP WITH CaSO 4 Tm (Grain Size 10 to 40 microns). Plot showing three-dimensiona! representation of 10,000 pixels of data points with the TLD sheetflaton the soilsurface andexposed for 30 minutes (a) exposed section (b) section covered with an alpha absorber. 


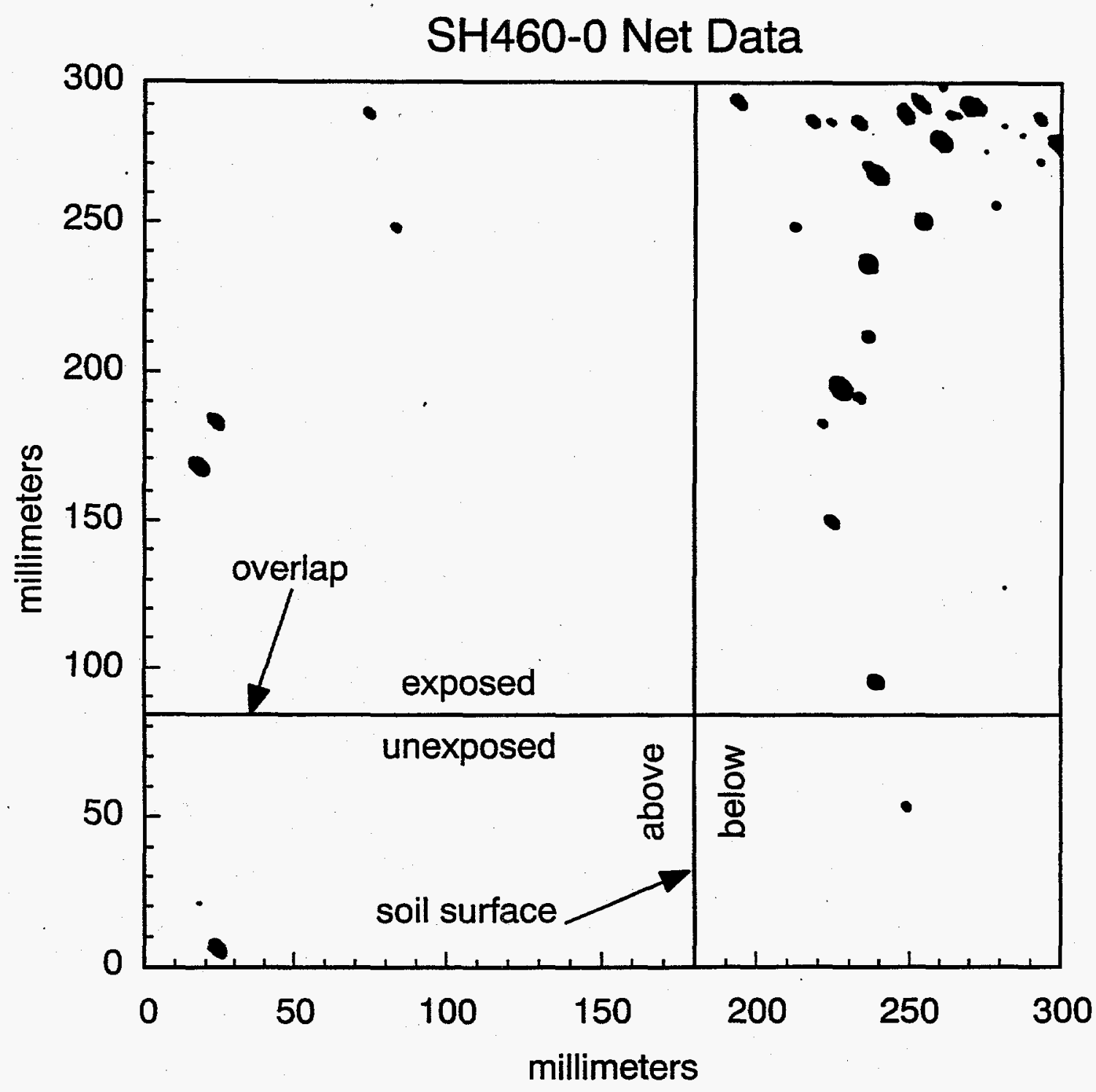

FIGURE B-2. PLOT OF SUBSURFACE ALPHA ACTIVITY. Dark spots are net signals covering several pixels each. The average background was 6,000 signal units and the largest peak was 400,000 signal units. 


\section{SH460 Average pCi/gm vs Depth \\ $\approx 54^{\prime} \mathrm{E}$ of $\mathrm{GZ}$, Site B}

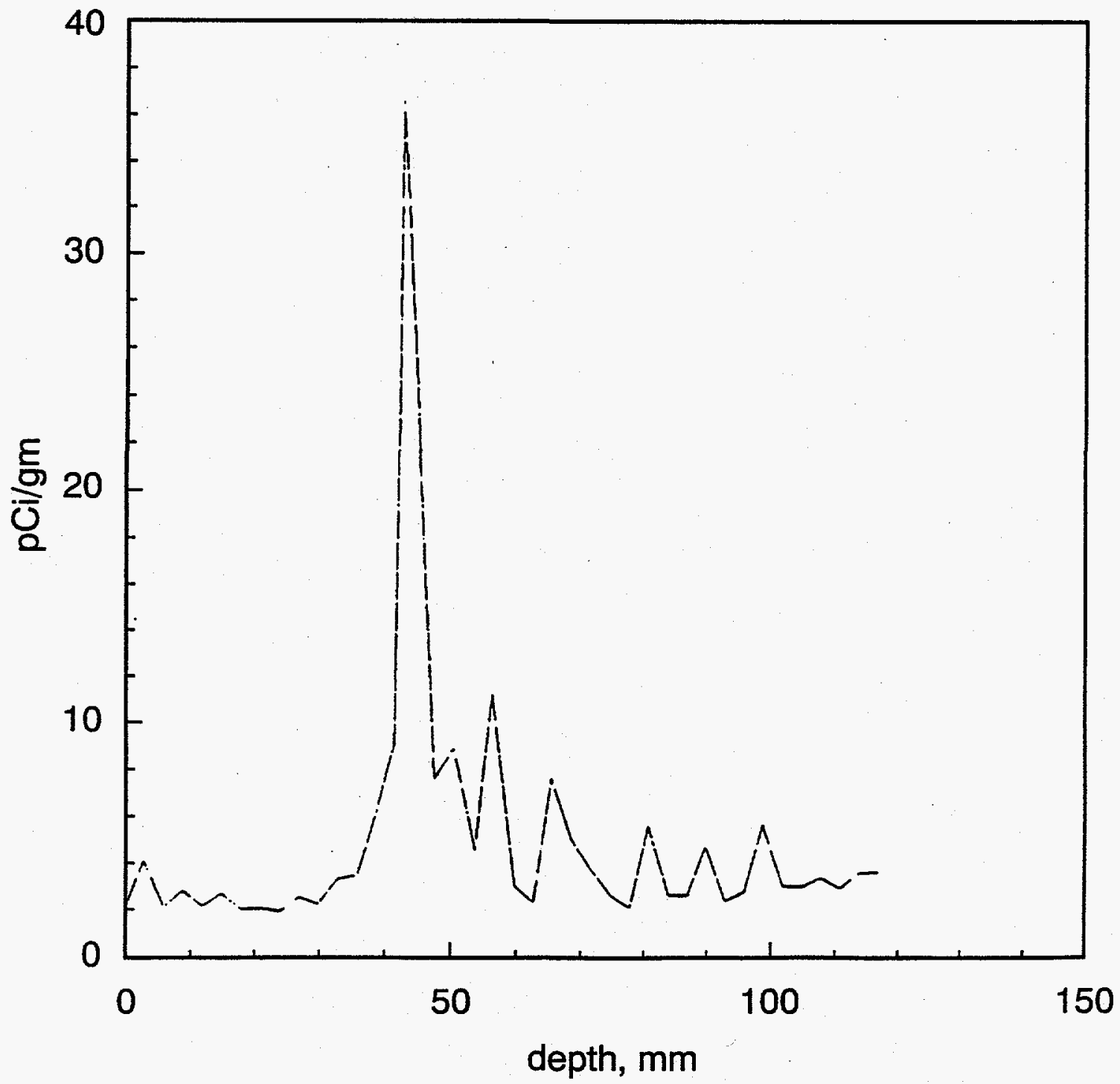

FIGURE B-3. THIS PLOT IS DERIVED FROM FIGURE B-2 AND REPRESENTS THE AVERAGE NET SIGNAL PER MINUTE INTEGRATED OVERTHETLD SHEET PORTIONTHAT WAS SUBSURFACE. Note that the signal to noise ratio is about 10:1 at $5 \mathrm{~cm}$ depth. The low signal between 0 and $5 \mathrm{~cm}$ may be due to clean soil overburden used to inhibit resuspension. 


\section{REFERENCES}

1. Schoengold, C.R., M.E. DeMarre, and E.M. McDowell. Radiological Effluents Released from Announced U.S. Continental Tests 1961 Through 1988. REECo, Las Vegas, Nevada, 1990.

2. Radiological Conditions at Project Roller Coaster Sites - 1966, Report No. NVO-162-28. REECo, Mercury, Nevada, 1967.

3. Jobst, J.E. An Aerial Radiological Survey of Clean Slates 1, 2, and 3, and Double Track, Report No. EGG-1183-1737. EG\&G, Las Vegas, Nevada, 1979.

4. Proctor, A.E., T.J. Hendricks. An Aerial Radiological Survey of the Double Track Site and Surrounding Area, Report No. EGG-11265-1086. EG\&G/EM, Las Vegas, Nevada, 1994.

5. Hendricks, T.J. Double Track Site, Report No. EGG-11265-1146. EG\&G/EM, Las Vegas, Nevada, 1995.

6. Lindeken, C.L., K.R. Peterson, D.E. Jones, and R.E. McMillen. "Geographical Variations in Environmental Radiation Background in the United States," Proceedings of the Second International Symposium on the Natural Radiation Environment, August 7-11, 1972, Houston, Texas. National Technical Information Service, Springfield, Virginia, pp 317-332, 1972.

7. Klement, Jr., A.W., C.R. Miller, R.P. Minx, and B. Shleien. Estimates of Ionizing Radiation Doses in the United States 1960-2000, U.S. EPA Report ORP/CSD72-1. EPA, Washington, D.C., 1972.

8. Reiman, R.T. In Situ Surveys of the U.S. Department of Energy's Rocky Flats Plant - Golden, Colorado, Report No. EGG-10617-1129. EG\&G/EM, Las Vegas, Nevada, 1991.

9. Beck, H.L., J. DeCampo, and C. Gogolak. In Situ Ge(Li) and NaI(Tl) Gamma Ray Spectrometry, Report No. HASL-258, TID-4500. U.S. AEC Health and Safety, Laboratory, New York, New York, 1972. 
DOE/DP
L. E. Gordon-Hagerty
O.W. Taylor

(1)

(1)

DOE/HQ

OSTI

(25)

DOE/NV

M. R. Dockter

M. Sanchez

Public Reading Room TIO

TIRC

(1)

(1)

(1)

(1)

(1)
IT

J.R. McKinley

(3)

BN

P.P. Guss WAMO (1)

R.E. Kelley LVAO

(1)

D.S. Long LVAO

C. L. Lyons LVAO

TE. Richardson LVAO

S.R. Riedhauser LVAO

W. J. Tipton

LVAO

(1)

(1)

\section{LIBRARIES}

RSL

WAMO

IN SITU RADIOLOGICAL SUFVEYING AT

THE DOUBLE TRACKS SITE

NEUIS AIR FORCE RANGE

TONOPAH, NEVADA

DOE/NV/11718-013

DATE OF SURVEY: APRIL 10-13, 1995 AND JUNE 5-9, 1995

DATE OF REPORT: MARCH 1996 

Appendix E

Vertical Profile Plots for Americium and Plutonium in Soil 



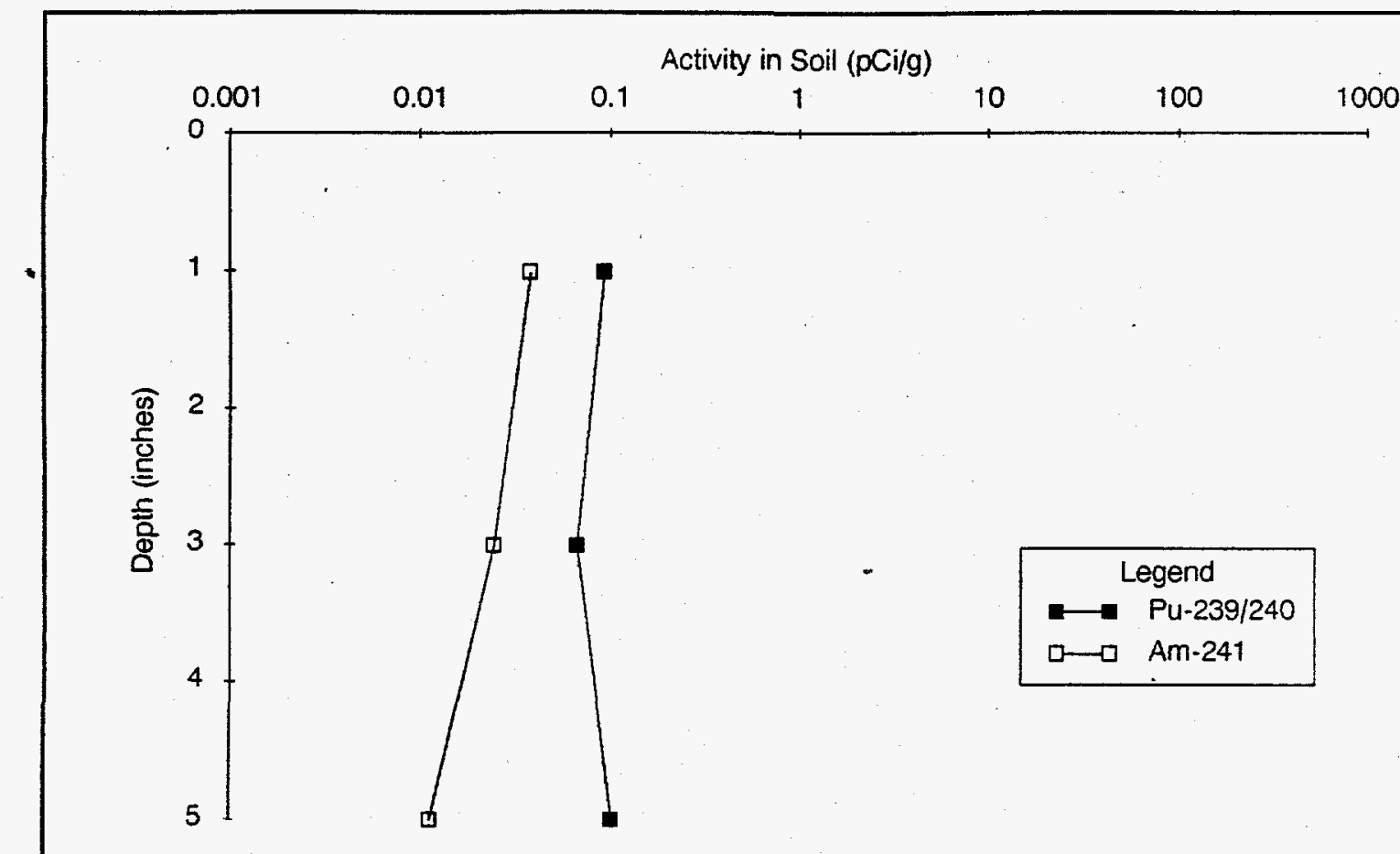

Figure E-1

Vertical Distribution of Plutonium-239/240 and Americium-241 in Double Tracks Soil Characterization Event 1, Sample Location 1

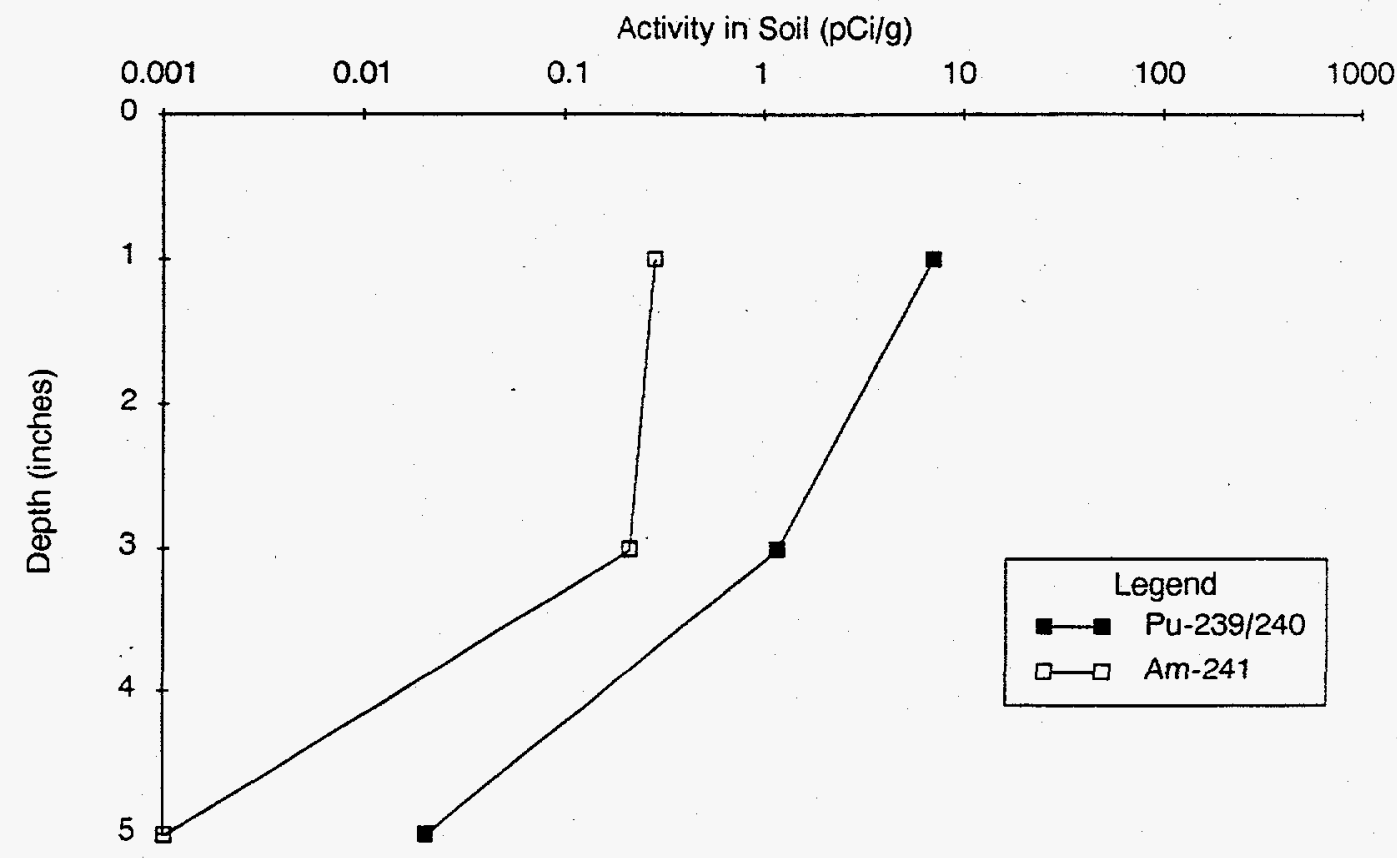

Figure E-2

Vertical Distribution of Plutonium-239/240 and Americium-241 in Double Tracks Soil Characterization Event 1, Sample Location 2 


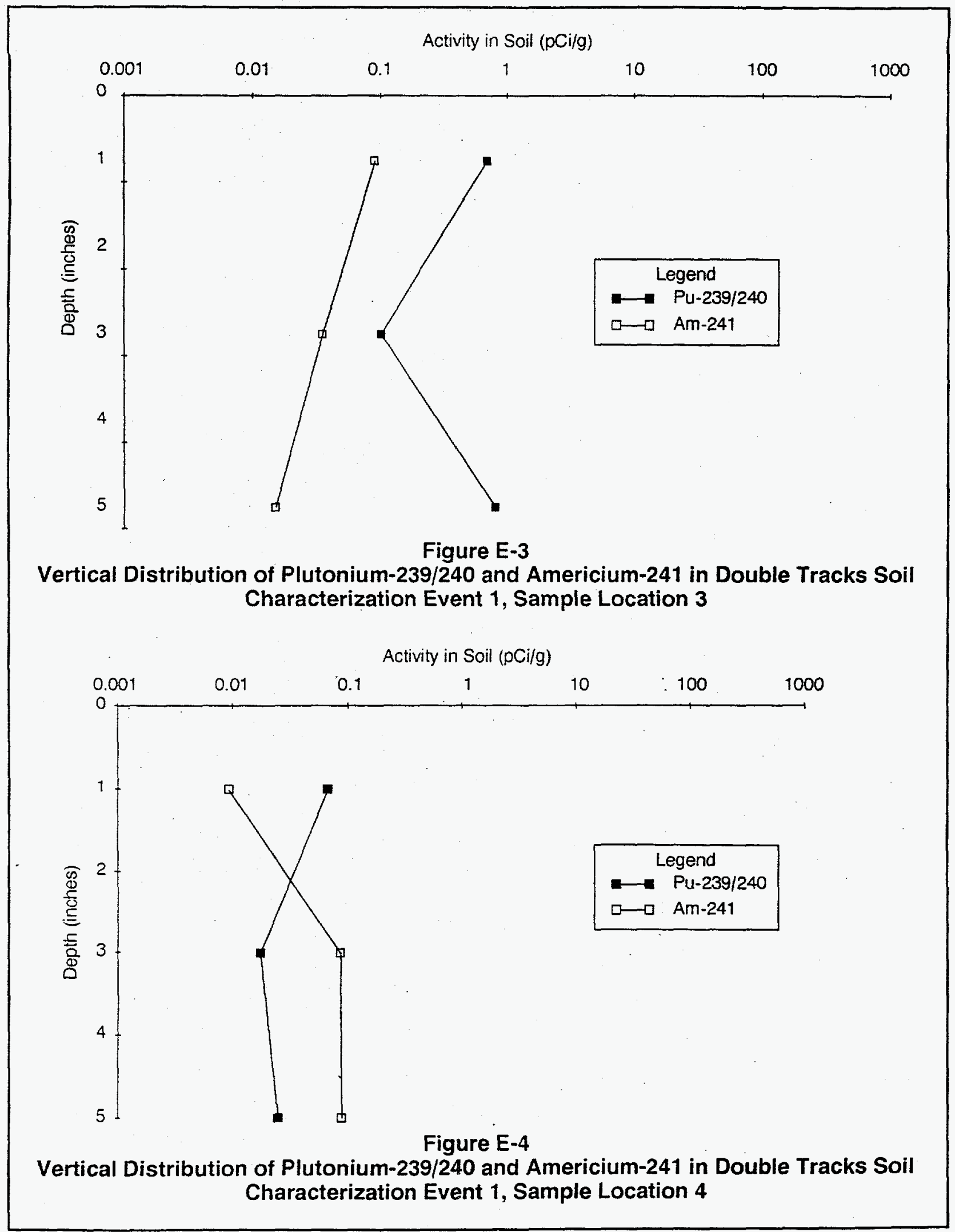




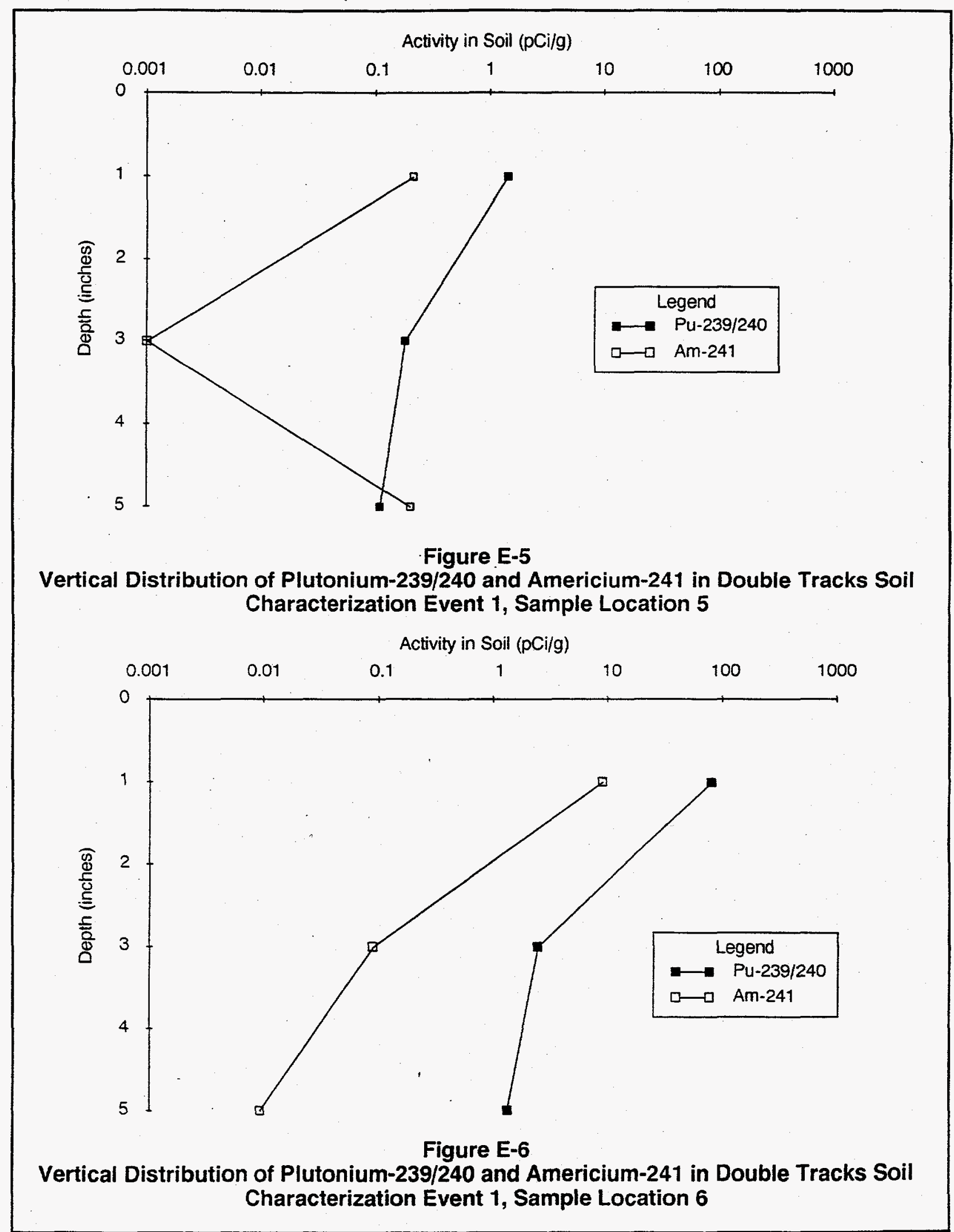

E-3 


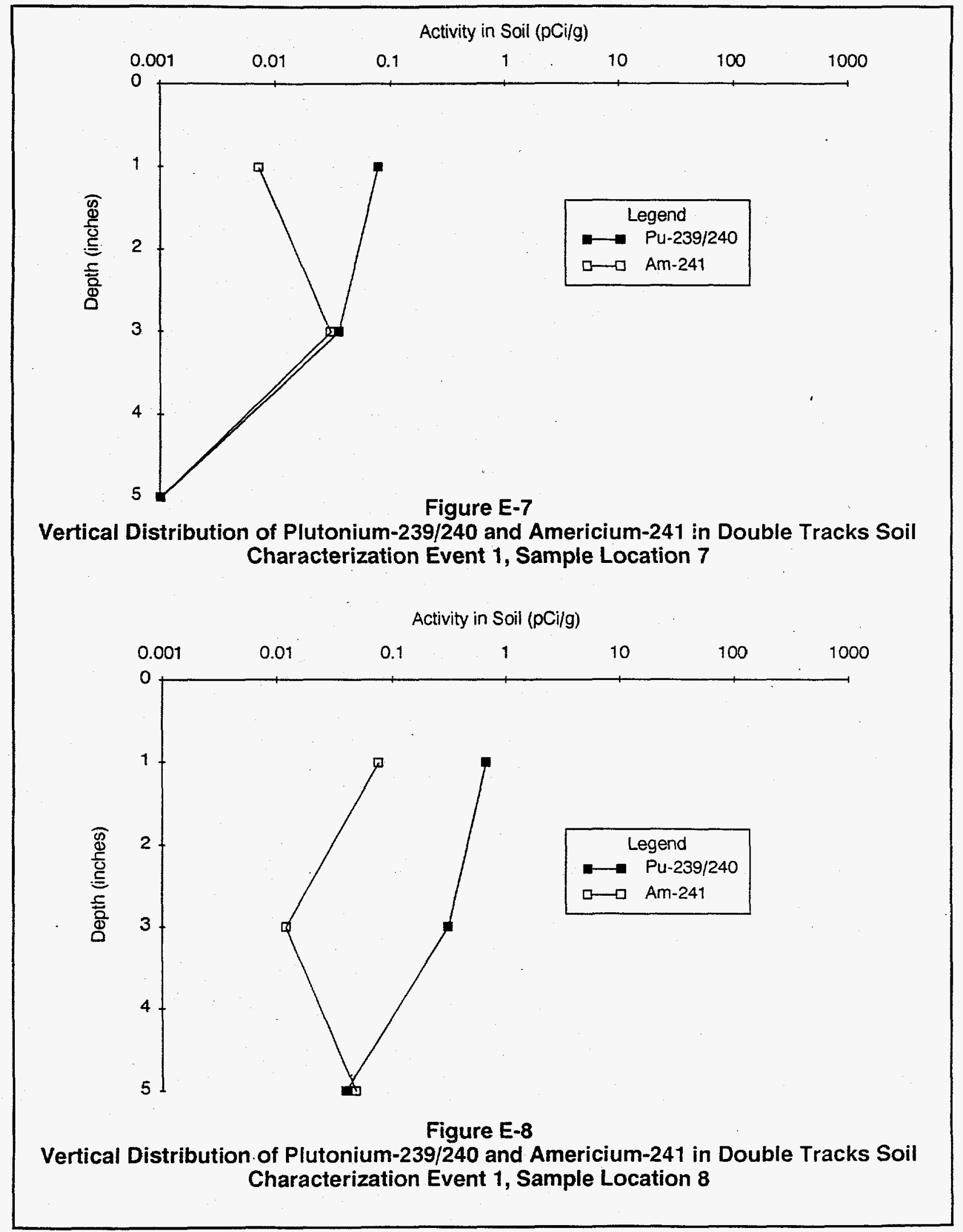




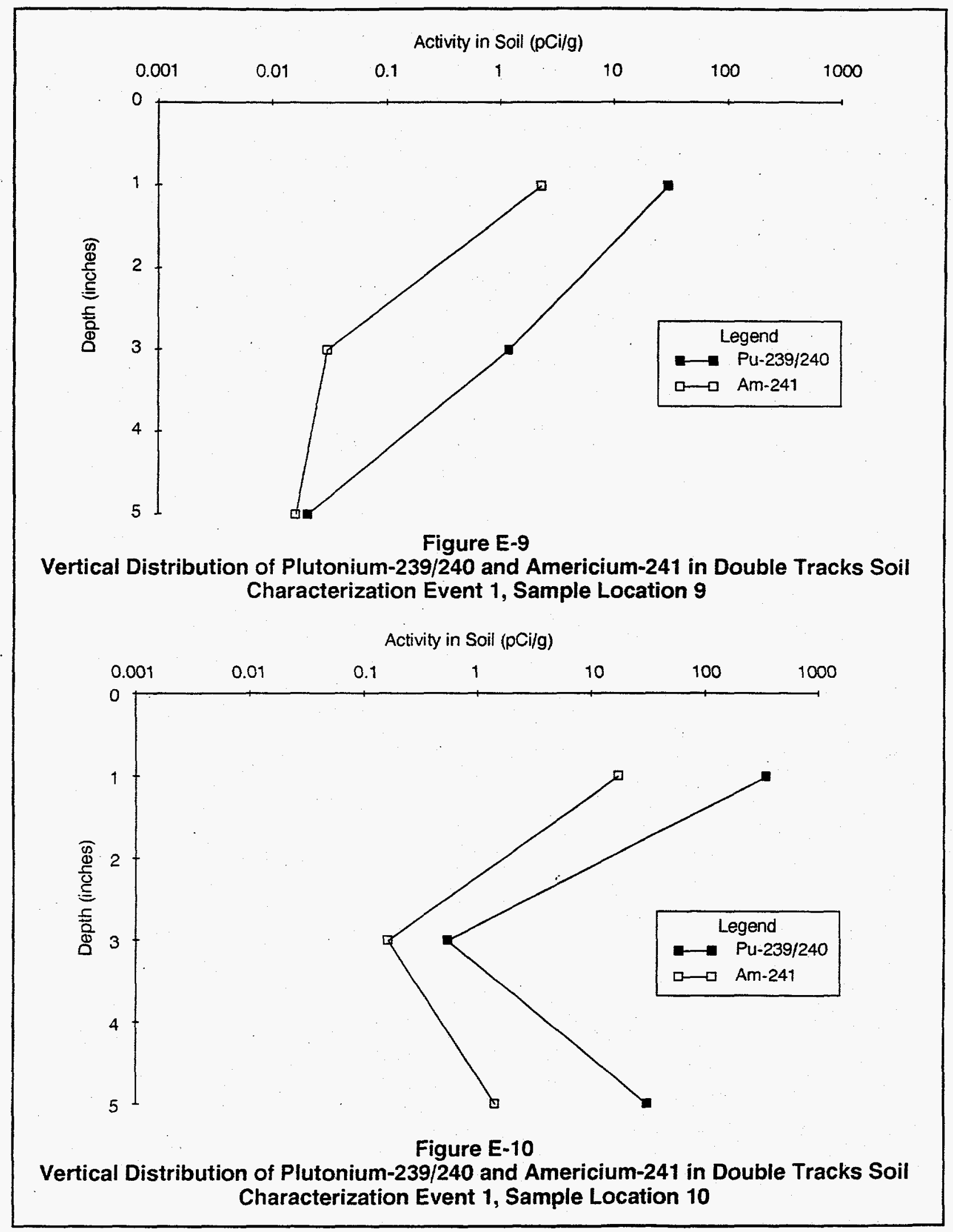




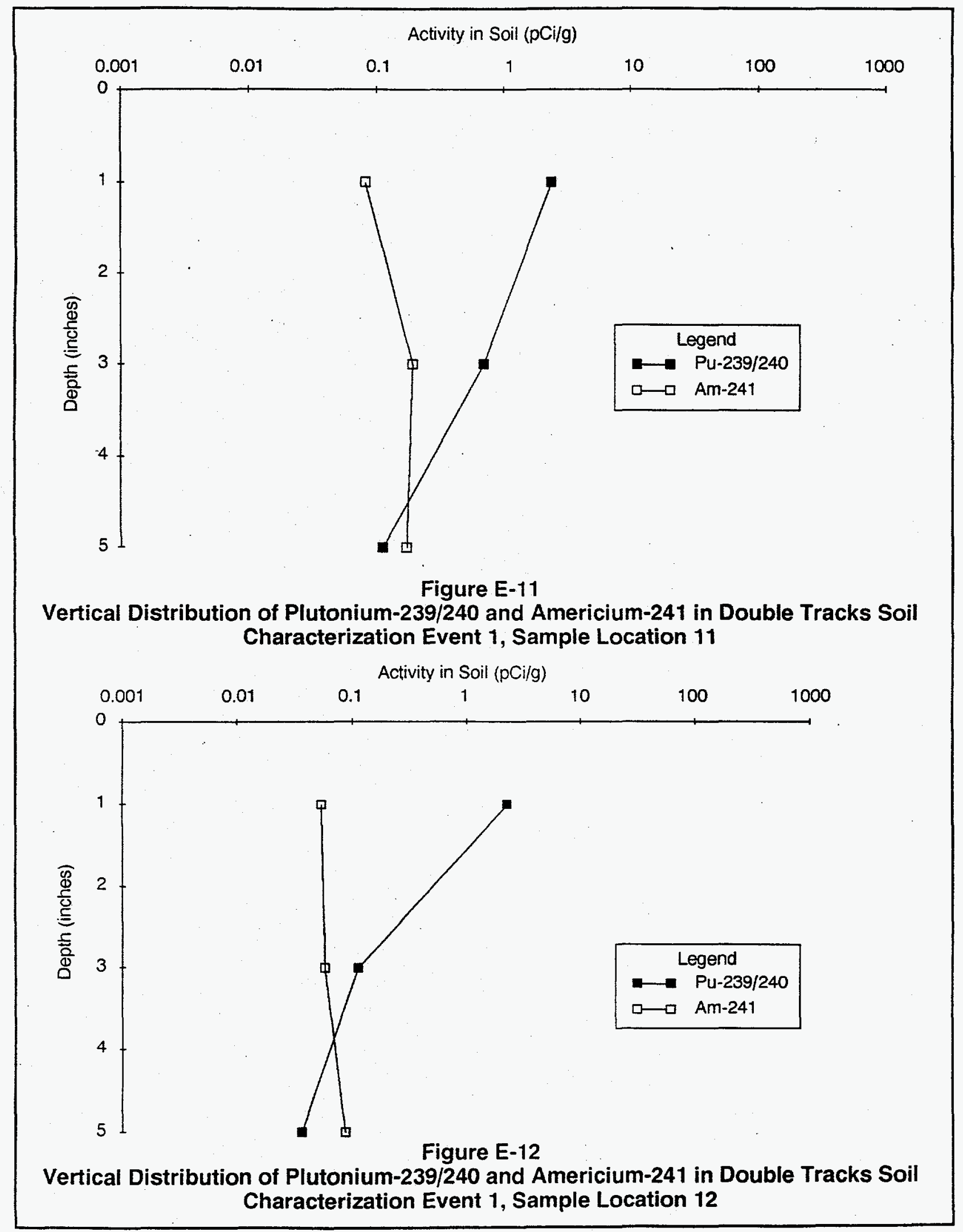


Appendix F

Soil Particle-Size and Volume Reduction Data 

Appendix $F$

Trealability Testing Results

Grain Size Analysis

IT Corporation Production Development Laboratory

Before Attrition

Scrubbing

\begin{tabular}{|c|c|c|c|c|c|}
\hline $\begin{array}{l}\text { Berore Attmuon } \\
\text { Scrubbing }\end{array}$ & & $\begin{array}{l}\text { Plus } 1600 \\
\text { plus } \# 4 \mathrm{~m}\end{array}$ & $\begin{array}{l}0 \mathrm{um} \\
\text { esh }\end{array}$ & 600 to 14 & \\
\hline & Total & & & & \\
\hline ample Number & Veight & Weight & Percent & Weight & Percent \\
\hline TT $725001 \mathrm{~A}$ & 1555.71 & 113.14 & 7.27 & 1095.94 & 70.45 \\
\hline DT 725002A & 1444.93 & 104.12 & 7.21 & 1097.56 & 75.96 \\
\hline DT 725003A & 1422.64 & 180.23 & 12.67 & 1134.10 & 79.72 \\
\hline DT 725004A & 1587.36 & 94.80 & 5.97 & 1308.20 & 82.41 \\
\hline DT 725005A & 1413.19 & 84.92 & 6.01 & 1018.18 & 72.05 \\
\hline DT 725006A & 1636.85 & 78.26 & 4.78 & 1182.20 & 72.22 \\
\hline DT 725007A & 1371,49 & 95.56 & 6.97 & 934.08 & 68.11 \\
\hline DT 725008A & 1566.25 & 165.24 & 10.55 & 1262.25 & 80.59 \\
\hline DT $725009 \mathrm{~A}$ & 1589.98 & 111.99 & 7.04 & 1103.72 & 69.42 \\
\hline $250+04$ & 1296.55 & 82.56 & 6.37 & 1186.28 & 91.50 \\
\hline Average & 1488.50 & 111.08 & 7.48 & 1132.25 & 76.24 \\
\hline
\end{tabular}

\begin{tabular}{|c|c|c|c|c|c|}
\hline \multirow{2}{*}{$\begin{array}{l}\text { Total Minus } \\
\# 100 \text { Mesh } \\
\text { Percent }\end{array}$} & $\begin{array}{l}149 \text { to } 74 \mathrm{u} \\
\# 100 \text { to } \# 2\end{array}$ & Mesh & \multicolumn{2}{|c|}{ Minus 74 um } & $\begin{array}{l}\text { Total Plus } \\
\text { 100\# Mesh }\end{array}$ \\
\hline & $\begin{array}{l}\text { Weight } \\
203.55\end{array}$ & $\begin{array}{r}\text { Percent } \\
13.08\end{array}$ & $\begin{array}{l}\text { Weight } \\
143.08\end{array}$ & $\begin{array}{r}\text { Percent } \\
9.20\end{array}$ & $\begin{array}{r}\text { Percent } \\
22.28\end{array}$ \\
\hline 83.17 & 156.41 & 10.82 & 86.84 & 6.01 & 16.83 \\
\hline 92.39 & 92.20 & 6.48 & 16.11 & 1.13 & 7.61 \\
\hline 88.39 & 147.91 & 9.32 & 36.45 & 2.30 & 11.61 \\
\hline 78.06 & 269.18 & 19.05 & 40.91 & 2.89 & 21.94 \\
\hline 77.01 & 310.79 & 18.99 & 65.60 & 4.01 & 22.99 \\
\hline 75.07 & 206.37 & 15.05 & 135.48 & 9.88 & 24.93 \\
\hline 91.14 & 121.53 & 7.76 & 17.23 & 1.10 & 8.86 \\
\hline 76.46 & 318.10 & 20.01 & 56.17 & 3.53 & 23.54 \\
\hline 97.86 & 22.26 & 1.72 & 5.45 & 0.42 & 2.14 \\
\hline 83.73 & 184.83 & 12.23 & 60.33 & 4.05 & 16.27 \\
\hline 64.91 & & & & & 35.09 \\
\hline 70.25 & & & & & 29.75 \\
\hline 76.58 & & & & & 23.42 \\
\hline 61.7 & & & & & 38.3 \\
\hline 57.32 & & & & & 42.68 \\
\hline 62.47 & & & & & 37.53 \\
\hline
\end{tabular}

After Attrition

Scrubbing

DT $725001 \mathrm{~A}$

DT 725002A

i) DT 725003A

DT 725005A

DT 725006A

Desert Research Institute

Before Attrition

Scrubbing

Sample Number

DT $725001 B$

DT 725002B

DT $725003 B$

DT $725004 \mathrm{~B}$

DT 725005B

DT 725006B

DT 725007B

DT $725008 B$

DT 725009B

DT 725010B Total

Weight Weight Percent Weight Percent

$\begin{array}{llllll}197.70 & 43.30 & 21.90 & 77.20 & 39.05\end{array}$

$\begin{array}{lllll}198.70 & 40.70 & 20.48 & 84.70 & 42.63\end{array}$

$\begin{array}{lllll}196.30 & 40.00 & 20.38 & 87.70 & 44.68\end{array}$

$\begin{array}{lllll}198.60 & 34.50 & 17.37 & 70.30 & 35.40\end{array}$

$\begin{array}{lllll}198.20 & 24.10 & 12.16 & 66.10 & 33.35\end{array}$

$\begin{array}{lllll}198.80 & 33.50 & 16.85 & 76.10 & 38.28\end{array}$

$\begin{array}{lllll}198.70 & 50.90 & 25.62 & 71.30 & 35.88\end{array}$

$\begin{array}{lllll}197.80 & 56.70 & 28.67 & 91.40 & 46.21\end{array}$

$\begin{array}{llllll}198.50 & 31.40 & 15.82 & 70.60 & 35.57\end{array}$

$\begin{array}{llllll}198.20 & 35.10 & 17.71 & 67.20 & 33.91\end{array}$

Average

$\begin{array}{lllll}198.15 & 39.02 & 19.70 & 76.26 & 38.49\end{array}$

$$
\begin{array}{r}
\text { Weight } \\
28.10 \\
32.20 \\
30.10 \\
35.20 \\
36.90 \\
36.10 \\
29.90 \\
21.90 \\
35.50 \\
38.60 \\
32.45
\end{array}
$$$$
\text { 28.10 Percent }
$$

125 to 75 um

75 to 38 um

Minus 38 um

$\begin{array}{rrr}\text { Percent } & \text { Weight } & \text { Percent } \\ 9.26 & 11.70 & 5.92 \\ 6.54 & 9.60 & 4.83 \\ 6.21 & 8.90 & 4.53 \\ 9.21 & 16.30 & 8.21 \\ 13.57 & 12.30 & 6.21 \\ 9.31 & 9.60 & 4.83 \\ 8.30 & 7.50 & 3.77 \\ 4.35 & 6.80 & 3.44 \\ 10.38 & 13.10 & 6.60 \\ 9.08 & 14.10 & 7.11 \\ 8.62 & 10.99 & 5.55\end{array}$


Appendix F

Gamma Spectrography

plus 100 mesh Size Fraction

Radiological Results

(Uncertainties reported as percent at 2-sigma)

\begin{tabular}{|c|c|c|c|c|c|c|c|c|c|c|c|}
\hline Nuclide $(p \mathrm{p} i / g)$ & MDA & SN-GG\#6854 & $\mathrm{a}$ & SN-GG\#6855 & $\mathrm{a}$ & SN-GG\#6856 & $\mathrm{a}$ & SN-GG\#6857 & $\mathrm{a}$ & SN-GG\#6858 & a \\
\hline Ac-228 & 0.0320 & $1.5 \pm 10$ & & $1.6 \pm 10$ & & $1.4 \pm 10$ & & $1.4 \pm 10$ & & $1.5 \pm 11$ & \\
\hline Am:241 & 0.0102 & $17.0 \pm 1$ & & $5.12 \pm 2$ & & $2.4 \pm 6$ & & $16.2 \pm 1$ & & $1.5 \pm 7$ & \\
\hline $\mathrm{Bi}-214$ & 0.0070 & $0.96 \pm 10$ & & $1.1 \pm 8$ & & $1.1 \pm 8$ & & $1.1 \pm 8$ & & $1.0 \pm 8$ & \\
\hline Cs-137 & 0.00448 & $0.19 \pm 19$ & & $0.14 \pm 23$ & & $0.18 \pm 15$ & & $0.18 \pm 16$ & & $0.30 \pm 13$ & \\
\hline $\mathrm{K}-40$ & 0.035 & $27 \pm 6$ & & $28 \pm 6$ & & $28 \pm 6$ & & $25 \pm 6$ & & $27 \pm 6$ & \\
\hline Np-237 & 0.0842 & 0.0842 & $\mathrm{U}$ & 0.0842 & $\mathrm{U}$ & 0.0842 & $\mathrm{U}$ & 0.0842 & $\mathrm{U}$ & 0.0842 & $\mathrm{U}$ \\
\hline $\mathrm{Pb}-212$ & 0.0104 & $1.1 \pm 6$ & & $1.5 \pm 6$ & & $1.6 \pm 6$ & & $1.4 \pm 6$ & & $1.6 \pm 6$ & \\
\hline $\mathrm{Pb}-214$ & 0.0056 & $1.0 \pm 8$ & & $1.1 \pm 8$ & & $0.99 \pm 9$ & & $1.1 \pm 8$ & & $1.0 \pm 8$ & \\
\hline $\mathrm{Pu}-241$ & 4095 & 4095 & $\mathrm{U}$ & 4095 & $\mathrm{U}$ & 4095 & $\mathrm{U}$ & 4095 & $\mathrm{U}$ & 4095 & U \\
\hline $\mathrm{Pu}-240$ & 61.9 & 61.9 & $\mathrm{U}$ & 61.9 & $\mathrm{U}$ & 61.9 & $\mathrm{U}$ & 61.9 & $\mathrm{U}$ & 61.9 & $\mathrm{U}$ \\
\hline Pu-239 & 15.5 & 15.5 & U & 15.5 & $\mathrm{U}$ & 15.5 & $\mathrm{U}$ & 15.5 & $\mathbf{U}$ & 15.5 & $\mathrm{U}$ \\
\hline Th-228 & 0.911 & 0.911 & $\mathrm{U}$ & 0.911 & $\mathrm{u}$ & 0.911 & $\mathrm{U}$ & 0.911 & $\mathrm{U}$ & 0.911 & $\mathrm{U}$ \\
\hline Th-229 & 0.0066 & 0.0066 & $\mathrm{U}$ & 0.0066 & $\mathrm{U}$ & 0.0066 & $\mathrm{U}$ & 0.0066 & $\mathrm{U}$ & 0.0066 & $\mathrm{U}$ \\
\hline TI-208 & 0.0012 & $0.47 \pm 7$ & & $0.58 \pm 6$ & & $0.55 \pm 6$ & & $0.50 \pm 6$ & & $0.59 \pm 5$ & \\
\hline $\mathrm{Pa}-231$ & 0.245 & 0.245 & U & 0.245 & $\bar{U}$ & 0.245 & $\bar{U}$ & 0.245 & $\mathbf{U}$ & 0.245 & U \\
\hline U-235 & 0.0054 & 0.0054 & $\mathrm{U}$ & 0.0054 & $\bar{U}$ & 0.0054 & $\mathrm{U}$ & 0.0054 & $\mathrm{U}$ & 0.0054 & $\mathrm{U}$ \\
\hline
\end{tabular}


Appendix F

Gamma Spectrography

plus 100 mesh Size Fraction

Radiological Results

(Uncertainties reported as percent at 2-sigma)

\begin{tabular}{|c|c|c|c|c|c|c|c|c|c|c|c|}
\hline Nuclide $(p \mathrm{Ci} / \mathrm{g})$ & MDA & SN-GG\#6859 & $\mathrm{Q}$ & SN-GG $\# 6860$ & $a$ & SN-GG $/ 16861$ & 0 & SN-GG $\# 6862$ & $\mathrm{Q}$ & SN-GG \#6863 & 0 \\
\hline$A c-228$ & 0.0320 & $1.5 \pm 11$ & & $1.4 \pm 11$ & & $1.4 \pm 9$ & & $1.4 \pm 9$ & & $1.4 \pm 11$ & \\
\hline Am-241 & 0.0102 & $10.9 \pm 4$ & & $19.7 \pm 1$ & & $1.91 \pm 4$ & & $6.7 \pm 2$ & & $7.4 \pm 4$ & \\
\hline $\mathrm{Bi}-214$ & 0.0070 & $1.0 \pm 9$ & & $1.1 \pm 8$ & & $0.92 \pm 8$ & & $0.94 \pm 8$ & & $1.1 \pm 8$ & \\
\hline Cs-137 & 0.00448 & $0.33 \pm 11$ & & $0.44 \pm 10$ & & 0.00448 & $\bar{U}$ & $0.1 \pm 24$ & & $0.26 \pm 14$ & \\
\hline $\mathrm{K}-40$ & 0.035 & $26 \pm 6$ & & $27 \pm 6$ & & $24: 6$ & & $25 \pm 6$ & & $24 \pm 6$ & \\
\hline $\mathrm{Np}-237$ & 0.0842 & 0.0842 & $\bar{U}$ & 0.0842 & $\bar{U}$ & 0.0842 & $\mathrm{U}$ & 0.0842 & $\bar{U}$ & 0.0842 & $\bar{U}$ \\
\hline $\mathrm{Pb}-212$ & 0.0104 & $1.4 \pm 6$ & & $1.4 \pm 6$ & & $1.4 \pm 6$ & & $1.4 \pm 6$ & & $1.5 \pm 6$ & \\
\hline Pb-214 & 0.0056 & $1.0 \pm 8$ & & $1.1 \pm 8$ & & $1.0 \pm 8$ & & $1.1 \pm 8$ & & $1.1 \pm 8$ & \\
\hline Pu-241 & 4095 & 4095 & $\mathrm{U}$ & 4095 & $\mathrm{U}$ & 4095 & $\mathrm{U}$ & 4095 & $\mathrm{U}$ & 4095 & $\mathrm{U}$ \\
\hline Pu-240 & 61.9 & 61.9 & $\mathrm{U}$ & 61.9 & $\mathrm{U}$ & 61.9 & $\mathrm{U}$ & 61.9 & U & 61.9 & U \\
\hline Pu-239 & 15.5 & 15.5 & $\mathrm{U}$ & 15.5 & $\mathrm{U}$ & 15.5 & $\mathrm{U}$ & 15.5 & $\mathrm{U}$ & 15.5 & $\mathrm{U}$ \\
\hline Th-228 & 0.911 & 0.911 & $\mathrm{U}$ & 0.911 & $\mathrm{U}$ & 0.911 & $\mathrm{U}$ & 0.911 & $\mathrm{U}$ & 0.911 & $\mathrm{U}$ \\
\hline Th-229 & 0.0066 & 0.0066 & $\mathrm{U}$ & 0.0066 & $\mathrm{U}$ & 0.0066 & $\mathrm{U}$ & 0.0066 & $\mathrm{U}$ & 0.0066 & $U$ \\
\hline $\mathrm{TI}-208$ & 0.0012 & $0.53 \pm 6$ & & $0.53 \pm 6$ & & $0.44 \pm 6$ & & $0.49 \pm 6$ & & $0.46 \pm 7$ & \\
\hline $\mathrm{Pa}-231$ & 0.245 & 0.245 & U & 0.245 & $\bar{U}$ & 0.245 & $\mathrm{U}$ & 0.245 & $U$ & 0.245 & $\bar{U}$ \\
\hline $\mathrm{U}-235$ & 0.0054 & 0.0054 & $\mathrm{U}$ & 0.0054 & $\bar{U}$ & 0.0054 & $\mathrm{U}$ & 0.0054 & U. & 0.0054 & $\mathrm{U}$ \\
\hline
\end{tabular}


Appendix F

Gamma Spectrography

After Attrition Scrubbing - plus 100 mesh Size Fraction

Radiological Results

(Uncertainties reported as percent at 2 -sigma)

\begin{tabular}{|c|c|c|c|c|c|c|c|c|c|c|c|}
\hline Nuclide $(\mathrm{pCi} / \mathrm{g})$ & MDA & SN-GG\#6854A & $\mathrm{Q}$ & SN-GG\#6855A & $\mathrm{a}$ & SN-GG\#6856A & $\mathrm{Q}$ & SN-GG\#6857A & $\mathrm{a}$ & SN-GG\#6858A & $\mathrm{Q}$ \\
\hline$A c-228$ & 0.0320 & $1.4 \pm 18$ & & $1.6 \pm 18$ & & $1.6 \pm 18$ & & $1.7 \pm 21$ & & $1.7 \pm 17$ & \\
\hline $\mathrm{Am} \cdot 241$ & 0.0102 & $3.0 \pm 4$ & & $6.5 \pm 6$ & & $2.6 \pm 8$ & & $6.4 \pm 6$ & & $8.2 \pm 5$ & \\
\hline $\mathrm{Bi}-214$ & 0.0070 & $1.1 \pm 13$ & & $1.2 \pm 13$ & & $1.2 \pm 13$ & & $1.3 \pm 13$ & & $1.4: 13$ & \\
\hline Cs-137 & 0.00448 & $0.50 \pm 15$ & & 0.00448 & $\mathrm{U}$ & $0.16 \pm 47$ & & 0.00448 & $\bar{U}$ & $0.25 \pm 32$ & \\
\hline$K^{\prime}-40$ & 0.035 & $18 \pm 9$ & & $32 \pm 8$ & & $33 \pm 8$ & & $33 \pm 8$ & & $33 \pm 8$ & \\
\hline $\mathrm{Np}-237$ & 0.0842 & 0.0842 & $\mathrm{U}$ & 0.0842 & $\bar{U}$ & 0.0842 & $\mathrm{U}$ & 0.0842 & $\mathrm{U}$ & 0.0842 & $\mathrm{U}$ \\
\hline $\mathrm{Pb}-212$ & 0.0104 & $1.3 \pm 9$ & & $1.7 \pm 9$ & & $1.8 \pm 9$ & & $1.7 \pm 9$ & & $1.8 \pm 8$ & \\
\hline $\mathrm{Pb}-214$ & 0.0056 & $1.1 \pm 15$ & & $1.3 \pm 12$ & & $1.3 \pm 13$ & & $1.3 \pm 1.2$ & & $1.3 \pm 13$ & \\
\hline Pu-241 & 4095 & 4095 & $\underline{U}$ & 4095 & $\mathrm{U}$ & 4095 & $\mathrm{U}$ & 4095 & $\mathrm{U}$ & 4095 & $U$ \\
\hline $\mathrm{Pu}-240$ & 61.9 & 61.9 & $\mathrm{U}$ & 61.9 & $\mathbf{U}$ & 61.9 & $\mathrm{U}$ & 61.9 & $\mathrm{U}$ & 61.9 & $\mathrm{U}$ \\
\hline $\mathrm{Pu}-239$ & 15.5 & $498 \pm 75$ & & 15.5 & $\mathbf{U}$ & 15.5 & $\mathrm{U}$ & 15.5 & $\bar{U}$ & 15.5 & $\mathrm{U}$ \\
\hline Th-228 & 0.911 & 0.911 & $\mathbf{U}$ & 0.911 & $U$ & 0.911 & $\mathrm{U}$ & 0.911 & $U$ & 0.911 & $\bar{U}$ \\
\hline Th-229 & 0.0066 & 0.0066 & $\mathrm{U}$ & 0.0066 & $\mathrm{U}$ & 0.0066 & $\mathrm{U}$ & 0.0066 & $U$ & 0.0066 & $\bar{U}$ \\
\hline $\mathrm{Tl}-208$ & 0.0012 & $0.48 \pm 12$ & & $0.63 \pm 11$ & & $0.63 \pm 12$ & & $0.67 \pm 11$ & & $0.68 \pm 17$ & \\
\hline $\mathrm{Pa}-231$ & 0.245 & 0.245 & $\mathrm{U}$ & 0.245 & $\mathrm{U}$ & 0.245 & $\mathbf{U}$ & 0.245 & $\mathrm{U}$ & 0.245 & $\mathrm{U}$ \\
\hline U-235 & 0.0054 & 0.0054 & $\bar{U}$ & $0.23 \pm 29$ & & $0.16 \pm 32$ & & 0.0054 & $\mathrm{U}$ & $0.16 \pm 39$ & \\
\hline
\end{tabular}


Appendix F

Gamma Spectrography

After Attrition Scrubbing - plus 100 mesh Size Fraction

Radiological Results

(Uncertainties reported as percent at 2-sigma)

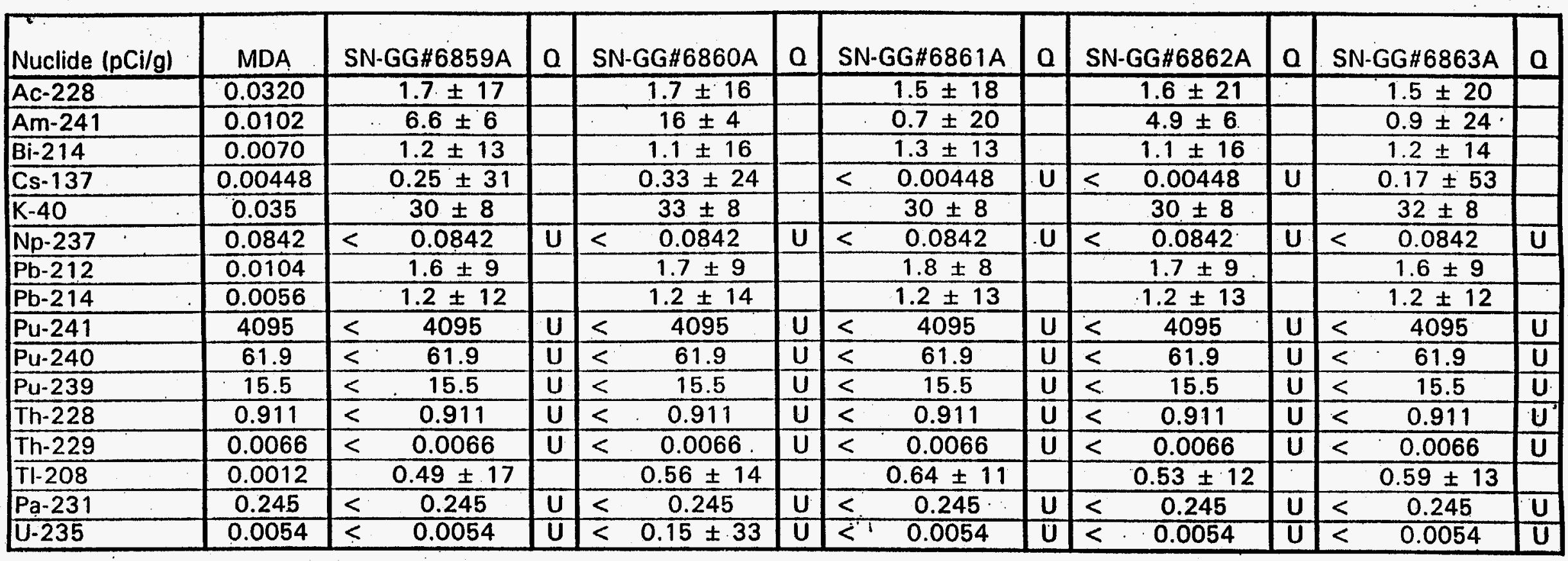


Appendix $F$

Treatability Study

Isotopic Laboratory Results in Soil

(after attrition scrubbing)

\begin{tabular}{|c|c|c|c|c|c|c|}
\hline $\begin{array}{l}\text { Soil Fraction } \\
\text { Type }\end{array}$ & Sample Number & Isotope & Activity & Units & 2 Sigma & MDA \\
\hline Coarse & DT725001A & Plutonium 238 & 1.3 & $\mathrm{pCi} / \mathrm{g}$ & 5.8 & 17.7 \\
\hline Coarse & DT725001A & Plutonium 239/240 & 30.8 & $\mathrm{pCi} / \mathrm{g}$ & 19.8 & 15.1 \\
\hline Coarse & DT725001A & Americium 241 & 1.86 & $\mathrm{pCi} / \mathrm{g}$ & 0.58 & 0.16 \\
\hline Coarse & DT725002A & Plutonium 238 & 0.08 & $\mathrm{pCi} / \mathrm{g}$ & 0.35 & 1.08 \\
\hline Coarse & DT725002A & Plutonium 239/240 & 4.69 & $\mathrm{pCi} / \mathrm{g}$ & 1.98 & 0.79 \\
\hline Coarse & DT725002A & Americium 241 & 0.55 & $\mathrm{pCi} / \mathrm{g}$ & 0.27 & 0.19 \\
\hline Coarse & DT725003A & Plutonium 238 & 2.8 & $\mathrm{pCi} / \mathrm{g}$ & 1.58 & 0.75 \\
\hline Coarse & DT725003A & Plutonium 239/240 & 413 & $\mathrm{pCi} / \mathrm{g}$ & 72 & 0.8 \\
\hline Coarse & DT725003A & Americium 241 & 18 & $\mathrm{pCi} / \mathrm{g}$ & 5.4 & 1.6 \\
\hline Coarse & DT725004A & Plutonium 238 & $<1.76$ & $\mathrm{pCi} / \mathrm{g}$ & 0.49 & 1.76 \\
\hline Coarse & DT725004A & Plutonium 239/240 & 43.2 & $\mathrm{pCi} / \mathrm{g}$ & 9.9 & 1.6 \\
\hline Coarse & DT725004A & Americium 241 & 2.19 & $\mathrm{pCi} / \mathrm{g}$ & 0.65 & 0.17 \\
\hline Coarse & DT725005A & Plutonium 238 & 8.04 & $\mathrm{pCi} / \mathrm{g}$ & 2.38 & 0.85 \\
\hline Coarse & DT725005A & Plutonium 239/240 & 1040 & $\mathrm{pCi} / \mathrm{g}$ & 167 & 0.8 \\
\hline Coarse & DT725005A & Americium 241 & 43.4 & $\mathrm{pCi} / \mathrm{g}$ & 13.9 & 3 \\
\hline Coarse & DT725006A & Plutonium 238 & -0.19 & $\mathrm{pCi} / \mathrm{g}$ & 0.08 & 1.63 \\
\hline Coarse & DT725006A & Plutonium 239/240 & 19 & $\mathrm{pCi} / \mathrm{g}$ & 5.4 & 1.8 \\
\hline Coarse & DT725006A & Americium 241 & 1.05 & $\mathrm{pCi} / \mathrm{g}$ & 0.41 & 0.17 \\
\hline Coarse & DT725007A & Plutonium 238 & -0.07 & $\mathrm{pCi} / \mathrm{g}$ & 0.04 & 1.1 \\
\hline Coarse & DT725007A & Plutonium 239/240 & 18.5 & $\mathrm{pCi} / \mathrm{g}$ & 4.9 & 1.2 \\
\hline Coarse & DT725007A & Americium 241 & 0.55 & $\mathrm{pCi} / \mathrm{g}$ & 0.25 & 0.13 \\
\hline Coarse & DT725008A & Plutonium 238 & 0.3 & $\mathrm{pCi} / \mathrm{g}$ & 0.56 & 1.16 \\
\hline Coarse & DT725008A & Plutonium 239/240 & 2.79 & $\mathrm{pCi} / \mathrm{g}$ & 1.59 & 1.34 \\
\hline Coarse & DT725008A & Americium 241 & 0.25 & $\mathrm{pCi} / \mathrm{g}$ & 0.16 & 0.14 \\
\hline Coarse & DT725009A & Plutonium 238 & 0.33 & $\mathrm{pCi} / \mathrm{g}$ & 0.54 & 0.98 \\
\hline Coarse & DT725009A & Plutonium 239/240 & 11.7 & $\mathrm{pCi} / \mathrm{g}$ & 3.6 & 1.1 \\
\hline Coarse & DT725009A & Americium 241 & 0.32 & $\mathrm{pCi} / \mathrm{g}$ & 0.2 & 0.13 \\
\hline Coarse & DT725010A & Plutonium 238 & 0.4 & $\mathrm{pCi} / \mathrm{g}$ & 0.51 & 0.74 \\
\hline Coarse & DT725010A & Plutonium 239/240 & 12.1 & $\mathrm{pCi} / \mathrm{g}$ & 3.3 & 0.7 \\
\hline Coarse & DT725010A & Americium 241 & 0.56 & $\mathrm{pCi} / \mathrm{g}$ & 0.26 & 0.15 \\
\hline Coarse & QC Blank & Plutonium 238 & 0.16 & $\mathrm{pCi} / \mathrm{g}$ & 0.67 & 1.88 \\
\hline Coarse & QC Blank & Plutonium 239/240 & 0.76 & $\mathrm{pCi} / \mathrm{g}$ & 1.06 & 20.8 \\
\hline Coarse & QC Blank & Americium 241 & 0.07 & $\mathrm{pCi} / \mathrm{g}$ & 0.69 & 2.34 \\
\hline Coarse & QC Blank & Americium 241 & 0.11 & $\mathrm{pCi} / \mathrm{g}$ & 0.12 & 0.16 \\
\hline
\end{tabular}


Appendix $F$

Treatability Study

Isotopic Laboratory Results in Soil

(after attrition scrubbing)

Soil Fraction

Type

Sample Number Isotope

Activity

Units 2 Sigma

MDA

Coarse

QCLCS

Plutonium 238

Coarse

QCLCS

Coarse

QCLCS

Plutonium 239/240

Americium 241

$81 \%$ recovery

$104 \%$ recovery

$119 \%$ recovery

Coarse

QCLCS

Americium 241

$79 \%$ recovery

Fine

DT725001A

Plutonium 238

DT725001A

Plutonium 239/240

Fine

DT725001A

Americium 241

36.6

1460

$$
\mathrm{pCi} / \mathrm{g}
$$

9.2

$\mathrm{pCi} / \mathrm{g}$

pCi/g

36.4

334

19.9

57.4

35.6

Americium 241

pCi/g

28.2

Fine

DT725001A RE

Plutonium 238

Fine

DT725001A DUP

Plutonium 239/240

Fine

DT725001A DUP

Americium 241

19

$\mathrm{pCi} / \mathrm{g}$

25.5

35.2

1260

$\mathrm{pCi} / \mathrm{g}$

273

49.9

51.5

$\mathrm{pCi} / \mathrm{g}$

36.4

47

40.6

Fine

DT725001A DUP RE Americium 241

141

pCi/g

54

28

Fine

DT725002A

Plutonium 238

Fine

DT725002A

Plutonium 239/240

DT725002A

Americium 241

5.6

$\mathrm{pCi} / \mathrm{g}$

10.2

23

334

$\mathrm{pCi} / \mathrm{g}$

76

11.3

24

4.6

$\mathrm{pCi} / \mathrm{g}$

27.5

Fine

DT725002A RE

Americium 241

$-1.8$

$\mathrm{pCi} / \mathrm{g}$

4.9

21.1

Fine

DT725003A

Plutonium 238

Fine

DT725003A

DT725003A

Plutonium 239/240

Americium 241

2.66

$\mathrm{pCi} / \mathrm{g}$

2.2

3.25

304

pCi/g

54

3.7

12.8

$\mathrm{pCi} / \mathrm{g}$

4.3

Fine

DT725003A RE

Plutonium 238

Fine

DT725003A RE

Plutonium 239/240

1.69

$\mathrm{pCi} / \mathrm{g}$

1.23

1.4

294

$\mathrm{pCi} / \mathrm{g}$

0.9

Plutonium 238

Fine

DT725004A

Plutonium 239/240

5.86

$\mathrm{pCi} / \mathrm{g}$

491

$\mathrm{pCi} / \mathrm{g}$

Americium 241

14.5

$\mathrm{pCi} / \mathrm{g}$

3.08

3.06

DT725004A

Plutonium 238

Fine

DT725005A

Plutonium 239/240

12.7

$\mathrm{pCi} / \mathrm{g}$

1880

$\mathrm{pCi} / \mathrm{g}$

DT725005A

Americium 241

93.5

$\mathrm{pCi} / \mathrm{g}$

84

3.2

6.8

5.8

Plutonium 238

3.85

$\mathrm{pCi} / \mathrm{g}$

4.4

2.7

307

2.5

22.2

4.2

Fine

DT725005A RE

Plutonium 239/240

661

$\mathrm{pCi} / \mathrm{g}$

1.68

1.02

Plutonium 238

$-7.3$

pCi/g

110

0.9

DT725006A

Plutonium 239/240

957

$\mathrm{pCi} / \mathrm{g}$

11.1

45.3

218 
Appendix F

Treatability Study

Isotopic Laboratory Results in Soil

(after attrition scrubbing)

\begin{tabular}{|c|c|c|c|c|c|c|}
\hline $\begin{array}{l}\text { Soil Fraction } \\
\text { Type }\end{array}$ & Sample Number & Isotope & Activity & Units & 2 Sigma & MDA \\
\hline Fine & DT725006A & Americium 241 & 35.2 & $\mathrm{pCi} / \mathrm{g}$ & 22.9 & 27.8 \\
\hline Fine & DT725007A & Plutonium 238 & -1.1 & $\mathrm{pCi} / \mathrm{g}$ & 8.2 & 28.1 \\
\hline Fine & DT725007A & Plutonium 239/240 & 724 & $\mathrm{pCi} / \mathrm{g}$ & 158 & 27 \\
\hline Fine & DT725007A & Americium 241 & 1.6 & $\mathrm{pCi} / \mathrm{g}$ & 14 & 38.6 \\
\hline Fine & DT725007A RE & Americium 241 & 19.1 & $\mathrm{pCi} / \mathrm{g}$ & 13.3 & 14.7 \\
\hline Fine & DT725008A & Plutonium 238 & 0.25 & $\mathrm{pCi} / \mathrm{g}$ & 0.66 & 1.61 \\
\hline Fine & DT725008A & Plutonium 239/240 & 68 & $\mathrm{pCi} / \mathrm{g}$ & 12.7 & 1.7 \\
\hline Fine & DT725008A & Americium 241 & 1.75 & $\mathrm{pCi} / \mathrm{g}$ & 1.53 & 2.1 \\
\hline Fine & DT725008A RE & Americium 241 & 2.75 & $\mathrm{pCi} / \mathrm{g}$ & 2.19 & 2.95 \\
\hline Fine & DT725009A & Plutonium 238 & -0.12 & $\mathrm{pCi} / \mathrm{g}$ & 0.3 & 1.3 \\
\hline Fine & DT725009A & Plutonium 239/240 & 59.4 & $\mathrm{pCi} / \mathrm{g}$ & 11.2 & 1.5 \\
\hline Fine & DT725009A & Americium 241 & 2.19 & $\mathrm{pCi} / \mathrm{g}$ & 2.04 & 3.08 \\
\hline Fine & DT725009A RE & Americium 241 & 3.38 & $\mathrm{pCi} / \mathrm{g}$ & 1.94 & 1.72 \\
\hline Fine & DT725010A & Plutonium 238 & 2.37 & $\mathrm{pCi} / \mathrm{g}$ & 1.25 & 0 \\
\hline Fine & DT725010A & Plutonium 239/240 & 346 & $\mathrm{pCi} / \mathrm{g}$ & 58 & .1 \\
\hline Fine & DT725010A & Americium 241 & 9.96 & $\mathrm{pCi} / \mathrm{g}$ & 3.48 & 1.88 \\
\hline Fine & QC Blank & Plutonium 238 & 0.52 & $\mathrm{pCi} / \mathrm{g}$ & 0.84 & 1.69 \\
\hline Fine & QC Blank & Plutonium 239/240 & 0.15 & $\mathrm{pCi} / \mathrm{g}$ & 0.49 & 1.36 \\
\hline Fine & QC Blank & Americium 241 & 1.45 & $\mathrm{pCi} / \mathrm{g}$ & 2.2 & 4.47 \\
\hline Fine & QC Blank RE & Plutonium 238 & -0.2 & $\mathrm{pCi} / \mathrm{g}$ & 0.08 & .65 \\
\hline Fine & QC Blank RE & Plutonium 239/240 & -0.12 & $\mathrm{pCi} / \mathrm{g}$ & 0.06 & \\
\hline Fine & QC Blank RE & Americium 241 & 0.92 & $\mathrm{pCi} / \mathrm{g}$ & 1.01 & 1.69 \\
\hline Fine & QCLCS & Plutonium 238 & 86 & $\%$ recovery & & \\
\hline Fine & QCLCS & Plutonium $239 / 240$ & 95 & $\%$ recovery & & \\
\hline Fine & QCLCS & Americium 241 & 125 & $\%$ recovery & & \\
\hline Fine & QCLCS RE & Plutonium 238 & 82 & $\%$ recovery & & \\
\hline Fine & QCLCS RE & Plutonium $239 / 240$ & 100 & $\%$ recovery & & \\
\hline Fine & QCLCS RE & Americium 241 & 85 & $\%$ recovery & & \\
\hline
\end{tabular}


Appendix G

Passive Alpha Detector Data Summaries and Result Discussions 



\section{Memorandum}

Date:

$09 / 22 / 95$

To:

Richard McKinley, IT Las Vegas

From: $\quad$ Ken Sadler, IT Knoxville

Subject: $\quad$ Final Report : Treatability Testing on Double Tracks Soil (Project \# 301941.03030200)

\section{Introduction :}

On 7/28/95, ten soil samples were received from the IT Las Vegas office by the Technology Development Laboratory in Knoxville, Tn. for treatability testing. In order to provide a radiological baseline and to determine if any special handling requirements might be necessary, these samples were screened for Gross Alpha/Beta and Total Specific Activity The values are listed below:

$\begin{array}{cccc}\text { Sample \# } & \begin{array}{c}\text { Gross Alpha } \\ (\mu \mathrm{Ci} / \mathrm{g})\end{array} & \begin{array}{c}\text { Gross Beta } \\ (\mu \mathrm{Ci} / \mathrm{g})\end{array} & \begin{array}{c}\text { Total Specific Activity } \\ (\mu \mathrm{Ci} / \mathrm{g})\end{array} \\ \text { DT 725001A } & 5.95 \mathrm{E}-03 & 1.84 \mathrm{E}-04 & 6.13 \mathrm{E}-03 \\ \text { DT 725002A } & 2.27 \mathrm{E}-03 & 7.94 \mathrm{E}-05 & 2.35 \mathrm{E}-03 \\ \text { DT 725003A } & 3.78 \mathrm{E}-04 & 4.67 \mathrm{E}-05 & 4.25 \mathrm{E}-04 \\ \text { DT 725004A } & 3.51 \mathrm{E}-04 & 3.70 \mathrm{E}-05 & 3.88 \mathrm{E}-04 \\ \text { DT 725005A } & 4.29 \mathrm{E}-04 & 3.85 \mathrm{E}-05 & 4.67 \mathrm{E}-04 \\ \text { DT 725006A } & 2.64 \mathrm{E}-03 & 9.87 \mathrm{E}-05 & 2.74 \mathrm{E}-03 \\ \text { DT 725007A } & 2.30 \mathrm{E}-03 & 6.06 \mathrm{E}-05 & 2.36 \mathrm{E}-03 \\ \text { DT 725008A } & 1.90 \mathrm{E}-04 & 3.53 \mathrm{E}-05 & 2.25 \mathrm{E}-04 \\ \text { DT 725009A } & 1.99 \mathrm{E}-04 & 3.48 \mathrm{E}-05 & 2.34 \mathrm{E}-04 \\ \text { DT 725010A } & 2.29 \mathrm{E}-04 & 3.78 \mathrm{E}-05 & 2.67 \mathrm{E}-04\end{array}$

The purpose of this study was to evaluate the potential of a physical separation process to lower the radiological content of the soil. Physical separation techniques such as sieving and attrition scrubbing were tested in order to determine an efficient. simple. low cost remediation method. The contaminant plutonium 241 (Pu-241) was of primary concern. However, plutonium is a low gamma emitter. Therefore, americium 241 (Am-24l) which is present in a "known" activity ratio to the Pu-24l in the soil, was the contaminant analyzed for. The Am- 
241 is a gamma emitter which can be analyzed for by gamma spectroscopy, from which the Pu-24l activity can then be calculated. The treatability testing was broken into two separate phases, soil characterization and attrition scrubbing experiments.

\section{Technical Approach :}

\section{Experimental Design}

Soil Characterization - The characterization testing established the distribution of radiochemical contaminants in the individual size fractions. Each of the ten "as received" samples were separated into 4 different size fractions; an oversize debris fraction, a coarse sand, a fine sand, and a silt and clay fraction. Each of these fractions were to be analyzed for radiochemical content by gamma spectroscopy.

Attrition Scribbing - The objective of these experiments were to physically remove any radiochemical contamination that was loosely bound to the surface of the soil particles. This was accomplished by violent agitation of sand particles. These sand particles "hit and scraped" one another and forced the contaminants to tlake off into the fine fraction $(<\# 100$ mesh).

\section{Experimental Procedures \\ Soil Characterization}

Characterization testing was necessary to determine the distribution of contaminant in the various particle size fractions. The soil composite sample were divided into four size fractions using a Ro-Tap sieve shaker. The procedure is outlined in the IT "Draft" SOP Separaition of Soil Size lractions by Sicuing which is provided in Appendix A. All soil sieving procedures were a wet sieving process. The soil types were separated into a debris and gravel fraction ( $>4$ sieve removed prior to homogenization), a coarse sand fraction (\#4$\# 100$ sieve), a fine sand fraction $(\# 100-\# 200$ sieve), and a silt and clay fraction $(<\# 200$ sieve). Each of these fractions were originally to be analyzed for radiochemical content by gamma spectroscopy, however, only the $\$ 4-\$ 100$ mesh fraction contained enough material for this procedure. This testing was to establish the initial distribution of contaminant in the individual size fractions.

\section{Attrition Scmibbing}

Attrition scrubbing uses a single agitator with two oppositely pitched propellers. During operation, the top blade forces sample down and the bottom blade forces sample up, causing an attriting action of the soil particles with each other. Therefore, if any lead contamination is physically bound to the surface an individual particle, this violent agitation might remove the contaminant. Only coarse size fractions were tested for attrition scrubbing since fines tend to buffer or "cushion" the attriting action of the particles. Each \#4-\#100 sieve size fraction was tested at 15 minutes scrubbing time, with an approximate 75 percent solids ratio. This procedure is outlined in the IT "draft" SOP Rench-iciale Altrition Scmbbing provided in Appendix A. Following each attrition experiment, the samples were sieved into two size fractions, a coarse fraction $(>\neq 100$ mesh) and a fines fraction $(<\# 100 \mathrm{mesh})$. The coarse fractions were analyzed for radiochemical content by gamma spectroscopy. 


\section{Equipment and Materials}

Sieving Operations

A Ro-Tap Sieve Shaker, manufactured by W.S. Tyler, was used for all sieving operations.

This shaker is the standard machine for automatucally carrying out sieve test procedures with accuracy and dependability. It is designed to hold a series of 8-inch diameter sieves and imparts to the sieves both a circular and tapping motion. The speed and stroke are fixed, which ensures comparability between sieve tests. The Ro-Tap is equipped to handle from 1 to 13 sieves at a time and is equipped with a timer that will automatically terminate the test at any predetermined time. All sieves conformed to the requirements of ASTM E-11.

\section{A trition Scrubbing Operations}

A Denver Equipment Company, D-12 Laboratory Flotation/Attrition Machine was used for all attrition scrubbing operations. This machine converts to an attrition scrubber by inserting an opposed propeller of different blade pitch. This provides a maximum movement and rubbing of the mineral particles. An attrition tank is provided to prevent any spillage due to the violent agitation of the machine. High pulp densities of 70 to 75 percent solids at an approximate speed of $800 \mathrm{rpm}$ were used for efficient scrubbing.

\section{Results :}

\section{Soil Characterization}

The weight fractions from the sieving analysis are shown in Table \#1. Approximately 70 to 80 percent of each sample's mass is in the $\# 4-\# 100$ particle size fraction. From 5 to 10 percent is in the plus \#4 mesh, debris fraction; 10 to 20 percent is in the \#100-\#200 mesh, fine sand fraction; and 1 to 10 percent is in the minus $\# 200$ mesh, silt and clay fraction. Due to the small amount of material recovered in the plus \#4 mesh, the \#100-\#200 mesh, and the minus $\$ 200$ mesh fractions, only the $\# 4-\# 100$ mesh fractions were analyzed by gamma spectroscopy. A source with a different geometery for the gamma spectroscopy instrument was ordered to analyze these other size fractions. but due to the project time constraints, it was not received in time. The results of the $=4-\not 100$ fractions are shown in Table $\ddot{\#} 2$. The ten values for Am-241 range from $1.5 \mathrm{pCi} / \mathrm{s}$ to $19.7 \mathrm{pCi} / \mathrm{g}$ with an average value of 8.88 $\mathrm{pCi} / \mathrm{g}$.

\section{Attrition Scmubbing}

This fraction was then attritioned as described in the technical approach section. The attritioned samples were then re-sieved over a $\# 100$ mesh screen. The material balances for each sample is shown in Table \#3. This table illustrates how much "as received" material is minus $\# 100$ mesh after the first sieve separation, and then how much more material is forced into this fraction by attrition scrubbing. The attritioning forced approximately 12 to 36 percent more material to the fines fraction. The attritioned, plus $\# 100$ mesh samples were then re-analyzed by gamma spectroscopy. The results are shown in Table \#4. The values for Am-24l range from $0.7 \mathrm{pCi} / \mathrm{g}$ to $16 \mathrm{pCi} / \mathrm{g}$ with an average value $5.58 \mathrm{pCi} / \mathrm{g}$. Attritioning therefore removed an average of 37 percent of the Am-24I activity in this size fraction by forcing an average of 18.7 percent of the soil into the fines fraction. 
Table \#1

NTS soils : Percentage of Soil in Size Fractions

\begin{tabular}{|c|c|c|c|c|c|c|c|c|c|}
\hline $\begin{array}{l}\text { Client } \\
\text { Sample \# }\end{array}$ & $\begin{array}{c}\text { TDL } \\
\text { Sampie \# }\end{array}$ & $\begin{array}{c}\text { plus \#4 mesh } \\
\text { (g) }\end{array}$ & $\begin{array}{l}\text { Percent } \\
\text { of Total }\end{array}$ & $\begin{array}{c}\# 4-\# 100 \text { mesh } \\
\text { (g) }\end{array}$ & $\begin{array}{l}\text { Percent } \\
\text { of Total }\end{array}$ & $\begin{array}{c}\# 100 \cdot \# 200 \text { mesh } \\
\text { (g) }\end{array}$ & $\begin{array}{l}\text { Percent } \\
\text { of Total }\end{array}$ & $\begin{array}{c}\text { minus } \# 200 \text { mesh } \\
\text { (g) }\end{array}$ & $\begin{array}{l}\text { Percent } \\
\text { of Total }\end{array}$ \\
\hline DT $725001 \mathrm{~A}$ & GG6854 & 113.14 & 7.27 & 109594 & 70.45 & 20355 & 13.08 & 14308 & 9.20 \\
\hline DT $725002 \mathrm{~A}$ & GG6855 & 104.12 & 7.21 & 1097.56 & 75.96 & 156.41 & 10.82 & 86.84 & 6.01 \\
\hline DT 725003A & GG̣6856 & 180.23 & 12.67 & 1134.1 & 79.72 & 922 & 6.48 & 16.11 & 1.13 \\
\hline Dr $725004 A$ & GG6857 & 948 & 5.97 & 1308.2 & 82.41 & 147.91 & 9.32 & 3645 & 2.30 \\
\hline DT $725005 \mathrm{~A}$ & GG6858 & 84.92 & 6.01 & 1018.18 & 72.05 & 26918 & 19.05 & 40.91 & 2.89 \\
\hline DT $725006 \mathrm{~A}$ & GG6859 & 78.26 & 4.78 & 1182.2 & 72.22 & 310.79 & 18.99 & 656 & 4.01 \\
\hline DT 725007A & GG6860 & 95.56 & 6.97 & 934.08 & 68.11 & 206.37 & 15.05 & 13548 & 9.88 \\
\hline DT $725008 \mathrm{~A}$ & GG6861 & 165.24 & 10.55 & 126225 & 80.59 & 121.53 & 7.76 & 1723 & 1.10 \\
\hline DT $725009 \mathrm{~A}$ & GG6862 & 111.99 & 7.04 & 110372 & 69.42 & 3181 & 20.01 & 56.17 & 3.53 \\
\hline DT $725010 \mathrm{~A}$ & GG6863 & 8256 & 6.37 & 1186.28 & $\mathbf{9 1 . 5 0}$ & 22.26 & 1.72 & 5.45 & 0.42 \\
\hline
\end{tabular}


NTS - Site Soil

plus $\mathbf{1 0 0}$ mesh Size Fraction

Radiological Results

(Uncertainties reported as percent at 2-sigma)

\begin{tabular}{|c|c|c|c|c|c|c|c|c|c|c|c|}
\hline Nuclide (pCi/g) & MDA & SN-GG\#6854 & $\mathrm{a}$ & SN-GG\#6855 & $\mathbf{a}$ & SN-GG\#6856 & 0 & SN-GG\#6857 & 0 & SN-GG\#6858 & $\mathbf{a}$ \\
\hline$A c-228$ & 0.0320 & $1.5 \pm 10$ & & $1.6 \pm 10$ & & $1.4 \pm 10$ & & $1.4 \pm 10$ & & $1.5 \pm 11$ & \\
\hline Am-241 & 0.0102 & $17.0 \pm 1$ & & $5.12 \pm 2$ & & $2.4 \pm 6$ & & $16.2 \pm 1$ & & $1.5 \pm 7$ & \\
\hline$B i-214$ & 0.0070 & $0.96 \pm 10$ & & $1.1 \pm 8$ & & $1.1 \pm 8$ & & $1.1 \pm 8$ & & $1.0 \pm 8$ & \\
\hline Cs-137 & 0.00448 & $0.19 \pm 19$ & & $0.14 \pm 23$ & & $0.18 \pm 15$ & & $0.18 \pm 16$ & & $0.30 \pm 13$ & \\
\hline $\mathrm{K}-40$ & 0.035 & $27 \pm 6$ & & $28 \pm 6$ & & $28 \pm 6$ & & $25 \pm 6$ & & $27 \pm 6$ & \\
\hline $\mathrm{Np}-237$ & 0.0842 & 0.0842 & $\mathbf{U}$ & 0.0842 & $\mathbf{U}$ & 0.0842 & $\mathrm{U}$ & 0.0842 & $u$ & 0.0842 & $\mathrm{U}$ \\
\hline $\mathrm{Pb}-212$ & 0.0104 & $1.1 \pm 6$ & & $1.5 \pm 6$ & & $1.6 \pm 6$ & & $1.4 \pm 6$ & & $1.6 \pm 6$ & \\
\hline $\mathrm{Pb}-214$ & 0.0056 & $1.0 \pm 8$ & & $1.1 \pm 8$ & & $0.99 \pm 9$ & & $1.1 \pm 8$ & & $1.0 \pm 8$ & \\
\hline $\mathrm{Pu}-241$ & 4095 & 4095 & $U$ & 4095 & $\mathbf{u}$ & 4095 & $\mathrm{U}$ & 4095 & $\mathbf{U}$ & 4095 & $\mathrm{U}$ \\
\hline $\mathrm{Pu}-240$ & 61.9 & 61.9 & $\mathbf{U}$ & 61.9 & $\mathbf{U}$ & 61.9 & $\mathrm{U}$ & 61.9 & $\mathbf{U}$ & 61.9 & $\mathbf{U}$ \\
\hline $\mathrm{Pu}-239$ & 15.5 & 15.5 & $\mathbf{U}$ & 15.5 & $\mathbf{U}$ & 15.5 & $\mathrm{U}$ & 15.5 & $\mathbf{U}$ & 15.5 & $\mathbf{U}$ \\
\hline Th-228 & 0.911 & 0.911 & $\mathbf{U}$ & 0.911 & $\mathbf{U}$ & 0.911 & $\mathrm{U}$ & 0.911 & $\mathrm{U}$ & 0.911 & U \\
\hline Th-229 & 0.0066 & 0.0066 & $\mathbf{U}$ & 0.0066 & $\mathrm{U}$ & 0.0066 & $\mathrm{U}$ & 0.0066 & $-U$ & 0.0066 & U \\
\hline TI-208 & 0.0012 & $0.47 \pm 7$ & & $0.58 \pm 6$ & & $0.55 \pm 6$ & & $0.50 \pm 6$ & & $0.59 \pm 5$ & \\
\hline $\mathrm{Pa}-231$ & 0.245 & 0.245 & $\mathbf{U}$ & 0.245 & $\mathbf{u}$ & 0.245 & $\mathbf{U}$ & 0.245 & $\mathbf{u}$ & 0.245 & $\mathbf{U}$ \\
\hline U-235 & 0.0054 & 0.0054 & $\mathbf{U}$ & 0.0054 & $\mathbf{U}$ & 0.0054 & U & 0.0054 & $\bar{U}$ & 0.0054 & $\mathbf{U}$ \\
\hline
\end{tabular}




\section{TABLE 2}

NTS - Site Soil (cont.)

plus $\mathbf{1 0 0}$ mesh Size Fraction

Radiological Results

(Uncertainties reported as percent at 2-sigma)

\begin{tabular}{|c|c|c|c|c|c|c|c|c|c|c|c|}
\hline Nuclide (pCi/g) & MDA & SN-GG\#6859 & $\mathrm{a}$ & SN-GG\#6860 & $\mathrm{a}$ & SN-GG\#6861 & $\mathbf{0}$ & SN-GG\#6862 & $\mathbf{a}$ & SN-GG\#6863 & o \\
\hline $\mathrm{Ac}-228$ & 0.0320 & $1.5 \pm 11$ & & $1.4 \pm 11$ & & $1.4 \pm 9$ & & $1.4 \pm 9$ & & $1.4 \pm 11$ & \\
\hline Am-241 & 0.0102 & $10.9 \pm 4$ & & $19.7 \pm 1$ & & $1.91 \pm 4$ & & $6.7 \pm 2$ & & $7.4 \pm 4$ & \\
\hline $\mathrm{Bi}-214$ & 0.0070 & $1.0 \pm 9$ & & $1.1 \pm 8$ & & $0.92 \pm 8$ & & $0.94 \pm 8$ & & $1.1 \pm 8$ & \\
\hline Cs-137 & 0.00448 & $0.33 \pm 11$ & & $0.44 \pm 10$ & & 0.00448 & $\mathbf{U}$ & $0.1 \pm 24$ & & $0.26 \pm 14$ & \\
\hline $\mathrm{K}-40$ & 0.035 & $26 \pm 6$ & & $27 \pm 6$ & & $24 \pm 6$ & & $25 \pm 6$ & & $24 \pm 6$ & \\
\hline Np-237 & 0.0842 & 0.0842 & $\mathbf{U}$ & 0.0842 & $\mathrm{U}$ & 0.0842 & $\mathrm{U}$ & 0.0842 & $\mathrm{U}$ & 0.0842 & $\mathrm{U}$ \\
\hline $\mathrm{Pb}-212$ & 0.0104 & $1.4 \pm 6$ & & $1.4 \pm 6$ & & $1.4 \pm 6$ & & $1.4 \pm 6$ & & $1.5 \pm 6$ & \\
\hline $\mathrm{Pb}-214$ & 0.0056 & $1.0 \pm 8$ & & $1.1 \pm 8$ & & $1.0 \pm 8$ & & $1.1 \pm 8$ & & $1.1 \pm 8$ & \\
\hline $\mathrm{Pu}-241$ & 4095 & 4095 & $\mathrm{U}$ & 4095 & $\underline{u}$ & 4095 & $\mathbf{U}$ & 4095 & $\mathrm{U}$ & 4095 & $\mathbf{U}$ \\
\hline $\mathrm{Pu}-240$ & 61.9 & 61.9 & $U$ & 61.9 & $\bar{U}$ & 61.9 & $U$ & 61.9 & $U$ & 61.9 & $\mathrm{U}$ \\
\hline $\mathrm{Pu}-239$ & 15.5 & 15.5 & $\mathbf{U}$ & 15.5 & $\underline{U}$ & 15.5 & $\mathbf{U}$ & 15.5 & $U$ & 15.5 & U \\
\hline Th-228 & 0.911 & 0.911 & U & 0.911 & $\underline{U}$ & 0.911 & $\mathbf{U}$ & 0.911 & $\mathrm{U}$ & 0.911 & $\mathbf{U}$ \\
\hline Th-229 & 0.0066 & 0.0066 & $\mathrm{U}$ & 0.0066 & $\mathrm{U}$ & 0.0066 & $\mathbf{U}$ & 0.0066 & $U$ & 0.0066 & $\mathbf{U}$ \\
\hline TI-208 & 0.0012 & $0.53 \pm 6$ & & $0.53 \pm 6$ & & $0.44 \pm 6$ & & $0.49 \pm 6$ & & $0.46 \pm 7$ & \\
\hline Pa-231 & 0.245 & 0.245 & $\mathrm{U}$ & 0.245 & $\mathbf{U}$ & 0.245 & $\bar{U}$ & 0.245 & $\mathbf{U}$ & 0.245 & $\mathbf{U}$ \\
\hline U-235 & 0.0054 & 0.0054 & $\mathrm{U}$ & 0.0054 & $\mathbf{U}$ & 0.0054 & $\mathbf{U}$ & 0.0054 & $\mathbf{U}$ & 0.0054 & $\bar{U}$ \\
\hline
\end{tabular}




\section{Table \#3}

\section{NTS soils : Percentage of Soil in Size Fractions}

$\begin{array}{ccc}\begin{array}{c}\text { Client } \\ \text { Sample \# }\end{array} & \begin{array}{c}\text { TDL } \\ \text { Sample \# }\end{array} \\ \text { DT 725001A } & \text { GG6854 } \\ \text { DT 725002A } & \text { GG6855 } \\ \text { DT 725003A } & \text { GG6856 } \\ \text { DT 725004A } & \text { GG6857 } \\ \text { DT 725005A } & \text { GG6858 } \\ \text { DT 725006A } & \text { GG6859 } \\ \text { DT 725007A } & \text { GG6860 } \\ \text { DT 725008A } & \text { GG6861 } \\ \text { DT 725009A } & \text { GG6862 } \\ \text { DT 725010A } & \text { GG6863 }\end{array}$

\author{
"As Received" Soil \\ Wet-sieved (\#100 mesh)
}

\section{Percent}

of Total

Plus \#100 mesh

Percent of Total

Minus \#100 Mesh

77.72
83.17
92.39
88.39
78.06
77.01
75.07
91.14
76.46
97.86

22.28

16.83

7.61

11.61

21.94

22.99

24.93

8.86

23.54

2.14
Wet-Sieved, Plus \#100 Mesh, Attritioned, Re-sieved (\#100 Mesh)

\section{Percent}

of Total
Plus $\$ 100$ mesh

Percent

of Total

Plus \#100 mesh Minus \#100 Mesh

\begin{tabular}{l}
64.91 \\
70.25 \\
76.58 \\
61.70 \\
57.32 \\
62.47 \\
60.95 \\
75.65 \\
\hline 59.39 \\
61.34
\end{tabular}

12.81

12.92

15.81

26.69

20.74

14.54

14.12

15.49

17.07

36.52 


\begin{tabular}{|c|c|c|c|c|c|c|c|c|c|c|c|c|}
\hline & $6 \varepsilon \mp 91^{\circ} 0$ & $n$ & $t 900.0$ & $\geq$ & & $Z \varepsilon \mp 91^{\circ} 0$ & & $6 Z \mp \varepsilon \tau 0$ & $n$ & $\nabla 9000$ & $t 900^{\circ} 0$ & $9 \varepsilon z-n$ \\
\hline \multirow[t]{2}{*}{$\mathbf{n}$} & St20 & $n$ & 9720 & $\geq$ & $n$ & 9020 & $n$ & $9 t 20$ & $n$ & 9720 & $9+20$ & lEz-ed \\
\hline & $\angle 1 \mp 89^{\circ} 0$ & & $11 \mp \angle 90$ & & & ZLF $89^{\circ} 0$ & & $11 \mp \varepsilon 9^{\circ} 0$ & & $21 \mp 80^{\circ} 0$ & 21000 & $802-11$ \\
\hline$n$ & 9900.0 & $n$ & 99000 & $\Sigma$ & $n$ & 99000 & $\mathrm{n}$ & 99000 & $\bar{n}$ & 9900.0 & 99000 & $622-41$ \\
\hline$n$ & 1160 & $n$ & 1160 & $\Sigma$ & $\mathrm{n}$ & $116^{\circ} 0$ & $n$ & 1160 & $n$ & 1160 & 1160 & $822-41$ \\
\hline$n$ & 9.91 & $n$ & G' $9 l$ & $\geq$ & $n$ & 991 & $n$ & G.9l & & $G L \mp 86 t$ & $9 \cdot 91$ & $6 \varepsilon z-n_{d}$ \\
\hline$n$ & 6.19 & $n$ & 619 & $\geq$ & $n$ & 6.19 & $n$ & $6 \cdot 19$ & $n$ & 6.19 & 6.19 & $0 \nabla z-n_{d}$ \\
\hline \multirow[t]{3}{*}{ n } & 960t & $n$ & $960 t$ & $\Sigma$ & $n$ & $960 t$ & $n$ & 960t & $n$ & $960 t$ & $960 t$ & $10 z-n_{d}$ \\
\hline & $\varepsilon L \mp \varepsilon^{\prime} l$ & & $21 \mp \varepsilon l$ & & & $\varepsilon 1 \mp \varepsilon l$ & & Zl干 $\varepsilon^{\prime} l$ & & Gl $\mp 1 \cdot 1$ & 9900.0 & $\underline{t 2-9 d}$ \\
\hline & $8 \mp 81$ & & $6 \mp \angle 1$ & & & $6 \mp 81$ & & $6 \mp \angle 1$ & & $6 \mp \varepsilon 1$ & $7010^{\circ} 0$ & $212-9 d$ \\
\hline \multirow[t]{6}{*}{$n$} & $2+80^{\circ} 0$ & $n$ & $2+80^{\circ} 0$ & $\geq$ & $n$ & $\tau \gg 80^{\circ} 0$ & $n$ & $2 \$ 80^{\circ} 0$ & $n$ & $2+80^{\circ} 0$ & $2080^{\circ} 0$ & $\angle E Z-d N$ \\
\hline & $8 \mp \varepsilon \varepsilon$ & & $8 \mp \varepsilon \varepsilon$ & & & $8 \mp \varepsilon \varepsilon$ & & $8 \mp 2 \varepsilon$ & & $6 \mp 81$ & $980^{\circ} 0$ & $0 t-x$ \\
\hline & $2 \varepsilon \mp 920$ & $n$ & 806000 & $\Sigma$ & & $\angle t \mp 910$ & $n$ & 806000 & & Gl $\mp 090$ & 860000 & $\angle \varepsilon l-s]$ \\
\hline & El $\mp t l$ & & $\varepsilon \downarrow \mp \varepsilon l$ & & & $\varepsilon l \mp Z l$ & & $\varepsilon l \mp Z l$ & & $\varepsilon l \mp l \cdot l$ & $0 \angle 000$ & $012-18$ \\
\hline & $9 \mp 28$ & & $9 \mp t 9$ & & & $8 \mp 9: 2$ & & $9 \mp 9 \cdot 9$ & & $\nabla \mp 0 \varepsilon$ & 20100 & $1 \nabla z-w \forall$ \\
\hline & $\angle L \mp \angle L$ & & $12 \mp \angle 1$ & & & $81 \mp 91$ & & $81 \mp 91$ & & $81 \mp 61$ & OZEO० & $822-0 \forall$ \\
\hline 0 & V8989\#55-NS & 0 & $\forall \angle G 89 \# 59-N S$ & & 0 & $\forall 9989$ \#99-NS & 0 & $\forall G 989 \# 95$ NS & o & $\forall t G 89 \# 99-N S$ & $\forall 0 w$ & $\left(6 / !{ }^{d}\right)$ әp!!JnN \\
\hline
\end{tabular}

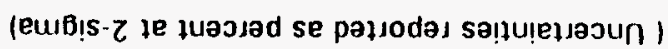

słnsəy jeग!60|일y

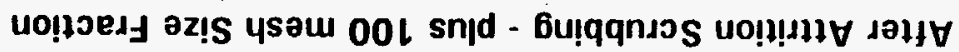

I!OS o!!S - SIN

เ $378 \forall 1$ 
NTS - Site Soil (cont.)

After Attrition Scrubbing - plus 100 mesh Size Fraction

Radiological Results

(Uncertainties reported as percent at 2-sigma)

\begin{tabular}{|c|c|c|c|c|c|c|c|c|c|c|c|}
\hline Nuclide $(p \mathrm{Ci} / \mathrm{g})$ & MDA & SN-GG\#6859A & $\mathbf{a}$ & SN-GG\#6860A & Q & SN-GG\#6861A & $\mathbf{Q}$ & SN-GG\#6862A & 0 & SN-GG\#6863A & 0 \\
\hline Ac-228 & 0.0320 & $1.7 \pm 17$ & & $1.7 \pm 16$ & & $1.5 \pm 18$ & & $1.6 \pm 21$ & & $1.5 \pm 20$ & \\
\hline$A m-241$ & 0.0102 & $6.6 \pm 6$ & & $16 \pm 4$ & & $0.7 \pm 20$ & & $4.9 \pm 6$ & & $0.9 \pm 24$ & \\
\hline$B i-214$ & 0.0070 & $1.2 \pm 13$ & & $1.1 \pm 16$ & & $1.3 \pm 13$ & & $1.1 \pm 16$ & & $1.2 \pm 14$ & \\
\hline Cs-137 & 0.00448 & $0.25 \pm 31$ & & $0.33 \pm 24$ & & 0.00448 & $\mathbf{U}$ & 0.00448 & $\mathrm{U}$ & $0.17 \pm 53$ & \\
\hline $\mathrm{K}-40$ & 0.035 & $30 \pm 8$ & & $33 \pm 8$ & & $30 \pm 8$ & & $30 \pm 8$ & & $32 \pm 8$ & \\
\hline Np-237 & 0.0842 & 0.0842 & $\mathrm{U}$ & 0.0842 & $\mathrm{U}$ & 0.0842 & $\mathrm{U}$ & 0.0842 & $\mathrm{U}$ & 0.0842 & $\bar{U}$ \\
\hline $\mathrm{Pb}-212$ & 0.0104 & $1.6 \pm 9$ & & $1.7 \pm 9$ & & $1.8 \pm 8$ & & $1.7 \pm 9$ & & $1.6 \pm 9$ & \\
\hline $\mathrm{Pb}-214$ & 0.0056 & $1.2 \pm 12$ & & $1.2 \pm 14$ & & $1.2 \pm 13$ & & $1.2 \pm 13$ & & $1.2 \pm 12$ & \\
\hline Pu-241 & 4095 & 4095 & $\mathrm{U}$ & 4095 & $\mathrm{U}$ & 4095 & $\mathbf{U}$ & 4095 & $\underline{U}$ & 4095 & $\mathrm{U}$ \\
\hline Pu-240 & 61.9 & 61.9 & $U$ & 61.9 & 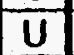 & 61.9 & $\mathrm{U}$ & 61.9 & $\mathbf{U}$ & 61.9 & $\bar{U}$ \\
\hline $\mathrm{Pu}-239$ & 15.5 & 15.5 & U & 15.5 & $\mathrm{U}$ & 15.5 & $\mathrm{U}$ & 15.5 & $\mathrm{U}$ & 15.5 & $\mathrm{U}$ \\
\hline Th-228 & 0.911 & 0.911 & $\mathrm{U}$ & 0.911 & $\mathrm{u}$ & 0.911 & $U$ & 0.911 & $\mathbf{U}$ & 0.911 & $\bar{U}$ \\
\hline Th-229 & 0.0066 & 0.0066 & $\mathrm{U}$ & 0.0066 & $\mathrm{U}$ & 0.0066 & $u$ & 0.0066 & $\mathbf{U}$ & 0.0066 & $\mathbf{U}$ \\
\hline TI-208 & 0.0012 & $0.49 \pm 17$ & & $0.56 \pm 14$ & & $0.64 \pm 11$ & & $0.53 \pm 12$ & & $0.59 \pm 13$ & \\
\hline $\mathrm{Pa}-231$ & 0.245 & 0.245 & $\bar{U}$ & 0.245 & $U$ & 0.245 & $U$ & 0.245 & $\mathbf{U}$ & 0.245 & $\bar{U}$ \\
\hline $\mathrm{U}-235$ & 0.0054 & 0.0054 & $\mathrm{U}$ & $<0.15 \pm 33$ & U & 0.0054 & $\mathbf{u}$ & 0.0054 & $\bar{U}$ & 0.0054 & $\mathrm{U}$ \\
\hline
\end{tabular}


The fines fractions (the $=100-\# 200$ mesh, and the minus $=200$ mesh fractions) from the soil characterization were small percentages of the total. Therefore. these were combined with the fines produced from attrition scrubbing for each of the ten samples. These samples were then sent to the Quanterra Laboratory in St. Louis for analysis. These results will be used to provide a mass balance for the contaminants in order to complete the engineering assessment. The attritioned, plus $\# 100$ mesh samples were also sent to this laboratory for verification of the treatability test results.

\section{Conclusions}

The results of the soil characterization clearly show that the plus \#100 mesh material contains the bulk of the total soil for each sample. An average of the ten samples show 83.7 percent of the total "as received". mass is plus $\# 100$ mesh $(150 \mu \mathrm{m})$. The attrition scrubbing results looked promising. Approximately 37 percent of the Am-24l activity in this size fraction was removed by forcing an average of 18.7 percent of the soil into the fines fraction. Out of the ten samples, seven had a sizable decrease in Am-24l activity after attritioning, two remained about the same, and one sample showed an increase. The percent removals for each sample is shown below:

$$
\text { Sample \# }
$$

DT $725001 \mathrm{~A}$

DT $725002 \mathrm{~A}$

DT $725003 \mathrm{~A}$

DT $725004 \mathrm{~A}$

DT $725005 \mathrm{~A}$

DT $725006 \mathrm{~A}$

DT $725007 \mathrm{~A}$

DT $725008 \mathrm{~A}$

DT $725009 \mathrm{~A}$

DT $725010 \mathrm{~A}$

\section{Percent Removal}

$$
\begin{array}{r}
6.7 \% \\
-27.0 \% \\
-8.3 \% \\
60.5 \% \\
-447 \% \\
39.4 \% \\
19.1 \% \\
63.4 \% \\
26.9 \% \\
87.8 \%
\end{array}
$$

The results for Samples DT 725002A, Dt 725003A, and DT 725005A should be discounted since the starting vallues were so low to begin with (less than $5 \mathrm{pCi} / \mathrm{g}$ ). Therefore the attrition results do appear to be successful. However, once the results of the fines fractions are received from Quanterra, the benefits of sieving and attritioning can be more accurately assessed. 


\section{Distribution List}

\section{Copies}

DOE/Nevada Operations Office

Technical Information Resource Center

P.O. Box 98518

Las Vegas, Nevada 89193-8518

U.S. Department of Energy

Office of Scientific and Technical Information

175 Oak Ridge Turnpike

Post Office Box 62

Oak Ridge, Tennessee 37831 


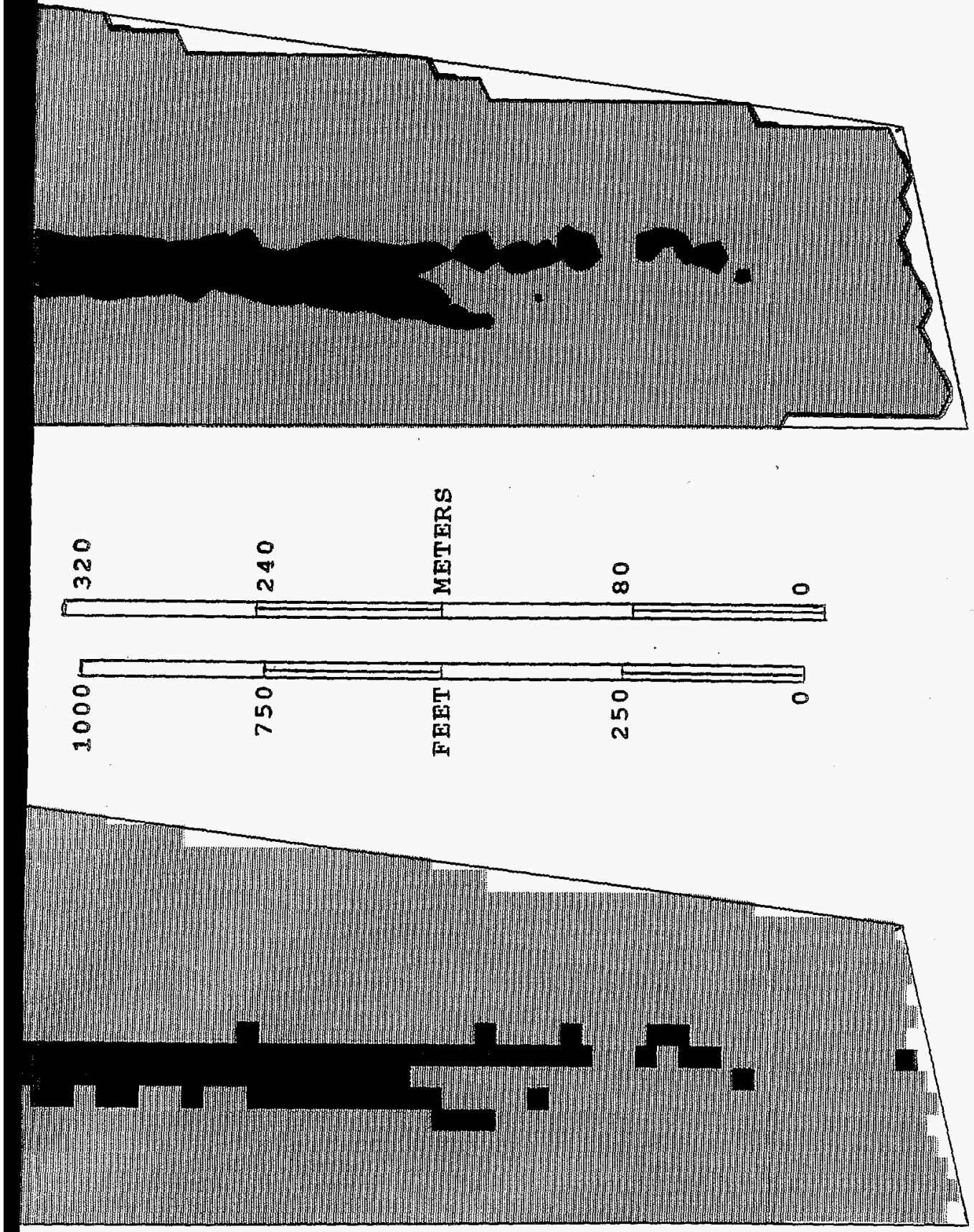

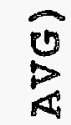

皆

100000000

ro 0000000

$\alpha 00$ or 0 H

a $\mathrm{H} N \mathrm{~N} N \mathrm{~N}, \mathrm{~m}$

A.

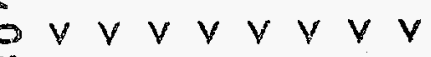

$0 \mathrm{~m}$

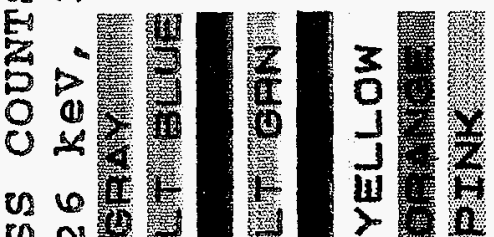

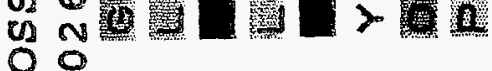

O O $\mathrm{O} \vee \vee \vee \vee V \vee V \vee$

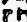

II 0000000

000000000

W0 00000000

8

क $\alpha$ r $\rightarrow \sim N M$

过

$02 \mathrm{ES}$

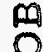

0

4

$\infty$ 

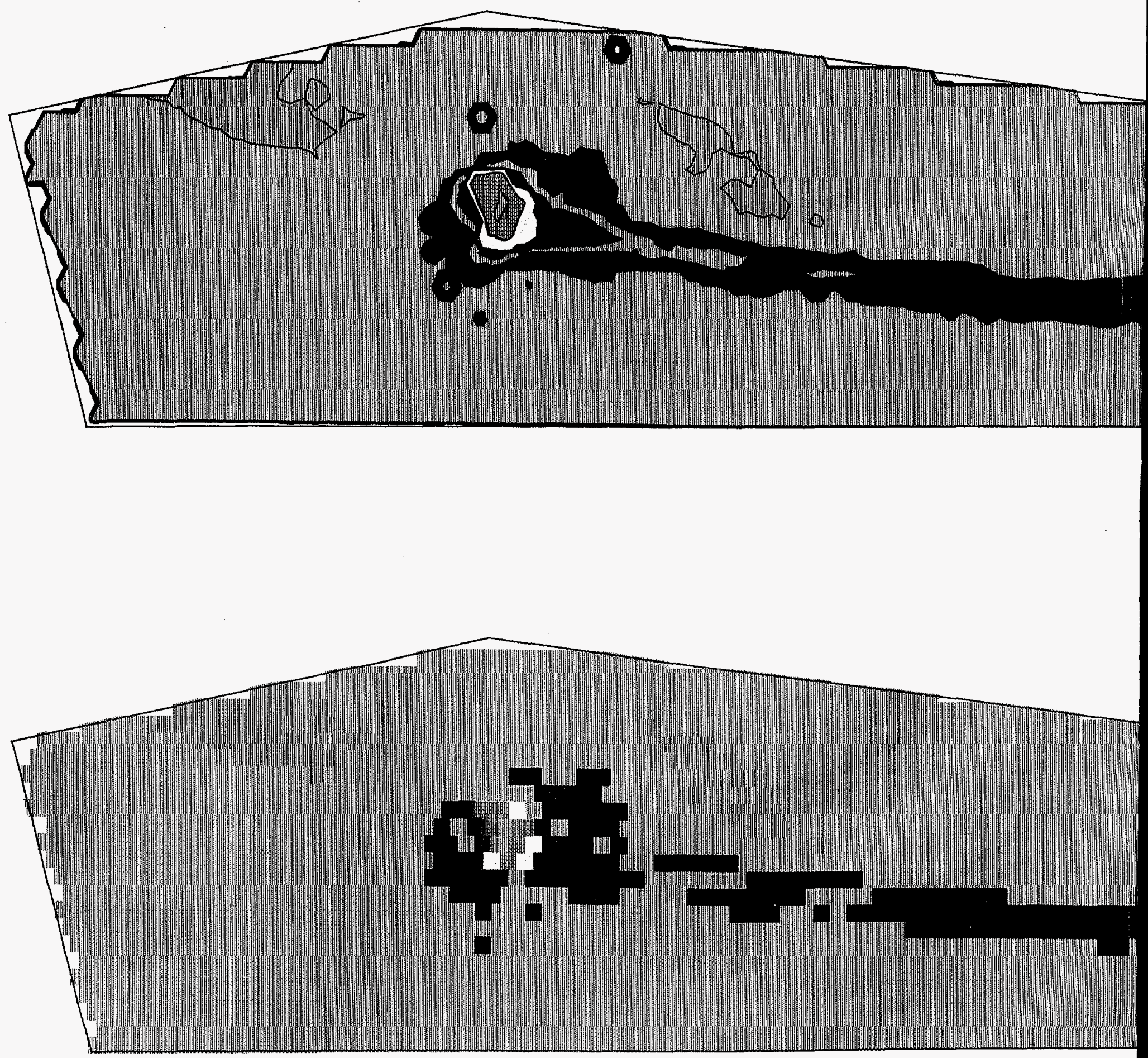

FIGURE 11. KIWI 30-FT GRIDDED AND 30-FT AVERAGED GROSS COUNT DATA. The observed gross count of all gamma rays in the individual Kiwispectra were collected into a 30 -ft grid and averaged over one grid cell. Since the survey area is relatively small, the gross count rate is relatively constant, except in the heavily contaminated areas. The data are presented both as squares centered on the grid loci and as contour levels derived from the gridded data. 